\title{
De rechtspositie van de architect 1850-1985 : een onderzoek naar de relatie tussen ontwikkelingen in de maatschappelijke positie en rechtspositie
}

Citation for published version (APA):

Fontein, E. M. (1988). De rechtspositie van de architect 1850-1985: een onderzoek naar de relatie tussen ontwikkelingen in de maatschappelijke positie en rechtspositie. [Doctoral Thesis, Maastricht University]. Delftse Universitaire Pers. https://doi.org/10.26481/dis.19881007ef

Document status and date:

Published: 01/01/1988

DOI:

10.26481/dis.19881007ef

Document Version:

Publisher's PDF, also known as Version of record

Please check the document version of this publication:

- A submitted manuscript is the version of the article upon submission and before peer-review. There can be important differences between the submitted version and the official published version of record.

People interested in the research are advised to contact the author for the final version of the publication, or visit the DOI to the publisher's website.

- The final author version and the galley proof are versions of the publication after peer review.

- The final published version features the final layout of the paper including the volume, issue and page numbers.

Link to publication

\footnotetext{
General rights rights.

- You may freely distribute the URL identifying the publication in the public portal. please follow below link for the End User Agreement:

www.umlib.nl/taverne-license

Take down policy

If you believe that this document breaches copyright please contact us at:

repository@maastrichtuniversity.nl

providing details and we will investigate your claim.
}

Copyright and moral rights for the publications made accessible in the public portal are retained by the authors and/or other copyright owners and it is a condition of accessing publications that users recognise and abide by the legal requirements associated with these

- Users may download and print one copy of any publication from the public portal for the purpose of private study or research.

- You may not further distribute the material or use it for any profit-making activity or commercial gain

If the publication is distributed under the terms of Article 25fa of the Dutch Copyright Act, indicated by the "Taverne" license above, 
De rechtspositie van de architect 1850 - 1985 


\section{De rechtspositie van de architect $1850-1985$}

\section{EEN ONDERZOEK NAAR DE RELATIE TUSSEN ONTWIKKELINGEN IN DE MAATSCHAPPELIJKE POSITIE EN RECHTSPOSITIE}

Proefschrift ter verkrijging van de graad van doctor aan de Rijksuniversiteit Limburg te Maastricht, op gezag van de Rector Magnificus,

Prof. Dr. F.I.M. Bonke, volgens besluit van het College van Decanen, in het openbaar te verdedigen op

vrijjdag 7 oktober 1988 om 16.00 uur door:

ERIC MAARTEN FONTEIN

geboren te Amsterdam op 18 juni 1932.

Promotor: Prof. Mr. C.A. Adriaansens 
Copyright (C) 1988 by E.M. Fontein

No part of this book may be reproduced in any form by print, photoprint, microfilm or any other means, without written permission from Delft University Press. 
CURRICULUM VITAE

DANKBETUIGING $\quad 10$

AEKORTINGEN 11

I

INLEIDING

14

I.1 Uitgangspunten van het onderzoek

I.1.2 methoden van onderzoek 15

I.1.3 tijdvak van onderzoek 17

I. 2 Historische ontwikkelingen van de aannemer en de architekt tot ca. 1850

I.2.1 het aarzelend begin 18

I.2.2 het ontstaan en de ondergang van de gilden 19

I.2.3 het verschijnsel aanneming van werk/aannemer 20

I.2.4 het ontstaan van de standaardvoorwarden bij aanneming van bouwwerken 22

I.2.5 van bouwmeester tot architekt 23

I.3 Het rechtskarakter van de overeenkomst tussen de architekt en de opdrachtgever 25

I.3.1 algemeen 25

I.3.2 de ontwerp-opdracht an de architekt 25

I.4 Samenvatting 29

I.5 Notenlijst 30

II DE ONTWIKKELING VAN DE MAATSCHAPPELIJKE POSITIE VAN ARCHITERT EN AANNEMER TUSSEN 1850 EN 1940

II.1 De architekt

II.1.1 de architekt en de bescherming van zijn titel en beroep

I.1.2 de opleiding voor het architektenberoep 39

II.1.3 de architekt in organisatorisch verband 42

II.2 De aannemer 43

II.2.1 de annemersstand 43

II.2.2 eigenbouw en revolutiebouw

II.2.3 de ontwikkeling van het bouwbedrijf rond 193047

II.3 De opdrachtgever 48

II.4 Samenvatting 49

II.5 Notenlijst 50

III ONTWIKKELINGEN VAN DE RECHTSPOSITIE VAN DE

ARCHITEKT TEN OPZICHTE VAN AANNEMER EN

OPDRACHTGEVER TUSSEN $1850 \quad$ EN 1940

III.1 Inleiding 52

III.2 de rechtsverhouding architekt-principaal 53

III.2.1 de ontwikkeling van de kontraktuele relatie 53

III.2.1. Ihet rechtskarakter van de opdracht 63

III.2.1.2de vertegenwoordigingsbevoegdheid van de 
III.3 De buitenkontraktuele rechtspositie van de archit tekt

III.3.1 de architekt en de onrechtmatige daad
III.3.2 het auteursrecht met betrekking tot de bouwkunet.

III.3.3 titel- en beroepsbescherming 74

III.4 De rechtspositie van de annemer en zijn

III.4.2 de rechtsongelijkheid van opdrachtgever en aannemer rond $1900 \quad 75$

III.4.3 architekten tellen de misstanden aan de kaak 75

III.4.4 de rechtsverhouding opdrachtgever - aannemer nader overwogen $\quad 81$

III.4.5 de Raad van Arbitrage ingesteld 82

II.4.6 nieuwe bedreiging voor de annemer;hulp aan
derden

III.4.7 de besteksbepalingen van de architekt en het

III.4.8 de koncept-AAV 1911 van architekten, ingenieurs en aannemers 91

III.5 De aannemer als opdrachtgever van de architekt 92

II.6 Samenvatting 95

III.7 Notenlijst 97

IV DE ARCHITEKT IN HET MAATSCHAPPELIJK KRACHTENSPEL 1945-1.985 99

IV.1 Het bouwekonomisch beeld tussen 1945 en 1985100

IV.1.1 1945-1955 het algemeen ekonomisch herstel 100

$\begin{array}{lll}\text { IV.1.2 } 1955-1972 \text { de groei } & 102\end{array}$

IV.1.3 1972-1985 de kentering 106

IV.2 De matschappelijke plaatsbepaling van de architekt in zijn verhouding tot de opdrachtgever

IV $.2 \cdot 1$
IV $.2 \cdot 1.1$

1945-1955 de wederopbouw

108

108

de architekt nog een

matschappelijk middelpunt? 108

IV. $2 \cdot 1 \cdot 2$

de diskussie rond de ontwerp-

architektenwet van $1949 \quad 111$

IV.2.2 1955-1972 de hoogkonjunktuur 117

IV.2.3 1972-1985 de architekt in een krisissituatie 134

IV.2.4 het verschijnsel deelopdrachten 169

IV.2.5 na $1985 \quad 176$

IV.3 De opleiding tot architekt 178

IV.4 Samenvatting 183

IV.5 Notenlijst 185 
blz.

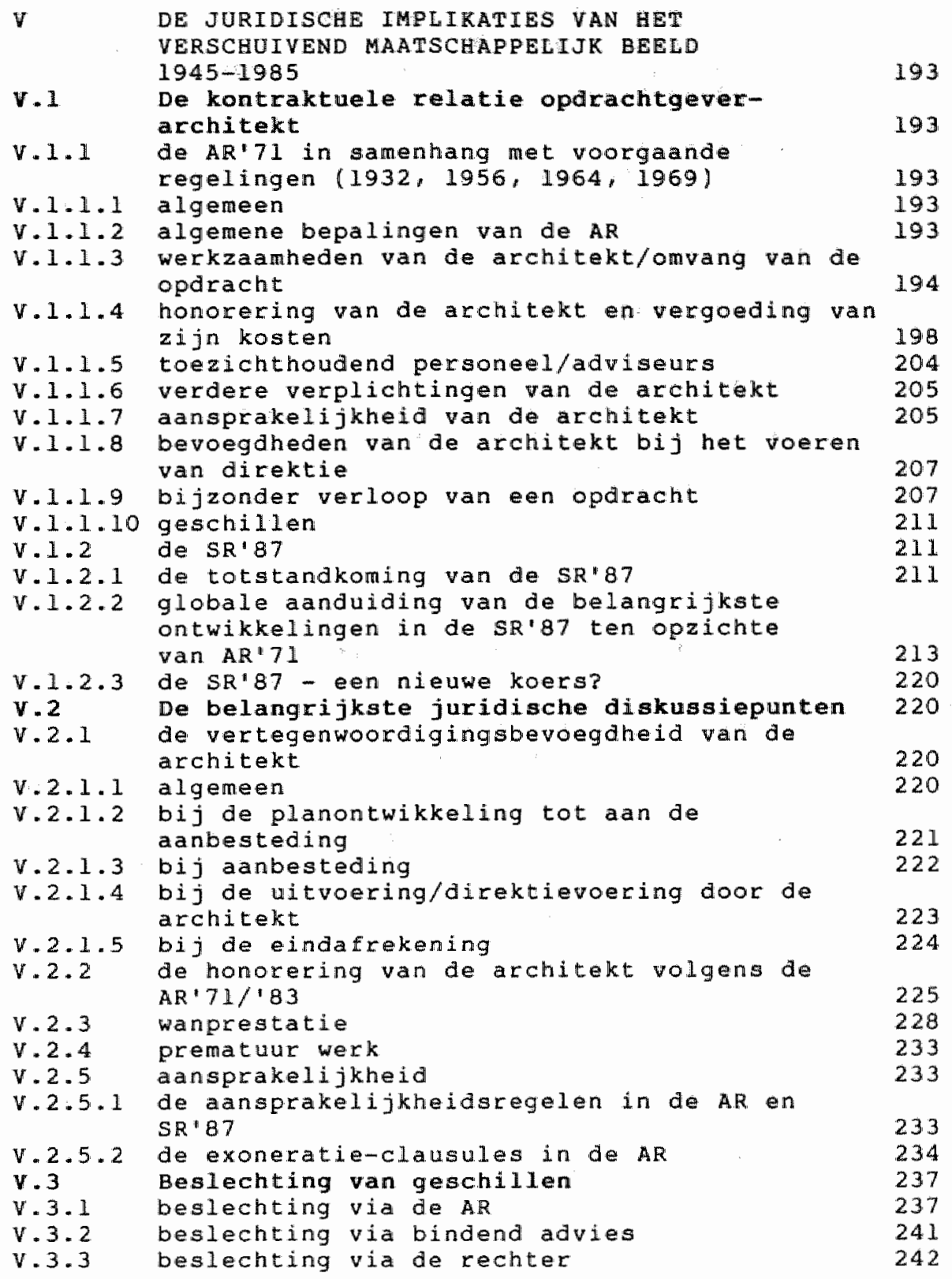


V.4 Praktijkontwikkelingen rond 1987

V.4.1 de opdracht in het NBW 244

V.4.2 scheidalijnen in de planontwikkelingsfasen 246

$v_{.4 .2 .1}$ de opdrachtglever 246

$\begin{array}{lll}V .4 .2 .2 & \text { de architekt } & 247\end{array}$

V.4.2.3 de opdracht : 249

V.4.3 koncentraties van partijen in de ontwerpfase 253

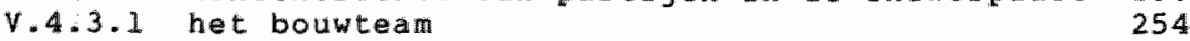

$V .4 .3 .2$ het ontwerpteam 255

v.4.3.3 de ontwerper als kontraktpartij van de

V. 5

aannemer

257

Samenvatting 258

v.6 Notenlijst

260

VI

VI. 1

AUTEURSRECHT EN DE BOUWKUNST

261

VI. 2

Korte historie van de wetgeving op het

auteursrecht met betrekking tot de Bouwkunst 262

VI. 3

De architekt en de Auteurswet 1912

26.7

VI. $3 \cdot 1$

De juridische definitie van de Auteurswet

1912 met betrekking tot de Bouwkunst

268

de ard van het auteursrecht

268

de maker van het werk

VI. 3.2

werken warop auteursicht bestaat

269

VI. $3 \cdot 3$

het openbaar maken en verveelvoudigen

271

VI. 3.4

VI. 4

VI. 4.1

Overige bepalingen van de Auteurswet

272

274

openbaarmaking en verveelvoudiging 274

VI. 4.2

beperkingen

274

VI. $4 \cdot 3$

het "droit-moral" of persoonlijkheidsrecht

274

VI.4.4 handhaving van het auteursrecht-

strafbepalingen

276

VI.4.5 duur van het auteursecht

VI.5 Het auteursrecht en de Algemene Regelen voor

de honorering van de architekt en de verdere rechtsverhouding tussen opdrachtgever en

architekt (AR'7I), C.g. SR'87

VI. 6

Notenlijst

$V I I$

KONKLUSIE

LITERATUURLIJST 285

$\begin{array}{ll}\text { VERKORTE INHOUD } & 287\end{array}$

SUMMARY

295 
CURRI CULUM VITAE.

Eric Marten Fontein, geboren 18 juni 1932 te Amsterdam

Lagere School te Amsterdam

$1938-1945$

HBS-b te Amsterdam en Delft

$1946-1951$

Technische Hogeschool te Delft

afd. Bouwkunde (utiliteitsbouw)

$1953-1961$

Vrije Universiteit te Amsterdam

Fakulteit der Rechtsgeleerdheid

$1981-1984$

Technische Universiteit te Delft

afd. Bouwrecht, Promotie-onderzoek

$1983-1985$

Rijksuniversiteit Limburg

Fakulteit der Rechtsgeleerdheid

vervolg Promotie-onderzoek.

$1985-1988$ 
Bij het werken aan dit proefschrift heb ik van zeer velen grote steun ondervonden, warvoor ik dank verschuldigd ben.

Dat geldt in de eerste plaats uiteraard voor mijn promotor PROF. MR. C.A. ADRIARSENS. De herlezing van de met hem gevoerde karrespondentie heeft mij opnieuw doen beseffen welk een tijabeslag de begeleiding van een promovendus vereist.

Aan de mandelijkse gesprekken met hem, warin hij mijmet raad en daad terzijde stond, bewar ik de beste herinnexingen.

zonder aan de overigen iets te kort te willen doen zou ik met name MR. H.C. WESSELING willen bedanken voor zijn opbouwende kritiek.

Zijn grote belangstelling voor de bouwkunst en de juridische kant van het bouwen, gepard gaande aan zijn langdurige ervaring als jurist, is voor mij van grote warde geweest.

Voor de bereidwilligheid van wijlen PROF. MR. C.M. STRAVER om een groot deel van zijn eigenhandig bijeengebrachte gegevens ter beschikking te stellen voor mijn onderzoek ben ik hem zeer erkentelijk. Zijn anwijzingen heb ik gaarne gevolgd.

Als "her-intreder" op latere leeftijd in de universitaire wereld is het mij opgevallen met hoeveel welwillendheid zij die aan de, meest wetenschappelijke, instituten $z i j n$ verbonden mij $z i j n$ tegemoet getreden.

Van deze instituten wil ik garne noemen:

- de Fakulteit der Rechtsgeleerdheid van de Wrije Universiteit te Amsterdam.

Naast de juridische scholing die ik aldaar mocht ontvangen, heb ik veel hulp mogen ondervinden van de fakulteits-bibliotheek.

- de Technische Universiteit te Delft.

- het Nederlands Dokumentatiecentrum voor de Bouwkunst

- de Koninklijke Blbliotheek te 's-Gravenhage.

- de Koninklijke Maatschappij tot Bevordering der Bouwkunst/BNA te Amsterdam. 


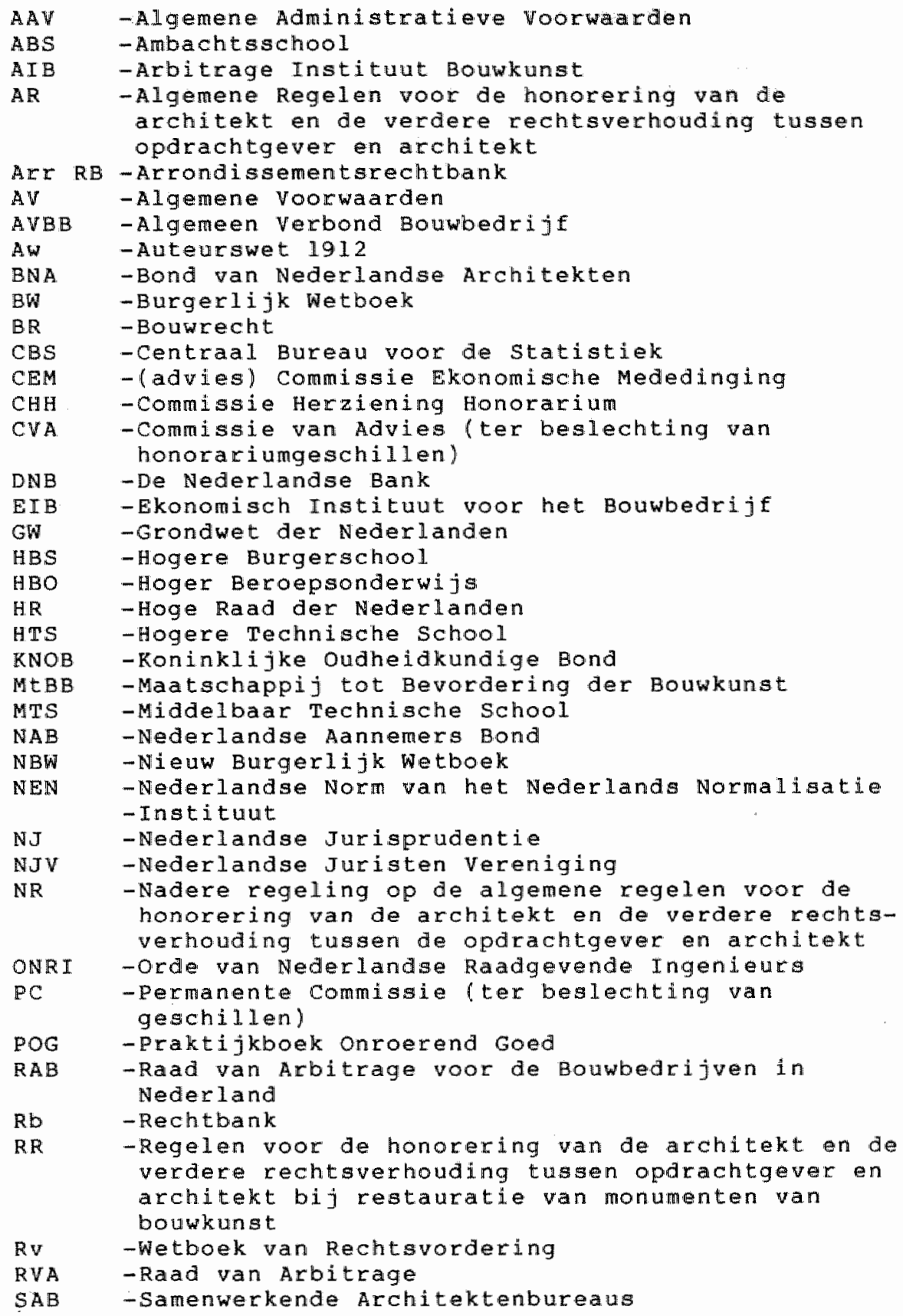


STC -Rapport Schaalvergroting Taakstelling en Concentratie in het onderwijs

SR -Standardregelen Rechtsuerhouding opdrachtgeveratchitekt

TH -Technische Hogeschool.

TU - Technische Universiteit (TUD te Delft, TUE te Eindhoven)

UAR -Uniform Aanbesteding Reglement.

VDI -Vereniging van Delftsche Ingenieurs

WVHR - Weekblad ran het Recht 


\section{INLEIDING}

I. U Uitgangspunten van het onderzoek I.1.1 probleemstelling I.1.2 methoden van onderzoek I.1.3 tijdvak van onderzoek

I.2 Historische ontwikkelingen van de annemer en de architekt tot ca. 1850

I.2.1 het arzelend begin

I.2.2 het ontstaan en de ondergang van de gilden

I.2.3 het verschijnsel aanneming van werk/

I. 2.4 het ontstam van de standaardvoorwarden bij aanneming van bouwwerken

I. 2.5 van bouwmeester tot architekt

I.3 Het rechtskarakter van de overeenkomst tussen de architekt en de opdrachtgever

I.3.1 algemeen

I.3.2 de ontwerp-opdracht an de architekt

I. 4 Samenvatting

I. 5 Notenlijst 


\section{INLEIDING}

T. 1.

Uitgangspunten van het onderzoek

$\mathbb{I}: 1.1$

problemstelling

Geen proces $\mathfrak{i s}$ meer verknocht met matschappelijke ontwikkelingen dan de totstandkoming van het gebouwde. Het laat $z$ ich indenken dat het inrichten van de beschermende omhulling van de eerste primitieve levensvormen, qua organisatie van het wordingsproces, even eenvoudig is als het geboumde zelf.

Met de verfijning van de matschappelijke verhoudingen, en de daarmee gepard gaande kulturele ontwikkeling, wordt niet alleen het gebouwde zelf zeer veel gekompliceerder. mar ook de wijze warop het tot stand komt. Dit stat in rechtstreeks verband met het specifieke aspekt van de gebondenheid van de architektuur als kunstuiting. De architektonische vormopgate wordt immers mede bepald door programmatische, technische en ekonomische faktoren. Daarnast zijn er ook nog de juridische beperkingen van de bouwlokatie.

Vele geschillen kwamen en komen nog voort uit de spanning tussen de architektonische vormtaal, en de andere bepalende komponenten die veelal voor de opdrachtgever gemakkelijker kwantificeerbaar zijn. In het ontwikkelingsproces van het gebouwde doen $z i c h$ verschuivingen voor die parallel. schijnen te lopen aan zich wijzigende maatschappelijke verhoudingen. Een komplicerende faktor is het pluriforme karakter van het begrip "architekt". In de tweede helft van de vorige eeuw was "architekt" vaak synoniem voor de ontwerpend a annemer, terwijl in diezelfde periode vormgevers-in-optima-forma zoals dr. P.J.H. Cuypers hun stompel arukten op stads-en dorpsgezicht.

De matachappelijke positie van de onafhankelijke architekt is, van kort vóór de tweede wereldoorlog tot geruime tijd daarna, vrij stabiel. Hij is de spil in het ontwikkelingsproces van architektonische visie tot gerealiseerd projekt, zij het dat ait in de sfeer van de woningbouw weer iets anders ligt dan in de overige bouwsektoren. De latste twintig jaar is er echter sprake van ingrijpende wijzigingen. Het verwarrende darbij is dat men niet kan stellen dat de architekt thans in beginsel anders funktioneert dan vroeger het geval was. Ook nu komen er "ontwerpende aannemers" voor, evenzeer als architekten die los van de materie ontwerpen en desondanks groot aanzien geniteren. 
ook binnen het bouwproces zelf is de positie van de architekt thans veelvormiger geworden: soms toch weer spil van het bouwproces en soms uitvoerder van delen van opdrachten. Juist daarom is nu een onderzoek nati de ontwikkeling van de rechtspositie van de architekt van belang.

De ingrijpende wijzigingen behelzen vooral de juridische positie van de architekt en de toetsing van zijn prestatie aan de letter van het kontrakt of de opdracht. Dit heeft genoopt tot de herziening van de standaravoorwarden, mede onder druk van een andere houding tot kontraktpartners in het algemeen en de nieuwe Wet Algemene Voorwarden. Vanaf 1921 bepalen de Algemene Regelen van de BNA grotendeels de kontraktuele rechtspositie van de architekt. Een analyse van de belangrijkste aanpassingen makt darom deel uit van deze studie. Sinds $1974 \mathrm{zijn}$ pogingen ondernomen om de Algemene Regelen op een nieuwe leest te schoeien en te vervangen door de standaardvoorwarden Rechtsverhouding Opdrachtgever-Architekt. Vele suggesties en koncepten zijn nadien zonder resultaat de revue gepasseerd. viteindelijk werd in 1987 deze nieuwe regeling vastgesteld en ingevoerd. Deze SR 87 wordt in de analyse betrokken.

In buiten-kontraktuele zin vindt de verandering zijn uiting in de ontwikkeling van het $\mathrm{Nieuw}$ Burgerlijk Wetboek, en de zich wijzigende visie op het fenomeen aansprakelijkheid en de wettelijke bescherming van titel of beroep.

Deze studie dient ertoe om na te gaan hoe de matschappelijke ontwikkeling van de architekt, in de gedaante van de zelfstandige beroepsbeoefenaar, zich heeft voltrokken en hoe dat juridisch is vertald. Derhalve, of de regeling van de rechtspositie van de architekt, in zoverre al aanwezig, gelijke tred heeft gehouden met de ontwikkeling van de matschappelijke aspekten van zijn beroepsuitoefening.

Deze juridische aspekten zijn derhalve tweërlei:

- de kontraktuele relatie met de opdrachtgever en

- de buiten-kontraktuele relatie, zoala de algemene regeling van de rechtspositie, de bescherming van titel en beroep, en de auteursrechtelijke bescherming.

Gezien de bijzondere positie van het Auteurerecht met betrekking tot de bouwkunst is an dit facet een apart hoofdstuk gewijd.

I. 1.2

methoden van onderzoek

Het blijkt dat de matschappelijke positie van de partijen, zowel in hun onderlinge relatie als individueel, in de loop der tijden grote veranderingen hebben ondergaan ten aanzien 
van hun rol in het bouwproces.

De rol van de architekt heeft, in de tijd gezien, andere interpretaties gekregen. De tijdsfaktor is dus bij deze studie van groot belang en fungeert dechalve als parameter.

In dat verband is het volgende citat relevant:

"Tijd is een essentiele parameter van het onderzoek, geschiedenis, een onmisbare component, geschiedenis, die vroeger zo dikwijls is aangevochten als hinderpaal voor architektonische vernieuwing, heeft har entreb gemakt al basisinstrument voor het verwerven van inzicht in de toekonst van het beroep".

(Tzonis/Le Faivre Bouw 1982/23)

Uitgande van het in de probleenstelling verwoorde objekt van onderzoek is begonnen met de bestudering van publikaties in de (bouw)vakliteratuur, speciaal ten anzien van de juridighe kwesties. Daarna is onderzocht in hoeverre de gesignaleerde matschappelijke verschijnselen worden gevolgd door de jurisprudentie of regelgeving.

Het eerste deel van dit onderzoek behelst derhalve een literatuurstudie met betrekking tot de matschappelijke verhoudingen.

De matschappelijke analyse beslati $0 . a .:$

- "De Opmerker", de jaargangen 1883 - 1918

Dit blad verscheen onder auspiciên van het genootschap

Architectura et Amicitia.

- "Het Bouwkundig Weekblad" van 1854 - 1940 en 1945 - 1978 orgaan van de Matschappij tot Bevordering der Bouwkunst BNA.

- "Bouw" van 1945 - 1984

Uitgave van het Bouwcentrum te Rotterdam.

Aan deze basis zijn vele andere, in de tekst aangehaalde, publikaties ad hoc, alsmede standaardwerken toegevoegd.

Het tweede deel van het onderzoek wordt gevormd door een onderzoek naar de juridische ontwikkelingen en jurisprudentie door middel van literaturatudie.

De juridische analyse beslate:

- Het Weekblad van het Recht $(1852-1938)$ op de onderwerpen: a anbesteding

a anneming

a)

ansprakelijkheid

architekt

a teursecht

b)

bouwmeester

huur/verhuur van diensten

lastgeving

machtiging 
- De Nederlandse Jurisprudentie op de onderwerpen: aanneming anbesteding architekt auteurstecht b) auteurswet

b)

a) Hieronder valt ook lange tijd de rechtsverhouding architekt/opdrachtgever, zeker tot 1930, howel de algemene juridische kwalifikatie voor deze overeenkomst op dat moment reeds als huur van diensten werd gezien.

b) In relatie met hoofastuk 6 .

- Publikaties van de Commissie van Geschillen BNA C.q. het Arbitrage Instituut voor de Bouwkunst 1946 - 1984 Publikaties van de Rad van Arbitrage voor de Bouwedrijuen in Nederland.

"Bouwrecht" voorzover het relevante publikaties. betreft, vanaf 1963

Bouwrecht verschijnt onder auspicien van het Instituut voor Bouwrecht

Aanvankelijk wordt bij geschillen tussen architekt en opdrachtgever hoofdzakelijk door de rechter beslist. Eerst na het ontstaan van standaardwoorwarden in de twintiger jaren gaan arbitrale vonnissen de overhand krijgen.

I. 1.3

tijdvak van onderzoek

De tweede helft van de $19 e$ eeuw is gekozen als eerste te onderzoeken periode. Na afscheffing van het gildesysteem voor de burgerbouw tijdens de Bataafse Republiek in 1798 , ontstond in de wereld van de burger-bouw een nieuwe figuur: de aannemer, als zelfstandig ondernemer voor gehele, stedelijke bouwwerken. Vobr die tijd kwam de aanneming van gehele werken slechts sporadisch voor. Uit deze aannemer heeft $z i c h$ na 1850 mettertijd een tweede figuur ontwikkeld. de zelfstandige architekt. Bruynzeel (*1) meent dat de term "architekt" vór het midden van de 19 e euw slechts eenmal in publikaties voorkomt. Pas na het ont gtaan van deze zelfstandige architekt is een onderzoek naar de rechtspositionele aspekten van de afzonderlijke bij het bouwproces betrokkenen zinvol.

Het is voor een goed begrip van de situatie na 1850 noodzakelijk om ook de gang van zaken van vóbr die tijd in het onderzoek te betrekken. In een tot deze inleiding behorende paragraaf (I.Z) is daarom enige andacht besteed aan de ontwikkelingen vanaf het jaar 1000 tot 1850 .

Het verdere onderzoek 1 s opgesplitst in twee perioden: van 1850 tot 1940 en wan 1946 tot 1986 . 
Immers, de matachappelijke positie van de architekt is, tot 1940 terk in ontwlkkeling in positieve zin, terwijl na 1946 het ongekeerde het geval is. Daarbij kan vooral in het eerste tij javak niet voorbijgegaan worden aan de matschappelijke en rechtspositie van de aannemer. De matschappeijjke wardering of het vooroordeel treft vak hen beide in gelijke mate, terwijl er tevens van wederzijase beinvioeding sprake is.

1.2

Historische ontwikkelingen van de aannemer en de architekt tot ca. 1850

I. 2.1

het arzelend begin

De eerste architektonische ontwikkeling in ons land schijnt te hebben plaatsgevonden in de $7 \mathrm{e}$ eeuw toen engelse geestelijken zich met onze kerkbouw hebben ingelaten. Wat aan architektonische prestaties werd verricht was tot aan de lie eeuw dan ook voornamelijk het werk van monniken. De wereldse meester-metselaar doet eerst $z$ ijn intrede rond 1300 .

In Duitsland ontwikkelen zich al snel broederschappen, warbij die van de "steinmetzen" ook in juridisch opzicht van groot belang zijn geweest (*2). Reeds in 1400 werden de regels welke het ambacht bepalden, op schrift gesteld. voor het Duitse gebied was zelfs een beroepsinstantie ingesteld in Regensburg.

Heideloff (* 3) stelt dat de "bouwhut" een instelling is dite reeds van v6or het begin van de jaartelling dagtekent. Waarschijnlijk is daarmee echter bedoeld een bouwcorporatie zoals ook de Grieken en vooral de Romeinen (collegium fabrorum) die kenden. Deze Romeinse corporaties bleven bestaan tot de 5 e eeuw onder Honorius, daarna deden de oorlogen ook hier hun ontwrichtend werk. Deze wereldse bouwcorporaties hadden eventueel qua organisatie niets gemeen met de uit de geestelijkheid voortgekomen "Bauhtote".

De "Bauhuttei" heeft vanaf de $9 e$ eeuw tot de 18 e eeuw (in Duitsland) grote betekenis gehad voor de sakrale bouwkunst. Deze bouwgemeenschappen waren gebaseerd op een zeer strakke hiécarchische opbouw waarbij de Meester het ontwerp makte en toezag op het funktioneren van de organisatie en het resultaat van het werk. De "Bauhtte"- organisatie kende ook een eigen rechtssysteem, na 1459 zelfs in drie lagen. Het is niet duidelijk of, en in hoeverre, er verbanden bestaan tussen de geestelijke Bauhtate en de wereldijike bouwbroederschappen en hun ontwikkeling. 
I. 2.2

het ontstaan en de ondergang van de gilden

De feitelijke ontstaansgrond van de gilden was de drang naar een kwaliteitsgarantie van het ambacht voor de opdrachtgever, hetgeen zeker succesvol is gebleken. Het gevaar echter dat alle vormen wan beroepsbescherming bedreigt, is, dat ze an zichzelf te gronde gaan. Daarvoor zijn verschillende oorzaken aan te wijzen.

Zo is daar de kartelvorming en het daarmee verbonden, matschappelijk isolement. Wanneer er, door het ontbreken van konkurrentie duidelijke kenmerken van machtsmisbruik aan de dag treden, worden er tegenkrachten opgeroepen. Voorts wordt de interne konkurrentie-positie beperkt door middel van zware toelatingseisen en er kunnen konflikten ontstaan met aanpalende beroepsgroepen.

Bij het gildesysteem bleek op den dur een gezonde ontwikkeling onmogelijk te worden vanwege de rem op de verbetering en rationalisering van de produktietechnieken. Dat hield immers een bedreiging in voor de positie van de gildemeesters. Deze behoudendheid heeft een forse bijdrage geleverd aan de impopulariteit van het systeem.

Ter illustratie van eerder genoemde konflikten met verwante beroepsvelden diene de zesendertig jaar aurende ruzie aan het eind van de $18 \mathrm{e}$ eeuw, tussen schrijnwerkers en timmerlieden in Brugge over de vraag, aan wie het gebruik van de lijmpot was voorbehouden. Bij het concordaat van 1455 was dit voorrecht namelijk toegekend aan de schrijnwerkers en de eindeloze ruzie heeft daaraan niets kunnen veranderen. Het ging hiler pur om de commercie: zonder lijm was men aangewezen op ambachtelijke verbindingen en dat beperkte de "markt" aanzienlijk. De schrijnwerkers waren namelijk makers van doodkisten en die werden verlijmd. De 1 ijmpotkwestie was dus een poging van de timmerlieden om $z i c h$ een konsistent marktaandeel toe te eigenen. In Frankrijk werden in de 18 eeuw jaarlifks door de gilden een miljoen livres uitgegeven aan proceskosten (* 4). In oostenrijk hield het systeem het 't langste uit: tot vér in de 19 e eeuw kende men daar nog vormen van ambachtelijke beroepsbescherming.

De machtspositie van de Meester binnen het gilde had ook een sociaal gevolg: de scheiding tussen kapitaal en arbeid - het standsverschil - ontstond. Alg reaktie daarop sloten de gezellen zich aaneen in "knechtgilden" die soms winkels (werkplaatsen) "vuyl" verklaarden vanwege de onacceptabele omstandigheden waronder daar moest worden gewerkt. De uitholling van binnenuit van het systeem ging darmee voort, het ontbreken van konkurrentie en de daaraan verbonden prijsopdrijuing deed de rest. zo verwerd het commercieel alleenrecht tot matschappelijk isolement. 
Wa de instelling van de Bataafse Republiek werd, zoals ook in Frankrijk, in 1798 het gildesysteen afgeschaft.

Toch heeft dit abrupte einde van een zichzelf overleefd hebbend, maar op het moment van afschaffing reeds honderden jaren bestaand stelsel, een geweldig schokeffekt gehad op het bouwvak. Niet alleen in matschappelijke $z$ in, maar ook ambachtelijk. Het heeft zeker honderd jaar geduurd voor er weer van een redelijk evenwicht kon worden gesproken. Architekt Weismann klaggde in 1909 (*5) nog over het kwalitatieve verval van het ambacht en blikte verlangend terug naar het gilde als opleidingsinstitut. Vooral de aannemerij moest het ontgelden: "wij weten dat deze instelling nog geen eeuw oud is: toch heeft zij zulke wortels gemakt, dat het heel wat moeite zal kosten dit onkruid ult te roeien". Zijn pleidooi voor ambachtsscholen vond echter gehoor en de ambachtelijke beroepsopleiding voor het bouwvak kwam in de daarop volgende jaren op gang.

I. 2.3

het verschijnsel aanneming van werk/aannemer

Wellswar deed de afschaffing van de gilden "de aannemer" als zelfstandige ondernemer als "burger-bouwer" ontstaan. maar aanneming van werk als kontraktvorm ontstond reeds veel eerder $(* 6)$. Een bekend geval 1 s de a anbesteding in 1601 van de sluis aan de St. Anthoniesdijk te Amsterdam. Enige tija daarvoor was de aanbesteding van een aantal schepen voor de Voc gestrand op het protest van de Amsterdamse scheepstimmerlui, omdat hún "vaste" lasten hoger waren dan in de andere steden en er daarom geen sprake kon zifn van eerlijke konkurrentie. zij kregen het werk uiteindelijk voor de door hen bedongen prijs. Reeds in 1565 werd te Amsterdam bij de keur op het timmeren en rooien (het vaststellen van de rooilijnen en daarmee een vroege voorloper van de bouwverordening) voorgeschreven dat Bestek en Voorwarden van alle aangenomen werken schriftelijk dienden te worden opgesteld en tevens als grondalag zouden dienen voor de beslechting van geschillen ( 7). De a anneming van werk geschiedde tot de opheffing van de gilden (bif de statsregeling 1798 art. 53). doorgans ambachtsgewijs, althans bij kleinere werken warbij de koördinatie in handen was van één dezer mbachten, dus steenhouwer, timerman of metselaar. De gilden waren stadgewijs georganiseerd hetgeen $0 . a$. te maken had met het heffen van invoerrechten. Ook de bouwplannen werden valk gemalkt door de steenhouwer (beldsnijder) of (stads)timmerman. Ook witzonderingen darop kwan echter, zoals de kunstschilder en Utrechtse stadsbesturder Moreelse, die verschillende gebouwen in zijn stad ontwierp, terwijl een bouwmester als Jacob van Campen evenmin uit het ambacht voortkwam. 
Dit soort bouwplannen was doorgaans grootschaliger van aard en werden geraakt in opdracht van stadsbesturen (* 8 ). In de militaire sektor werden plannen gemakt door genieofficieren die onder de staten-Generaal ressorteerden. Grootschaliger projekten manifesteerden $z i c h$ vooral tegen het eind van de 18 e eeuw, niet alleen in de bouw maar ook in de industrie. zo ontstonden er vooral in de zilverfabrikage vrij grote produktiesystemen.

Met de aftakeling van de gilden kwam ook de vakopleiding in gevaar, immers, er ontbrak een alternatief voor de meestersopleiding. De gevolgen daarvan deden zich al snel voelen. De zich manifesterende behoefte an schciftelijke grondslagen voor de kontrakten doet vermoeden, dat er een toenemende noodzaak bestond tot toetsing van de kwaliteit van de geleverde prestatie in juridische zin. Het

kwaliteitsverval blijkt evenzeer uit de ontboezeming van een meester-metselaar uit 1775 (* 9)

"... Mar laat ik voortgaan en een onbeschroomd opleggen de Reden van war somige onzer zware Muuren in zulk een beschreijenswaardige stat z⿺jn. Omdat de goede trouw, de eerlijkheid, als verbannen is geworden onder de Arbeiders en Meesters en de Rekeningen daar door zeer hoog gemaakt wordende, heeft men begonnen de Metzelwerken Aantebesteeden, in eene Massa: jeder heeft, or het Werk te hebben, de Prijs daarvoor zoo laag gesteld, dat $z i j$ er niet mede konden uitkomen: tegen Schaaden konden zij niet; wat dan gedaan?

Slegte en mindere zoort van $\mathrm{Kalk}$ en van steen gelevert; allerlei Bedriegeryen te werk gestelt, als te veel Zand in de Kalk gedaan; de Kalk niet wel. bebouwt; de Tras in dezellve benodigd moedwillig verzuimt; de goede principes van het Metzelen verwarloost; en om minder Dagloon te betalen, onkundig, onbekwame Knegts en Jongens gebruikt; oude kalk-tobbens en kruiwagens in de Muuren gemetzelt, in

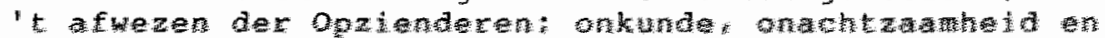

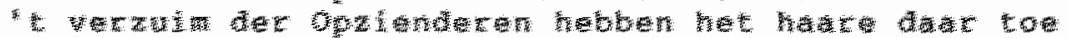

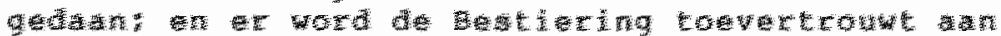

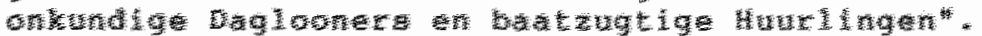

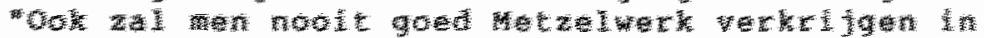

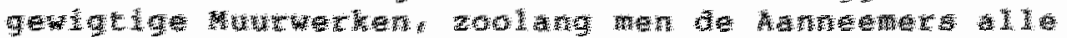

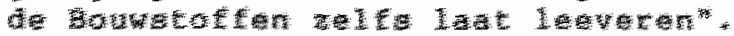

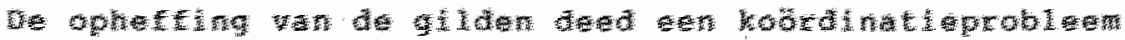

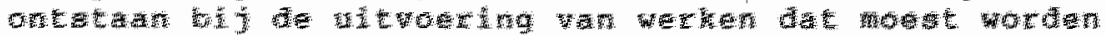

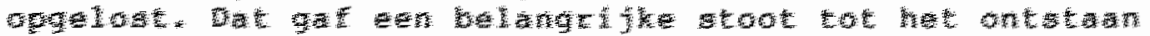
和需

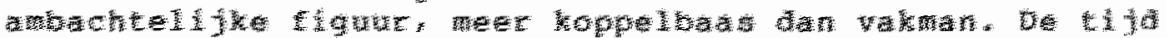

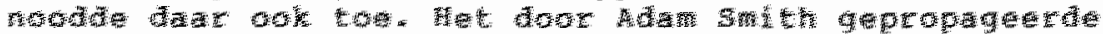

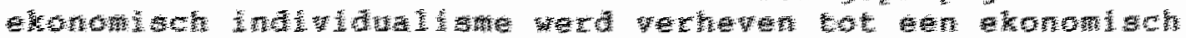
en pon

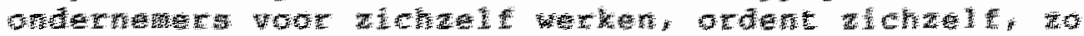

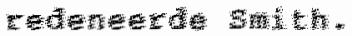


Wen total verschil met het daaran voorafgaande mercantilisme, warbij leiding en ordening van bovenaf het uitgangepunt vornde. Zelfordening van de matschappij komt wort uit konkurrentie, hetgeen voor het bouwbedrijt de openbare besteding tot gevolg heeft gehad. Deze openbare begtedingen veranderden de gildemeester van weleer in een a anemer-nieuwe stijl, zij het vila een langdurig proces.

I. 2.4

het ontstaan van de standaardvoorwaarden bij anneming van bouwerken

Zoals reeds opgemerkt gaf de politiek-ekonomische situatie aanleiding tot het verschijnsel aannemer als kontraktpartner-voor-gehele-werken, warbij de ambachtelijke vakkennis van deze figuur op de tweede plaats kwam. Het zakelijke karakter van de aannemingsovereenkomst prevaleerde en makte toetsing van bindende aanbiedingen steeds meer noodzakelijk.

Een felle konkurcentiestrijd in de ekonomisch slechte omstandigheden na 1800 werkte in dat opzicht katalyserend. De stap naar standaardvoorwarden was daarom toen nog mar een kleine. De eerste officiele Algemene voorwarden verschenen dan ook al in 1815 en werden vastgesteld bij Koninklijk Besluit vanwege het "Corps Ingenieurs der Genie". In 1839 volgen de eerste Algemene Voorwarden van "Waterstat" met de herzieningen in $1860,1866,1876,1882$, $1892,1901,1915,1919$ en 1930 (*10).

Het ligt zeer voor de hand om an te nemen dat de behoefte aan toetsing niet alleen bij "Waterstat" ontstond, maar tevens bij de partikuliere opdrachtgever. Dit heeft in feite de stoot gegeven tot de verdere ontwikkeling van het verschijnsel van de onafhankelijk architekt nást de annemer. De meeste partikuliere opdrachtgevers waren Immers leek op bouwkundig gebied wardoor de behoefte aan een formulering en beoordeling van de aannemersprestatie door een deskundige niet kon worden ontbeerd. (zie ook hoofduk I. 2.5.$)$

De voorwarden waren zozeer toegesneden op het voorkomen van chicanes van aannemerszijde, dat de weegschal van vrouwe Justitia op een has on woorstelbare manier doorsloeg in het voordeel van de a anbesteder. Deze bestond alras niet alleen uit "Waterstan" maar ook uit menig partikulier, die mar al te zeer geneigd was het voordelige alktat te volgen.

Het verzet wan de a annemers bleef lang uit, mede vanwege de krapte op de bouwmarkt. De aannemers in het begin van de 19 e euw waren voornamelijk aannemers van grond- en waterbouwkundige werken. In de burgerbouw werd nog hoofdzakelijk gewerkt vanuit én van de ambachten, metselaars of timmerlieden, warbij de koordinatie van de overige betrokkenen bij de eerste of de tweede lag. 
Het werk was in hoofdzadk onderhouds- en reparatiewerk, er kwamen weinig burgerlijke bouwwerken tot stand.

De rechtsongelijkheid van partijen kwam a anvankelijk mede voort uit, hoe vreemd het ook klinkt, de eenvoud van het werk toendertijd. Er waren nśch veel ingenieurs, noch veel aannemers; men kende elkar en elkaars opvattingen alsmede de ard van het werk, voornamelijk bestaande uit sluizen, duikers en bruggen nar overbekend koncept. "Ten genoege van de Direktie was derhalve een afdoende kwaliteitsomschrijving. Handhaving echter van deze begrippen bij een grote diversifikatie van het werk, en vooral komplicering, moést op den duur tot ernstige konflikten leiden, vooral naarmate de partikuliere bouw qua omvang belangrijker werd dan het waterstaatswerk. Talloze paragrafen $(442 \mathrm{t} / \mathrm{m} 447$, $451.453)$ van de toenmalige AV 1882 maakten "de partikuliere werkgever (lees: ambesteder) niet alleen partij, mar ook rechter, opperrechter en zelfg tot beul" (* 11$)$.

Zoals hierna in hoofdstuk III.5.2 nog zal blijken is het de grote verdienste geweest van de utrechtse architekt F.J. Nieuwenhuizen dat hij in zijn "Beschouwingen omtrent het Aanbesteden van Werken" (1885) opkwam tegen het schrijnend onrecht bij het bouwen in die dagen. In een zestal stellingen gaf hij de voornamste grieven weer (* 12 ).

Zoals gebruikelijk leidde ook hier de matschappelijke druk tot een bundeling van belangen. In 1895 werd de Nederlandsche Aannemersbond opgericht die zich zeer beijverde voor wijziging van de artikelen $1640-1653 \mathrm{BW}$. De Bond was daarin niet zeer succesvol. De acties die herziening van de Algemene Voorschriften beoogden hadden meer succes en leidden, zij het schoorvoetend, tot een verbeterde rechtspositie van de aannemer.

I. 2.5

van bouwmeester tot architekt

De tientallen jaren durende diskussie cond art. 1645 BW vond zijn oorsprong in het feit, dat bij de formulering van het desbetreffende wetsartikel vanuit de code civil, de zelfstandige architekt onbekend was. Ontwerper en uitvoerend ambachtsman traden dus op als personele unie. Weliswar ontstond in ons land in de tweede helft van de 19e eeuw de figuur van de zelfstandige architekt, mar het bleef én vorm naast de besta ande, díe een vermenging inhielden met allerlei aanverwante beroepen.

Het is warschijnlijk, zoals ook in hoofdstuk I.2.4 al is opgemerkt, dat de afschaffing van de gilden, het optredende verval van kwaliteit in het bouwvak, en de ontwikkeling in de annemerij, de behoefte deed ontstan aan een onpartijdige figuur. Deze kon de zakelijke belangen van de 
opdrachtgewer behartigen en dan teveng nog de planontwikeling ter hand nemen. Zoals ook thans nog het geval is, bestonden er talrijke verschillen in status en beroepsultoefening van de architekt: van ontwerpendaannemer tot youmvirtuoos. Er was geen spake van een plotselinge overgang, het was meer zo dat de architekt als zelfstandig beroepsbeofenar nast de bestaande vormen zijin intrede deed en gaandeweg an betekenis won.

Een pril begin van sociale ordening tekent zich af met de oprichting van "De Matschappij tot Aanmoediging der Bouwkunde in 1819. In 1830 is zij echter van het toneel verdwenen, on onbekende redenen. Van deze Matschappij waren overigens geen "architekten" lid, dat fenomeen bestond toen nog niet. Twaalf jaar later, op 12 januari 1842, wordt een nieuwe vereniging opgericht: de Matschappij tot Bevordering der Bouwkunst. Haar lotgevallen worden beschreven in hoofdstuk II.1.3.

Het ontstaan van de zelfstandig ontwerper betekende een breuk tussen kunst en ambacht. Deze scheiding verdiepte zich snel, zobeer zelfs dat de uitvoerende kant geheel een aannemerszak werd. De thans noodzakelijke sloop van vele representatieve bouwwerken uit het latst van de 19 e euw vindt zijn oorzaak in solitaire artistieke opvattingen van de ontwerpers van die dagen, en de onervarenheid van de aannemerij met de konstruktieve problemen die dat met $z i c h$ mee bracht. Soms ontstond er een verschil in ontwerpend architekt en direktievoerend architekt. Zo schijnt de rol van de $19 e$ eeuwse Amsterdamse stadsarchitekt Zocher jr. bij de totstandkoming van zijn Beurs, beperkt te zijn geweest tot het ontwerp, een andere kollega was belast met de uitvoering. Hoezeer de ontwerpend-architekt vervreemdde van de gebondenheid aan de materie zal nog blijken uit de geschiedenis van de beroepsopleiding.

Met de opkomst van de architekt als vrije beroepsbeoefenaar kwamen er ook voor de bepaling van zijn kontraktuele rechtspositie regelen in $z$ wang. De eerste franse honocariumregeling zag in het parijoe decreet van "12 pluviose an VII", (I februari 1812) het licht.

De buiten-kontraktuele situatie van de onafhankelijke architekt is tot $1850 \mathrm{nog}$ uiterst pover. Van een beroepsof titelbescherming is nog geen sprake. Van auteursrechtelijke bescherming van zijn werk zal eerst in de dertiger jaren van de volgende eeuw sprake zijn. 
I. 3

Het rechtskarakter van de overeenkomst tussen de architekt en de opdrachtgever

I. 3.1

algemeen

Een onderzoek naar de rechtspositie van de architekt is niet zinvol zonder definitie van het rechtokarakter van het architektenkontrakt. Aangezien de diskussie hierover zich voornamelijk voltrak tussen 1850 en 1940 is bij deze paragraaf afgeweken van het beginsel dat dit inlelidend hoofdstuk een ontwikkeling schetst vóor 1850 .

Kenmerkend voor de a anvankelijk onduidelijke positie van de zelfstandig architekt is het feit dat er in juridische $z i n$ heel lange tijd meningsverschillen bestonden omtrent de kwalifikatie van de bovenvermelde overeenkomst. In principe staan daarwoor, afgeleid uit het Burgerlijk wetboek (* 13$)$, arie typen overeenkomsten ter beschlkking, te weten:

- het verrichten van enkele diensten $1637 \mathrm{BW}$

- arbeidsovereenkomst

- aanneming van werk

$1637 \mathrm{a}, 1637 \mathrm{~d}$ BW e.v. $1637 \mathrm{~b}, 1640$ BW e.v.

Elk van deze drie overeenkomsten kent har elgen regels. Het minst omvangrijk en dwingend zijn die regels bij de "enkele diensten": zij wordt beheerst door "dezelve eigene bepalingen en bedongene voorwarden, en bij gebreke van deze door het gebruik" (1637 BW). De "aanneming van werk" (1640 BW e.v.) kent enig regelend-recht ten anzien van de risikoverdeling, aansprakelijkheid, meerwerk en de beẻindiging. Het meest dwingend geregeld in vijuwel alle aspekten is de arbeidsovereenkomst (1637d BW-1639dd BW). Voor alle typen overeenkomsten gelden nast de specifieke, uiteraard ook de algemene regels van het kontraktenrecht (1356 BW e.v.). Voor de rechtsverhouding van architekt tot opdrachtgever is het derhalve van groot belang hoe de overeenkomst gekwalificeerd moet worden.

Een komplicerende faktor is dat het handelen van de architekt niet beperkt blifft tot feitelijk handelen, mar dat uit de overeenkomst ook de bewoegaheid voortvioeit om de opdrachtgever te vertegenwoordigen.

I. 3.2

de ontwerp-opdracht an de architekt

Kon een ontwerp-opdracht worden gezien als aanneming van werk? Dat van de architekt ook in zijn ontwerpopdracht een arbeidsprestatie werd verlangd stond buiten diskussie. Echter niet, of deze als aanneming van werk of anderszins moest worden aangemerkt. Zonder enige twijfel heeft de reeds gesignaleerde vermenging van het aannemers-en architektenberoep aan deze onzekere toestand ten grondslag gelegen. 
central stond de vraag of de prestatie in materiéle of ideële zin moest worden geinterpreteerd, derhalve, of ook een geestelijk produkt het voorwerp kon zijn wan een resultaatsverbintenis (* 14$)$, van anneming van werk.

De kwalifikatie van de overeenkomst zal zeker zijn beïnvlaed door de pluriformiteit in de beroepsuitoefening door de architekt. Hoe "materieler", hoe meer men zou nelgen naar "aanneming van werk", hoe ideèler, hoe meer naar "huur van diensten". Zelfs in 1937 nog werd over de "huur van diensten" en "aanneming van werk" gediskusisieerd. Het Amsterdamse Hof besliste toen ten gunste van "huur van diensten" ondat het hier uitsluitend een ontwerpopdracht aan de architekt betrof (* 15). Hendrix (*16) gaat op de situatie rond 1927 uitvoerig in. Hij konkludeert dat de wet zich niet tegen de kwalifikatie "aanneming" voor de ontwerp-opdracht verzet. Hij baseert zich daarbij op het reeds aangehalde vonnis van de Rechtbank te Den Bosch en de toenmalige franse rechtspraak zoals gereleveerd door mr. Van creveld (*17).

Men dient zich te realiseren dat an de juridische kwalifikatid ook matschappelijke kanten waren te onderkennen. Verrichten van diensten kwam voor bij doktoren en advokaten, aanneming was ambachtelijk werk en werd derhalve lager gewaraeerd. Van deze strijd tussen ideëel en materieel zijn vele voorbeelden voorhanden. Eén ervan treft men aan in het "Weekblad Nederlandsche stoompost" (* 18) warin men zich afvraggt, "wat is een architekt" : "rij is geen koopman, geen industrieel, maar een artiest: hij belast de aannemer met de stoffelijke uitvoering van zijn geestelijke arbeid".

Men zag de oneigenlijke vermenging van architekt en aannemer zelfs als een achteruitzetting van de bouwkunst. zo werden architekten als ondernemers verplicht zich van een "patent" te voorzien, zulks mede als gevolg van de belastingwetgeving in die dagen (zie blz.27).

Toch zag mr. J. Limburg (* 19) de ontwerp-opdracht primair als resultatsverbintenis, en dus als aanneming van werk, al betreft het een geestelijk produkt. Hij achtte een koppeling aan een matschappelijke status voor de juridische kwalifikatie van de overeenkomst zelfs ongrondwettelijk. Een dergelijke koppeling was indertijd zeker anwezig: de dokter werd gezien als lasthebber, doch de baker verhuurde zich, aldus Limburg.

Dr. W.A.M. Cremers (* 20) prefereerde voor de ontwerpfase de "enkele diensten", echter soms "aanneming van werk". Dat latste was zijns inziens het geval wanneer onafhankelijk van de omvang van het werk een vaste prijs wordt overeengekomen voor het ontwerpwerk. Anders was het "enkele diensten" onder de werking van $1637 \mathrm{BW}$. 


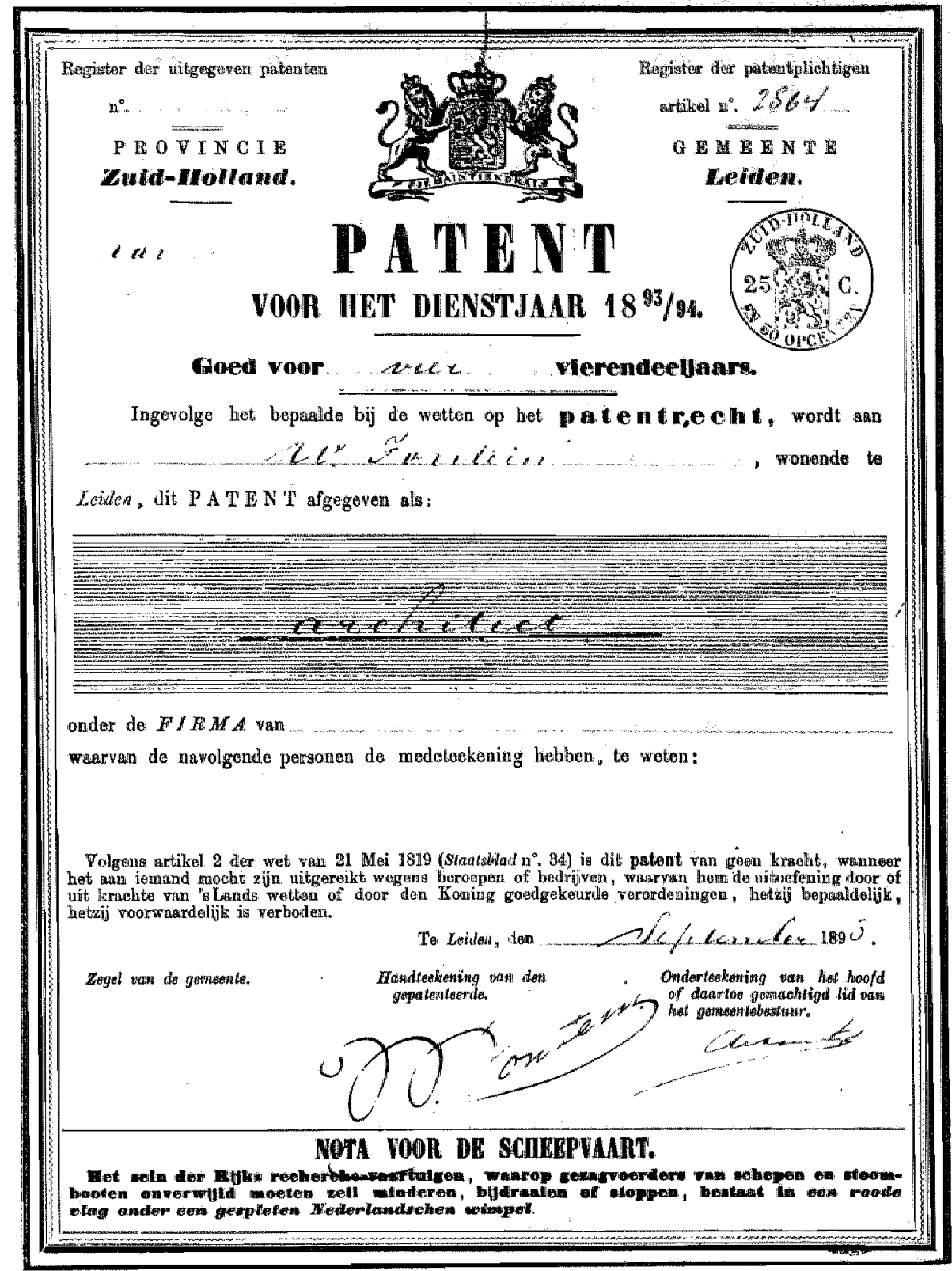


Sporadich komt men de waag tegen of de architekt-indinstwerband ad hoc werkaam is in de zin van $1637 \mathrm{BW}$ (arbeidsovereenkomst). Deze kwestie speelde bij een langdurig proces voor de Rechtbank te Zierikzee in 1879 die uiteindelijk tot huur wan diensten konkludeerde (*21).

Het blijft chter merkwardig dat in het rapport "straf-en Civielrechtelijke verantwoordelijkheid van technici bij de ultvoering van werken" vitgebracht in 1887 aan het Bestuur wan de Vereniging van Burgerlijke Ingenieurs, werd gesproken over de principaal als "werkgever". Dit zou erop kunnen wijzen dat toendertijd de rechtsverhouding architekt/principal als arbeidsovereenkomst werd gezien. Tegen deze opvating is veelvuldig aangevoerd dat er geen sprake is van een duurverbintenis, hetgeen voor de arbeidsovereenkomst essentieel werd geacht.

Aangeduid is hoe moeilijk de scheiding bepaald kon worden tussen de begrippen "aanmeming van werk" en "enkele diensten" bij de aanvaarding door de architekt van opdrachten voor ontwerpen. Tegen 1940 was "enkele diensten" algemeen aanvard ondat het "annemersimago" van de architekt dan definitief tot het verleden behoort. Het vrije beroep van architekt is dan algemeen erkend. In hoofdatuk $V$ zal duidelijk worden, dat de vragen rond de kwalifikatie van de architektenovereenkomst rond 1980 opnieuw rijzen. De diskussie spitst zich dan toe op de kwestie of er sprake is van inspannings- of resultataverbintenissen, als gevolg van de zich wijzlgende rol van de architekt in het matschappelijk gebeuren.

Voor het rechtskarakter van de opdracht tot direktievoering in samenhang met de vertegenwoordigingsbevoegdheid zij verwezen naar hoofdstuk III.2.1.1 en III.2.1.2. 
Nast de probleemstelling en nadere uitleg omtrent de wijze warop het onderzoek heeft platsgevonden, bevat dit eerste hoofdstuk een aantal toelichtingen op situaties die voor een goed inzicht in en begrip voor de gebeurtenissen rond het fenomeen "architekt" na ca. 1850 noodzakelijk zijn.

Zo is daar de ontwikkeling van de gilden en na opheffing darvan, het ontstaan van de "hoofd"-aannemer voor projekten van de burgerbouw.

Aarzelend komt in deze periode voorts een organisatievorm tot stand, warin naast een veelheid van leken slechts een klein aantal architekten participeren. Toch is dit de voorloper van wat later, in de jaren dertig, zal uitgroeien tot een beroeps-organisatie van architekten.

De matschappelijke behoefte aan onafhankelijke architekten werd sterk gestimuleerd door het verval in ambachtelijke bekwamheid van de uitvoerenden en het ontstaan van toetsingsnormen in de vorm van standaardvoorwaarden voor de uitvoering van werken. Deze voorwarden waren zozeer gericht op het voordeel van de opdrachtgever dat hiertegen sterk maatschappelijk protest ontstond. Daarin kwam eerst verandering na een door architekten begonnen diskussie, die daarmee eerst recht blijk gaven van een onafhankelijke positie.

Tenslotte kwam met de opkomst van de zelfstandige architekt ook diens vakbekwamheid aan de orde, met daaraan gekoppeld de vraag wie er aansprakelijk was bij feilen in het gebouwde: de annemer/bouwmeester of de bouwmeester/ architekt. Het in hoofdstuk I.2.5 gereleveerde geleidelijk ontstaan van de onafhankelijk architekt naas de ontwerpend-aannemer, deed een zich lang voortalepende diskussie ontstaan omtrent de interpretatie van art.1645 BW.

Hoewel de architekt als vrijberoepsbeoefenar voor het overgrate deel voortkomt uit de annemerij, bestonden er reeds veel eerder ontwerpers van (veelal grote) projekten, die met de aannemerij niets van doen hadden: militaire bouwwerken ontsproten aan het brein van de Genie. representatieve stedelijke objekten soms aan het brein van kunstgevoelige 1 ieden die het stadsbestuur dartoe kapabel achtte. De architekt als ontwerper én onafhankelijk verantwoordelijke voor de kwaliteit van het gebouwde was echter een novum. 
I. .5

MOTENLIJST

1 J.P. Bruynzee $\mathbb{1}$

- De rechtspositie van de architekt, diss. Leiden 1900

2 J. Winzer

3 Heidelof

4 H. Sieveking

- Die Deutsche Bruderschaften des Mittelalters Gieszen 1859

- Die Bauhbtte des Mittelalters in Deutschland Nurnberg 1844

- Geschichten der Gewerblichen Betriebsformen, Grundriss der Sozial Ekonomik VI abt

5 Bouwkundig weekblad

- 1909 blz. 397

6 mej. M. van viliet

- Het Hoogheemraadschap van de Lekdijk-boven-dams, diss Utrecht $1961 \mathrm{blz}$.

7 prof. Chr. K. Visser c.1.- Inaugurele rede, Delft, 08-10-1915

8 G. Van Reyn

- Geschiedkundige Beschrijvinge der Stad Rotterdam, Uitgeverij Bolle Rotterdam, bliz. 172

9 C. Redelijkheid

- De aloude metzelwerken vergeleken tegen de hedendaagsche, door C.J. Krayenhof beoordeeld en wederlegd, Amsterdam 1775

10 ir.J.J. van der Wal

- De ekonomische ontwikkelingen in het Bouwbedrijf in Nederland, Waltman, Delft 1940, blz. 33

11 R.J.P. Tutein Nolthenius - De Aanbesteding van Rijkswerken, De Ekonomist 1887

12 ir. J.J. van der Wal

- De Ekonomische ontwikkeling van het Bouwbedrijt in Nederland,

13 Burgerlijk wetboek Vierde Boek

$14 \mathrm{Rb}$ Almelo

15. Hof Amsterdam

16 mr. A.J.M. Hendrix

$17 \mathrm{mr}$. I. Van Creveld

$18 \mathrm{WVHR}$

19 mr. J. Limburg

$20 \mathrm{dr}$. W.A.M. Cremers

21 Arr. Rb Zierikzee

$22 \mathrm{mr}$. J. Limburg Waltman, Delft 1940 , blz. $39 / 40$

- titel $7 a-1 e$ afdeling

- 08-01-1908 พ9124-2

- 17-03-1937 NJ 1123

- Het Recht en de Architekt, Tjeenk willink 1927

- Bouwheer en Architekt

- 1860 - nr. 2141/4

- "De Architekt en de Met". BW 06-02-1897 no. 6

- "Architekten en Aannemersrecht", v. Mantgem en de Does, Amsterdam 1926, b1z. 13

- 02-12-1879/4504/2

- "De Architekt en de Wet". BW $06-02-1897$ no. 6 
H O O

DE ONTWIKKELIMG VAN DE MAATSCHAPPELIJKE POSITIE VAN ARCHITEKT EN AANNEMER TUSSEN 1850 EN 1940

II. 1 De architekt

II.1.1 de architekt en de bescherming van zijn titel en beroep

II.1.2 de opleiding voor het architektenberoep

II.1.3 de architekt in organisatorisch verband

II.2 De a annemer

I. 2.1 de aannemersstand

II.2.2 eigenbouw en revolutiebouw

II.2.3 de ontwikkeling van het bouwbedrijf rond 1930

II.3 De opdrachtgever

II. 4 Samenvatting

II.5 Notenlijst 
DE ONTWIKEELIHG VAN DE MAATSCHAPPELIJKE POSITIE VAN ARCHITEKT EN AANNEMER TUSSEN 1850 EN 1940

II. 1

De architekt

II. 1.1

de architekt en de bescherming van zijn titel en beroep

De toename van de bouwaktiviteiten rond 1850 als gevolg van de industrièle ontwikkelingen vormde een stimulans voor wat later het beroep van zelfstandig architekt zou worden. Het Amsterdamse adresboek vermeldt in 1853 een antal

"beoefenaars van de bouwkunst" van zegge en schrijue 8 , een antal dat dertig jaar later, in 1883, was angegroeid tot 103.

Toch kwam enige matschappelijke erkenning maar moeizaam op gang. Ter illustratie diene het relas uit 1884 van het konflikt tussen de zécr gerenommeerde architekt prof. Eugen H. Guge1 (* 1) (waarover later meer in hoofdatuk II.2) en de eveneens zeer vermaarde oprichter van de Koninklijke Nederlandse Gist-en Spiritusfabriek, ir. J.C. van Marken, een in social opzicht zeer vooruitstrevend man, rond het honorarium voor de bouw van diens villa "Rust Roest" te Delft. Daarbij werd een niet te onderschatten rol gespeela door aannemer Den Braanker en opzichter Kerckhoft. Den Braanker was nota bene een hoogst achtenswaardig ild van de Matschappij tot Bevordering der Bouwkunst! (* 2 ).

De briefwisseling over de hoogte van Gugel's deklaratie (die in relatie met de Duitse en Franse traditie volkomen en régle was. Nederlandse standaardnormen waren er eenvoudig niet) laat $z i$ en in welk een ondergeschikte positie een man als Gugel zich bevond. Hem werd eenvoudig de deur gewezen op een keurig geformuleerde, maar stuitende wijze. En passant werden hem nog prijsoverschrijdingen a angewreven waran hij part noch deel had, mar die uit de innige verhouding tussen opdrachtgever en annemer voortaproten. Wie werd hier als "bouwmeester" gezien? De juridische traditie volgend, erder de annemer dan de architekt. Terecht klagde Gugel over de miskenning van het beroep, die een fatgoenlijke honorering belette, en stelde hij

"dan bliff ik op het stuk van geldverdienen toch een ellendige sukkelaar en stumper tegenover Den Braanker (aanneme- - ), die met niets te doen en zonder risico 10. honorarium trekt en door onder-aanbesteding en aan materialen enz. nog $5 \%$ à $10 \%$ erbij!"

Vooral uit de latste opmerking blijkt dat de annemer feitelijk geen relatie had met de ambachtelijke kanten van het vak, en dat deze dat overliet an de ambachtslieden. In 
de historische ontwikkelingen tot 1850 is reeds duldelijk gemakt dat na de afschaffing van de gilden, de annemer ontstond als koördinator van ambachten bij de uitwoering van werken, mar dat hem in feite de kennis van de bouwkunde ontbrak. Vooral in architektenkringen werd deze koppelbazerij met grote minachting bejegend.

Natuurlijk ontstonden met deze groel alle kollegiale- en betoepsproblemen die ook thans nog een rol spelen, getuige tenminste de opmerking in een artikel dat zij "ellkander soms lauweren betwisten en vliegjes afvangen" (t 2 ). De onderlinge konkurrentie onder de vakbeoefenaren loog er overigens niet om, zoals blijkt uit De "Opmerker" van $16-12-1884$ :

"de scherpe concurrentie tegenwoordig door de architekten onderling gevoerd, is oorzak, dat velen behalve door laag tarief, ook door groote betalingsfaciliteiten klanten trachten te lokken en daarom nimmer van betalingstermijnen spreken".

Dat die konkurrentie niet beperkt bleef tot vakbroeders onderling blijkt uit een andere publikatie in hetzelfde blad omstreeks dezelfde tijd. Het ging daabijom de architektenkeus voor de bouw van de nieuwe kerk van de H. Bonifacius te Amsterdam warbij ook een gemeenteambtenar gratis zijn diensten anbood aan het kerkbestur. Deze konkurrentie deed het aanzien van het becoep geen goed. Tekenend voor de situatie is, dat de in 1842 opgerichte Matschappij tot Bevordering der Bouwkunst bij de oprichting bestond uit allerlei vertegenwoordigers van het bouwvak en daarbuiten, $t$. w.: bouwkundigen, aannemers, leveranciers en belangstellenden. De kwalificatie

"architekt" ontbreekt hier: zoalls wij al eerder zagen komt volgens Bruynzeel (* 3 ) het woord "architekt immers in de geschreven Nederlandse literatuur van vobr 1850 mar énmal voor. De geringe maatschappelijke waardering voor het architektenberoep zal zijn oorsprong hebben gevonden in de onbekendheid met de architekt in een onafhankelijke positie. Deze architekt moest $z$ ijn status nog verwerven. Daarbij kan een beroepsorganisatie van grote warde $z y^{j}$, maar pas in 1908 wordt de "Borid van Nederlandsche Architecten" opgericht als vereniging van architekten (zie hoofdstuk II.1.3).

Uiteraard gat de Bond onmiddellijk aan de slag poor de rechtszekerheid van de architekt door middel van beroepsof titelbescherming.

De vraag over de beroepsbescherming was in 1900 al aktued. zoals blijkt uit stelling $x x$ van Bruynzel's dissertatie: "het vraagstuk der volkshuisvesting is voor geen goede oplossing vatbar, tenzij de bouwerordeningen ook in die zin worden gewijzigd dat voor het bouwen anders dan volgens plannen ontworpen door gediplomeerde deskundigen, geen verguning wordt verleend ${ }^{\text {HI }}$. 
In zifn antwoord op het hierdoor uitgelokte kommentaar halt Bruynzeel mx. Verkouteren an (*4) die in zijn brochure "De Woningwet" vraagt:

"warom is iedereen bevoegd $z$ ich als architekt op te werpen, terwijl niet iedereen de geneeskunde mag uitoefenen? slechte bouwmeesters brengen, evengoed als onbevoegde geneeskundigen, menschenlevens in gewar. Het beroep van bouweester moet niet langer een volkomen wij beroep zijn, al behoeft de beperking nu juist niet altijd in theoretische examens te worden gezocht".

Reeds véél eerder (1891) had mr. Verkouteren zijn sympathie voor de titelbescherming getoond. In zijn visie zou daardoor na invoering zelf $\mathrm{E}$ de gemeentelijke bouwergunning tot het verleden kunnen gaan behoren (* 5).

Het waren vooral de onbekwamen en de athankelijken die het beroepsbeeld van de architekt verstoorden. Echter, een wettelijke beperking van de bevoegdheld tot hen die een diploma bezaten of nog zouden verwerven riep zelfs bij respektabele vakgenoten de nodige twijfels op.

In een lezing gehouden op 17 februari 1864 door de heer Daniël J. Sanchez, een man met bekendheid in die dagen, makte deze melding van een bericht van Jules Bouchet, direkteur van de Revue Générale de l'architecture et des travaux publics, en makte een balans op van voor- en tegenargumenten (*6). Vóor de titelbescherming pleitte het gebrek an kwaliteit van de toenmalige architekt, terwijl diens integriteit ook niet boven elke twijfel verheven was: "laat een bas-relief, eene gravure, eene symphonie, eene schilderij minder geslaagd zijn, dan wordt daardoor nóch de gezondheid, noch het leven, noch het fortuin van iremand benadeeld, terwijl daarentegen een gebouw, dat slecht gelegen, slecht geordonneerd, slecht bestudeerd in zijne onderdelen is, al deze rampen na zich kan slepen. Bovendien is de eigenaar dikwijlat het slagtoffer van de te naauwe betrekking tusschen den architect en de aannemer; want men moet niet uit het oog verliezen dat de wansmak en de onwetendheid alkwijls hand in hand gaan bij hen die zich den hun onwardigen titel van architect toeẻigenen.

Bij het tegenwoordig stellsel, maken de architecten die op de hoogte van hun vak $z i j n$ de minderheid uit; het bewijs hiervoor vinden wij in het groot antal misvormde constructiën der buitenwijken van Parijs, war zelfs de grondbeginselen worden miskend"

- aldus het door sanchez gehanteerde cital van Bouchet.

Het feit dat in de Hollandse diskussie deze stellingname zo expliciet ten tonele wordt gevoerd, doet vermoeden dat de situatie nier te lande niet veel anders zal zijn geweest. 
Sanchez zélf deelde Bouchet's mening over beroepsbescherming overigens allerminst. Vit zijn kommentaar bilijkt dat er in die tijd twee "typen" architekten opereerden: n.1. de "Akademisten" (de Akademie in Delft was toen net polytechnische school geworden) en de "practici" , warbij, de eersten "van de praktijk niets weten; die een plan wel kunnen ontwerpen, maar niet uitvoeren". We zullen later zien dat deze stelling veel wars bevatte gezien de stand van het toenmalig bouwkundig onderwijs. Maar Sanchez bezwaren hadden toch meer een politiek-maatschappelijke achtergrond:

"men makt een gilde van haar, (het vak van architekt -F) iets dat geheel en al tegenstrijdig is met onze eeuw van vrijheid, stoom (I) en vooruitgang. Slechts het publiek is regter en zijn oordeel is regtvaardiger en onpartijdiger dan dat van een akademie....".

Dit standpunt draagt kenmerken van het opkomend

liberalisme, van afkeer van kartelvorming (het gildewezen was pas 60 jaar daarvoor afgeschaft) alsook van de controverse tussen de theoreticus en de praktische ambachtsman.

Menig groot projekt van rond de eeuwwisseling draagt de sporen van dit verschil in typen architekt. Het geringe konstruktief besef bij de "grote" vormgevers van toen heeft onder andere tot de huidige afbraak van de cuypers kerken geleid.

Dat de regering niet helemal ongeinteresseerd was in een bescherming van de architektentitel blijkt uit het feit dat zij dr. P.J.H. Cuijpers als gedelegeerde zond naar het internationale architectencongres in parijs dat in 1900 werd gehouden. Cuijpers rapporteerde de algemene insteming van het congres met het beginsel van titelbescherming. zijn verslag werd opgenomen in de statscourant van 28-12-1900 nr. 303. Met de langzame groei van het matschappelijk belang van de architekt neemt echter ook de belangstelling van die zijde voor titel-en beroepsbescherming toe, warbij ook naar de ontwikkelingen over de grenzen werd gekeken.

De "Opmerker" van 1905 bevat een opgave van de situatie in Europa en de Verenigde staten die is weergegeven op blz.37 Rond 1910 werd ook in de Verenigde staten de scheiding tussen bouwondernemer en architekt door middel van beroepsbescherming een feit. Aanleiding daartoe waren de misstanden en troebele verhoudingen tussen deze beiden die aan de dag traden bij de explosieve groei van de stad Chicago. Duits kommentaar op dit gebeuren meldde verheugd dat daarmee de architektenstand werd verheven tot die wan advokat of geneesheer" (*7).

Een climax in de ontwikkeling van de titel-/beroepsbescherming werd bereikt rond 1925 . Op 18 april wan dat jaar werd op de ledenvergadering van de BNA het rapport behandeld dat was uitgebracht door "de comissie Wettelijke 
Bescherming van den Architectentitel". Over de wengelijkheid was vrijwel iedereen het toen eens: 40 stemmen vóor en 5 tegen.

Er waren twee bezwaren:

1 het examen al beoordeling van de vakbekwamheid;

2 het ontbreken "eener voortreffelijke opleiding".

De bezwaren tegen het examen lagen voor de hand: te fragmentarisch en ook te theoretisch. Over de opleiding bestond geen duidelijk beeld. De gewestelijke kringen werden uitgedaagd om met woorstellen te komen, hetgeen. geen enkel gevolg had. Het Besture was niettemin van mening dat de opleiding "zoo opvallend achterstond" dat een inhalmanoeuvre diende te worden uitgevoerd.

Ir. G. Friedhoff schreef in 1925:

"ik voor mij beschouw bescherming van het architectenberoep in principe als de enig goede oplossing, doch wil dit punt verder laten rusten daar wij daar nog lang niet aan toe zijn en de bescherming van den titel een schrede in die richting is, welker verwerkelijking meer binnen het bereik zal liggen".

Als Wettelijke Bepalingen werden aanbevolen de instelling van een wettelijke Raad ter opening van een register voor hen die als architekt wensten te worden ingeschreven. Na een overgangstermijn van 6 maanden zou niemand de titel van architekt (of bouwmeester) mogen voeren, tenzij hij in het Register was ingeschreven. In aanmerking zouden komen naukeurig gespecificeerde gediplomeerden of praktijkmensen. Ook het architektenexamen zou nauwkeurig geregeld worden, terwijl ook de titel "honoris causa" moest kunnen worden verleend.

Wat er met de voorstellen is gebeurd is onduidelijk. Vier jaar later, in 1929, wordt door de BNA een adres verzonden ( 16 december) aan de toenmalige minister van onderwijs, Kunsten en Wetenschappen, Terpstra. Bij de begrotingsbehandeling van 20 december 1929 in de Tweede Kamer heeft het kamerlid dr. Moller de andacht op dit adres gevestigd. Een ernotige bestudering werd door de minister toegezegd. In de Kamerzitting van 20 december ondersteunde ook ar. Th.J. van der waerden nog eens het BNA-gtreven, maar diens pleidool voor het instellen wan een stadtskomissie ter bestudering vain thet BNA-voorstel werd door de minister terzijde gelega. Hij stelde dat het interdepartementad overleg nog gaande was over de vraag of de architektentitel wel integraal dilende te worden ingevoerd (* 8 ).

Ook in kringen van raadgevende ingenieurs en civielingenieurs trok het vraagstuk belangstelling.

vitvoerig ging jhr. A.H. Opten Noort in een pre-advies in op de problemen die het gevolg waren van het uitblijuen van de bescherming (* 9). In het naschrift van dit artikel hast ir. A.J. van der steur zich om duidelijk te maken 


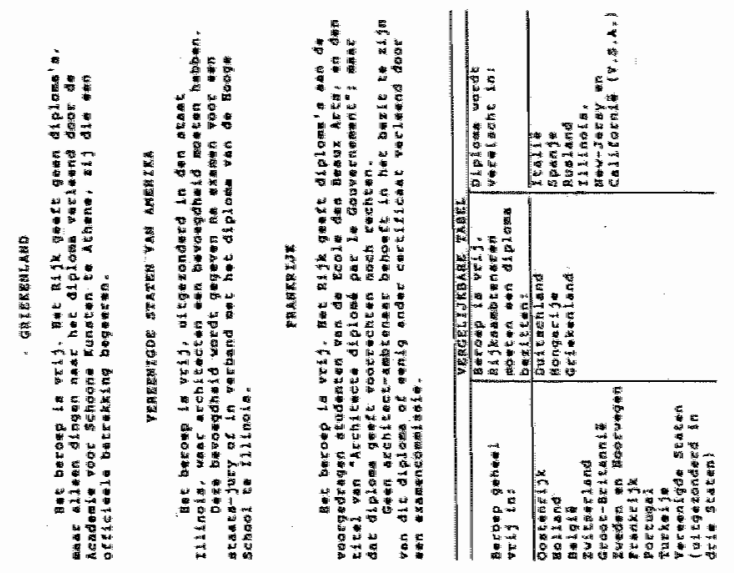

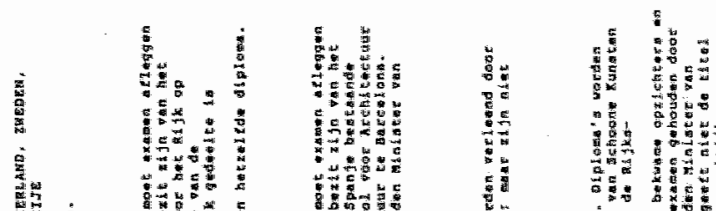

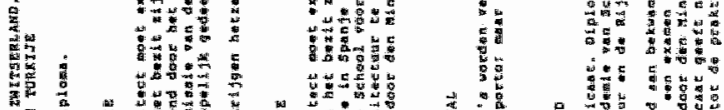

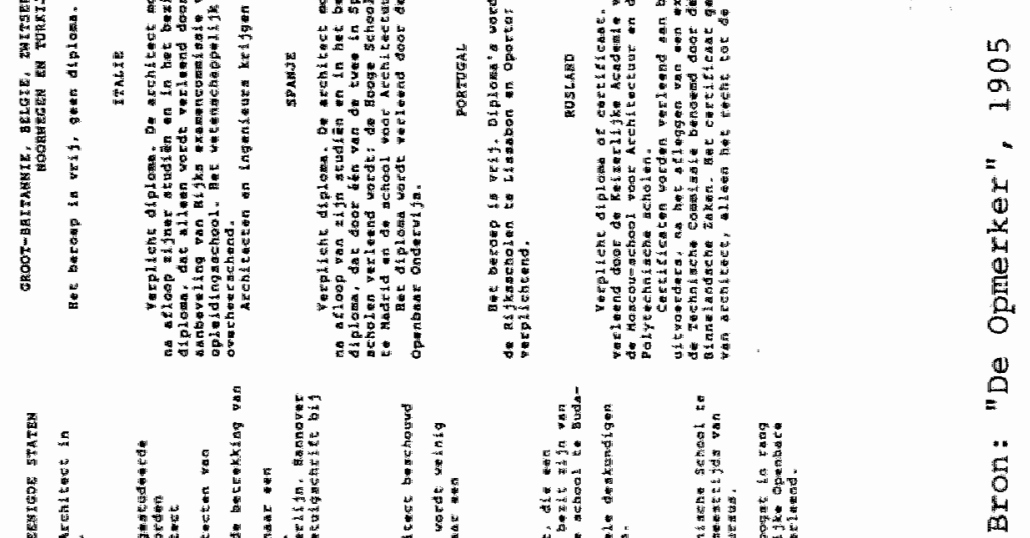

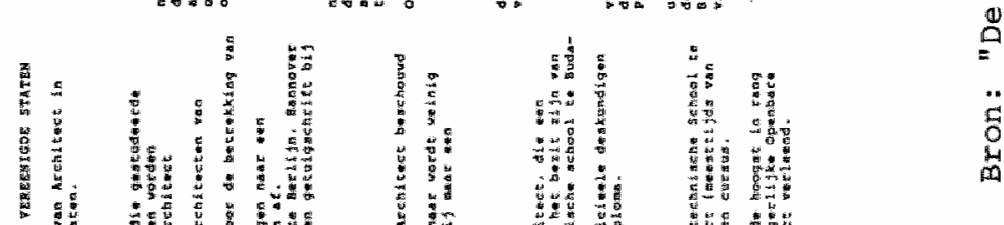

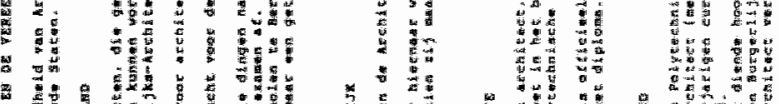

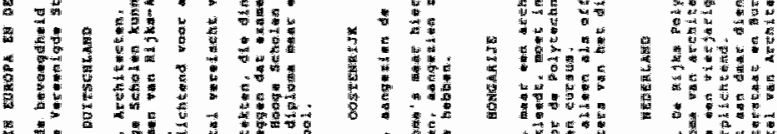

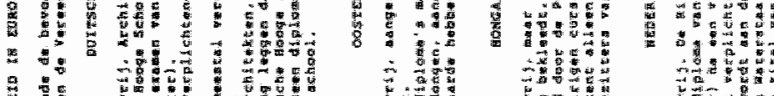

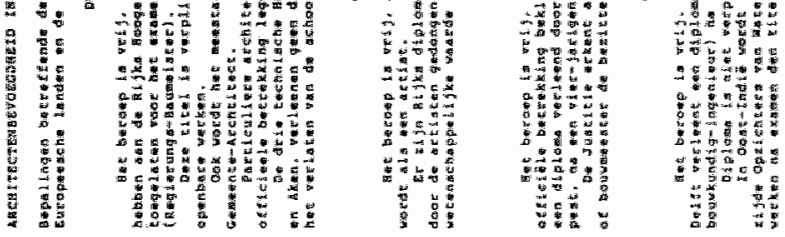


"dat alleen aan den werkelijk deskundigen civiel-ingenieur (als architekt) zeker de titel van architekt niet ontzegd mag worden, war de overigen....". Marmee aangetoond is dat het aangeven van de grenzen wan de bevoegdheid toen al even moelijjk was als nu.

uiteindelijk neigde men ook toen, terwille van het voorkomen van onnodige vertraging als gevolg van hachelijke grensgevechten, allengs meer nat een titelbescherming in plats van beroepsbescherming.

De opvolgers van minister Terpatra hadden schijnbaar belangrijker zaken aan het hoofd, en de beroeps-en titelbescherming van de architekt bleef in de bureaula tot 1940. Het versiag van de begrotingsbehandeling voor het Departement van Kunsten en Weterischappen van 1939 meldde dat de minister positief denkt over de titelbescherming van de architekt.

In december 1939 worden hem daarover nog nadere vragen gesteld, warop minister Bolkestein opnieuw het kulturele belang erkent van de beschermde architektentitel. Het ultbreken van de Tweede Wereldoorlog verhinderde echter de verdere parlementaire ontwikkeling tot wet.

Na de Tweede wereldoorlog la aide de diskussie opnieuw op. zoals in hoofdstuk IV nader zal worden uiteengezet. 
II.1.2

de opleiding voor het architektenberoep

De matschappelijke waardering voor het architektenberoep is sterk gerelateerd aan de kwaliteit van zijn dienstverlening. Er is derhalve een duidelijke samenhang tussen de kwaliteit van de opleiding, de daarmee verbonden kwaliteit van de beroepsuitoefening en de matschappelijke bereidheid om de bevoegdheid tot het uitoefenen van het beroep tot de goed opgeleiden te beperken.

Dat over een goede opleiding tot architekt de wildste ideeën de ronde deden moge blijken uit de woorden van de architekt Cluysenaer, een Belg die in 1868 (* 10) bewees "met cijfers, dat doar een volledige cursus, van het begin tot het eind gevolgd door den akademische leerling een architekt is voort te brengen in even zooveel uren tijds als gelijkstaan met 120 werkdagen". Een snelle ontwikkeling derhalve! De sleutel voor deze stelling zal wel gelegen zijn in cluysenaers' definitie van een architekt. Gellukig waren er ook bezonkener benaderingen. De kern van het vak wordt uitstekend geschetst door Louvet in zijn " 1 'Art de 1 "Architecture et la profession de 1"Architecte" (*11). "la profession des qualités artistiques indispensables à l'architecte, celle qui le distingue du simple constructeur, c"est d̀ dire 1"art de placer les différentes parties d"un ensemble d'une façon à la fois raisonneé, à droite et agréable et d'une régler les proportions. Il y a sans doute bien des elements de l'art de la composition: il $y$ faut beaucoup de bon sens, de la mesure, de la logique, du goût, mais ces qualités ne suffísent pas et il est indispensable d"y ajouter un sens artistique développé par une longue étude et par un exercise constant".

De studie voor de architect bepalde zich (rond 1850) nagenoeg geheel bij "het nateekenen en pijnijjk opmeten van de vijf bouworden" aldus KIinkhamer in zijn gedenkschrift van de Polytechnische school (* 12). Hij doelde daarmee op de eenzijalgheid van de studie die $z$ ich voornamelijk bepalde tot een diepgaande orientatie op de klassieke en oude architektuur. De bouwkundigen Van Dam, Heynincx en Warnsinck, leden van de Koninklijke Akademie van Beeldende Kunsten richtten op 28 december 1841 een adres a an de Minister van Binnenlandse zaken met het verzoek om oprichting van een "incichting voor onderwijs voor Bouwkundigen" in relatie met de Koninklijke Akademie te Breda. In 1843 werd in Delft de Konjnklijke Akademie opgericht (ingenieursschool) en "de Bouwkunst" werd opgenomen onder de te doceren vakken. Er kwam dus géen zelfstandige opleiding.

Bouw- en Beeldhouwkunst werd rond 1840 gegeven aan de Akademies te Amsterdam, Rotterdan, Den Haag, Den Bosch en van Rijkswege ("mar niet veel beter" aldus Klinkhamer) te Breda en Delft. 
Vooral het achterblijven wan de ambachtelijke zijde van het vak werd door de goede vakgenoten als een manco gevoeld. coed onderwijs in de bouwkonstruktie was er niet en zij die dat voor hun vorming essentieel achtten gingen naar Antwerpen, Hannover, Parijs, Berlijn of Rome. Het ontbreken van de synthese van kunst en techniek in de vakopleiding van de architekt belemmerde een zelfstandige matschappeilijke positie van de architekt naast de annemer.

Eerst in 1861 werd er een leraar Burgerlijke Bouwkunde benoema an de Koninklijke Akademie te Delft, speciaal voor de boumkonstruktie (G.J. Morre). Verzet van de studenten, voornamelijk tegen het straffe en eenzijaige studiesystem, leidde tot de sluiting van de Koninklijke Akademie de overgang nat de Polytechnische School in 1863, hetgeen als een degradatie werd beschowwd naar het middelbar onderwijs. De hoogleraren die mee overgingen natr het nieuwe systeem bleven evenwel, wellicht als pleister op de wonde, de titel van professor behouden. De afdeling Bouwkunde werd één van de vijf studierichtingen waraan, bij gebrek aan hollandse docenten van format, verscheidene buitenlanders als hoogleraar hun bijarage leverden. Het is Thorbecke geweest die de stoot gaf tot de benoeming van de toen 32-jarige Duitser Eugen H. Gugel tot lerar aan de Polytechnische School in 1864 en later hoogleraar a an de Technische Hogeschool Delft. Aan deze man heeft het bouwkundeonderwjjs heel veel te danken, hij heeft 38 Jaar aan het hoofd gestaan van de afdeling. Tot 1878 stond Gugel zelfs alléen voor het onderwijs in de architektuur. De bouwkunde-studie was gekoppeld a an Weg- en Waterbouwkunde zodat de meeste van Gugels talloze leerlingen niet bouwkundig. mar civiel ingenieur werden. of het belang van de kunst óf de techniek in de vakopleiding moest prevaleren, was ook toen de belangrijkste vraag. Vandar dat sommigen de Delftse opleiding afwezen en vonden dat de Akademiën deze taak moesten vervulien. Toch bleef de opleiding te Delf en bereikte in 1905 met de omschakeling naar het Hoger onderwijs een universitair niveau.

Dat de Polytechnische school niet bepald als een architektenfabriek fungeerde blijkt uit het feit dat er in 1899 één kandidaat was voor het eindexamen, in 1900 niet Gen en in 1905 weven. De kursus 1904-1905 telde 30 atudenten in total.

Met de optichting van de Technische Hogeschool in 1905 werd de basis gelegd voor een evenwichtige ontwikkeling van de opleiding met betrekking tot de synthese van kunst en techniek.

De inhoud van het studieprogramma bleek, ook toen al, een punt van diskussie. Het rapport van de "Centrale Commissie voor de studiebelangen aer Studeerende an de Technische 
Hogeschool te Delft" van december 1907 (* 13) bevat een antal wensen ten aanzien van het studieprogramma, te weten:

- aparte kolleges wis- en natuurkunde:

- meer kolleges architectuurgeschiedenis, kunstgeschiedenis, kunstnijverheid en ornament:

- meer kolleges in de geschiedenis der Bouwkonstruktie:

- instellen van kolleges stedenbouw, Bouwtechnische Hygiëne en Bedrijfsleer.

Voorts:

- grotere onafhankelijkheid van de civiele vakken:

- uitbreiding van de studie met de moderne toepassingen der esthetica in de praktijk;

- een groter verband tussen de vakken onderling.

Door diskussies van deze aard groeide de synthese tussen techniek en vorm in de opleiding verder uit als een akademische opleiding na een theoretische vóóropleiding. Friedhoff pleit in 1925 (* 14) nog voor het zweedse systeem dat liep van Ambachtsschool tot en met de Rijksakademie en dat er als volgt uitzag:

ABS (Ambachtsschool)
HBS 3 jaar
HBS 5 jaar
Praktijk
MTS
Plaatselijke Akademie
TH afd. MTS
TH afd. HBS
TH 3e en 4 jaar
Praktijk
Rijksakademie

\begin{tabular}{|c|c|c|c|c|} 
A & B & C & D & $\mathbb{E}$ \\
3 & 3 & - & - & - \\
- & - & 3 & 3 & - \\
- & - & - & - & 5 \\
- & - & 1 & 1 & 1 \\
3 & 3 & 3 & 3 & - \\
- & 2 & - & 1 & - \\
2 & - & 1 & - & - \\
- & - & - & - & 2 \\
2 & 2 & 2 & 2 & 2 \\
1 & 1 & 1 & 1 & 1 \\
2 & 2 & 2 & 2 & 2 \\
\hline 13 & 13 & 13 & 13 & 13
\end{tabular}

In hoeverre dit voorstel heeft doorgewerkt naar de Akademie opleidingen is niet te traceren. Als integraal opleidingsidee, gekoppeld aan de praktijk, is het een interessant gegeven. Het betreft hier een vijftal opleldingstrajekten van elk 13 jaar totaal. Het einddoel kon op verschillende manieren worden bereikt. Via de praktijk (A en B - ABS. MTS, TH, Akademie) of via een theoretische onderbouw (C, D en E-HBS, MTS, TH, Akademie). Zorgvuldig waren in beide hoofdstystemen praktijkjaren ingevoegd waar zulke nodig was: in de theoretische opleiding meer dan in de andere. Beide hoofdstystemen kenden een tweejarige afsluiting aan de Akademie, die voornamelijk op de vormgevingsaspekten van de opleiding was gericht. Als curiositeit zij nog vermeld dat thans in de bouwkunde-onderwiljproblematiek van de jaren 1985-1990, voorstellen circuleren die eveneens voorzien in een technisch/theoretische le fase (MTS-HTS-TH) en een vormgevende $2 \mathrm{e}$ fase (Akademie van Bouwkunst) als synthese tussen Hoger Beroeps- en Wetenschappelijk 
Vanaf de dertiger jaren kan worden gesproken van een evenwichtige opleiding tot architekt an de Technische Hogeachool te Delft, warin dus recht werd gedaan aan de binding van de architektuur-als-kunst en an de technische realiatie

II. $1 \cdot 3$

de architekt in organisatorisch verband

Na de oprichting in 1842 beijwerde de Matschappij tot Bevordering der Bouwkunst zich, niet alleen voor de titelen beroepsbescherming, mar vooral voor het architektonisch ontwerpen en het ambachtelijk onderwijs in de bouwkundige vakken. In een artikel van zijn hand meldt

dr. M.P. van der Linden (* 15$)$ dat ook sociaal-ekonomische onderwerpen in de belangstelling stonden. Een van de eerste rapporten van de Matschappij handelde over het drankmilaruik onder de werklieden.

Het 1 idmatschap was niet alleen aan architekten voorbehouden. Een statje van de samenstelling van de leden in 1908 geeft darvan een voorbeeld:

architekten

ingenieurs

studenten $\mathrm{TH}$

leraren

sierkunstenaars en kunstnijveren 11

bouwkundigen, opzichters, tekenaars 111 a annemers

fabrikanten (bouwmaterialen etc.) 52

bouwkunstverenigingen, akademies 18

agenten in bouwartikelen 22

beoefenaars van de bouwvakken 31

diverse belangstellenden

Er beatond een rangonderscheid onder de leden, de ene groep betalde meer kontributile dan de andere. zo waren er ereleden, gewone leden, buitengewone leden en "kunstlievende" leden. Voocal de social-ekonomische gerichtheid van de Matschappij onderscheidde har van een verwante organisatie: het Genootschap Architectura et Amicitia (opgericht in 1855). Datzelfale element bleek een splijtzwam binnen de gelederen. De behoefte aan een beroepsorganisatie onder de architekten leidde tot een breuk die de Bond van Nederlandse Architecten deed ontstaan. Deze organisatie werd opgericht op 29 februari 1908. De diskussie die toen werd gevoerd door de leden van de nieuwe Bond, over de statuten had wel tot resultat dat de organisatie niet slechts een vakbond van architekten werd: ook de bouwkunst werd als matschappelijk en kultureel element een van de andachtspunten. 
Lang niet alle architekt-leden van de Matschappij waren overgegaan naar de BNA, sommigen waren van beide organisaties lid. De uittocht van dissidenten zorgde voor een omgekeerde diskussie in de Matschappij: de noodzaak om meer een beroepsorganisatie te $z i j n$ dan voorheen was duidelijk voelbaar. Die ommezwai was heel wat lastiger: het ledenbestand van de Maatschapplj was zeer veelkleurig. Uiteindelijk werd via een stemrecht-regeling voor "gewone" leden na het nodige geharrewar een kompromis bereikt.

De beide verenigingen bestonden, met bijna gelijke doelstellingen, naast elkaar voort. De Maatschappij deed nog een stapje in de richting wan een beroepsorganisatie door de naamswijziging in 1915: Matschappif tot

Bevordering der Bouwkunst Vakvereniging van Architecten (M.B.V.A.) In 1919 besloten de beide verenigingen om weer samen te gaan, nadat er jarenlang was gediskussieerd. Er waren toch teveel bindende elementen om een scheiding te rechtvaardigen.

In de 10 jaren van zelfstandigheid heeft de BNA veel tot stand gebracht o.a.:

- de oprichting van de Vereeniging voor Voortgezet en Hooger Bouwkunst onderricht (in samenwerking met Arti et

- Amicitia) - 1915

- het adresseren aan overheden inzake monumentembescherming

- aanbod tot assistentie bij de keuze van architekten voor Rijksgebouwen - 1913

- het bepleiten van opneming van welstandstoezicht in de bouwverordening via een adres aan de Vereniging voor Nederlandse Gemeenten - 1913

- diverse akties tot bevordering van de keuze van partikuliere architekten door averheden - 1909, 1915

- het publiceren van de AAV - 1915

- het aangaan van een kollektief arbeidskontrakt met de Bond van Technici - 1910

- het vaststellen van "Algemeene Nederlandsche Prijsvraagregelen"t - 1910

- het herzien van de honorariumregeling (in samenwerking met de MtBB.) - 1915

II. 2

De aannemer

II. 2.1

de aannemersstand

In een matschappelijke beschouwing over het architektenberoep kan een visie op de aannemerij in deze periode niet ontbreken. Zoals wij reeds zagen (I.2.4) heeft het

funktioneren en de mate van matschappelijke acceptatie van de annemer grote invloed gehad op de status van de architekt. Bovendien was de architekt de belangrijkste tegenspeler van de annemer, althans in de burgerbouw war de opdrachtgever terzake onkundig werd geacht te zijn. 
Wa de architekt rond de eeuwisseling een omstreden instituut, de annemerij was dat niet minder. Het versiag van de 9 e Algemene Vergadering van de leden van de Watschapplj tot Bevordering der Bouwkunst in 1863 , bevat ean uitvoerige weergave van de diskussie rond punt 4 van de agenda: "is de a annemersstand in het algemeen gunstig te achten voor de bouwkunst, de bouwheren, de architekten, ambachtabazen en werklieden"? Ter verduidelijking moet hierbij worden vermeld dat náást de aannemerij-in-opkomst nog volop de zogenaamde "daghuur" in zwang was. Daarbij werden de onderschelden beroepsgroepen voor de onderdelen van het werk ingehuurd en de koördinatie werd verzorgd door de meester-timmerman.

De tegenstellingen waren al bijna honderd jaar oud (* 16), zij het op 1 iets andere schal en kwamen erop neer dat de a annemer primalr het gewin nastreefde en de ambachtsman in daghuur de kwaliteit van het werk bepaalde.

De schriftelijke bijarage an de diskussie van de hand van zekere $P$. Quant werd integral in het verslag opgenomen:

- voor bouwkunst : vóór, want er waren op die wijze reeds zeer vele fraaie bouwwerken tot atand gekomen ( $w .0$. postkantoor Amsterdam) ;

- voor bouwheren tegen, kwaliteitswerlies.

- voor bouwheren

- voor architekten

- voor ambachtsbazen

- voor werklieden
: voor, geen administratieve en financiële rompsiomp, de laagste prijs, het beste werk en de kortste bouwtijd:

: vóór, want besteden maakt een goede planvoorbereiding noodzakelijk en dat betekent werk voor de architekt (bij daghuur werd namelijk meestal zonder architekt gewerkt) tégen, lagere bouwsom, dus minder verdiensten: ler werd idealiter afgerekend tegen een vast percentage zonder verrekenbare eenheden):

verdeeld; vóor pleit het ontbreken van Einancieel risiko en de integratie op het bouwwerk: tegen, het verlies van werk aan de aannemerij en de toenemende onderlinge konkurrentie:

- vóór, toename van werk van de aannemer betekent toename van werkgelegenheid voor de werkman. (of dat ook resulteerde in meer welvart was nog de vraag. Er werd blijkens het verslag nogal eens onderbetaald). Promotiekansen bij goede vakbekwamheid.

De algemene vraag was of het aanbesteden zoals dat in zwang kwam, dus integraal verscheidene ambachten omvattende, wel 
"redelijk" was te noemen. Die vraag was niet zo vreend als het wellicht lijkt. De annemer vergiste zich nogal eens, al dan niet veroorzakt door:

"onvolledige bepalingen, bestekken of gemis aan

detailtekeningen, ofwel door wat luchtige aanijzingen door de architect, of door gemis an genoegzame bekwamheid bij de concurrenten".

De gewoonte van a anbesteden bij opbod kon in elk geval geen enkele genade vinden in de ogen van een andere referent, een zekere smit, omdat daarbij ook nog op de "hartstogten" werd gewerkt. Aldus nog steeds het verslag van de $9 e \mathrm{Alg}$. Vergadering van de Matschappij.

II. 2.2

eigembouw en revolutiebouw

In de tweede helft van de negentiende euw is ex nog een fundamentele verandering opgetreden aan het bouwfront voor wat betreft de aannemerij, namelijk de overgang van de bouwproduktie op bestelling nar de produktie voor de markt op het stuk van de woningbouw. Het is dan dus niet alleen de particuliere opdrachtgever die het initiatief neemt. Deze overgang, welke zich ook elders in de wereld voltrok, vindt volgens Van der Wal (* 17) zijn oorsprong in de plotselinge snelle bevolkingsuitbreiding van de grote steden en de industriecentra. Dit was weer het gevolg van de opbloei van handel en industrie die een grote vraag naar woningen deed ontstaan.

Hoe groot die vraag was blijkt uit het rapport dat uitgebracht is door de commissie van onderzoek van de Amsterdamse Gemeenteraad in 1897, over de toestand van de werklieden in de bouwbedrijven te Amsterdam. 'Zij

rapporteerde over het inwonertal van de hoofdstad:

$1750-217.024$
$1800-200.430$
$1850-217.000$
$1870-235.000$
$1880-278.337$
$1890-349.591$
$1900-495.000$

Amsterdam groeide ten opzichte van 1830 met 144 , Den Hag in aiezelfae periode 241\%, Rotterdam 296\%, Arnhem 280 omat er vóór 1850 een woningoverschot was is de grote woningbouwproduktie pas rond 1870 op gang gekomen. Ook Engberts verwijst hiernaar in zijn proefschrift (* 19).

Het totaal aantal woningen in ons land vermeerderde van 1856 tat 1868 met ca. $15 \%$ en tot 1882 met ca. $36 \%$. In de grote steden bedroeg die aanwas van woningen respektievelijk $32 \%$ en $70 \%$. In de jaren 1920 - 1933 herhalde deze situatie zich. De vermeerdering van de in ons land aanwezige woningvoorrad was veel groter dan de bevolkingstoename: $36 \%$ tegenover $28 \%$, in de grote gemeenten 
stimulering van de woningbouw van overheidswege kwam toen niet voor. Wél werd de werkingssfeer van de bypotheekbanken na 1850 uitgebreid wabraor de kredietfaciliteiten voor de amnemer werden verruima. Bovendien ging door de stijgende woning van 7 in 1843 nate 4,76 in 1882 (* 19).

De hang van het publiek nate beleggen in onroerend goed gaf de bouwbedrijven de wind in de zeilen. De marktsituatie had evenwel ook een sterke aantrekkingskracht voor lieden met minder goede principes, de "revolutiebouwers". Interessant is in dit verband de visie van het al eerder aangehaalde gemeenteraadsrapport van 1897 :

"Wat de kwaliteit hunner, producten aangaat, moeten aan den eenen kant gerangschikt worden de aannemers en de goede eigenbouwers, aan de anderen kant de revolutiebouwers. De grensiljn tusschen goede eigenbouwers en revolutiebouwers is natuurlijk zeer moeilijk te trekken. De aannemer werkt met eigen of opgenomen kapitaal, maar draagt zelf in ieder geval het risico van den bouw. Zijn bestek dwingt hem tot het opleveren van een gebouw dat an bepalde eischen moet voldoen; dit levert dus meestal eenigen warborg ten opzichte van de kwaliteit van het gebouwde en daarenboven is hij aan $z i j n$ goeden naam verschuldigd zijne financieele verplichtingen tegenover zijn crediteuren en zijne arbeiders na te komen; gelukt hem dit niet, dan heeft hij zijne positie verloren. De goede eígenbouwer. meestal een timmermanspatroon, heeft voor een goed deel dezelfde belangen bij een vrij deugdelijken bouw als de annemer. De koopers zijner huizen zullen well degelijk letten op de kwaliteit van het gebouwde. ook hij heeft eene reputatie op te houden ên als aannemer én als burgerbaas.

Al deze warborgen $z i j n$ bij den revolutiebouw afwezig. Hij bezit zelf in den regel geen middelen; hij heeft geen handelsreputatie op te houden. Wat de kwaliteit van den bouw betreft, is hij a an niemand verantwoording schuldig. En ook zijn financieel belang zet hem niet an tot het bouwen van woningen van goede kwaliteit, daar de zeer kleine kapitalisten die zijne huizen koopen, het met die kwaliteit niet nauw nemen. De wijze, warop het proces van den speculatiebouw verloopt, kan dit duidelijk maken. In de meeste gevallen is het niet de bouwer zelf, die het initiatief neemt tot den bouw. Hij wordt tot bouwen angezet door grondspeculanten of door vertegenwoordigers van hypotheekbanken. De grondspeculant heeft van de gemeente of van een anderen grooten grondeigenaar een vrij uitgestrekt bouwterrein gekocht en wil dit in perceelen zoo voordeelig mogelijk van de hand doen. Van den 
revolutiebouwer nu kan hij een prijs maken, die door een onafhankelijk persoon niet zou zijn betald. De hypotheekmatschappijen wenschen niets liever dan hat crediet te verleenen tegen hooge belooningen. Risico bij dit verbond loopen noch grondspeculant noch hypotheekmatschappij, noch de bouwer zelf. De credietmatschapij toch verleent slechts zooveel crediet, als door de krap begroote warde van thet gebouwde wordt gedekt. Zij verbindt zich alleen tot het verstrekken van zooveel geld in termijnen als zij telkens na taxatie van het gebouwde zal goedvinden te geven. Bij executie derhalve van het gebouwde is de credietgever bijna altijd zeker zoveel terug te ontvangen, als hij aan crediet heeft uitbetaald en de grondeigenaar is de eerste, die door den bowwer wit de ontvangen sommen wordt betaald.

De bouwer zelf kan de bouwspeculatie uit den aard zijner positie zonder risico ontvangen, omdat hij meestal geen eigen kapitaal bezit en bij deconfiture dus de nadeelige saldo's op anderen afwentelt. Zijn doel was dan ook niet een huis te bouwen als financieele belegging maar alleen om gedurende den tijd van den bouw te kunnen leven en in het allergunstigste geval bij liquidatie iets over te houden. De personen echter, die bij de bouwspeculatie directe financieele schade lijden, zijn de

leveranciers, de kleine werkbazen en de werklieden, de latsten bij de hier geldende gewoonte meestal echter slechts voor een gering bedrag. De indirecte schade, die uit den revolutiebouw voor den werkman vaortspruit, blijve hier buiten beschouwing".

Er schijnt na het verschijnen van dit rapport nog wel een verbetering te zijn opgetreden in de situatie, o.a. door het instelien van de Dienst Bouw- en Woningtoezicht, maar geheel opgelost werd ze niet en tot 1940 schijnt het aantal deconfitures nog groot geweest te zijn. van der wal wijt deze matschappelijke misstanden aan het systeem van de onbeperkte bedrijfsurijheid.

I I. 2.3

de ontwikkeling van het bouwbedrijf rond 1930

De bedrijfsgrootte was uiteraard mede bepalend voor de matschappelijke status van de bouwbedrijven. In 1930 werd een bedrijfstelling gehouden warvan de cljeers een beeld gaven van de omvang en de soort bedrijuen (*20). 85 \% van alle bedrijven bestond uit $1-5$ personen, 15,28 uit $6-50$ personen en 0,58 uit meer dan 50 personen.

Het bouwbedrijf bleef in de industriele ontwikkeling duidelijk achter: de reden daarvan zocht men in het feit dat het grote a antal kleine en middelgrote bedrijven in de burgerbouw $z i c h$ niet leende voor industrialisatie, de katalysator bij uitstek voor de ontwikkeling van andere 
bedrijfstakken.

De cijfers geven een beeld van de situatie tot eind 1931 .

De krisiaituatie die zich voortslepte tot de tweede

wereldoorlog verhinderde een verder fundamentele wijziging in de situatie.

In de dertiger jaren had de aannemerij het moeilijk. gezien de ekonomigche suatie. De ambachtelijke kwalitelt van het uitvoerend bouwbedeljt en har matschappelijke status nam echter aanzienlijk toe. De mede door de architekten geinitieerde verbetering van de ambachtelijke scholling, door de oprichting van ambachtsscholen, werpt in deze periode har vruchten af.

II. 3

De opdrachtgever

Van de boutheren van de dagen rond 1900 is, althans buiten het juridisch krachtenspel, moeilijk een beeld te krijgen. De overheld als opdrachtgever bestond uit "Waterstaat" een oppermachtig instituut met een verpletterend overwicht in matschappelijk opzicht. De opkomst van de spoorwegen met de bouw van stations en sporwegwerken zorgde voor een sterke opleving in de bouw zij het eenzijdig gericht. "Waterstaatkerken" zijn en waren een begrip. De ontwerpen werden vervaraigo door civiel ingenieurs in dienst van het gouvernement.

Een zeer belangrijke opdrachtgever in architektonische $z$ in was rond 1900 de Rooms-Katholieke kerk. Zeer veel kerken werden in die tijd aan het beeld van steden en dorpen toegevoegd. Deze hausse vond har oorzaak in het zich in toenemende mate manifesteren van het Rooms-Katholieke volksdeel na een periode van achterstelling.

De burgerbouw, dus de particuliere opdrachtgever, stelde aanvankelijk nog niet veel voor, mar ontwikkelt zich vanaf 1870 snel. Soms klaagde men in de vakpers dat het snobisme van de particuliere opdrachtgever de kloof tusisen architektenfantasie en ambachtelijk bouwen onaanvardbaar groot makte. Soms ook is uit de gegevens uit die tijd wel op te maken dat het de principarl in het algemeen toch in de eerste plats te doen was om de laggte bouwsom. Dok toen apeelden besparingen een grote rol. Dat er van opdrachtgeverszijale soms een al te grote druk op de architektembegroting werd uitgeoefend stat wel vast (*21).

Veel juridiache perikelen waren daarvan het gevolg. De architekten zijn daarin, om den brode, niet altijd even karaktervast geweest, de goeden niet te na gesproken. Met andere woorden, zij gaven toe aan de financiele druk ten koste van de kwalitelt van het werk, terwijl zij bij strijdvragen over gebreken als gevolg daarvan, soms tegen beter weten in de zijde van de opdrachtgever kozen. 
II. 4

Samenvatting

Tussen 1850 en 1940 kwam de figuur van de zelfstandige architekt steeds duidelijker naar voren vanuit een wat schimmige situatie, warin enerzijas sprake was van een verstrengeling met het uitvoerend bouwbedrijf en anderzijds van in technische kennis tekortschietende vormgevende kunstenaars.

Een stimulans voor deze ontwkkeling ging uit van de slechte faam van de aannemerij in het begin van de $20 e$ eeuw: er was behoefte aan een terzakekundige onpartijdige vertrouwensman van de opdrachtgever. Die ontstond echter slechts schoorvoetend omdat het matschappelijk wantrouwen aanvankelijk nog groot was vanwege de vroegere bindingen met de aannemerij en vanwege het gebrek aan technische kennis van de ontwerpers van weleer.

Doordat de bonafide beroepsbeoefenaars zich organiseerden in de Matschappij tot Bevordering der Bouwkunst en/of de Bond van Nederlandsche Architecten, kon worden bewerkstelligd dat er een goede beroepsopleiding kwam, die de basis vormde voor matschappelijke acceptatie. Zo groeide geleidelijk naar het jaar 1940 een situatie warin de architekt een algemeen aanvaard en gerespekteerd fenomeen was. Sterker nog: vrijwel alom werd hij beschouwd als de spil van het bouwproces.

Mede dankzij de inspanning van sommige architekten herstelde de annemerij zich van het slechte imago uit het begin van de $19 e$ eeuw, ondanks de negatieve kanten van de spekulatieve revolutiebouw. Als gevolg van de verbeteringen in de scholing voor de onderscheidene bouwberoepen groeide ook hier langzam de matschappelijke wardering voor het uitwoerend bouwbedrijf. Hieraan hebben de architekten het hunne bijgedragen. Vooral in de latste tien jaren voor de tweede wereldoorlog blijkt veel matschappelijk vooroordeel. te zijn overwonnen. 
1. Prof. E.H. Gugel

$2 \mathrm{mr}$. W. de Vries Wan

3 J.P. Bruynzeel

4 Bouwkundig Weekblad

5 WVHR

6 Dan. J. Sanchez

7 F. R. Voge1 - Hannover

8 Bouwkundig Weekblad

9 Bouwkundig Weekblad

10 Bouwkundige Bijaragen

11 Albert Louvet
- ontwierp o.a.

- gebouw K en W 1875

- Sociéteit Minerva Leiden 1876

- Universiteitsgebouw Utrecht 1894

- torenspits jieuwe Kerk Delft 1873

- Bulletin KNOB/jrg 1980 afl.3

- De rechtspositie van de architekt, diss. Leiden 1900

- 1900 blz. 398

- 13-5-1891

- "de Betrekking van Architect" lezing voor - A et A, 17-2-1864

- De wettelijke bescherming van het architectenberoep in Amerika, Bouwkundig Weekblad $1911 \mathrm{nr} .49$

- no. 14 - 05-4-1930

- no. $15-11-4-1930$

- 1868

- L'art de 1"architecture et la profession de 1'architecte Librairie de la Construction Moderne - Paris (ongedateerd)

$12 \mathrm{Jacob}$. Klinkhamer b.i. - Gedenkschrift van de Kon. Akademie Polytechnische school te Delft $1842-1905$

13. J.H.A. Mialaret

14 Bouwkundig weekblad

15 Dr M.P. van der Linden

16 Bouwkundige Bijdragen

17 ir. J.J. van der Wal

18 prof. G. E. Engberts

19 ir. J.J. van der Wal

20 ir. J.J. van der Wal

21 De opmerker
- De "Opmerker" 02-02-1907

- nr. 21 23-5-1925 blz. 302

- De BNA en haar fusie met de Maatschappij tot Bevordering der Bouwkunst Bouwkundig Weekblad 1958 n.r. 20

- 1863 pag. 111 e.v.

- De Ekonomische Ontwikkeling van het Bauwbedrijf in Nederland

Waltman, Delft 1940, blz. 41 e.v.

- De Nederlandse en Amsterdamse Bouwaktiviteiten $1850-1914$ diss. Kluwer 1977

- De Economische ontwikkeling van het Bouwbedrijf in Nederland

waltman, Delft 1940, blz. $44 \mathrm{e} . \mathrm{v}$.

- idem, blz. 52 e.v.

- 1890 blz. 402 e.v. 
ONTWIRKELINGEN VAN DE RECHTSPOSITIE VAN DE ARCHTTEKT TEN OPZICETE VAN AANNEMER EN OPDRACHTGEVER TUSSEN 1850 EN 1940

\section{III.1 Inleiding}

III.2 De rechtsverhouding architekt - principaal III.2.1 de ontwikkeling van de kontraktuele relatie

III.2.1.I het rechtskarakter van de opdracht III.2.1.2 de vertegenwoordigingsbevoegdheid van de architekt

III.3 De buitenkontraktuele rechtspositie van de architekt

III.3.1 de architekt en de onrechtmatige daad III.3.2 het auteursrecht m.b.t. de bouwkunst III.3.3 titel-en beroepsbescherming

III.4 De rechtspositie van de annemer en zijn relatie tot de architekt
I I I. 4.1
inleiding
III.4.2 de rechtsongelijkheid van opdrachtgever
III.4.3 architekten stellen de misstanden aan de kaak
III.4.4 de rechtsverhouding opdrachtgever -
III.4.5 de Raad van Arbitrage ingesteld
III.4.6 nieuwe bedreiging voor de annemer; hulp aan derden
III.4.7 de besteksbepalingen van de architekt en het boetebeding rond 1900
III.4.8 de koncept-AAV 1911 van architekten, ingenieurs en aannemers

III.5 De aannemer als opdrachtgever van de architekt.

III. 6 Samenvatting

III.7 Notenlijst 
ONTWIKKELINGEN VAN DE RECHTSPOSITIE VAN DE ARCHITEKT TEN OPZICHTE VAN AANEMER EN OPDRACHTGEVER TUSSEN 1850 EN 1940

III. 1

Inleiding

Hoewel in het bouwproces steedis sprake is van de hierboven genoemde partijen $1 \mathrm{~s}$ er toch geen sprake van een driepartijen-kontrakt. De onderlinge rechtspositie bestat uit een samenstel yan wederzijjdse overeenkomsten van geheel verschillende aard zoals wij in hoofdstuk I hebben gezien. Los echter van de kwalifikatie var deze verbintenissen in juridische zin (verrichten van diensten, aanneming van werk) bestat de rechtsverhouding architekt-principaal in de tijd gezien uit twee afzonderlijke delen, dit zijn ontwerp en bouwvoorbereiding tot de aanbesteding en daarna bij de uitvoering, vertegenwoordiging van de principal (aanbesteder) in diens kontraktuele verhouding tot de aannemer. Het is overigens niet zo dat "de" opdracht a an de architekt per definitie beide onderdelen van de oveceenkomst, dus van ontwerp tot en met de uitvoering, beslaat. Het was vroeger niet ongebruikelijk om voor deze onderscheiden fasen twee afzonderlijke architekten in te schakelen. Deze splitsing sproot voort uit het feit dat de ambachtelijke bekwamheid, nodig voor het uitoefenen van toezicht op, ook niet altijd zeer bedreven aannemers, de meeste gerenommeerde architekten/ontwerpers rond 1900 veelal ontbrak (zie hoofdstuk II.2). Juist in die uitvoerende fase heeft de rechtspositie van de architekt het meest ter diskussie gestaan.

De uitvoerende architekt trad, als de opdracht zich daarover uitstrekte, als juridische vertegenwoordiger op in de overeenkomst tussen aanbesteder en aannemer zoals deze bij de gunning ontstaat. Het ontbreken van deskundigheid bij de principaal-aanbesteder verschafte de architekt bij de begelelding van de uitvoering een komfortabele positie ten opzichte van de aannemer war het om bouwtechnische zaken ging (zie hoofdstuk I.3.3). Zoals wij zullen zien is de rechtspositie van de a annemer ten opzichte van de principaal sinds 1850 geëvolueerd, van volstrekt ondergeschikt tot een systeem warbij de rechten van de aannemer beter dan voorheen zijn gewaarborgd, al heeft dat ontwikkelingsproces wel een kleine honderd jaar gevergd.

Niet in alle gevallen is de vertegenwoordigende positie van de architekt zo benijdenswardig geweest. vooral bij de erkenning door ambesteder van door de architekt goedgekeurd meerwerk en aanvaarde termijnen ontstaan veelvuldig problemen door onbegrip of neiging tot chicanes. 
III. 2

De rechtsverhouding architekt-principal

III. 2.1

de ontwikkeling van de kontraktuele celatie

De behoefte an regelen die de rechtsverhouding architektprincipal bepalen kont eerst rond de jaren 1920 tot een afgerond geheel. Dit nadat reeds in 1884 "de honorar um quaestie" in de vakpers aanleiding was voor een a antal publikaties over gelijkluidende regelingen in Engeland (* 1). Zweden en Duitsland. Door het ontbreken van eigen regels werden deze regelingen vak overgenomen door de gekwalificeerde architekten. $Z i j$ kwamen in grote lijnen met elkaar overeen. De engelse regels luidden aldus:

bouwsom tot f. 1200,-- 158 van de bouwkosten bouwsom van f. $1200,-$ tot $f 6000,-10 \%$ van de bouwkosten bouwsom boven $f$. $6000,-\quad 5 \%$ van de bouwkosten (bouwkosten zijn loon + materialen)

Verrekend werden op basis van bestede tijd: alle nevenwerkzamheden zoals bemoeienisen met kunstwerken, meubelen, decoraties enzowoorts. Ook tercinaankopen, onderzoek naar servituten, schaderegelingen in het kader van het burenrecht, wijzigingen in de bouw en wijzigingen in het door de principal goedgekeurde ontwerp.

Tegenover het honorarium stond als verplichting het leveren of verrichten van:

a schetsontwerpen:

b een volledig plan met beschrijving, zodanig dat een aamnemingskontrakt kon worden gesloten, en het maken van de begroting;

c alle detailtekeningen:

d het houden van toezicht op de bouw;

e het kontroleren van de rekeningen (excl. bijwerk).

Albert Louvet gaat in zijn befaamde oeuvre "I"Art de 1 "Architecture et la profession d"Architecte" (*2) diepgaand in op alle facetten het vak in Frankrijk voor 1900 betreffende. Naast de vermelding van de toen gangbare franse regelen komt hij tot een nauwkeurige specifikatile van de architektentaak (Iivre I, pag. 93 e.v.), warblj zelfs de te hanteren schal voor de te produceren tekeningen stat aangegeven.

Het ontbreken van algemeen a anvarde regelen voor de honorering van de architektenprestatie leverde veel

architekten rond de eeuwisseling over an de willekeur van de opdrachtgever met name war het het tijdstip van betalen voor zijn diensten betrof.

Op 8 juli 1884 riep het Amsterdamse Hof en groot aantal vakbeoefenaren als getuigen op teneinde ingelicht te worden "of het bij aanbestedingen die onder toezicht van eenen architect worden voorbereid en uitgevoerd, steeds 
gebruikelijk is, tenzij het tegendeel bedongen zij, den architect een termijn van zijn loon te betalen lindien hij dit verlangt) zoo dikwills ex een termijn van de aanneemsom is verschuldigd, en zulks in gelijke verhoudingen" (* 3 ). Blifkeng het kommentaar van Bouwkundig weekblad-redaktielid Weissman tornde de kriaissituatie ook an de eensgezindheid van de architekten ondat "velen behalve door laag tarief, ook door groote betalingsfaciliteiten klanten trachten te lokken, en daarom nimmer van betaling in termijnen spreken". Zijn pleidool voor uniforme regelingen voor bonafide architekten ("met de beunhazen is toch nooit iets te beginnen" - aldus welsgman) in het kader van normstelling van de opdrachthonorering en wijze van betaling, wordt door architekt en ere-voorzitter van het genootschap J.H. Leliman opgepakt met een spreekbeurt op de matrse jaarvergadering 1884 over "Ons vak, ons 1 oon, ons $\operatorname{lot}^{\prime \prime}(* 4)$.

Het is goed om hier even nader bij stil te staan. Naast een zeer lezenswardige inleiding over de negatieve kanten van de verhouding publiek-architekt konkludeert hij dat er in de honorariumpositie van architekten sinds 50 jaar niets is veranderd. Toen bepalde namelijk de Raad voor de Burgerlijke Gebouwen het honorarium op de $12 \mathrm{e}$ pluviose van het jaar VIII op 5 van de bouwkosten, samengesteld uit:

- $0,5 \%$ voor "plans en bestek"

- 1,5 voor "surveillance"

- 2 voor de regeling van de eindafrekening.

Hij wees erop dat deze franse standaard uit de tijd van de totstandkoming van de code Civil, welke op 10 oktober 1841 bij ministerieel decreet werd bevestigd, als onbillijk werd ervaren gezien de veranderingen van tijd, van landsaard en gewoonten. Samenvattend:

- omdat de bouwmeesters meer en beter praduceren

- omdat zij meer onkosten hebben mede vanwege een groter aantal hoger gesalarieerden;

- omdat zij van hoger matschappelijk niveau zijn dan aannemers, werkbazen en werklieden:

- omdat er een diakrepantie is tussen de stationnaire beloning en hogere onkasten:

- omdat voor hen "versieten toestanden geen warde en gezag nebben".

Hoewel de genoemde argumenten niet alle steekhoudend en geen van alle onderbouwd zijn, is er niet veel fantasie voor nodig om te erkennen dat $5 \%$ voor kleinere en arbeldsintensieve werken (restauraties), het leeuwendeel van de opdracht in die tijd, een te magere honorering was.

Hij stelde vier stelsels van betallng voor:

a per uur arbeid

Hij stelde voor een honorarium (dus zonder toezicht, reis-, 
bureau- en tekenkosten, en administratiekosten) dat per uur varieerde van $f .2,50$ voor werken minder dan f. 1.000,- tot f. 8,- voor werken van meer dan f. $20.000,-$. De helft te voldoen na voltooiling van het ontwerp, de andere helft bij oplevering. Overigens was die standaard in Frankrijk zelf, door de société Académique d'Architecture de Lyon bij besluit van 3 juni 1880, al aangepast nar 10 voor zeer arbeidsintensieve onderdelen van dekoratieve aard, meubelen, herstellingen en veranderingen. voorts een verdere differentiatie voor niet uitgevoerd werk, reis-en verblijfkosten, opnemingen enzovoorts (*5).

b per $\mathrm{m} 2$ of $\mathrm{m} 3$ verwerkt materiaal

Deze wijze had niet zijn sympathie, en derhalve ging hijer verder niet op in. Hij verwees naar het rapport Rose, Metzelaar, Gosschalk van 1867 voor de motivering.

c per honderd gulden bouwkosten

Deze beloningswijze had verre zijn voorkeur, zij het op andere leest geschoeid dan "den Napoleontischen standaard, vooral voor dezulken, die uitsluitend van hun bouwmeesterschap moeten leven, en geen bij-emolumenten hebben, of geen percenten van geleverae bouwmaterialen genieten"

Zijn voorstel:

- 10\% over de begrote bouwsom inkl. meerwerk

\begin{tabular}{|c|c|c|c|c|c|c|c|}
\hline 85 & $\begin{array}{l}\text { voor } \\
\text { voor }\end{array}$ & $\begin{array}{l}\text { bouwsommen } \\
\text { bouws sommen }\end{array}$ & $\begin{array}{l}\text { tot } \\
\operatorname{van}\end{array}$ & f. & $\begin{array}{l}10.000 \\
10.000\end{array}$ & tot & 20.000 \\
\hline $6 \%$ & voor & bouwsommen & van & $\mathbf{f}$ & 20.000 & tot & E. 100.000 \\
\hline 58 & voor & bouwsommen & boven & f. & 100.000 & & \\
\hline
\end{tabular}

(alles zonder "onkosten")

Hij deed de suggestie om de helft van het honorarium te voldoen na levering van ontwerp met bestek en begroting, doch zonder details. Maandelijkse onkostenverrekening.

Voorts bepleitte Leliman, een geregeld kontrakt voor de voorwarden "te stellen" door beide partijen en een vaste formulering als standaard voor architektendeklaraties.

Een parallel voor betaling van het honorarium met de aannemersdeklaraties achtte hij ongewent vanwege "de zee van onarngenamheden" die daar het gevolg van is.

Hij pleitte voor een benoeming van een speciale kommisile door de Maatschappif tot Bevordering der Bouwkunst en Arti \& Amicitia om de honorariumkwestie te bestuderen en zijn voorstellen te overwegen.

Leliman kaartte de problematiek aan in 1884. Eerst in 1888 werd in de Algemene Vergadering van de Matschappij tot 
Bevordering der Boukunst ( 31 mei 18B8) de eerste zogenaande "tabel vasgelegd met de relatie bouwkosten en honorarium. Dat was voorlopig het enige, late, succes.

In 1903 zag het hoofabestuur van de Matachappij aanleiding tot het benoemen van een kommissie ter bestudering van het honoreringsvraagstuk ("de tabel"). De bemanning bestond uit louter vakgenoten te weten: Cuypers (Ed), Cuypers (Jos.Th.J.), Freen, Huurman, Mutters en verheul Dzn. (* 6). In het door de kommistie gedane voorstel stond eenvoud voorop. Het luidde:

- invoering van arie klassen

I gewone bouwwerken (ook verbouwingen)

II monumentale gebouwen

II bijzondere opdrachten als dekoratieve werken, gedenktekenen en stoffering;

- invoering van een apart honorarium bestanddeel "begroting" (na het bestek) omdat hierover veel geschillen waren gerezen bij afrekening na het ontwerp:

- "detailtekeningen" te wijzigen in "algemene details:

- "toezicht" te wijzigen in "hoofaleiding" am verwarring met het dagelijks toezicht uit te sluiten;

- verdeling van het totaalhonorarium naar gelang de onderdelen van de opdracht; hiermee werden de steeds terugkerende geachillen over het tijdstip van betalen voorkomen;

- een betalingsregeling voor de betaling van het honorariumdeel "hoofdleiding en uitvoering" bij de uitvoering bestaande uit $50 \%$ bij de anvang, $40 \%$ bij de le oplevering en 108 na de onderhoudstermijn:

- een differentiatie van het uurloon van de architekt voor kleine werkzaamheden ad hoc.

voorts werd tot een bijstelling van de "toelichting" a anbevolen, een summiere artikelsgewijze toevoeging van de tabel, zodat de rechtspositie van de architekt duidelijker werd gedefinieerd:

art. 1 - definitie honorarium

art. 2 - definitie wederpartij

art. 3 - honorariumstaffeling bij werken in uitvoering

art. 4 - wijzigingen ná het goedgekeurde ontwerp

art. 5 - klasseregeling voor opdrachten uit meerdere komponenten samengesteld

art. 6 - toerekening van meerwerk en de kosten van installaties an de bouwsom (100\%)

art. 7 - betalingstermijn - verplichting voor de opdrachtgever bij niet-uitgevoerd werk (binnen 6 maanden) voor geleverde prestatie

art. 8 - regeling bij overlijden van de architekt

art. 9 - eigendomsrechten op tekeningen van de architekt 
art. 10 - geschillenregeling - deze was erg eenvoudig: "door elk der partijen zal een arbiter worden benoemd welke beide een derde benoemen.

partijen zullen zich volgens de uitsprak van arbiters gedragen ${ }^{\text {th }}$.

In feite werd met dit advies de grondslag gelegd voor wat later Algemene Regelen zou gaan heten. Een grote stap voorwarts in de rechtsbescherming van de architekt.

Het voorstel werd voor kommentaar voorgelegd aan de leden van de Matschappij. De reakties waren niet veelomvattend (* 7). Curieus in verband met de huidige aktualiteit is het voorstel van ene W.C. van Goor over de bepaling van de bouwsom door middel van een middeling van de inschriffbedragen. Een suggestie die niet is gevolgd, warschijniljk om dezelfde redenen als warom gelijke voorstellen anno 1984 terzijde zijn gelegd, namelijk het probleem van het elimineren van extreem hoge en extreem lage inschrijfbedragen.

In de definitieve versie van het voorstel van de Commisie d.d. 18 mei 1904 (* B) is de geschilienregeling aanzienlijk uitgebreid. Zij ziet er, kort samengevat als volgt ult: art. 9 - uitsluiting gewone rechter; verwijzing naar de permanente Commissie (PC)

art. 10 - samenstelling PC - arie personen benoemd door het Hoofdbestuur van de Matschappij. Zetelvestiging. art. 11 - kostenregeling voor partijen voor wat betreft de PC bij oplassing of verwijzing van het geschil

art. 12 - vormaanwijzing voor de $\mathrm{PC}$

art. 13 - doorverwijzing naar "Commissie van Advies" (CVA) art. 14 - samenstelijng CVA - 3 leden, éćn van elke partij, derde in overleg; bij gebrek aan overeenstemming mogelijkheid tot inroepen van de kantonrechter

art. 15 - vorm- en procedurevoorschriften

art. 16 - uitspraaktermijn - rechtskracht

art. 17 - ontheffing wettelijke vorm voocschriften: vertegenwoordiging van partijen.

De invloed van de gewone rechter bleef krachtens de overeenkomst beperkt tot zijn tussenkomst bij het benoemen van de derde partij in de CVA.

Het is opmerkelijk dat in de PC per definitie geen rechtskundige zitting heeft, en dat dat ook in de CVA niet vereist was. Tegen de énzijdige bemanning van de $P$ C rees ook in vakkringen verzet, met name van de architekten Weissmann en Leliman, zonder resultaat overigens (*9).

Met enige triomf werd in de vakpers van 1908 een vonnis van de Rechtbank Den Haag (niet gepubliceerd) gereleveerd warbij op grond van "de tabel" van de Maatschappij in het voordeel van de eisende architekt werd beslist. Dat partijen toch bij de rechter terechtkwamen ondanks artikel 9 van de toelichting doet vermoeden dat de binding van 
partijen aan het arbitral beding hiervan toch te wensen overliet, of liever, door somigen niet werd geaccepteera.

Hoewel wan de totstandkoming ran regels stellig en positieve werking uitging, waren de misstanden nog bijlange na de wereld niet uilt. Zulks blijkt uit een redaktioneel artikel in Bowwkindig Weekblad $1910 \mathrm{nr}$. 1 blz. 3 waarin verzucht wordt dat de architekten zelf schuld hebben aan het ontstaan van geschililen door het werken onder de markt" van kollega's. Daarmee werd de binding van de regeling ontkracht. Men benadrukte nogmals de noodzaak tot het sulten van een schriftelijke overeenkomst tussen bouwheer en archiltekt.

Een redaktioneel artikel in het Bouwkundig Weekblad 1913 (* 10) van de hand van "mr. G"(oseling) gaat uitvoerig in op de eenheid van de Tabel en de Toelichtingen. Zoals ook thans nog gebeurt werden deze door somigen apart gehanteerd, daarmee een bron van geschillen vormend. 0ok rechtscollege bleken die ondeelbaarheid niet altijd te aanvarden. De Rechtbank te Harlem besliste (* 11) dat war partijen slechts de tabel waren overeengekomen en niet uitarukkelijk de daarbij behorende toelichting, er niet van mocht worden uitgegaan dat de geschillenregeling, die in de toelichting was opgenomen, wan kracht was en dus de gewone rechter mocht worden gepasseerd. In hoger beroep bevestigde het Hof te Amsterdam deze uitspraak. Blijkbaar was onduidelijk wat partijen precies waren overeengekomen, ofwel er bestond twijfel bij de opdrachtgever inzake de onpartijdigheid van de PC. Het betreft hier waarschijnlijk toch een incidenteel geval warbij de rechter zich bepalde tot het al dan niet duidelijk overeengekomene. Evenwel had een eerder arrest het Hof te Amsterdam het gebruik van de Tabel-sec op grond van "bestendig gebruik" gesanctionneerd. Het beroep van Mr. Goseling op de vermeende inconsistentie van thet Hof lijkt echter misplaatst. Weliswar voert hij aan dat art. 1383 BW en art. 1384 BW bepalen dat alle bedingen in een overeenkomst gemakt in "derzelver verband" moeten worden genomen, maar toont daarbij niet aan dat de binding hieran de bedoeling van partijen was of niet, en evenmin dat de bestendigheid van het gebruikelijk beding dan wel an verweerster bekend moet zijn geweest.

Mr. Goseling stelt darop enige wijzigingen voor in de roeldchting, namelijk uitbreiding van de titel met een verwijzing natr de geschillenregeling en opneming van een art. 20 warin de ondeelbaarheid wordt bevestigd warmee de kans op exceptief verweer zou worden verkleind.

Architekt C.N. van Goor merkte in zijn kommentaar op de nieuwe voorgtellen van de Commissie voor de honorariumregeling ca. 1915 op, (*12) dat de architekten verzuimen hun verplichtingen te formuleren tegenover de rechten die zij vorderen. Hij deed daarvoor een voorstel warbij de 
goede trouw van de architekt central stond bij het koncipiëren van het projekt, samen met de doelsteling en het erbij behorende budget. Hij deed voorts de suggestie om de opdrachtgever te ontheffen van zijn (morele) plicht om projekten ook uit te voeren met de aanvankelijk

geëngageerde architekt, zij het dat wel honorering voor bewezen diensten aiende plaats te vinden. Hij keerde zich tegen het opnemen van de kosten van werktekeningen onder de bouwsom. wanwege de inkonsekwentie ten opzichte van de opzichterssalariëring.

Deze bemerking doet heel merkwaardig aan. Immers, zoals Van Goor ook konstateerde, berekende de architekt in dat geval over de tekenlonen ook nog eens zijn honorariumpercentage. De tekenaars zouden daarmee in feite behoren tot het aangenomen werk. Wellicht komt dit voort uit het feit dat de aannemer was belast met het maken van de uitvoeringstekeningen?

Als verrekenmogelijkheid geet hij aan:

- het aannemen van tekenaars per werk, de salarissen direkt te betalen door de opdrachtgever:

- het overeenkomen van een prix fixe voor dit onderdeel van het werk.

De werktekeningen werden in die tijd inderdaad veelal op het werk vervaardigd.

Voorts merkte Van Goor op dat bij de geschillenregeling de opdrachtgever geen invloed had op de samenstelling van het scheidsgerecht en dat daarmee de schijn van "eigen gerechtigheid" werd gewekt. Hij pleitte voor een mogelijke gang naar de rechter, mits tevoren overeengekomen.

Een dergelijke suggestie kan slechts zijn voortgekomen uit het streven om een eventuele veronderstelde partijidigheid bij arbitrage bij voorbat uit te sluiten.

In 1919 werd de aanvankelijke "Toelichting" door toedoen van de BNA-Comissie, warin zitting hadden: Dwars, Van Goor, Van Creveld (jurist), Cuypers en Rosenboom (jurist), veranderd in een kompleet le koncept-voorstel voor de Algemene Regelen (* 13). Dit bevat:

art. I - definitie architekt

art. 2 - definitie opdrachtgever

art. 3 - totstandkoming opdracht (niet schriftelijk)

art. 4 - wederzijdse verplichtingen, koppelen van regelen en tabel.

art. 5 - inhoud van de opdracht, voorlopig ontwerp, globale kosten, omschrijuing van norm

art. 6 - varianten verrekening

art. 7 - definitief ontwerp

art. 8 - varianten definitief ontwerp

art. 9 - vereisten van het ontwerp

ate. 10 - recht op honorarium bij overschrijaing bouwsom

art. 11 - besteding

art. 12 - verrekening van bestedingskasten, onderzoek servituten enzovoorts

art. 13 - uitvoering, omschrijving werkzaambeden

art. 14-dienstbetrekking toezicht, verrekening 
kosten en kosten werktekeningen (verrekenbaar)

art. 15 - eigendomsrecht tekeningen

art. 16 - auteursrecht architekt in relatie met Auteurswet 1912

art. 17 - verbod tot hergebruik ontwerp door architekt

art. 18 - bevoegdheid architekt tot wijzigen van het bestek

art. 19 - definitie "bijwerk" en "bijgekomen werk"

art. 20 - beperking bevoegdheid van de architekt tot de opdracht van bijwerk. (post onvoorzien of 1 van de bouwsom)

art. 21 - voor "bijgekomen" werk goedkeuring van de opdrachtgever vereist

art* 22 - ansprakelijkheid van de architekt jegens aannemer bij overschrijden bevoegdheid ex art. 20 en 21

art. 23 - exklusief recht van de architekt tot het beoordelen van de aannemersprestatie

art. 24 - verwijzing naar tabel, ondeelbarkeid tabel en regelen, uitsluiting esthetische warde

art. 25 - idem

art. 26 - samenstelling bouwsom; installaties: géén adviseurs $100 \%$ toerekenbaar, anders $50 \%$

art. 27 - klassering komplexe opdrachten

art. 28 - toeslag verbouwingen

art. 29 - uurtarieven

art. 30 - 308 verhoging bij engageren van 2 architekten

art. 31 - honorariumverdeling: 458 bij gunning, verder overeenkomstig aannemersterfijnen; laatste 5 na onderhoudstermijn; verschottenregeling

art. 32 - verrekening voortijdig geëindigde opdracht

art. 33 - herroepen opdracht door de opdrachtgever

art. 34 - vererven rechten/verplichtingen opdrachtgever architekt

art. 35 - beëindiging opdracht door architekt

art. 36 - overlijden architekt

art. 37 - aansprakelijkheid architekt met betrekking tot fouten in het ontwerp

art. 38 - beperking aansprakelijkheid architekt naar de aard van de opdracht

art. 39 - idem ten anzien van personeelstouten

art. 40 - aansprakelijkheid van de architekt bij uitvoering en ontwerp

art. 41 - aansprakelijkheid van de architekt bij ontwerp-opdracht

art. 42 - aansprakelijkheid van de architekt bij uitvoeringsopdracht

(van belang is hierbij de scheidingsmogelijkheid tussen ontwerp en uitvoering. Waarschijnlijk liggen hieraan de verschillende juridische kwalificaties ten grondslag)

art. 43 - bepaling schadevergoeding

art. 44 - aansprakelijkheid van de architekt voor vertragingsschade

art. 45 - aansprakelijkheid van de architekt met betrekking tot publiekrechtelijke bepalingen 
art. 46 - aansprakelijkheid van de architekt voor adviezen advil seurs

art. 47 - a ansprakelijkheid van de architekt voor gegevensverstrekking aan adviseurs

art. 48 - duur van de aansprakelijkheid ( 3 jat na eindoplevering)

art. 49 - geschilienregeling; uitsluiting gewone rechter: scheidsgerecht (é̉n of $1+1=3$ ) uit de zogenamde "Commissie van Geschillen (CVG), ingesteld door de Matschappij; het derde lid van het scheidsgerecht werd benoemd door de voorzitter van CVG: termijnstelling benoeming scheldsman tegenpartij, benoeming door voorzitter CWG

art. 50 - verkiezing van de 12 leden van de cVG

art. 51 - voorschotstorting partijen

art. 52 - procedureregels bij geschil

art. 53 - vertegenwoordiging van partijen

art. 54 - kwalifikatie uitspraak

art. 55 - status van de uitsprak, uitspraaktermijn

Het definitieve voorstel (* 14) van het BNA-Bestuur werd op de Algemene Vergadering van 8 juli 1922 aangenomen en bevatte in hoofdzaak de elementen welke in vorige voorstelien waren vervat, $t . w$. hoofdstukken:
1 - algemene bepalingen
2 - omvang opdracht
3 - eisen architekt bij uitvoering
4 - aansprakelijkheid architekt
5 - bevoegaheden architekt
6 - verplichtingen opdrachtgever honorariumtabel
7 - beëindiging opdracht
8 - eigendoms- en auteursrecht
9 - geschillen

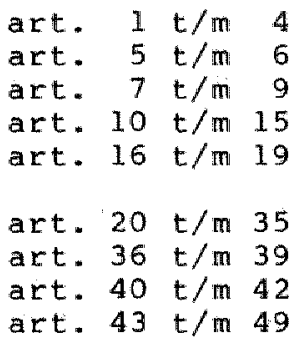

De geschillenregeling is conform het eerdere voorstel van 1919.

Met de vaststelling van de AR 1922 was een onderbouwing verkregen van de cechtspositie van de architekt in het bouwproces. Uiteraard was deze niet volkomen, mar afgezien daarvan viel er ook over de randvoorwarden nog genoeg te strijden. Zo ontstond er in 1923 een vinnige digkusgie tussen het BNA-Bestur en de toenmalige Minister van Arbeld, Handel en Nijverheid over de verrekening van reiskosten van de architekt en over het toekennen war een duurtetoeslag op de tabellen van de AR-woningbouw van 25 fo ter kompensatie van de gestegen kosten sinds de vaststeling in 1916 .

Na 1922 is er in de vakliteratuur weinig meer over de $A R$ te vinden. De regeling was kennelijk grondig en voldeed goed.

Dat de aanvarding van de AR in 1927, toch klaarblijkeljjk nog geen gemeengoed was, blijkt uit de triomfantelijke 
melaing in het Bowkundig weekblad van dat jaar dat het Hof Amsterdan op 19-01-1927 een uitspraak van de Rechtbank Amsterdam had ontkracht. Dit geschiedde door de eis te honoceren van een architekt die in zijn honorarium werd te kort gedaan als gevolg van het feit dat verweerster in eerste aanleg voor een voorlopig ontwerp geen honorarium verschuldigd zou zijn. Deze procedure leverde twee belangrijke zaken op namelijk:

1 de exkenning van recht op loon na gegeven opdracht

2 de erkenning van "de" honorariumregeling, ook al was deze bij de opdrachtaanvaarding niet overhandigd.

Dat was in 1927 nog wel voorgeschreven. Het Hof oordeelde echtec dat strafsancties d.m.v. het niet-betalen wan het honorarium niet voortvloeiden uit de AR 1922 .

Het duurt tot 1938 voordat opnieuw officielle kritiek opduikt op de AR voor wat betreft de geschillenregeling. Mr. Hartzfeld (* 1.5) stelt het scheidsgerecht an de orde zoals dat door de BNA is ingesteld krachtens het Reglement en de $A R$ 1932. Alle geschilien worden beslecht door een college bestaande uit twee architekten en éćn nietarchitekt, die zich door een architekt kan laten vervangen, wardoor geen gelijkwaardige vertegenwoordiger van de opdrachtgever gegarandeerd is. Bovendien is de, vaste, jurist-secretaris ook advokaat wardoor belangenverstrengeling kan plaats inden. Riep de opdrachtgever onbevoegaheid van de scheidslieden in dan moest hij hierover nog eens procederen woor de gewone rechter. Hartzfeld ried de opdrachtgevers aan om bij het verstrekken van de opdracht aan de architekt, de bevoegdheid van het scheidsgerecht uitarukkelijk uit te sluiten.

Het BNA-Bestuur stelde hier tegenover dat er geen goede opdrachtgeversvertegenwoordigers te vinden zouden zijn die verstand van deze zaken hadden. Voorts dat de voorzitter van het college, niet-architekt, als een hoogstaand man kan worden beschouwd en voldoende warborg is voor onpartijaigheid, dat weliswar de jurist-secretaris praktiserend advokat was en ook wel voor architekten optrad, mar noolt in eén zaak in beide kwaliteiten. Op het briefpapier van de architekt diende voorts een verwijzing nar de AR te staan. Was dat niet het geval, dan stond de gang naar de gewone rechter ten allen tijde open, aldus het Besture. 
III.2.I.I

het rechtskarakter wan de opdracht

In het inleidende hoofdstuk $I$ is onder $I .3 .2$ ingegaan op het rechtskarakter van de ontwerp-opdracht. De opdracht tot direktievoeren neemt echter ten opzichte hiervan een aparte plats in. Hier speelt méer nog dan in de ontwerp-opdracht de vertegenwordigingsbevoegdheid een rol. $\mathrm{Na}$ de hen al dan niet verleende ontwerp-opdracht kon de architekt de leiding van de uitvoering worden opgedragen. Daarmee werd hij "derde" of liever gezegd mede-partij in de overeenkomst a anbesteder-aannemer door verkregen vertegenwoordigingsbevoegdheid. Géén omstandigheid heeft meer aanleiding gegeven tot een eindeloze stroom procedures dan deze positie, die juridisch niet duidelijk geformuleerd was. 2 ijn bevoegdheid tot het vertegenwoordigen van de a anbesteder was immers in het geding.

Reeds in 1897 wijdt mr. J. Limburg (* 16) een uitvoerig betoog aan de rechtspositionele aspekten bij uitwoering van het werk en direktievoering. Hij komt tot de kwalifikatie "huur van diensten" (met een verontschuldiging!) amdat slechts kwantitatieve arbeid in het geding is. Eerder kwam Van Lennep (*17) tot lastgeving.

Hij schrijft dat de diskussie bouwmeester-architekt of aannemer nog volop aan de gang is, met verwijzing naar van Lennep's proefschrift ten aanzien van 1645 BW, warbij hij bovendien aantekende dat art. 1185 1id $B$ BW wél

"metselaars, timmerlieden en andere werkbazen" als prefecente schuldeisers erkent, mar dat architekten in die opsomming ontbreken, volgens zijn visie als gevolg van de personele unie architekt/aannemer anno 1838 , het jaar warin het Burgerlijk Wetboek van kracht werd. Hij attendeerde voorts op een lacune in 1647 BW terzake van opzegging door de aanbesteder. Het artikel noemt namelijk met name de "aannemer", niet de "bouwmeester" van $1645 \mathrm{BW}$. Dat zou betekenen dat het specifiek aspekt van de aanneming, namelijk de éénzijdige opzeggingsmogelijkheid van de anbesteder niet voor de architekt zou gelden: de architekt zou bij opzegging door de opdrachtgever deze dus alleen kunnen dagvaarden tot schadevergoeding. Echter: wanneer de overeenkomst als huur van diensten zou worden gekwalificeerd zou ontbinding met schadevergoeding mogelijk zijn. Een terugkeer naar de oude toestand houdt dan terugkeer naar de situatie van vóor de totstandkoming van de overkomst in, terwijl de architekt zijn tekeningen en plannen bovendien kan terugeisen.

Hendrix (* 18) rangschikt de vertegenwoordigingsbevoegdheid resoluut onder de lastgeving (1829-1856 BW). Hij verwijot naar het arrest Hof Den Haag 26-11-1915 NJ 1916/744. Het ging hierbij om de vraag of de overeenkomst behalve als ontwerp-opdracht, ook voor direktievoering door de principaal éénzijaig kon worden beëindigd, zoals bij lastgeving is toegestaan (1851 BW). Het Hof konkludeerde 
inderdaad in die zin, als ook Rb Den Haag 28-12-1914 WJ $1915 / 1197$, als ook art. 35 van de toenmalige Algemene Regelen 1913, overeenkomend met het huidige art. 40 id 1 AR 1971 .

Dr. M.A.M. Cremers (* 19) rangschikt de bouwleiding eveneens onder "lastgeving". Hij meldt echter ook afwijkende beolisingen ( 20 ). Hij voert ten a anzien van dit labtste tegen andersdenkenden an dat zij de tweeledigheld van de rechtsverhouding uit het oog verliezen, van lastgeving is pas sprake nă opdrachtaanvarding voor wat betreft de uitvoering. Cremers" kenschets (1926) van de col van de architekt bij de uitvoering is er één van leidinggevende aard, dug aktief, en niet passief als toezichthouder. Hij grondt dit op het feit dat wijzigingen en nadere detaillering tijdens de uitvoering onvermijdelijk zouden zijn.

cremers ging ver in zijn verdediging van de autonomie van de architekt in het uitvoerend bouwproces ten aanzien van de goedkeuring van meer-en minderwerk. Tezamen met het afgeven van betalingscertifikaten en goedkeuring van het werk was die autonome positie een bron van wrijuing en processen, warop hierna nog wordt teruggekomen.

Cremers baseerde zich daarbij hoofdzakelijk op het ontbreken van kennis bij de principal, op artikel 1375 warin wordt gesteld dat overeenkomsten niet slechts verbinden tot hetgeen uitdrukkelijk bepaald is, maar ook tot datgene wat door billijkheid, het gebruik en de wet wordt gevorderd en art. 1379 BW waarbij is bepaald, dat bij tweeërlei uj.tleg van de bewoordingen van een overeenkomst de bedoeling van partijen doorslaggevend is. Dat goedkeuring van meer- en minderwerk en het goedkeuren van het werk mede de bedoeling van partijen zou zijn lijkt boud gekonkludeerd, al lijken enkele vonnissen hem in het gelijk te stelien $(* 21)$. Tot het sluiten van overeenkomsten met sommige derden acht hij de architekt echter niet bevoegd. De bedoeling van partijen sluit zijns inziens slechts in dat de architekt niet alleen wederpartij is tegenover de a nnemer, mar soms ook tegenover leveranclers en onder bepalde onstandigheden tegenover de bouwpolitie en de overheld. Noolt echter tegenover derden-buitenstanders, wanner het begtek hem daartoe niet machtigt.

De "ondeskundigheid" van de principal is underdaad zeer lang bepalend geweest voor de status van de architekt in juridische zin. Ook zonderland (*22) baseert zich bij zijn detinitie van de architektenovereenkomst op deze

onwetendheid:

"de architektenovereenkomst is die overeenkomst, warbij de ene partij (de architekt) zich tegenover de andere partij (principal) tegen betaling verplicht om als deskundige op het gebied van de bouw van oncoerend goed ten behoeve van de principaal al datgene te verrichten wat deze laatste zelf niet verrichten kan or een 
volwardige tegenpartij te zijn van de derde foe aannemer) die de bouw tot stand brengt in diens relatie tot de bouwheer".

Het zal duidelijk zijn dat deze negatieve benadering thans in zijn algemeenheld, als kriterium in een sluitende definitie van de architekten-overeenkomst niet meer kan gelden. Een belangrijk deel van de professionele opdrachtgevers is thans valk even deskundig als de architekt, de vormgevende aspekten uitgezonderd. Veeleer zal dat deel van de overeenkomst architektprincipal (i.c. voor wat betreft de uitvoering) worden beheerst door de koppeling van de technische aspekten van de uitvoering aan de ard van het ontwerp van de architekt, derhalve als logisch uituloeisel van de ontwerpoparacht en niet vanwege de onkunde van de opdrachtgever. De architekt wordt uit hoofde van zijn opdracht verplicht vanwege de aard en uitvoerbaarheid van het ontwerp en de dárvoor met de aannemer overeengekomen prijs.

\section{III.2.1.2}

de vertegenwoordigingsbevoegdheid van de architekt

De vertegenwoordigende rol van de architekt bij de uitvoering was redelijk evident voor wat betreft de uitvoerende taak, niet echter als het op betalen aankwam. Talloos zijn de procedures over opgedragen meer- en minderwerk en afgegeven certifikaten van betaling, kortom, de financiële kant van de aannemingsovereenkomst.

De vraag of vorderingen uit hoofde van meerwerk werden erkend scharnierde om de interpretatie van $1646 \mathrm{BW}$, welke schriftelijke meerwerkovereenkomsten elste. Uitzonderingen op dit wetsartikel werden niet gedoogd, ook niet door middel van getuigenverklaringen onder ede. zulke verklaringen werden principieel geweigerd omdat $z i j$ terzijdestelling zouden inhouden van de nadrukkelijke wettekst van 1646 BW (*23). Ook het opmaken van de verrekenstaten door een architekt impliceerde nog geen betalingsplicht voor de opdrachtgever. Mr. I. Limburg bepleit daarom en wijziging van de desbetreffende wettekst in "door den a anbesteder of architekt". In dit verband zij nog eens gewezen op de bijzondere rechtspositile van de architekt na besteding, dus als directievoerder op het werk. Hij treedt dan immers als gemachtigde, als lasthebber en vertegenwoordiger van de aanbesteder op ten opzichte van de annemer. Een dergelijke lastgeving geschiedde destijas zelden uitdrukkelijk terwijl deze vrijwel nooit tevoren aan de a annemer werd kenbaar gemakt.

Bovendien zag de a anbesteder hier ook valk een reden tot chicanes en ontkende hij de bevoegaheid van de architekt sowieso. Dat gold nog sterker voor goedgekeurde betalingscertifikaten. 
Deze onduideIjjke rechtspositie van de architekt rond 1910 tussen aambesteder en aannemer in, heeft vele juristen hoofdbrekens bezorgd. Geen wonder dat deze positie de konsistentie van de jurisprudentie zelfs aan het wankelen bracht. Een vonnia van het Hof Den Haag in 1908 wees een aannemersvordering tot betaling van termijnen af. Dit op grond van het feit dat een algemene ansteling van de architekt slechts kon strekken tot zijn benoeming als caadsman van de opdrachtgever met voorlichtende funktie en dat de verklaring van zo een "raadsman", de opdrachtgever dus niet bond. Bij vonnis van de Rechtbank Amsterdam in april 1910 werd ondermeer overwogen dat de architekt weliswar nilet als bevoegd "in alle opzichten" kon worden gezien, mar dat de eis aan de aannemer moest worden toegewezen op grond van par. $494 \mathrm{AV}, 466 \mathrm{AV}, 468 \mathrm{AV}, 476 \mathrm{AV}$. Beide rechterlijke beslissingen leggen echter de beoordeling van het geleverde werk in handen van de a anbesteder, $1 . c$. een leek.

Mr. E.J.C. Goseling wijdt aan deze kwestie een uitgebreid artikel in het Bouwkundig Weekblad (* 24) en grijpt daarin terug naar de definitie van de architekt door 1 'Academie Française van 1835 warin de woorden "il fait executer sous ses ordres" in zijn ogen een duidelijke markering bood van de allesoverheersende positie van de architekt. Gezien de maatachappelijke ontwikkelingen rond de architekt sinds die tijd is dit teruggrijpen naar 1835 niet sterk. Juist de diskussie cond 1645 BW heeft voor deze "architecte" neer een aannemer laten zien dan wat men ook rond 1910 onder architekt verstond in Goselings zienswijze.

Hij voerde de vraag rond de bevoegdheid van de a anbesteder tot het finale oordeel over de aannemersprestatie terug op het rechtskarakter van de overeenkomst tussen architekt en aanbesteder enerzijds en aanbesteder en aannemer anderzijds. Weliswar bouwde hij zijn betoog op rond de "huur en verhuur van diensten" doch stelt daarbij de ondeskundigheid van de aanbesteder centraal.

Daarnaast echter haakte hij meer in op de kungtzinnige kant van de zaak. Dát ontwerp is door de opdrachtgever gewild en dús moet de architekt de vrije hand hebben om dát ontwerp tot in de details uit te voeren. Een visie vanuit de centrale rol van de architekt.

Het Hof elste echter een volmacht van de aanbesteder tot goedkeuring en vond de termen van de wederzijdse overeenkomst architekt-bouwheer daarop te weinig toegespitst. Goseling zag vooral in het intellectueel karakter van het werk van de architekt een reden tot "vrijheid van handelen", een onbegrensd werkgebled, maar verloor uit het oog dat uitvoeren van werk een materieel karakter draagt. War hij ingaat op de rechtsverhouding aanbesteder-aannemer komstateerde hij dat, omdat de aannemingsovereenkomst bij bestek vermeldt "naar het plan van architekt $x$ en onder diens leiding en toezicht", de aannemer zich daardoor ook verbond jegens de architekt. 
Hij duidde op het belang van de architekt en keuse vanwege de invioed die een bepalde architekt op de inschrijving van een aannemer kon hebben. Wellicht is dit onderscheid eerder terug te voeren tot de rechteloosheid van de aannemer in die tija. De architekt was voor hem immers een primaire risikofactor, de anbesteder een sekundalre. Het schijnt overigens voorgekomen te zijn dat architekten tijdens de uitvoering werden afgedankt vanwege een veconderstelde coulante houding ten opzichte van de aannemer en dat de aannemer daarop de uitvoering staakte. De besteksinterpretatie door de architekt was immers doorslaggevend. De aannemer die de architekt "kende" wist welke risiko"s hij liep. Een wijziging in de direktievoering, en dat zal zelden zijn gebeurd omdat de architekt tevéel oog had voor het opdrachtgeversvoordeel. verhoogde de financiële risiko"s woor de aannemer dus zeer aanzienlijk.

In een vonnis van de Rechtbank te Amsterdam (niet gepubliceerd) werd de afkeuringsbevoegdheid wel an de architekt geacht te zijn gegeven, wanneer de AV van Waterstaat teminste van kracht was verklaard (par. 468. 476, 494) In deze paragrafen stat dit overigens mergens uitdrukkelijk vermeld. Sommigen zagen in het ontbreken van opneming en goedkeuring in de opsomming van de werkzaamheden van de architekt (*25) de motivering van "s rechters twijfel aan de architektenbevoegaheid tot goedkeuring van de aannemersprestatie.

Op de jaarvergadering van de NAB (* 26) van 12-07-1911 stelde de voorzitter J.N. Hendrix dat de architekt in het aannemingskontrakt, juridisch gezien, in een buitenspelsituatie verkeerde.

Ten aanzien van de goedkeuring van betalingscertifikaten door de architekt is het kommentaar uit 1918 (*27) van mr. E.J.C. Goseling op een publikatie van mr. I. van Creveld nog interessant. Van creveld stelde n.l. in zijn gebundelde opstellen "de overeenkomst tussen Bouwheer en den Architect de bevoegdheid var de architect in deze "als regel"

a anvarabare, mar niet altijd. Goseling verwees nar het dagelijks toezicht en zag alleen in het ontbreken van goede trouw bij de architekt reden om de betaling te weigeren. valgens hem stelt art. 1374,1 id 3 BW de goede trouw verbindend en vormt dus het criterium, Van creveld verschilde daarin met hem van mening omdat de bevoegdheid zelve ter diskussie staat, los van de goede trouw.

Hij, Van Creveld, konstateerde dat vooral de technische kant van het architektenvak steeds gekompliceerder werd wardoor zijn dienst an de a anbesteder steeds verder uitsteeg boven de raadsman-status en dat derhalve meer van een gemachtigde moest worden gesproken. Dat deze gemachtigde de bevoegdheid ontbrak om wijzigingen in thet oorspronkelijk kontrakt van anneming an te brengen, of zelfstandig oparachten te verstrekken, werd als en ernstig 
manko ervaren, ook door de a annemerij. Herkwardigerwijs blijkt uit Hendrix" betoog dat veelal buj bestek werd bepaald dat de a annemer én de architekt als "directie" dienden te worden beschouwd. In deze tifd was de aanbesteder nog en volslagen leek op bouwkundig gebied. die enerzifds de architekt als directie aanwees wiens orders moesten worden opgevolgd, doch anderzijds als het op betalen aankwam zelf besilste omtrent het al of niet rechtmatig zijn van de vordering. Met het voorstel wan de nieuwe ontwerp-AAV (zie hoofdstuk III.4.3) van de commisie (VDI, Matschappij, NAB) werd weliswaar een belangrijke stap gezet in de gelijkberechtiging van aannemer en aanbesteder, de positie van de architekt veranderde darardoor niet wezenlijk.

Een speciaal aspekt van a ansprakelijkheid van de architekt deed zich voor bij de opkomst van de gewapend-betonbouw. ondat deze technische ontwikkeling toen nog geen deel uitmakte van het opleidingspakket van de architekt was de berekening een aannemersaffaire die daarvoor een konstrukteur inhurde. Deze werkte als onderaannemer en was bij ondeugdelijke uitvoering ongrijpbaar voor de besteder. Mr. K.H. van Nieuwkerken wijdde in 1912 an dit probleem een beschouwing (* 28) warop de architekt Jos Cuypers repliceert (* 29) dat noch de architekt, noch bouw- en woningtoezicht aansprakelijk kunnen worden gesteld voor het konstruktieve werk. Wat de gemeentelijke instanties betreft konstateerde van Nieuwkerken dat een administratieve rechtspraak ontbrak on deze aansprakelijkheid vast te stellen. De aansprakelijkheid van de architekt bleef dus steken in de diskussie van vakgenoten.

Terecht stelde Van Nieuwkerken de dualistische positie van de architekt te kijk: enerzijds toezien, anderzijds leiden. Immers zowel het én als het ander berust bij "de directie".

Ter verduidelijking voerde hij an dat er bij overlijiden van de architekt in de rechtsverhouding a anbestederaannemer in wezen niets veranderde. De aannemer kon bovendien geen rechten doen gelden ten aanzien van leiding en toezicht, waraoor de a ansprakelijkheid van de architekt sekunda is ten opzichte van de aannemer, althans voor zaken buiten de feltelijke ontwerp-oparacht.

Voorts kritiseerde van Nieuwkerken het in het ontwerp gehanteerde beginsel dat de annemer niet aansprakelijk kon worden gesteld voor de gevolgen van het voldoen aan de bevellen van de direktie. Naar zijn mening werd daarmee het technigch kunnen van de aannemer in twijfel getrokken. De konklusie luidt dat het passeren van het advies van de architekt in zaken de bouw betreffende in de eerste plats leidt tot de bewijslast bij principal/aanbesteder, dat door de architekt onzorgvuldig is gehandeld bij het opstellen van zijn advies.

Van Nieuwerken konstrueerde ten aanzien van ontwerpfouten via de eliminatie-theorie (niet opdragen van bouwleiding en toezlcht) een volstrekte niet-aansprakelijkheid hiervoor 
van de architekt. Hij verwees daarbij tevens naar de duitse praktijk van die dagen. De aannemer blijve aansprakelijk voor vergissingen die v68r de uitvoering door hemzelf "makkelijk" hadden kunnen wotden onderkend. Vermeden moest worden dat de directie verwerd tot een soort intellectuele uitvoerder al werd door hem wél een ontwikkeling in die richting gesignaleerd.

Het al of niet gemachtigd zijn van de architekt om meerwerken op te dragen zonder schriftelijke toestemming van de aanbesteder dacht Van Nieuwkerken op te lossen door middel van de "zakwaarneming" (1390 BW e.w.). Dit houdt in dat in bijzondere gevallen zonder machtiging verplichtingen kunnen worden aangegaan voor derden.

Wel was zijn opmerking terecht dat een toevoeging wenselijk was in die zin dat de directie opdrachtbevoegdheid heeft wanneer de deugdelijkheid in het geding is, $b f$ wanneer hij daartoe door aanbesteder werd gemachtigd. Die last diende schriftelijk te geschieden, behoudens in geval van schade bij langer uitstel. Een merkwaraige regel in de nieuwe ontwerp-AAV was de ontbindende kracht van gebleken "onuitvoerbaarheid" van de plannen. Kennelijk kwam dat wel voor hetgeen een eigenaardig licht werpt op de plannenmakers. Overigens stelde Van Nieuwkerken dat de a annemer $z i c h$ van die onuitvoerbaarheid had kunnen overtuigen v68r de besteding. Hij zag daarbij over het hoofd dat de juistheid van die stelling stat of valt met de kwaliteit van de bestedingsstukken. De mogelijkheid van ontbinding opende voorts al de mogelijkheid van schadevergoeding door de aannemer hetgeen ongewenst werd geacht, omdat architekt en aannemer in dit geval immers tezamen schadevergoedingsplichtig zouden zijn. Zelfs een verkeerde architektenkeus kon de opdrachtgever, als volslagen leek, niet worden tegengeworpen.

De bevoegdheid tot opneming en goedkeuring was, zoals al gesteld, een omstreden architektenbevoegdheid. De bevoegdheid werd door de rechtbank Amsterdam in 1901 (*30) erkend, maar bracht toch geen betalingsplicht met zich mee, daarvoor was "een termijn van vier weken" gebruikelijk. De Rechtbank in Rotterdam in 1846 (*31) huldigde het stand punt dat het ontbreken van afkeuring nog geen goedkeuring inhoudt, een standpunt dat decennia is gevolgd.

Het Hof te Den Haag 02-11-1908 8789 oordeelde in 1908 (* 32 ) de architekt niet bevoegd vanwege het ontbreken van een uitarukkelijke machtiging. Het nieuwe ontwerp AV 1911 versterkte de positie van de architekt door te otelien dat de architekt de gemachtigde is van de anbesteder. Kritiek was er wel, omdat hiermee meer problemen werden geschapen dan opgelost.

Afkeuren van gemakt werk door de architekt lag impeler en gaf minder problemen (*33). De rol bij het afgewen van betalingscertifikaten op zichzelf werd niet essentieel. 
geacht door de rechtbank zierikzee in 1911 (*34), slechts het volbrengen van de bedongen prestatie is van belang. niet wie dat beoordeelt.

Van Meuwkerken stelde dat de architekt ansprakelijk diende te zijn voor vergoeding van door de besteder geleden of te lijden schade als gevolg van een verloren gegaan verhalsrecht op de aannemer. Tenminste als het nieteffektief zijn van dat recht door des architekts onvermogen tot een juist oordeel over de prestatie van de aannemer werd veroorzakt.

In de ontwerp-AAV 1911 werd de "zorg voor wettelijke belemmeringen bij de directie" en dus de architekt, gelegd. Dus ook de aansprakelijkheid voor het ontbreken van de vereiste vergunningen. Die verantwoordelijkheid schijnt wak doorgeschoven te zijn naar de aannemer via de machtiging door de aanbesteder an de architekt verleend. Bij tijdens de uitvoering optredende problemen was de enige uitweg voor de annemer, de "onuitvoerbaarheid" als ontbindende voorwarde in het kontrakt.

\footnotetext{
"Gemeente- of andere verordeningen en wetsbepalingen moeten stipt door den Aannemer in acht worden genomen, komende alle kosten of schade wegens niet naleving daarvan voor zijne rekening. Verder zal hij eigenaars van belendende percelen bij Deurwardersexploit op gebruikelijke wijze kennis geven van den voorgenomen bouw."
}

(uit het bestek van een architekt voor de bouw van een kantoorpand te Amsterdam in 1914).

In zijjn inaugurele rede bij zijn ambtsaanvaarding bij de Technische Hogeschool te Delft van 08-10-1915 merkte prof. ir. Chr. K. Visser c.i. op dat op dat ogenblik zeer slordig werd omgesprongen met bestekteksten, terwijl de tijd voor de prijsvorming tot een minimum wera teruggebracht. Hij duidde op het verschil in betekenis van architekten-en a annemersbegtoting. De eerste is indikatief, de latste bindend met grote risiko's in de bedrijfssfeer.

Hij verweet de architekten gebrek aan zelfstandigheid en vees voor het a anvarden van verantwoordelijkheden. Men distantieerde zich $0 . a$. bij het opnemen van bestekshoeveelheden voor de juistheid van de opgave. Wisser laake de tijd-en geldverspliling door het ontbreken van uniforme hoeveelhedenstaten en tevens het gebrek aan detailtekeningen bij het bestek en laakte het verwijzen naar "luter" nog te vervardigen exemplaren. Vele architekten bleken de ware inspiratie pas ná gunning te vinden en zich dan wit te leven in bewerkelijke detalis. Visser bepleitte de vaststelling van vaste verrekenprijzen. ook bij geheide fundaties deden zich vreemde zaken voor zoals het korten van de aanneemsom voor niet ingeheide pallengten. Het voorkomen van deze misstanden kan worden afgeleid uit de triomfantelijke melding van de verrekening 
in goed overleg wan de overlengte van 23000 palen

(14-17 meter) voor de zuidergasfabriek te Amsterdam.

Een 1 ijst van eenheidsprijzen werd door de architekt opgesteld bij aanneming, éénzijdig, en konflikten daarover waren an de orde van de dag. Visser" pleidooi voor het inleveren van die specifikatie door de aannemer bij de besteding, is dan ook voor huidige begrippen niet meer dan $\operatorname{logisch}$.

De rechtspositie van architekt en aannemer bij de uitvoering van bouwwerken is ook in 1921 nog vollop in diskussie bij de architekten zelf, getuige het betoog van de destijds zeer bekende architekt Jan Gratema (*35). volgens $z i j n$ visie berustte in geval van onvoorwardelijke aanvaarding van de bestedingsstukken door de annemer de volle verantwoordelijkheid voor de bouw op deze laatste. Hij beschouwde de toezichthoudende rol van de architekt als een analogon van de "bouwpolitie" en direktie. Derhalve heeft $z . i$. de aannemer de leiding van de uitvoering en niet de architekt of de opzichter; daar hoorde dan ook de verantwoordelijkheid thuis. Hij beschouwde het geestelijk werk als hoofdtaak van de architekt en komt daarmee weer in het spanningsveld terecht van vorm en techniek. Daarmee werd echter door hem voorbijgegaan aan de kwintessens van het vraagstuk, namelijk het al of niet uitvoerbaar zijn van de bestedingsstukken.

Hij pleitte voor een stringente normering van de architektentaak. Konsekwent redenerend stelde hij dat óf aan de architekt een risikodeel in de honorering wordt toegekend $6 \mathrm{f}$ dat hij gevrijward dient te worden tegen schadevergoeding en alleen kan worden beboet bij wanprestatie.

Interessant is een arbitrale beslissing in 1916 voor wat betreft de ansprakelijkheidsfilosofie (*36). De aannemer kreeg de bouw van een kerk met pastorie opgedragen onder leiding en toezicht van de architekt. Na voltooiing vertoonde het bouwwerk ernstige tekortkomingen, de schade bedroeg 40\% van de anneemsom. Het oordeel van de arbiters ging over een viertal soorten tekortkomingen:

1 niet voltooien van de bouw

- annemer ansprakelijk:

2 gebreken van gebrulkte materialen

- primaire aansprakelijkheid van de aannemer,

- sekundair architekt vanwege onvoldoende toezicht:

3 foutieve konstrukties

- aansprakelijkheid architekt

4 fouten als gevolg van het niet volgen van de voorgeschreven konstrukties of anwijzingen van de direktie

- beiden aansprakelijk voor gelijke delen 
Over punt 3 kan nog worden opgemerkt dat de architekt bij bestek lle ansprakelijkheld had afgewenteld op de aannemer. Arbiters oordeelden dit in strijd met de goede zeden en dus nietig. Rosenboom vocht deze stelling aan op grond van de "warschuwingsplicht.

III. 3

De bultenkontraktuele rechtspositie van de architekt

I I I. 3.1.

de architekt en de onrechtmatige daad

In hoeverre kan een architekt a ansprakelijk zijn tegenover derden op grond van onrechtmatige daad bij de uitvoering van werken? Mr. E.H.P. Rosenboom lilcht in 1925 in een artikel (*37) de strekking toe van 1401 BW . v. terzake van oncechtmatige daad en de uitbreiding daarvan als gevolg van het arceat Lindenbaum/Cohen in 1919 (*38). Deze uitbreiding hield in dat, niet alleen handelen in strija met de wet onrechtmatig werd geacht, maar ook het handelen in strijd met ieders rechtsplicht tegenover derden. Dat makte vorderingen inzake onzorgvuldig handelen wardoor schade aan belendingen ontstond tot een haalbare zaak. Natuurlijk trachte men ook misbruik te maken, mar de regel werd niet à tort et a trawers gevolgd, getulge het feit dat een eiser wiens uiterst bouwvallig belendend pand instortie, in het ongelijk gesteld werd (*39). Een analoog geval diende in 1922 te Rotterdam en werd op gelijke wijze afgehandeld.

Darentegen deed $z i c h$ in de procedure voor de Rechtbank te Ansterdam in september 1924 het tegenovergeatelde voor. De bouwende partij kreeg geen vergunning vanwege de bouwvallige stat van de belending. Gedaagde (belending) stelde geen noodzatak te zien de gtutwerkzaamheden uit te voeren ook niet op kosten van de eisende partij, omdat zijn eigendomsrecht daardoor ernstig zou worden geschaad. Het vonnis luidde anders. Dok hil had rekening te houden met de redelijke belangen van de buurman en werd tot schadevergoeding (vertraging in de bouw) veroordeeld.

ult écen ander blijkt dat niet alleen het niet ontzien van rechten tot veroordeling leidt, doch ook de verwarlozing van rechtsplichten en het voorbij gaan aan de redelijke belangen van medeburgers.

In hoeverre was de architekt bij dit alles betrokken? In het vonnis van de Rechtbank te wolle in 1913 (niet gepubliceerd), wordt verwezen nar de grondslag van de rechtsbetrekking tussen architekt en annemer, namelijk het bestek en voorwarden. In de darbij toepasselijk verklaarde AV van Van der kloes, werd in verschillende artikelen de aannemer gelast zich stipt naar de anwijzingen van de direktie te gedragen. De rechtbank konkludeerde hieruit dat de annemer in deze dus niet 
zelfstandig handelde en dus als "ondergeschikte van de Direktie in de zin van 1403 BW was te beschouwen. Niettemin oordeelde de Rechtbank dat dit de eigen verantwoordelijkheid van de annemer niet integraal opheft, omdat zijn zelfstandigheid groot genoeg was om krachtens 1402 en 1403 BW ook zélf aansprakelijk te kunnen worden gesteld. Aldus werden zowel architekt als aannemer aansprakelijk geacht, zij het op verschillende rechtsgronden.

In tegenspraak hiermee is het arrest van het Hof te Amsterdam in 1921 dat de verantwoordelijkheid van de aanbesteder ingevolge 1403 BW bevestigde op grond van eigen verantwoordelijkheid voor eigen handelen. Ook de Hoge Raad besliste in 1917 (* 40) dat de anmemer niet als ondergeschikte kon worden gezien. De Hoge Raad overwoog in dit arrest voorts dat het simpele feit van aanbesteding de besteder niet ontheft van alle verantwoordelijkheden, zeker niet als deze als een logisch uitvloeisel van het uitvoeren van het bestek kan worden gezien. Het betreft dan niet zozeer de uitvoering zélf mar de ara van het werk, waardoor aambesteder mee-aansprakelijk wordt: Rosenboom echter zag niets onbehoorlijks in een besteksclausule warbij aanbesteder $z i c h$ vijwarde tegen aanspraken van derden. In thet vonnis van Rechtbank Amsterdam in 1915 (* 41) deed $z i c h$ inderdad een geval van vrijwaring voor ingevolge een dergelijke besteksbepaling, omdat een dergelijke vrijwaring ook duidelijk was gewild, en bij het aangaan van de overeenkomst door de wederpartij was aanvaard. Een nevenrol speelde de omstandigheld dat de Rechtbank hier geen onderscheid wilde maken tussen schade als gevolg van de uitvoering en die naar de ard van het werk. De schade was namelijk opgetreden bij de uitvoering en hield daarmee ten nauwste verband. Géen uitvoering zou ook geen schade hebben betekend.

Primair zou bij schade aan belendingen van derden de aannemer worden aangesproken en eventueel de besteder. En wat was de positie van de architekt? van een directe aansprakelijkheid bij belendingsschade door derden $z$ a niet gauw sprake zijn. Dat zou o.a. Wel mogelijk zijn als de schade was opgetreden als gevolg van bevelen tot handelen of zulks nalaten van de directie angaande de ultvoering, met dacaan gekoppelde besteksverplichtingen om dergelijke bevelen op te volgen (AV Van der Kloes). Maar zelfs dan zal, wanneer de rechtsverhouding architekt-aanbesteder er een is als lasthebber en -gever de laatste aamspakelijk bilijuen.

Wel mogelijk is een verhalen van de schade door de besteder op de architekt in tweede instantie, mar dat is theorie, oordeelde de Rechtbank Den Haag in 1914 (* 43).

Niet onvermeld mag blijven de cause-célèbre Salters/Vas Dias HR 6/526, NJ 1926/721, van 1926 warbij de architekt herstel toezegde aan de eigenar van een belendend perceel dat door bouwwerkaamheden was beschadigd, warbij de HR 
oordeelde dat de anbesteder hierdoor niet gebonden was omdat deze zijn wl dartoe niet zelf kenbaar had gemakik.

In 1932 halde nog een belendingenprocedure de pers (* 44). ook hier een eis tot schadevergoeding voor de beschadigde belending, warna verweerster (besteder) zich beriep op de zelfstandigheid van zijn a nnemer (krachtens art. 1403 BW). tevergeefs, de rechtbank wees de vordering toe amdat gewerkt werd volgens bestek en aanwijzingen van verweerster, en de schade daar noodzakelijkerwijs uit voorcvloeide. Eiser werd echter niet-ontvankelijk verklaard omdat het voldoen van zijn vordering niet was geëist. Het Hof bekrachtigde dit vonnis in beroep omdat juist de strikte arwijzing van besteder aan aannemer het scharnierpunt vormae en daarvan in de dagvading niets bleek. De kommentator zag in dit geval van juridische haarkloverij een aanleiding voor een pleidooi voor arbitrage.

$\operatorname{III.3.2}$

het ateurgrecht met betrekking tot de bouwkunst

Voor de integrale behandeling van dit onderwerp zij verwezen naar hoofdstuk VI.

III. 3.3

titel- en beroepsbescherming

Zoals reeds in hoofdstuk II.1.1 is uiteengezet leidt de ontwikkeling van de wettelijke bescherming van het architektenberoep niet tot voor de rechtspositie van de architekt bepalende elementen. Het daartoe strekkend wetsontwerp bleef tengevolge van het uitbreken van de mweede Wereldoorlog in de Kamerbehandeling steken.

\section{II . 4}

De rechtspositie van de annemer en zijn relatie met de architekt

\section{$\operatorname{III.4.11}$}

inleiding

Wanneer de rechtspositie van de architekt wordt bezien kan die van de alnemer niet buiten beschouwing blijven. Zoals wij in voorgande paragrafen reeds zagen is immers de kontraktuele relatie van de annemer met de opdrachtgever er in feite een met diens vertegenwoordiger - de architekt. De architekten hebben in die hoedanigheid een vaak

ambivalente rol gespeeld, niet als persoon, mar wel als beroepsgroep. Immers, als deskundig raadsman van ondeskundige opdracht-

gevers waren zij het die de besteksvoorwarden formuleerden die kwetsend waren voor het rechtsgevoel. Anderzijds waren er die zich uit gevol voor sociale rechtvaardigheid geroepen voelden om a an die omstandigheden iets te doen. 
Hun inzet heeft geleld tot een betere rechtspositie van het uitvoerend bouwbedrijf.

ook hebben BNA-architekten zich bezig gehowden met het totstandbrengen van een verbeterde geschillenbeslechting, terwijl ook een bijarage werd geleverd aan de verbetering van de formulering van de ontwerp- AAV 1911, die van groot belang was voor de bepaling van de rechtspositie van de aannemer.

Tenslotte ontstaat een situatie rond de jaren dertig, warin de aannemer zich ontwikkelt tot oparachtgever van de architekt.

III. 4.2

de rechtsongelijkheid van opdrachtgever- en a anemer rond 1900

Deze rechtsongelijkheid werd in feite veroorzakt door het in Hoofdstuk I.2.2 reeds gesignaleerde kwaliteitsverval in de ambachtelijke sfeer na het afschaffen van de gilden. Te velen waren immers bereid het met de kwaliteit van hun werk op een akkoord te gooien terwille van de omzet, de tijden waren slecht. Knoeierij en bedrog kwamen veelvuldig voor. Dat de opdrachtgevers zich daartegen wapenden ligt voor de hand. Bestekken en toezicht werden zodanig ingericht dat het risiko ervan tot een minimum werd beperkt. Reeds in 1815 worden door de dienst van het corps Ingenieurs der Genie bij Koninklijk Besluit de "Algemene Voorwarden" vastgesteld "voor alle bestedingen of contracten, gedaan of aangegaan wordende tot de uitvoering van werken of het doen van leveranties voor den dienst der fortificatiën, van kracht zijnde, alsof zij woordelijk waren vervat in de bestekken of conditiën tot dezen dienst betrekkeli jk" .

Voor Binnenlandse Zaken, en wel in thet bijzonder voor de derde afdeling van dit departement, de waterstaat, werden soortgelijke regelen per ministeriële beschikking van 14 Februari 1839 van kracht verklaard. Deze vookwarden zijn in de periode tot 1930 vele malen gewijzigd en a angepast (zie hoofdstuk I.2.4). Omdat al spoedig ook partikulieren de derde afdeling der AAV, namelijk de Administratieve Bepalingen, gingen hanteren ontstonden kontraktuel relaties tussen a annemer en principal die vak strijdig waren met het rechtsgevoel. Konflikten bleven dan ook niet uit.

I I I . $4 \cdot 3$

architekten stellen de misstanden aan de kak

De architekten voelden $z i c h$ geroepen om tussenbeide te komen. De lezing van de architekt F.J. Nieuwenhuig voor de Maatschappij tot Bevordering der Bouwkunst afdeling Rotterdam in januari 1884, leidde de diskussie in, die het jaar daarop ook door de aannemerssocięteit "De Nijverheid" 
in Den Hag werd opgepakt. Om duidelijk te doen overkomen wat de kwintessens was van Nieuwenhuis' betoog en de relevantie ervan, is het noodzakelijk enige a nhalingen te doen uit de bepalingen van die tija. Het is vooral de kombinatie van artikelen in de AAV 1882 die de rechtsongelijkheid deed ontstaan. 


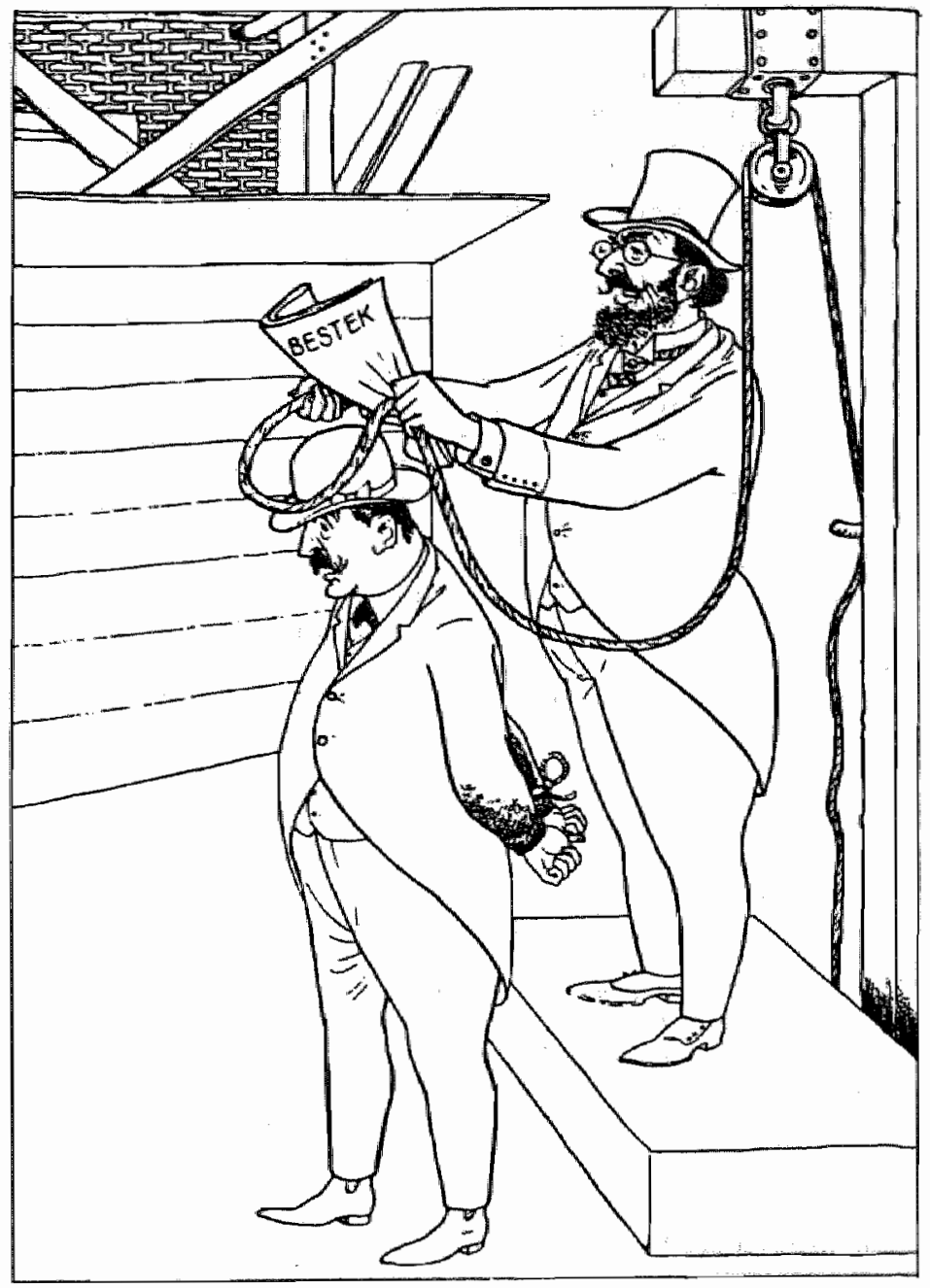

Tekening van Jan Rot, vermoedelijk betrekking hebbend op de vroegere underdogpositie van de aannemer, samengevat in de twee artikelen.

1. De aannemer wordt opgehangen.

2. De aannemer betaalt zijn eigen strop.

De tekening komt voor in een gedenkboek over de geschiedenis van de Ned. Aannemers - en Patroonsbond NAPB en 1 s ook opgenomen in het jubileumboek van de Raad van Arbltrage voor de Bouwbedrijven in Nederland. 
par. 453: de aannemer is verplicht het werk uit te

ild 1 "roeren naar de bepalingen van het bestek en wolgens de bevelen en aanwjingen, die hem door de drectie gegeven worden, en te zorgen dat daraan ook door zijne onderhorigen ....enz." A. 1882

par. 442: "het gehele werk voor rekening en risiko van de annemer $1 \mathrm{~s}^{\prime \prime}$.

par. 443: "Indiendoor storm, vorst, ijsgang, buitengewoon hoog- of laagwater, dijkvallen, brand, regen, onteigening of andere omstandigheden

onafhankelijk van de wil des aannemers, zoodanige vertragjingen worden veroorzaakt dat hij buiten staat is het aangenomene op den bepalde plaats te leveren en te voltoolen, wordt het a antal dagen dat de aannemer niet heeft kunnen werken bij de toepassing van de kocting (par.451) niet in a nmerking gebracht en dat voorzoverre de directie overtuigd is dat het oponthoud werkelijk buiten de schuld van den aannemer en zijne ondergeschikten heeft plaatsgehad. Terzake van zoodanig oponthoud wordt den aannemer geen schadevergoeding hoegenaamd verleend" (AAV 1882). par. 446: bij nieuwe werken of gedeeltelijke

lid 2 "herstelling van bestaande werken komen al die schaden daaraan tijdens de uitvoering ten laste van den aannemer, met uitzondering van dijkvallen" (AAV 1882).

par. 447: "alle afschuivingen, verzakkingen of verzinkingen bij de uitvoering van aarde- of hijswerken ontstaan, komen ten laste van den aannemer en worden voor zijn rekening hersteld" (AAV 1882). par. 445: "evenmin ontvangt de aannemer vergoeding voor onvoorziene uitgaven of uitvoeringen, die te beschouwen zijn als een noodzakelijk gevolg van de uitvoering der werken zellve en van het behoorlijk gebruik der bouwstoffen". (AAV 1882).

par. 453: "hij (aannemer), is persoonlijk verantwoordelijk voor alle bedrog, beschadigingen, verkeerde handelingen enzovoorts, betrekkelijk de werken gepleegd door zijn gemagtigden, onderbazen, verdere beambten en arbeiders. Alle daaruit voortvloeiende kosten komen yoor zijn rekening. Alle schade van welken aard ook, door de ultvoering van de vernieuwingen, herstellingen en onderhoudswerken, door de schuld van de annemer aan gebouwen of andere werken taegebracht, wordt door hem, ten genoege van de directie, hersteld en in orde gebracht". (AAV 1882).

par. 468: ongelukken worden op des aamnemers schouders afgewenteld

par. 461: "eveneens alle onkosten, voortvloeiende uit lokale politieverordeningen".

vooral dit artikel was aanleiding tot veel geschillen die 
doar de rechter werden beslist. Lokale verordeningen luidden overal anders.

Het was Nieuwenhuis" vaste overtuiging dat, zo er van schuld van partijen in het algemeen sprake was, deze voornamelijk moest worden gezocht bij de makers van de bestekken (* 18). Hij bepleitte de volgende hervormingen:

- dat de aannemer gewarborgd werd voor al zijn bij de wet toegekende rechten:

- dat de aannemer niet aansprakelijk gesteld kon worden voor schaden, ontstaan uit fouten of onvolledigheden in de plannen, voorgeschreven materialen of het gebruik daarvan, indien deze niet door hemzelf waren geleverd;

- de aannemer ontheven werd van verantwoordelijkheid voor schaden, toegebracht door oorzaken die menselijkerwijs niet in zijn handen lagen:

- de eindbeslissing bij geschillen niet gelegd worde in de hand van één der partijen alleén, zoals feitelijk bij het beroep op de Minister van Waterstaat (het enig toegestane bij geschillen) het geval was;

- dat meer rekening worde gehouden met de gebreken van natuurlijke materialen in die zin, dat geen overdreven eisen worden gesteld voor het gebruik van die materialen en alleen schadelijke of gebrekkige materialen worden geweerd en dat, waar material. zonder gebreken absoluut verlangd wordt, zulks zeer bepald in een bestek wordt a angewezen zodat daarop kan worden gerekend;

- verlaten van het de facto bestaande recht van de laagste inschrijver om deswege het werk te verkrijgen, maar om evenals bij partikuliere koop het anbod en de anbieder in direkt verband met elkar te beschouwen:

- betere besteksomschrijvingen, waarbij de bedoeling van de ontwerper duidelijker naar voren komt door toevoeging van details, modellen etc. en war zo weinig rogelijk aan schattingen behoeft te worden overgelaten.

Men bedenke hierbij dat het hier primair ging om rechtsongelijkheid tengevolge van de AAV van Waterstat, dus in feite de Nederlandse stat. Zo schreven deze o.a. voor dat na het overlijden van de aannemer diens nabestaanden verantwoordelijk bleven, ondanks borgstelling, en van het voorrecht van schuldsplitsing afatand moest worden gedaan alsook uitwinning, gerechtelijke in-gebreke-stelling en verzuim.

Hoewel dat aanvankelijk in de dagelijkse praktijk warschijnlijk niet zoveel problemen opleverde werd, door de zich wijzigende matschappelijke verhoudingen het artikel $442 \mathrm{AAV}$, waarbij "het geheele werk voor rekening en cisjko van den annemer is", tot een oorzaak van 
rechtsonzeketheid van de annemer. Blijkens wieuwenhul ${ }^{\prime}$ betoog werd van dit artikel zeer veel misbruik gemakt om de gevoligen van slechte en onvolledige plannen naar de ulituerenden door te schuiven.

Kwam het eenmal tot een geschil dan werd dit door de directie besliat behoudens appèl op de Minister van Waterstatat (45) wiens onpartijdigheid per definitie ontbrak, vooral bij Rijkswerken.

Lang niet altijd kwam het echter tot geschillen in juridische zin. Veel erger was het misbruik dat door het toezicht of opdrachtgever op het werk werd gemakt van deze rechtsongelijkheid. Tyrannieke situaties waren an de orde van de dag.

Ten a anzien van Nieuwenhuis' pleidooi voor een genuanceerde gunningsmethodiek door het voorbijgaan aan de laagste inschrljver, kan worden opgemerkt dat par. 437 der toenmalige AAV dat zeker toestond omdat daarin gesproken werd van "geschikte" personen. Dit pleidooi had iets paradoxals, aan de ene kant een verstrakking van de interpretatie en aan de andere kant een verruiming. De aannemers zélf waren niet enthousiast over dit laatste punt, immers, eenmal gepasseerd zijnde ("niet geschikt") hield dit een negatieve kwalifikatie in die buitengewoon schadelijk was. Men ervoer dat als een veroordeling. Ook architekten hadden hun bezwaren: het passeren van de laagste inschrijver zoul immers kunnen berusten op "afipraken" met de betrokken architekt, wa armee de vertrouwenspositie van deze ith het geding kwam. Nieuwenhuis was in de verdediging van zijn voorstel niet erg konsekwent. Immers, hij betoogde dat de, ook in thet begin van de 19 e eeuw bestaande rechtsongelijkheid ( $\mathrm{z}$ ie hoofdstuk I.2.4) gekompenseerd werd door morele overwegingen, maar dat het latere verval van moraliteit die kompensatie teniet deed, wardoor de formele rechtsongelijkheid in en materiële verkeerde. Toen ontstond er kritiek vanujt een gebrek aan moraliteit "afspraken" a annemer - architekt) trachtte hij die te pareren met morele principes (een goed architekt deed zoiets niet). Hij, Nieuwenhuls, bepleitte voorts het installeren van een register van goede aannemera (met conduite stat), met daraan verbonden een recht van beroep bij onjuist wardeoordeel. Hij was tegen de instelling van een aannemersvakdiploma. 
Een teer punt was voorts de feitelijke levering van bouwmaterialen. Par. 463 legde de verplichting op de aannemer om "bestek en tekeningen te vergelijken, maten te kontrôleren, het ontbrekende bij te leveren en bij onvoldoende beschrijuing zoodanig te verrichten, als de aard van het werk zulks vereischt". Een afschuifsysteem in optima forma:

Zelfs vond men de zinsnede dat de directie slechts over "theoretische" kundigheden beschikt (* 45). Deze stelling werd nog versterkt door uitweidingen over de praktishe kundigheden van de aannemer en de theoretische van "de directie" als bereider van de bestedingsstukken. Met de praktische kennis van de directie was het kennelijk niet best gesteld. Zo signaleert Nieuwenhuis een totaal

ontbreken van "de berekenar van de financiële zijde van een plan, de bestekmaker en uitbesteder" als zelfstandige funktie, terwijl deze juist de brug moest slaan tussen ontwerper en uitvoerder.

De kwintessens van het geheel is duidelijk: de architekt ziet zich primair als ontwerper zonder veel technische en administratieve kennis, en de daaruit voortvoelende problemen worden afgeschoven op een rechteloze aannemer. Dat Nieuwenhuis de moed opbracht als koploper voor zijn vakgenoten te fungeren siert hem bovenmate. Dat zijn indringend betoog vrijwel geen weerstand ondervond bij zijn kollega's bewijst zijn gelijk, al hebben zij de gewraakte overheidsbepalingen veelal onverkort in hun bestekken opgenomen.

III. 4.4

de rechtsverhouding opdrachtgever - aannemer nader overwogen

De lezing van Nieuwenhuis bleef niet zonder gevolgen. Het bestuur van de sociëteit "De Nijverheid" gaf haar in 1885 in druk uit en verspreidde har als brochure (* 46).

De Amsterdamse Aannemersvereniging voegae deze brochure toe aan een adres aan de Kamer van Koophandel en Fabrieken te Amsterdam dd. 01-02-1886. Tevens werd een wijziging beplelt van 1933 BW en 1938 BW (vervallen bij van 22-06-1923) in relatie met 1645 BW en 1646 BW in verband met de aansprakelijkheid voor schade van de aannemer.

"Voor fouten en onvolledigheden in plannen voorgeschreven materialen of gebruik daarvan, wanneer deze plannen niet door hemzelf zijn ingelevera" (punt A.2 van het adres)

Niet alleen de AAV zorgde voor rechtsongelijkheid. Ook in vele partikuliere bestekken van die tija komt men bepalingen tegen die de directie rechten verschaften van een bijna ongeloofwardige onbeschamaheid (* 47). 
Mar de roep om rechtvaardigheid kreeg gehoor, $z i j$ het eerst zes jaar later. In 1890 wordt namelijk van regeringswege en kommissie ingesteld tot herziening ran de AAV 1882. Ook een jurist mengde $z i c h$ in het koor van protesterenden, mr. E.J.C. Goseling advocaat en procureur te Amsterdam. Zijn beschouwing (*48) sluit in hoofdlijnen aan bij Nieuwenhuis" betoog.

Hij bepleit:

1 een geschillenbeslechting door drie scheidsmannen, samengesteld volgens de $1+\mathbb{1}=3$ methode, die een bindende uitapraak doen

2 een verbetering van de beschrijving van het werk in het bestek, zodat de architekt niet langer "kan maken wat hij"wil", op grond van vage omschrijuingen

In een redaktioneel artikel neemt H.G. Jansen (* 49) selling tegenover Goseling voor wat betreft het eerste punt op grond van de grotere kennis van de dicectie met betrekking tot de "technische voorschriften" van deze ten opzichte van de aannemer. Waarschijnlijk bedoelt hij darmee dat, "de direktie" voldoende know-how bezit om een geschil te beoordelen. Hij gaat daarbij voorbij aan het feit dat "de direktie" altijd partij is in een geschil met de aannemer: of vreesde hij een afbrak van zijn

autoriteit? Met Goseling "s tweede punt kon hij zich echter geheel verenigen. De onwetendheid van de opdrachtgever als kontraktpartij bepalde de positie van de architekt als direktievoerder immers tot die van rechter in plats van die van tot partij.

De regeringskommissie kweet $z i c h$ van haar taak hetgeen in 1892 tot een wijziging van de AAV 1882 leidde.

III. 4.5

de Raad van Arbitrage ingesteld

Een flinke stap in de goede richting werd gezet in 1907 met de instelling van de Raad van Arbitrage voor de Bouwbedrijven in Nederland ( 26 ). Deze was samengesteld uit een voorzitter, een jurist/secretaris en 24 leden, gelijkelijk verdeeld over ingenieurs/architekten, de Matschappij tot Bevordering der Bouwkunst en de Nederlandsche Aannemersbond te Ansterdam.

Bij geschilien benoemden partijen drie scheidslieden uit de leden van de Raad. Bij ontbreken van konsensus over een of meer scheidslieden werd geloot ten overstaan van de voorzitter, desgewenst in het bijzijn van partijen. Toch is deze stap voorwarts nog een wankele. Het kwam in feite neer op een a nbeveling om de navolgende bepaling in de bestekken op te nemen:

"Alle geschillen, (ook die welke slechts door eene der partijjen als zoodanig worden beschouwd), welke naar aanleiding van de onderwerpelijke overeenkomst van aanbesteding en a anneming of van die, welke daarvan 
het uitvloeisel mochten zijn, tusschen den aanbesteder of de namens hem met de leiding en het toezlcht belaste personen (Directie) en den aamemer mochten ontstaan, zullen alleen en uitsluitend worden onderworpen an het oordeel van een scheidsgerecht, gekozen uit den Raad van Arbitrage voor de Bouwbedrijven in Nederland, overeenkomstig de bepalingen der statuten van genoemden Raad.

Aanbesteder en aannemer doen mitsdien afstand van hun recht tot het inroepen der tusschenkomst van den gewonen rechter, die bij gebreke van deze overeenkomst geroepen zoude zijn over een tusschen hen gerezen geschil uitspraak te doen en beperken die tusschenkomst alleen tot die gevallen, welke de Raad niet voor behandeling vatbaar acht.

Gedurende de voorbereidende matregelen tot benoeming van het scheidsgerecht van den Raad en verdex

gedurende de behandeling van het geschil, zullen de werkzaamheden inmiddels door den annemer worden voortgezet, bij gebreke warvan darin door of vanwege den anbesteder voor rekening van den aannemer wordt voorzien, behoudens de verrekening welke eventueel het gevolg zal zijn van de beslissing van het scheidsgerecht.

Alle kosten ontstaan uit de arbitrage komen ten laste van de partij of van de partijen welke daarvoor door het scheidsgerecht wordt of worden aangewezen. Partijen verklaren zich aan de beslissing van het scheidsgerecht te onderwerpen als aan een gerechtelijk gewijsde, uitdrukkelijk afstand doende van elk rechtsmiddel, hetwelk anders tegen die beslisging zoude kunnen worden aanglewend.

Alle kosten zullen, wanneer deze niet binnen 4 weken na de uitspraak van het scheidsgerecht zijn voldaan, direct in rechten opvorderbaar zijn, als eene schuld welke bij onderteekening van het bestek wettelijk wordt erkend te bestaan."

Naast de vrijblijvendheid omtrent het al of niet opnemen in het bestek van de geschillenclausule, heeft deze in zichzelf ook nog ontsnappingsmogelijkheden. De a anbesteder kon niet in aanmerking komende geschillen aitarukkelijk vermelden, terwijl de Raad zelf geschillen niet voor behandeling vatbar kon achten, zonder dat daramtrent duidelijk omschreven richtijnen waren gegeven.

Met de instelling van de Raad van Arbitrage kwam in principe een einde aan de personele unie van kontraktparti en scheidsman in de figuur van "de Direktie" . Sommigen zagen darin een degradatie van de positie van de architekt als boven de partigen staande deskundige. Aan de andere kant werd de architektenstand ontlast van het dilemma van 1646 BW terzake van het slechts schriftelijk mogen opdragen van meerwerk en de darmee gepaard gaande betalingsperikelen, vooral in die gevalilen warin meerwerk móst worden opgedragen (spoedeisende gevallen). 
Bovendilen was er eindelijk een instantie van beroep voor de a annemer tegenover de chicanerende opdrachtgever bij goedgekeurde mat niet-betaalde betalingscertifikaten (zie ook hoofdgtuk III.3). Arbitrage werd echter pas met de ontwerp-AAV 1911 bindend voorgeschreven (zie hoofdstuk III.4)

Prof. ir. Chr.K. Visger stelde in zijn al eerder aangehalde inaugurale rede op 08-10-1915 dat de geachillenbeslechting teveel in bestedershanden was geraakt, zoals bekend valk met uitsluiting van de rechter. In 1907 nog werd de eindbeslissing voor een gemeentelijke besteding nog steeds bij $B$ \& gelegd, zonder recht van beroep. In de AAV van 1892 voorzag men in slechts vier gevallen warin arbitrage was toegestaan, in 1898 werden het er zes (a $t / m$ f par. 495 AAV 1901). Of er sprake was van de gekwalificeerde 6 gevallen werd op zilch een punt van strijd, waarbij het laatste woord vaak aan de rechter werd gelaten.

Na de totstandkoming van de ontwerp-AAV 1911 werd voorzien in integrale arbitrage zodra een geschil door één der partijen als zodanig werd gezien. Vaak echter werd deze clausule blj bestek ontkracht. Uiteindelijk verbood de Nederlandsche Aannemers Bond de inschrijuing van haar leden bij a anbestedingen onder andere voorwarden dan de genoemde.

Visser vermeldt nog een één-partijen-bepaling (Bestuur van een Coöperatie) bill een besteding op 3 augustus 1915 te Hoogland mar dan behoort dit reeds tot de uitzonderingen. "Richt zoals gij zelf gericht, handelt zoals gij zelf behandeld zoudt willen worden", was zijn devies.

De rol die de partikuliere architekt als man-tussen-tweevuren in deze ontwikkeling heeft gespeeld is niet te achterhalen. Hij kon immers een moeizaam bevochten verbeterde rechtspositie van de aannemer geheel teniet doen via het bestek. Hoewel het ongetwijfeld zo geweest zal zijn dat uit puur kommerciële motieven sommige architekten hiervoor niet zullen zijn teruggeschrokken, is het heel onaannemelijk dat de bonafiden zich daartoe zouden hebben geleend, gezien de baanbrekende rol die hun vakorganisatie, de $B N A / M i j$. TBB, in de totstandkoming van zuiverder verhoudingen heeft gespeeld.

Dat de arbitrage geen onbesproken instelling was blijkt uft de diskussie in 1929. Aanleiding was de beslissing van de aannemersbonden om met ingang van 10-01-1929 niet meer in te schrijven op werken met een bestek zonder arbitraal beding. De verontwardiging was groot. Het $\mathbb{R} i j k$, negen provincies, en vele gemeenten w.o. Rotterdam, Den Haag en Utrecht aanvardden dit niet. Niet, zoals Rosenboom stelt, uit liefde voor de overheidsrechter mar uit wantrouwen jegens het arbitrage-instituut. 
Hij bepleitte dan ook een heroriètatie (*50), nodig vanwege veronderstelde subjektiviteit van de voorzitter bij de mondelinge behandeling en vermoede inkompetentie in het onderscheid van hoofd- en bijzaken. Ook de kwalifikatie "goede mannen naar billijkheid." wordt meer als "goedig" opgevat ten nadele van de aanbesteder.

Het voorbijgaan aan nadrukkelijk overeengekomen bepalingen wekte bevreemding ondat hiermee niet de interpretatie van de overeenkomst in het geding is, mar de overeenkomst zêlf. De onpartijdigheid scheen inderdaad ver te zoeken. Rosenboom bepleitte derhalve elke relatie van de arbiters met "partijen" qua professie, te vermijden door

samenstelling van de colleges uit twee vakmensen en eén jurist als voorzitter en ook het instellen van een hoger beroepmogelijkheid. Hij vroeg de BNA om toetsing van het instituut. Prof. Diehl is het hiermee niet eens (* 51). De afkeer van deze vorm van arbitrage kan bij de overheid niet zo groot zijn, omdat gelijksoortige wijze van beslechting van andersoortige geschilien well werd erkend. Hij verweet Rosenboom een slordige redeneertrant door alle arbitrages over efn kam te scheren, zonder deze juist te definiëren. slechts via een omweg viel te ontdekken dat de Raad van Arbitrage voor de Bouwbedrijven in Nederland werd bedoeld. Diehl achtte het voldoende als er een grotere plats werd ingeruimd voor de juristen, en achtte een aanval op de integriteit van de voorzitter overtrokken.

Bovendien waren er genoeg juristen ter zitting aanwezig om een afdwalende diskussie terug te brengen op het goede pad. objektiviteit was niet per definitie voorbehouden aan juristen. Voor hoger beroepmogelijkheid voelde Diehl wel, matr verlangde wel een duidelijker motivering, wijzend op het feit dat hoger beroepprocedures in het algemeen termijn-verlengend werken. Het BNA-Bestuur onderschreef Diehl's betoog.

Ook mr. Ph.J. van Vliet keerde zich tegen Rosenboom's aanval op het instituut: dat vele gemeenten en provincies hun standpunt nog niet hadden bepald kwam zijns insziens door de afwachtende houding ten opzichte van "waterstat". Bovendien had de Vereniging Nederlandsche Gemeenten reeds maanden geleden aan de a annemersbonden een konceptarbitrageregeling toegezonden ter beoordeling. Ook 's ministers aarzeling bleef niet gestoeld op wantrouwen jegens arbitrage. Slechts een "algemeene toepassing" ontmoette bij hem "eenig bezwar". Voorliefde voor de overheidsrechter kan dat niet $z i j n$, want de AV waterstaat sloot die uit en legde de eindbeslissing bij de Minister neer. Bovendien had ook de in 1920 ingestelde statcommissie arbitrage zonder ontbindende voorwarden a anbevolen in has raport.

Van vilet duidde erop dat scheidslieden zelf hun werkwijze konden bepalen in tegensteling tot de beroepsrechter. Daardoor zou hun werkwijze in de ogen van juristen vaak bemoeizuchtig, ongeduldig en voorbarig overkomen, zeker in 
vergelijking met de atrikt gereglementeerde gang van zaken in de rechtozal. Een tekort schieten in bouwkundige kennis van een juriet-voorzitter behoorde voorts tot de warschijnlijkheden. Hij ondersteunde Rosenboom's pleidooi echter woor benoeming van een heel scheidsgerecht door een autoriteit buiten partijen om.

Het hoger beroep zou in zijn ogen Rosenbooms bezwaren niet wegnemen, zeker niet war de op te lossen geschilien meestal geen rechtskwesties betreffen die voor tweeerlei ulteg vatbaar zijn. Mede door de langere procesduur zouden de nadelen van dit hoger beroep groter zijn dan de voordelen.

op 17 september 1930 werd door de Vereeniging van Delftsche Ingenieurs, de Matschappij BNA en NAB een studiekommissie ingesteld ter beantwoording van een aantal gerezen vragen (*52):

1 de wenselijkheld van hoger beroep bij arbitrage voor - herstel van fouten bij eerste uitspraak

- meerdere bevrediging van het rechtsgevoel

- bevordering van de eenheid in de rechtspraak

- sneller herstel van onjuiste uitspraak, dan door tussenkomst van de rechter

- nieuwe argumentatie mogelijk

- zorgvuldiger behandeling in eerste aanleg

tegen - de langere duur van de geschillen

- hogere kosten procedures

- voortduren van verstoorde verhoudingen tussen partijen

- de tweede instantie is moeilijk goed te regelen

- bevordering van inhouden van betalingen, aldus een dwangmiddel vormend voor de zwakste partij

- er ontstaan teveel instanties, immers ná hoger beroep blijft beroep op de rechter open tot a an de Hoge Raad

2 is het wenselijk een bijzondere regeling te maken voor spoedarbitrages?

$\mathbb{E}$ beatonden bij de nieuwe AV waterstat 1930 nader gedefinieerae mogelijkheden van spoedarbitrages voor bijzondere gevallen als: afkeuring van bouwstofien of werk, woor directie-uitspraken op grond van clausule "ten genoege van de directie.." "wijze van uitvoering etc. De Commisaie is niet geporteerd voor bijzondere regelingen anders dan de huidige gezien de procedureverlengende faktoren maar bepleit stroomlijning van het huidige systeem.

3 is het mogelijk en wenselijk orn de $3 e$ afdeling van de Av waterstat 1930 ook van toepassing te verklaren woor provincies, gemeenten en waterschappen?

De Commissie zag zich door tijdgebrek genoopt om zich te beperken tot artikel 10 van deze afdeling 
In de nieuwe AV Waterstat 1930 werd de mogelijkheid geopend om door middel van een procesverbaal de toestand, welke tot het geschil aanleiding gaf, vast te leggen. Die bevoegdheid ontbrak partijen tot dusver ten ongerieve van de Commissie van Advies welke in eerste anleg over het geschil had te oordelen. Onduidelijkheid bleef wat er gebeurde als ển der partijen medewerking weigerde. In de nieuwe AV Waterstaat 1930 werd een "hoofd van dienst" geintroduceerd ter beslechting wan geschillen zowel voorlopig als definitief. Een dergelijk, hoger, ambtelijk echelon zou naar de mening van de commissie bij andere publiekrechtelijke lichamen niet gerealiseerd kunnen worden.

Met de invoering van de nieuwe AV Waterstat 1930 zou de samenstelling van de Commisise van Advies bestaan uit drie leden: één aangewezen door de Minister, éen door de aannemer in overleg, een derde en liefst een jurist als voorzitter, partij-arbitrage dus. De Studiecommissie wees voor hat kritiek op dit systeem naar het maandblad "Arbitrale Rechtspraak" ( * 53), de kritiek van $\mathrm{mr}$. W. Nolen $(* 54)$ die het principieel fout achtte een arbitraal college aldus samen te stellen, terwijl ook de Algemene Rekenkamer (* 55) zich in krachtige termen tegen partij-arbitrage keerde. De studiecommissie had voorts bezwaren tegen de verplichting om de jurist tot voorzitter te benoemen, omdat deze de usances van het vak niet kende en de vakkennis niet bezat om het geschil technisch te kunnen beoordelen. Een rechtsgeleerd secretaris, zoals de meeste arbitragecommissies die kennen, achtte men een betere oplossing.

is het wenselijk de herkiesbaarheid van de leden van de Rad van Arbitrage voor de Bouwbedrijven in Nederland an bepalde voorwarden of an tijdsduur te binden?

De enige voorwarde voor verlenging van het 1 idmatschap van het college, dat statutair 4 jaar durde, was het niet-effektueren van het vetorecht van de andere constituerende verenigingen. De Studiecommissie zag geen noodzaak voor verandering hoewel. ter vermijaing van pijnlijke situaties de zittingsduur zou moeten worden beperkt tot $2 \times 4$ jaar. De studiecommissie achtte voorts een geschikte arbiter hoofdzak en dus voorwaarden en tijdsduurbeperkingen ten aanzien van het lidmatschap van het college onnodig in het huidige systeem. Het stellen van een leeftijagrens kon, bij nilet-adekwat funktioneren, een ongewenste verlenging uit humanitaire overwegingen voorkomen. De studiecommissie beantwoordde de haar gestelde vraag dan ook ontkennend. 
is het gewent de mogelijkheid te scheppen voor

*atlegging bestaande toestand (*62)?

(Analoog an art. 219 Rv jo art. 876 Rv)

In de Av Hateratat 1930 werd geen oplossing gegeven voor niet-medewerken an de vastlegging door fen der partijen. Mogelifk zou zijn daarvoor een remplacant te kiezen uit de leden van de Rva via de voorzitter. voor het oplobsen van kleine geschillen zou de voorzitter dxie leden kunnen aanijzen.

In 1932 beval het bestuur van de RAB bestekteksten a an terzake van geschillen overeenkomend net AV waterstat 1930 (*56) t. w.

1 definitiegeachil

2 oordeelgrond (als goede mannen naar billijkheid)

3 kostenverdeling over partijen inzake het geschil

4 getn stilegging van werkzaamheden gedurende het geschil

5 onkosten tengevollge van oponthoud in de scheidsrechterlijke uitsprak zijn voor de in "t ongelijk gestelde partij

6 uitspraak is bindend, ook voor wat betreft de kosten

7 eiser kan ten alle tijae de tussenkomst van de Raad inroepen tex verkrijging van een executoriale titel

8 drie maanden na besilising aanbesteder omtrent elndafrekening, volgt niet-ontvankelijk verklaring

9 bij nietigheid of niet-bindend zijn, bij rechterlijk gewijgde, van het gehele of gedeeltelijke vonnis heeft elke partij het recht het geschil, voorzover niet beslist, opnieuw an het oordeel van de Raad te onderwerpen, mits binnen drie manden na het in kracht van gewijsde gaan van de scheidarechterlijke uitspraak.

III. 4.6

nieuwe bedreiging voor de aannemer: hulp aan derden

Bedreiging voor het aannemersbedrijf kwam ook nog uit een andece hoek: de technische ontwikkelingen op het gebied van de installaties. Men hanteerde zoals gezegd het system van "entreprise generale" hetgeen inhield dat de a annemer het werk voor het bouwkundig deel total annam, dus inclusief "hulp aan derden". Maar steeds meer installaties kwamen uit buitsland van waruit ingenieurs-

bureaus de nederlandse architekten "bewerkten" met geavanceerde systemen. Nar blijkt *57) schortte er aan de tekeningenvergtrekking alles als de opdracht eenmal binnen was, zodat de financiele risico's voor de aannemer onarvarabar hoog opliepen. Ondat een 100-jarige praktijk zich niet zo snel ilet a anpassen, namen de a annemers zelf het initiatief in handen. In een circulaire gericht aan de architekten gaf het hoofdbestur van De Nederlandsche Aannerarsbond (NAB) te kennen dat 
"na 1 juli 1908 geen hulp van welken aard ook zal worden verleend bij het aanleggen van verlichting, verwarming en dergelijke, en dat ook niet meer voor rekening van den aannemer zal worden genomen de herstelingen van beschadigingen welke bij het aanleggen ontstaan, dan tegen terugbetaling van de daarop vallende kosten".

Niet alle architekten hanteerden overigens deze door de NAB voorgestelde besteksbepaling, in zijn geheel, mar de meeste wel.

of de "boycot" veel heeft uitgehald valt te betwijfelen; niet alle a annemers waren 1 id van de Bond.

Deze bundeling van krachten van beroepsgroepen was nieuw, en makte snel furore.

In architektenkringen begon men zelfs te klagen over het verschijnsel van trust- en kartelvorming bij de annemerij. ook de aannemers zélf kregen daar op hun beurt mee te maken: Bonden van fabrikanten en leveranciers dikteerden hun voorwarden voor levering en prijsvorming. Het

"verenigt u" is de leus des tijds.

Sommigen zagen de situatie somber in en waren bevreesd dat de strijd tussen de machtsblokken uiteindelijk alle partijen zou kunnen schaden. De aanhaling van potgieters dichtregels in de vaklitteratur is veelzeggend:

"Worstling kenmerkt onze tijd,

Heb er oog voor, allerwege

slechts wie deel nam aan de strijd

Smakt de vruchten van de zege."

I I I. $4 \cdot 7$

de besteksbepalingen van de architekt en het boetebeding rond 1900

Mr. J.P. Bruynzeel neemt in 1911 het boetebeding onder de loep (* 58 ). In relatie met 1340 BW gat hij na of bij overschrijding van de opleveringsatum in-gebreke-steling verplicht is. Kernpunt daarbij is of boetebepalingen van poenale aard zijn of een korting als zakelijke transaktie. bij voorbaat; dus als strafsanctie (wartoe aanbeateder niet bevoegd was) of als uitoefening van het retentierecht, hetgeen wettelijk was toegestaan.

Vonnissen van de Rechtbank Amsterdam en Rotterdam achtten in-gebreke-stelling niet nodig. Rechtbank Tiel konkludeerde evenzo omdat de bedoeling van het beding zou zijn dat "met het verloop van den dag de schuldenar in gebreke zal zijn.

Het Hof Amsterdam (* 59) achtte in-gebreke-stelling wel vereist en vernietigde het vonnis van de Rechtbank Amsterdam. Het Hof ziet het beding als van poenale ard als 
platsvervanging voor de opgetreden schade. Daarom kan atraf eerst worden gevorderd na voorafgaande in-gebrekestelling. Ook de Rechtbank Rotterdam heeft dit standpunt toentertija enkele malen gehuldigd. Het verstrijken van de overeengekomen termijn-op-zich was derhalve geen motief voor het hanteren van de boeteclausule.

Als sentiele voorwarden voor de uitvoering van

boetebedingen stelt Bruynzel twee zaken:

- Bchade bij de a anbestedex

- toerekenbarirheid bij de aannemer

Rond 1850 verwekte reeds de bestekterm "dagen" in plats wan werkdagen diakussie met betrekking tot het boetebeding en overschrijding van de kontrakttermijn. ook daarbij ging het om of schadevergoeding of strafsanctie. In het laatste geval oordeelt de Hoge Raad in 1851 dat bedingen van een aard nimmer door uitlegging worden geèxtendeerd" (* 60). De Arrondissementsechtbank Breda ging hier een jaar later aan voorbij en liet de letterlijke bestektekst prevaleren (* 61). De latste mening was ook de Rechtbank Rotterdam (* 62) toegedaan en wel op grond van par. 478 AAV. Men konkludeerde echter dat niet-toerekenbaarheid de aannemer vrijwarde. Men bedenke hierbij steeds dat het begrip "werkbare dagen" als kontrakttermijn volstrekt éenzijdig kon worden geinterpreteerd. Als voorbeeld diene het volgende:

"par. 28 .

Oplevering, onderhoud, korting en ingebrulkneming van het gebouw.

Onmiddellijk na de gunning van het werk zal de aannemer met de uitvoering van de in het bestek omschreven werkzamheden moeten aanvangen en met zoodanigen spoed voortzetten, dat op 1 april 1915 het werk geheel gereed is en het gebouw in gebruik kan genomer worden.

Na deze oplevering behoudt de Aannemer alle voorgeschreven werken, niets uitgezonderd, nog zes manden in onderhoud. Algemeene werkstakingen, georganiseera door vakvereenigingen zullen worden beschouw als force-majeure.

Vertraging tengevolge van orders vanwege den

Aanbesteder, strenge vorst wolgens getuigenis van de Directie, doen de opleveringsdata opschuiven met een zelfde aantal dagen als en zoodanig oponthoud heeft geduurd: regen- en vorstagen worden niet in mindering gebracht.

Overigens verbeurt de Aannemer voor elken dag te late oplevering wan den hier gestelden termijn van oplevering, eene som van twintig gulden van den eerstuolgenden betalingstermijn in te houden; dezelfide som verbeurt ook de Aannemer, wanneer hij nalatig is in het nakomen van de in dit bestek vervatte bepalingen of naar aanleiding daarvan door de Directie gegeven bevelen; na driemal op zijn verzuim te zijn gewezen, in welk geval de korting op den 
eerstvolgenden termijn wan betaling zal plats hebben, welke korting opnieuw zal worden ingehouden, indien hij drie dagen na de latste anmaning nog geen gevolg heeft gegeven aan de hern gegeven opdracht.

voorts wordt er nog op gewezen, dat or verzuim of overtreding van de besteksbepalingen, dit werk

betreffende, te constateeren, of om den Aannemer in tijd van verzuim te stelien, geen rechtsvordering of sommatie hoegenaamd noodig is, mar eene eenvoudige verklaring van den opzichter bij afwezigheid van den Architect voldoende zal zijn."

(uit de besteksbepalingen voor de bouw van het kantoor van de Levensverz. Mij. "De Nederlanden" te Amsterdam 1914).

Een strijdpunt is vaak geweest de wraag of een werk als opgeleverd en aanvara beschouwd moest worden. Of de architekt het werk had goedgekeurd was daarbij vaak van geen enkel belang. Niet alleen bij kwesties rond oplevering maar ook ten aanzien van de verrekening van meerwerk werd met de rol van de architekt als direktievoerder valk weinig rekening gehouden. Maar al te vaak kwam het voor dat de architekt meerwerkrekeningen van de a annemer goedkeurde, mar dat de betaling daarvan door de opdrachtgever uitbleef, omdat deze zich beriep op $1646 \mathrm{BW}$. Het ging daarbij dus om de bevoegdheid van de architekt om op te treden als vertegenwoordiger van de principaal.

Bruynzeel signaleert in 1910 dat de diskussie over het al of niet van openbare orde $z i j n$ van $1646 \mathrm{BW}$, de essentiele vraag, nog volop aan de gang is, mat dat het ontbreken van een schriftelijke opdracht betaling van meerwerk niet in de weg stond, mits de opdracht daartoe op enigerlei wijze door de tegenpartij was erkend. Het oordeel van de rechter was niet eensluidend. Hof Amsterdam (*63) niet van openbare orde, Rechtbank Rotterdam (*64) wel.

II I. 4.8

de koncept-AAV 1911 van architekten, ingenieurs en aannemers

In 1911 komt een koncept tot stand tot wijziging van de AAV door een "Commissie van Afgevaardigden" van de vereniging van Delftsche Ingenieurs, de Maatschappij tot Bevordering der Bouwkunst en Nederlandsche Aannemersbond (*65). Naast verbeteringen, ook in de rechtspositie van de annemer (aansprakelijkheid) blijft echter de borgtocht bestaan, ondanks alle kritiek, zij het dat zij beperkt wordt tot een zakelijke. Het argument daartoe is de startpositie van de jonge aannemer te vergemakkelijken.

De opkomst van het socialiame werkte de werkstaking in de hand, wat daarmee tot een groot financieel risiko van de aannemer werd. Deze calamiteit is in het koncept AAV als óvermacht gekarakteriseerd $(* 66)$. Het Bestuur der SociaalTechnische Vereeniging van Ingenieurs en Architecten 
Het als owermacht a nmerken zagen zij als een verzwaring van de positie der werknemers op het bouwwerk, vanwege het daarmee verbonden recht op termijnverlenging, zodat de geldelijke nadelen wrijwel geheel ten laste kwamen van het werkwolk. Zij vonden dat arbitrage moest uitwijzen of de aanemer an het konflikt schuldig was, of niet. In het eerate geval kon geen sprake zijn van overmacht.

Voor de boordeling van het genoemde commisie-voorstel (* 67) liet de Matschappij een pre-advies opstellen door de Comissie ter Behartiging van de Belangen van de Architect" onder voorzitterschap van C.B. Posithumus Meyes $(* 68)$.

III. 5

De a nnemer als opdrachtgever van de architekt

De stormachtige stedebouwkundige ontwikkeling in de jaren 20 on het bestaan van een vooruitstrevende dienst stadsontwikkeling in de gemeente Amsterdam deed merkwardige verhoudingen ontstaan tussen architekten en a annemerij. De stedebouwkundige schema's dienden, naar gemeentelijk inzicht, ingevuld te worden door architekten terwijl de realisering van de woningbouwprojekten een eigenbouwers a angelegenheid was.

Hieruit onstond de veel gewrakte "schortjesarchitecturu" . De afgedwongen samenwerking zorgde wel voor een synthese tussen stedebouwkundig plan en stratwanden zoals die in de uitbreidingeplannen waren vastgelegd, maar veroorzaakte tevens een breukviak tussen architekt en a annemer door de "overbemeting" van de architektenrol. Voor de "invulling" van de straatwanden door de elgen bouwer was deze verplicht gebruik te maken van de diensten van een architekt.Het politieke klimat stond niet toe dat de gemeente de eigenbouwers kon dwingen tot het inschakelen van de architekt voor de gehele planfase, en anderzijas wilden de a annemers zo gauw mogelijk van de architekten af. Deze gang van zaken werd nog versterkt door het gaandeweg inkrimpen van de gesubsidieerde woningbouw door de gemeente. De eigenbouw vertegenwoordigde $85 \%$ van alle bouw in de nieuwe stadsdelen. Er schijnt zelfs sprake geweest te zijn van een architektenstaking (*69). De meest dwaze situaties deden zich inderdaad voor omdat soms elke relatie tussen plattegrond en gevel ontbrak.

De architekten waren inventief in het bedenken van aplosingen. Eén van de voorstellen betrof de oprichting van een bouwmatschappij als synthese van financien, architektuur en uivoering. De architekt als medeondernemer, architekt-bouwer. De architekt Gratama werkte mee aan de Bouwmatschappij HAGA maar de zaak liep binnen de BNA $z \delta$ hoog op dat Gratama, om lid te kunnen blijven, zich moest "verlagen" tot adviseur/architekt. 
Toch waren zijn bedoelingen onverdacht. zijn idealisme om de eigenbouw ut de kwade reuk te halen deed hem pleiten voor participatie van de architekt als gelijke van financier en bouber. De of - side opstelling van de architekt, voortuloeiend uit diens onafharkelijke positie, berokkende nar zijn inzicht grote schade aan de (eigen) bouwkunst. Toch attendeert architekt Blaauw, ter verdediging van het BNA-standpunt, erop dat de vertrouwenspositie een geheel andere doelstelling is dan het bouwen van de ondernemer, die immers op winst uit is. Hij acht deze belangentegenstelling onoverbrugbaar, en bovendien de fam van de woningbouw te twijfelachtig ("een sterken stroom van ongerechtigheden") om daaraan de goede naam van het architektenberoep te verbinden. Bovendien beschikt de architekt niet over risikodragend kapitaal naar zi jn mening. Bezwerend wezen velen op een zekere vooruitgang: een achttal jaren terug kwam er toch immers aan de woningbouw helemal geen architekt te pas (Hulshoff)!

Architekt Van der Schaar (*70) signaleerde (1930) dat door de te overheersende rol van de architekt in de woningbouw de annemer tot kind van de rekening werd. Hij pleitte voor een terugdringen van de architekt en platst zich daarme tegenover Gratama, die immers zakelijk belang in de aannemer voorstond om integratie te bewerksteliigen. De bevoordeling van de architektenpositie achtte ook Van der Schaar onjuist.

Voor de honorering waren er twee "Tabellen" in omloop, die van de BNA en van "architect Lammers d.d. 06-11-1929" die op deze specifieke situatie waren ingesteld. Uitgaande van het feit dat de architekt uitsluitend de gevels met bijbehorende details ontwerpt trachtte van der schar tot een honorariumregeling te komen als synthese tussen de genoemae twee. Tevens bepleitte hij de tatstandkoming van regels betreffende de rechtsverhouding tussen architekt en aannemer, omdat de opdrachtverlening bf beruste op de wankele aanname van goede trouw bij de architekt $6 \mathrm{f}$ op een op te stellen kontrakt dat de verhoudingen regelt.

van der schar dacht daarbij een techtsverhouding te kunnen regelen via een honoreringsafsprak "per strekkende weter gevel of oppervlak per wonjing"; een al te simpele veronderstelling.

Architekt Blaaww (*71) gat wel in op het "bijzondere" van de situatie warbij de bouwondernemer en opdrachtgever en ultvoerder is, zij het meer in matschappelijke zin. Hij signaleert fouten als gevolg van de breuklijn tussen architektuur en techniek zowel architektonisch (vormwil) a.s technisch (slechte detaillering van goede architektuur). De schuldvraag is onoplosbaar vanwege het ontbreken van de definitie van juridische grenzen in het kontrakt, zo dat al aanwezig was. Dat er uberhaupt bij een schuldvraag werd stilgestaan is interessant. Blaauw konkludeerde dat deze $\mathbb{1} n$ elk geval niet bij de architekt lag, enerzijds omdat de detailiering niet des architekts 
Was, anderzijds omdat de adnnemer ondetailleerbare architektuur immers bij aanneming had aanvard. Bladuw wes erop dat de "halvering" wan het beroep tot problemen mbet leiden en zag dit dan ook als een ernstige tekortkoming. Hij betwijfelde de juistheid van het geuite werwijt van gebrek a an economisch inzicht bij de architekt, omdat er volgens hem geen definitie van dit begrip te geven zou zijn. De esthetiek makt immers een afbakening onmogelijk Esthetiek en economie war ligt de grens? 


\section{SAMENVATTING}

De periode van 1850-1940 is van groot belang voor de rechtspositionele aspekten van de drie hoofdrolspelers in het bouwproces. Het minst duidelijk is de positie van de opdrachtgever. Hoewel eigenlijk hoofdpersoon treedt deze, althans wat de "burgerbouw" betreft, slechts zelden op de voorgrond, en dan nog in negatieve zin; chicanerend en onmatschappelijk. Mede debet daaraan zal zijn het feit dat slechts konflikterende situaties via de jurisprudentie de literatuur bereiken. Voor Waterstaatswerken ligt de situatie anders. Het hechte bolwerk van de minister van Waterstat is als opdrachtgever niet gespeend van paternalisme en konservatief denken. In haar houding vindt men een stuk zelfbescherming terug tegen het ambachtelijk verval in het uitvoerend bouwbedrijf. Dit wantrouwen blijkt slechts met moeite in positieve zin te beinvloeden, hetgeen resulteert in een moeizaam bevochten reeks aanpassingen van de Algemene Administratieve Voorwarden wardoor tegen het eind van de periode gesproken kan worden van een redelijk evenwichtige situatie.

Het uitvoerend bouwbedrijf heeft zich, mede door de hulp van architekten en ingenieurs, in diezelfde tijd een redelijke rechtspositie kunnen verwerven. De toenemende organisatiegraad van de bouwbedrijven heeft daar veel toe bijgedragen al bleken machtsmiddelen als boycot en staking niet altijd even effektief. Belangrijk is de totstandkoming van het arbitrage-instituut dat zich al vrij snel, ook bij aanvankelijk weigerachtige overheden, een positie verwierf die het niet meer zou behoeven af te staan.

Tot slot de rechtspositie van de architekt. In het tijdvak van plm. 1880 tot 1932 ontwikkelen zich de standaardregelen die uiteindelijk tot ver in 1980 dienst zouden blijven doen. Vanuit een aanvankelijk aarzelend aanvaarde honorariumtabel via de daarbij behorende "toelichting" naar de Algemene Regelen voor de honorering van de Architect.

Vooral rond de eeuwisseling is de relatie opdrachtgeverarchitekt nogal tweeslachtig. Enerzijds deskundig radsman en verdediger à tort et à travers van niet altija even acceptabele opdrachtgeversbelangen, anderzijds voorvechter voor een rechtvaardiger behandeling van de aannemer. Darnaast figureert nog de architekt die boven alle materiële belemmeringen uitstijgt. De pluriformiteit van het verschijnsel architekt vindt uiteindelijk toch zijn weerslag in de rechtsverhouding die voor allen geldt.

Buitenkontraktueel gebeurt er in deze perilode niet bijzonder veel met de architekt; al is de uitbreiding van de Auteurswet tot de Bouwkunst (zie hoofdstuk VI) een feit van belang. Titel- en beroepsbescherming van de architekt 
komen mede door de aktiviteiten van de jurist Bruynzeel en de architekt Friedhoff, langzaam in de belangsteliing. Tot wettelijke regelen komt het echter nog niet. 
I De opmerker

2 Albert Louvet

3 De Opmerker

4 De opmerker

5 Bouwkundig We kblad

6 Bouwkundig weekblad

7 Bouwkundig Weekblad

8 Bouwkundig Weekblad

9 Bouwkundig Weekblad

10 Bouwkundig Weekblad

$11 \mathrm{Rb}$ Haarlem

12 Bouwkundig Weekblad

13 Bouwkundig Weekblad

14 Bouwkundig Weekblad

15 Bouwkundig Weekblad

16 Bouwkundig Weekblad

17 mr. D.E. van Lennep

18 mr. A.J.M. Hendrix

19 dr. W.A.M. Cremers

20 Hof Den Haag

21 Rb Almelo

22 Cremers/zonderland
Bouwkundig Weekblad Bouwkundig Weekblad Bouwkundig Weekblad

Bouwkundig Weekblad Bouwkundig Weekblad Bouwkundig Weekblad Bouwkundig Weekblad $\mathrm{Rb}$ Amsterdam $\mathrm{Rb}$ Rotterdam Hof Den Haag $\mathrm{Rb}$ Zierikzee $\mathrm{Rb}$ zierikzee Bouwkundig Weekblad Arbitrale Rechtspraak Bouwkundig Weekblad $\mathrm{HR}$

Arr. Rb Den Haag $\mathrm{HR}$
-1884 no. 12 blz. 101

- L'art d'architecture et la profession d'architecte Paris longedateerd, vermoedelijk +1900$)$

- $16-02-18.84$ blz. 58

- 08-03-1884 blz.85

- $1881 / 82$ blz. 125

- 09-05-1903 no. 19 blz. 193

- 14-05-1904 blz:231

- 21-05-1904

- 14-05-1904 blz. 231

- 15-11-1913 blz. 559-662

- 1913 niet gepubliceera

- 1915 no. 6

- 1919 blz. 303-308

-1922 blz. $282-289$

- 1938 blz. 130

- 06-02-1897 no. 6

- Civiel Rechtelijke Verantwoordelijkheid van Architecten en Ingenieurs 1889

- Het Recht en de Architect Tjeenk willink 1927

- Architecten en Aannemersrecht $v$. Mantgen en de Does Amsterdam 1926

- 26-11-1915 NJ 1916/745

- 25-02-1925 W11557 en Rb Groningen 09-05-1924 W11263

- Bouwrecht III (suppl.78) blz. 23

- 1897 blz. 244

- 1910 blz. 423

- 1904 art. 5 honarariumregeling $18-05-1904$

- 1911 blz. 396

- 1918 blz. 11

- 1912 blz. 346

- 1912 blz. 387

- 19-04-1901 W9185

- $16-12-1846$ RBIX/103

- 02-11-1908 W8789

- 28-04-1908 พ8950

- 06-12-1911 W9307

- 1921 blz. 143

- no. 56 (RAB)

- 1925, blz. 159 e.v.

- 31-01-1919 NJ 1919/161.

- 31-05-1921 (niet gepubliceerd)

- 23-11-1917 
III. 7

VERVOLG NOTENLIJST

41 Rb Amaterdam

- 20-12-1915 (nilet gepubliceerd)

42 Rb Den Haag

43 Bouwkundig Weekblad

- 0B-12-1914 (niet gepubliceerd)

44 AAV 1882

45 Bouwkundig Weekblad

- 1932 blz. 356 e.v.

- par. 444t/m 446, 453,457, $467,473,475$

-1884 b1z. 222

46 Bouwkundig Weekblad

$-1886 \mathrm{blz} .34$

- 1888 blz. 89

- 1890 blz. 385 e.v./401 e.v.

- 1890 blz. 402 e.v.

- 1929 blz. 18 e.v.

- 1929 blz. 42 e.v.

- 1931 blz. 231 e.v.

- 1931 nrs. 22 en 23

- Handleiding voor Arbiters $2 e$ aruk blz. 36 e.v.

55 Verslag alg. rekenkamer- $1924-25$ blz. 34

56 Bouwkundig Weekblad - 1932 blz. 44

De opmerker

- 1908 blz. 28 e.v.

58 Bouwkundig Weekblad

- 28-01-1911 blz. 42

Hof Amsterdam

$\mathrm{HR}$

- 18-06-1907 (nilet gepubliceerd)

- 18-04-1851 w1251/1

- 13-07-1852W1359/3

- 08-06-1906 (niet gepubliceerd)

Rb Breda

62 Rb Rotterdam

63 Hof Amsterdam

64 Rb Rotterdam

65 Bouwkundig Weekblad

66

67

68

69

70

A.AV

Bouwkundig Weekblad

Bouwkundig Weekblad

Bouwkundig Weekblad

Bouwkundig Weekblad

- 18-01-1907

- 09-04-1909

- 1911 blz. 437

- 1911 (koncept) blz. 23 pt. 6

- 1911 blz. 111 e.v.

- 1912 blz. 26 e.v.

- 1927 blz. 221 e.v.

- $1930 \mathrm{blz} .177 \mathrm{e} . \mathrm{v}$.

- 1930 blz. 182 e.v. 
DE ARCHITEKT IN HET MAATCHAPPELIJK KRACHTENSPEL 1945-1985

IV.I Het bouwekonomisch beeld tussen 1945 en 1985

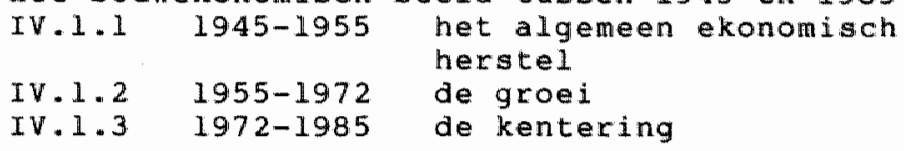

IV.2 De matschappelijke platsbepaling van de architekt in zijn verhouding tot de opdrachtgever

IV.2.I 1945-1955 de wederopbouw

IV.2.1.1 de architekt nog een

matschappelijk middelpunt?

IV.2.1.2 de diskussie rond de ontwerp-

architektenwet van 1949

IV.2.2 1955-1972 de hoogkonjunktuur

IV.2.3 1972-1985 de architekt in een

IV.2.4 het verschijnsel deel-

IV. 2.5 na 1985 opdrachten

IV.3 De opleiding tot architekt

IV. 4 samenvatting

IV. 5 Notenlijst 
DE ARCHITERT IN HET MAATSCHAPPELIJR KRACHTENSPEL $1945-1985$

IV.I

Het bouwekonomisch beeld tussen 1945 en 1985

IV. 1.1

1945 - 1955 het algemeen ekonomisch herstel

Het algemeen ekonomisch herstel van Nederland na 1945 heeft zich in vrij snel tempo voltrokken, in aanmerking genomen dat er toch grote schade was angericht. Het totale vermogensverlies bedroeg 318. De kultuurgrond was voor $12,5 \%$ onbruikbaar, het scheepsbezit was nog maar voor 48 \% intakt en de totale spoorweglengte voor 62 vernield (* 1$)$. De start van dit herstel verliep echter vrij traag; pas nadat de infrastruktuur en de energievoorziening waren hersteld kon ex van een redelijk ontwikkelingstempo sprake zijn.

De werkgelegenheid werd hierdoor gunstig beinvioed, zeker ten opzichte van de voorloorlogse periode. Tussen 1921 en 1939 was 1936 een dieptepunt met 14 , 8 van de beroepsbevolking als werkloos. Tussen 1945 en 1955 scoort 1952 het hoogst met slechts $3,4 \%$.

In deze tien jaren zet zich een verschuiving in in de samenstelling van de beroepsbevolking. De ontwikkeling van de industriele aktiviteit neemt een deel van de werkenden in de landbouw op, die wrijkomen als gevolg van de mechanisatie. Bovendien ontketent de industriele expansie een explosieve groei van de dienstensektar.

Howel een zodanige ontwikkeling een positieve invloed zou moeten hebben op het bouwen was dat maar zeer ten dele het geval, gezien de vrees voor een overspanning van thet ekonomisch evenwicht enerzijds en een herhaling van de grote bouwwerkloosheid van voor de oorlog anderzijds. Immers, in 1936 bedroeg die werkloosheid 47,78 . De bouwmarkt werd dacrom door de regering streng gekontroleerd. Een te snelle groei van de bouwnjuerheid zou vanuit het werkgelegenheids-oogpunt een gevaar opleveren van arbeidsoverschotten na de inhalmanoevre. Een stelsel van rijksgoedkeuringen remde darom een te snelle ontwikkeling in de bouw. Juist ondat de volkshuisvesting meer politiek bepald was dan de utiliteitsbouw, althans waar het gesubsidieerde woningbouw betreft, makkte dat de definitie van de kwantitatieve woningbehoefte per jaar niet gemakkelijker. Daaraan gekoppeld is uiteraard de onzekerheid over de ontwikkeling van die woningbehoefte. Rond 1950 werd deze gesteld op 42000 woningen (* 2 ). In 1958 stelt de Telders stichting (* 3) dat de inhalmanoevre, op enkele regionale tekorten na, reeds is voltooid. 


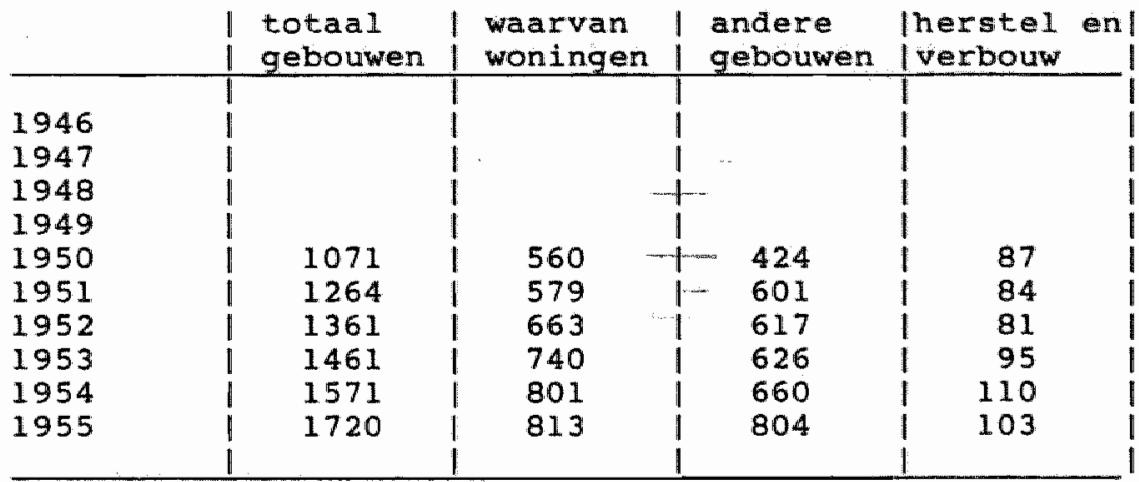

Produktie van gebouwen in mln. guldens Bron: CBS 
Het Economich Instituut Bouwnijverheid in de Bouwnota meldt datentegen in de huurnota 1962 dat dit punt in 1970 hopelijk bereikt zal worden. Goede lange termijnplannen waren woor de bouwijverheid van het grootste belang, mar door de verschillen in opwatingen kwam het daar niet van. terwijl de kontrole op het verloop van het inhalproces volgens Hendriks ook niet goed funktioneerde. Zo kan het gebeuren, dat ondanks de schaarste aan woningen en andere gebouwen in 1952 de werkloosheid in de bouw steeg tot 11,38 tegenover 3,48 van de overige beroepsbevolking (* 5 ). ook uit de cijfers, beteffende het produktievolume van de bouwnijverheid, blijkt en arzelende toename tot 1955 .

IV.1.2

$1955-1972$ de groei

In de periode 1955-1972 zette de verschuiving van de werkgelegenheid van landbouw naar industrie en dienstensektor zich voort (zie grafiek blz. 103)

De uitbouw van de industriele aktiviteiten vroeg niet alleen om personeel, ook de akkomodatie diende te worden uitgebreid. Het gevolg was een sterke stijging van de netto investeringen van het bedrijfsleven.

Weliswaar beeldt de grafiek op blz. 103 in investering in totalen vaste activa uit, dus met inbegrip van produktiemiddelen, maar toch geeft het een goed beeld van de groell juist op het gebied van de utiliteitsbouw; zeker als men in aamerking neemt dat in deze cijfers mede zijn begrepen de investeringen t.b.v. de administratieve sektor van het bedrijfsleven. Tussen 1958 en 1968 stijgt de industriele produktie met 7,28 per jaar. Teruggerekend naar het peil van 1938 betekent dat een groei van 4,3 in 1968 . Deze groei komt mede ten goede aan de utiliteitsbouw (* 7 ).

Een katalyserende faktor voor de utiliteitsbouw is de fusiegolf in het bedrijfsleven, veelal dwingt het samengaan en de daamee gepaard gaande schaalvergroting tot bouwkundige aktiviteit. Het aantal bij fusies betrokken N.V." s loopt na 1958 snel op:

$1958-96$
$1963-254$
$1964-374$
$1965-508$
$1966-349$

De teruggang in de fusiegolf in 1966 valt samen met een optredende werkloosheidspiek (zie grafiek op blz. 104)

ook van buitenaf kwamen impulsen. Tot 1 juli 1969 werden in Nederland 555 dochterondernemingen wan buitenlandse firma's gevestigd $(* 5)$. 


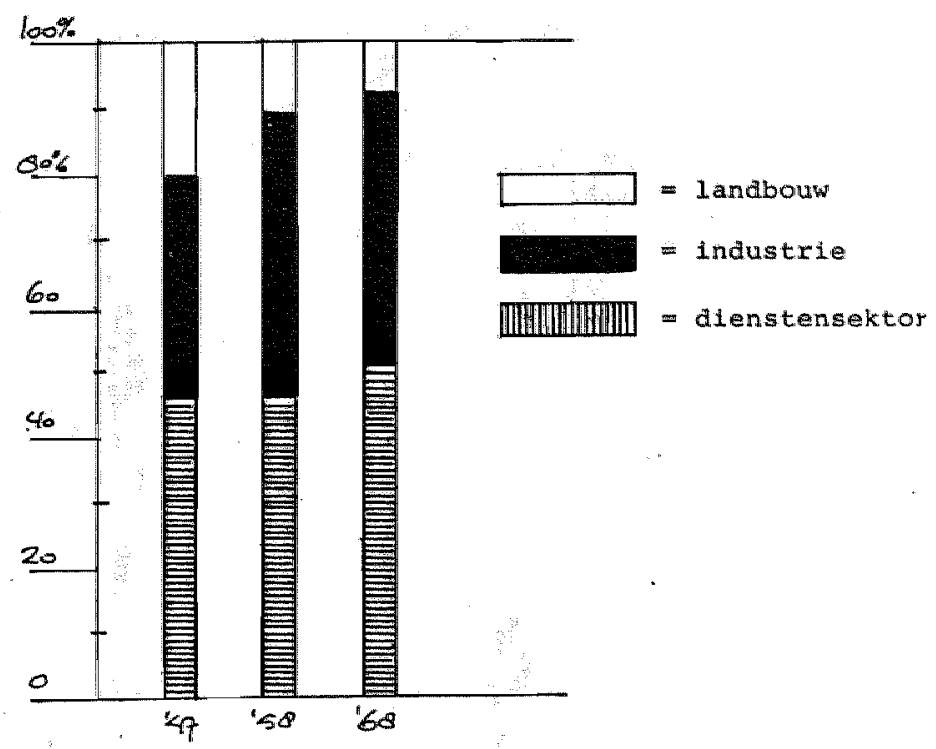

Werkge legenhe Idson twkke ling 1947-1968

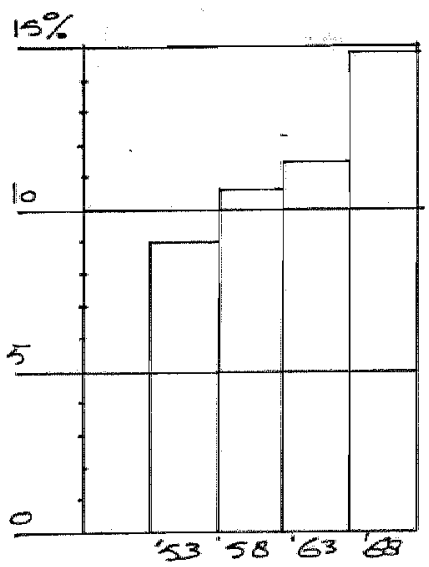

Netta-1nvesteringen vaste activa van

Bedrijven in van het national inkomen $1953-1968$

Bron: "Bouw" nr, 17, 1970 
volume produktie

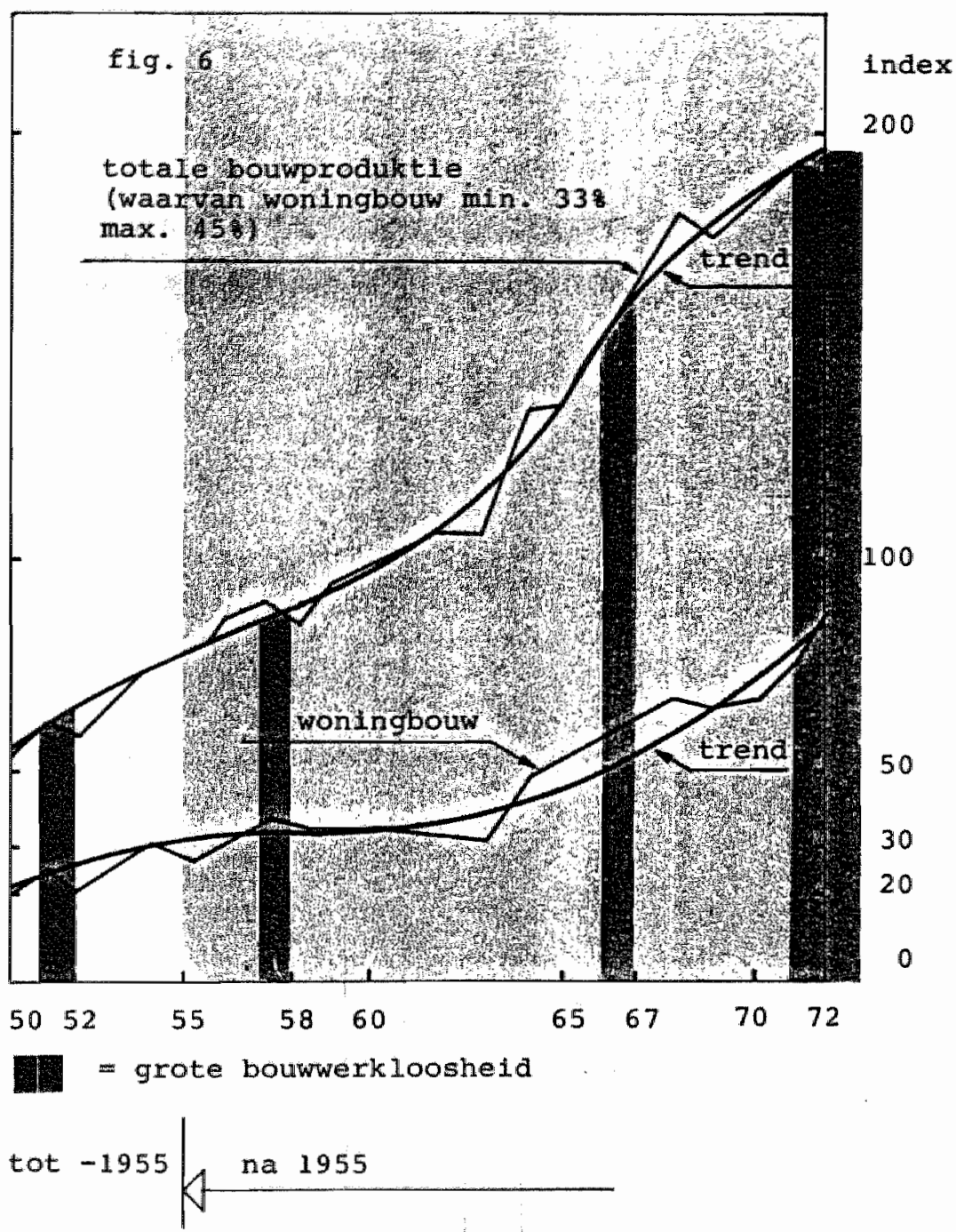

Bron: Hendriks - De veranderende bouwopgave 
Voor de woningbouw was van belang dat de bevolkingsgroei tot 1970 toenam tot 50 s boven die van 1945 hetgeen ook in het jaarlijkse kwantum gesubsidieerde woningen tot uitorukking kwam.

Toch bleef er een niet evenwichtige relatie bestaan tussen de trendmatige groei van het bouwvolume en de beachikbare bouwkapaciteit (zie grafiek op blz. 104)

Hendriks vat de problematiek van deze periode als volgt samen: "averzien wij de periode 1949 - 1972, dan kan in het algemeen worden vastgesteld dat zij die de bouwwereld vormen ieder voor zich en op eigen wijze zo slagvaralig mogelijk hebben gereageerd op de ontwikkeling van de bouwopgave onder invloed van de ekonomische groei die zich in genoemde periode voltrok".

Het probleem was evenwel de vaststelling en de formulering van de bouwopgave, mede in relatie tot die groei. Dit probleem is steeds moeizaam onderkend.

Tot de opvallende verschijnselen van vo6r 1972, die ook de bouwwereld betreffen, behoren volgens Hendriks naast de ekonomische groei onder meer:

- de ontwikkeling van wederopbouw naar ruimtelijke ordening

- omvang van de bouwproduktie bijna volledig bepaald door de op uitbreiding van de voorraad gerichte produktie

- relatief stijgende bouwkosten

- bevordering van grootschaligheid

- bevordering van het bouwen zonder bouwvakarbeiders

- ontwikkeing van specifieke technieken naast de bestaande generieke technieken

- drang tot integratie en specialisatie

- aanwezigheid van alternatieven (*6)

De onmacht tot het beheersen van de feitelijke bouwopgave klinkt ook door in de inleiding van minister Bogaers' nota betreffende een pluriform en expansief bouwbeleid (1963) warin hij zich afvraagt: "waarom het zover moest komen. was eerder ingrijpen niet magelijk geweest?"

De teruggang in de bouwnijverheid in 1952 en 1958 waren volgens Henariks het gevolg van ontwikkelingen die voortsproten uit situaties die niets met bouwen van doen hadden, nl. de Korea-krisis respektievelijk de bestedingsbeperking die het gevolg was van een groot tekort op de betalingsbalans. De terugslag van 1967 was

struktureel, in dat jaar overtrof de bouwkapaciteit, in 't bijzonder de arbeidskapaciteit de toen aktuele en te verwachten vraag nat bouwproduktie.

De werkloosheid van 1972 betekent het feitelijke keerpunt in de groel van de bouwproduktie. 
IV. 1.3

$1972-1985$ de kentering

Volgens Hendriks (* 7) verliest de stuwende kracht voor de bouwproduktie, nl. de noodzakelijke witbreiding van de voorraad na 1972, vooktdurend aan betekenis. Daarbij zij a angetekend dat de kromme uit de graflek op blz.104, die de voorrad registreert, afhankelijk is van andere grootheden die de bouwproduktie bepalen, ni. uitbreiding, vervanging en rehabilitatie, omvang en samenstelling van de bevolking, van de werkgelegenheid, eisen aan de infrastruktuur te stellen enz. Hij stelt dat ook het latste kwart van deze eeuw daarin geen verandering zal brengen. Er vindt een geleidelijke verandering van de bouwopgave plats. Van produktievraagstuk naar inrichtingsvraagstuk. Dat laatste impliceert een veel grotere betrokkenheid van andere leden van de maatschappij, dan de traditionele bouwpartners in het bouwproces bij deze bepaling van de kwaliteit van de gebouwde omgleving. Het gaat om de positie van het bouwrak in zijn volle, gedifferentieerde, omvang ten opzichte van de rest van de matschappij. Daarmee wordt de bouwwereld opengebroken, vooral in de planfase van de bouwopgave.

Een volstrekte eenstemmigheid in het cijfermateriaal aan bouw-ekonomische zijde voor wat betreft de analyse van de teruggang en de toekonstvisie is uiterst moeilijk te ontdekken. Het kommentaar van drs. G.E. Engberts op het tweede rapport van de commissie Bouwplanning (* 8) in 1973 is daarortrent duidelijk. Wanneer wij ons baseren op de gebouwenproduktie als geheel, dan zien wij dat eigenlijk pas in 1980 een scherpe daling wordt ingezet. Sommige cijfers laten zelfs een duidelijke doorgroei van de bruto bouwproduktie zien tot 1980 , zoals blijkt uit de cijfers van het AvBB op blz. 107. Wellicht ten overvloede zij opgemerkt dat de uit verschillende bronnen gehanteerde cijfers niet onderling op ellkar zijn afgestemd, en dus niet absoluut moeten worden beschouwd. Het gaat hier immers slechts om het signaleren van een algemene trend. Ierwille van de duidelijkheid zijn hierin de hoofdkomponenten utiliteitsbouw en woningbouw samengetrokken, hoewel ze op zichzelf onderworpen zijn aan verschillend gestuurde mechanismen. De woningbouw immers is sterk bepald door politioke faktoren, vanwege de verwevenheid met de sociaal-politieke komponenten van de volkshuisvesting.

De wiliteitsbouw daarentegen is voor een overgroot deel athankelijk van de groei van het bedrijfsleven. De geschetste trend is gerelateerd aan het geproduceerde bouwolume.

In de behandeling van de specilieke situatie van de architektenbureaus zal duidelijk worden dat tussen deze produktie de algemeen ekonomische situatie een silipverlies zit van vele jaren in de vorm van 
PRODUKTIE IN DE BOUWNIJVERHEID (NAT. REK.)

in mln. guldens, exkl. BTw, lopende prijzen

\begin{tabular}{|c|c|c|c|c|}
\hline $\begin{array}{l}1954 \\
1955 \\
1956 \\
1957 \\
1958 \\
1959 \\
1960 \\
1961 \\
1962\end{array}$ & $\begin{array}{l}4.000 \\
4.396 \\
5.107 \\
5.742 \\
5.583 \\
6.010 \\
6.443 \\
7.038 \\
7.484\end{array}$ & $\begin{array}{l}1969 \\
1970 \\
1971 \\
1972 \\
1973 \\
1974 \\
1975 \\
1976 \\
1977\end{array}$ & $\begin{array}{l}16.450 \\
18.553 \\
21.000 \\
23.170 \\
25.300 \\
26.900 \\
29.210 \\
32.350 \\
36.980\end{array}$ & \\
\hline & & \multicolumn{2}{|c|}{------------} & revisie \\
\hline $\begin{array}{l}1963 \\
1964 \\
1965 \\
1966 \\
1967 \\
1968\end{array}$ & $\begin{array}{r}8.037 \\
10.370 \\
11.571 \\
13.096 \\
14.817 \\
16.750\end{array}$ & $\begin{array}{l}1977 \\
1978 \\
1979 \\
1980 \\
1981\end{array}$ & $\begin{array}{l}42.460 \\
47.020 \\
49.070 \\
55.240 \\
52.470\end{array}$ & \\
\hline
\end{tabular}

In 1977 heeft een statistische revisie platsgevonden een en ander houdt in dat de cijfers vóór en ná 1977 niet te vergelijken zijn.

Bron: AVBB 
Voor de teruggang van de utiliteitsbouw na 1980 moet de oorzaak worden gezocht rond 1973 (aliekrisis, begin van een a lgemen ekonomische teruggang). Bij de woningbouw liggen daaran nog andere oorzaken ten grondalag, voornamelijk op planologisch gebied (verlaten van de groeikerngedachte, opkomst stadsvernieuwing), watrij het beeld nog verder wordt vertroebeld door de kunstmatige stimulering van de vraag d.m.v. de subsidie-politiek in positieve zin en in negatieve $z i n$ door de hoge rentestand en het rijpend inzicht dat de ekonomle stagneert wardoor de burger arzelt al te grote financiele verplichtingen an te gaan.

IV. 2

De matschappelijke plaatsbepaling van de architekt in zijn verhouding tot de opdrachtgever

IV.2.1

$1945-1955$ de wederopbouw

IV. 2.1 .1

de architekt nog een maatschappelijk middelpunt?

Het is wellicht goed on de reaktie van de BNA op het voorontwerp voor een Bedrijfsschap voor het Bouwwezen als uitgangspunt te nemen (*9). Dit voorontwerp had ten doel om in het kader van de Publiekrechtelijke Bedrijfsorganisatie een overzichtelijke struktuur te scheppen in bepaalde sektoren van het bedrijesleven, zowel in ekonomisch als sociaal opzicht. Uit dit kommentaar van de BNA blijkt dat deze organisatievorm daardoor was gestoeld op werkgevers- en werknemersbelangen, en niet op een organische struktuur van alle krachten die het bouwvak toen bepalden. Men eiste als architekten, omdat deze in de leiding van de produktie een beslissend aandeel zouden hebben, een plaats op zowel in de Ekonomische Kamer als in de Sociale Kamer van deze organisatievorm. Men refereerde daarbij aan reeds vóór de oorlog (1940 - 1945) begonnen pogingen tot een ordening in de participanten van het bouwgebeuren op initiatief van BNA, ONRI, VDI en Rijkswaterstaat, zijnde "directies". Die ceferte was echter niet juist.

Het ging daarbij toen om de definitie en de afbakening van scheidsijinen tussen de beroepsvelden architekt, ingenieur en annemer. Nu echter om problemen van financiering en werkgelegenheid. Deze faktoren hadden de grootste aandacht bij het herstel en het inlopen van de achterstand. Vrije beroepen hocen trouwens in de PBo niet thuis. Zij lagen meer in de bedrijfsifeer van de annemer dan van de architekt.

De claim zal dan ook meer zijn voortgekomen uit de vooroorlogse gedachte dat de architekt sowieso en centrale rol in het bouwgebeuren innam, dan uit inzicht in de 
feitelijke problematiek van dat moment.

Meeuwese konstateert (* 10) dat in de periode na de oorlog " vooral in de woningbouw, het hoofdaccent op de aannemer

lag. Dat sproot mede voort uit de belangstelling voor systeembouw vanwege arbeidsbesparing en verkorting van de bouwtijd. De stichting Ratiobouw stimuleerde dan ook in die richting. Volgens Meeuwese is daarom in die periode de architektenrol meer van ondersteunende aard, althans war het de woningbouw betraf, en dat was het grootste deel van de bouwaktiviteit in die eerste na-oorlogse jaren.

Druk hadden de architekten het kort na de oorlog al wel. Om in aanmerking te komen voor een rijksbijarage in de kosten van wederopbouw, was men verplicht een architekt met een herbouwopdracht te belasten. De betaling van de honoraria darvoor leverde echter nogal eens problemen op. Architekt Wesselo (* 11) signaleerde tenminste dat tientallen architekten met de financièle ondergang werden bedreigd. De rijksbijdrage werd kennelijk nogal eens pas na verloop van veel tijd verleend, en dan nog voelden veel opdrachtgevers er niet voor daaruit de vorderingen van de architekt te voldoen.

Niet alleen de architekten kenden zo hun problemen, ook het uitvoerend bouwbedrijf ondervond moeilijkheden. Het Rijksgoedkeuringenbeleid trachtte de bouwmarkt te reguleren, maar het daardoor ontstane tekort aan werk deed, in kombinatie met de openbare aanbesteding, situaties ontstaan die een kwalitatief goed gebouwd produkt in de weg stonden (* 12). Slechte bouwbedrijven grepen hun kana terwijl prijskorrekties, uit zelfverdediging door de aannemerij, felle kritiek uitlokten van opdrachtgeverszijde. Hoewel men anders zou verwachten is in de bouwliteratuur uit deze dagen geen protest of kommentaar te vinden van de zijde van de architekten.

Betekent dat dan dat de architektenstand het kwaliteitsververval beschouwde als een zaak tussen opdrachtgever en a annemer?

De architekten hadden in de bedrijfsvoering wel te maken met grote diskontinuiteiten in de ultvoering van opdrachten als gevolg van het vergunningenstelsel. Zakelijk gezien had dat weinig invloed, het kostencijfer van het bureau lag laag, men had weinig personeel.

Dat niet alleen techniek, prijs en ekonomie bepalend zijn voor het werkgebied van de architekt, mar ook architektuur-opvattingen, blijkt uit het betoog van ir. G. Friedhoff op de negentiende Monumentendag (* 13$)$. Daar werd de "aesthetisch-culturele" zijde van de wedecopbouw in het licht gezet. Het doet merkwaraig aan dat enerzijas wordt opgemerkt, "dat wij pas gaan spreken van kultuur wanneer er een gemeenschap is, die een eigen levensvorm gevonden heeft", terwijl anderzijds blijkt dat er sprake is van een diepgaande kontroverse tussen de 
architektuurstromingen nieuw-zakelijk en traditioneel. Deze kontroverse mondt uit in een pur zakelijke konkurrentie wie, behorend tot een der beide groepen, de meeste opdrachten in het kader van de wederopbouw krijgt toegeachowen. De teigen levensvorm" heeft kennelijk verschillende gedaanten.

Deze ambivalentie, kultuurdrager én ondernemer te zijn, wordt in deze periode kenmerkend voor het architektenvak. ook de vobroorlogae periode heeft daarvan de sporen gedragen, Mieras konstateerde dat reeds (* 14 ). Het is toch op $z^{\prime} n$ minst merkwaraig dat in de benarde na-oorlogse jaren dergelijke twistappels over stijlopvattingen groeiden, alsof de vorm in het samenspel van vorm en funktie en eigen autonomie zou bezitten.

Overigens zorgde de zakelijke kant van het vak wel voor kollegiale diskussies, of het moreel oirbaar was dat de ene architekt kennelijk veel werk had en de ander niet. De samenhang van kwaliteit en kwantiteit!

over de zakelijke ongewisheid van het architektenberoep schreef Mieras in zijn eerder aangehaalde artikel "Het avontuurlijke element in het architektenberoep is groter dan het redelijkerwijze mag zijn, het makt de uitoefening van het beroep onnodig riskant"(*15). Deze ongewisheid is bijna kenmerkend voor het architektenberoep alléen. Noch het medische, noch dat der advokaten, noch de andere beroepen, die als vijje beroepen in grondtrekken met dat der architekten vergelijkbaar zijn, kennen dit element van onzekerheid op een zo drukkende wijze als het architektenberaep.

Nast de visie die anderen op de architektenpositie hadden dachten de bouwmeesters zelf ook na over de situatie. In de ontwikkelde toekomstbeelden is uiteraard een belangrijke plaats voor hen zelf ingeruimd. Furneaux Jordan (*17) meent zelfs en sleutelpositie, in een matschappij warin een samenwerking zou ontstaan tussen het administratieve ingtrument, de socialistische staat en het technische instrument en de industrie, met als gevolg dat "de architektuur opnieuw de hoogste plats onder de kunsten kan gaan innemen". De architektenrol verandert dan wel van een kleinere in een groter geheel in plats van allesoverheersend te zijn in kleine zaken. Furneaux Jordan ziet dat als een middel tot verhefing van de architektuur, omdat een zich technisch razendsnel ontwikkelende maatschappij in zijn ogen zónder de architekt, tot een nachtmerrie verwordt. Hij verbindt evenwel stringente eisen aan het fundament van elke matschappelijke positie, dus ook van die van de architekt: de opleiding. Deze kan niet veelzijdig genoeg zijn. 
IV. 2.1 .2

de diskussie rond de ontwerp-architektenwet van 1949

Een goede graadmeter voor het maatschappelijk spanningsveld rond de architekt vormen de diskussies over de ontwerparchitektenwet van 1949. Zij behelsde een beroeps-

bescherming voor de architekt tot an de uitvoering. Men dacht hiermee de planontwikkeling van voorlopig ontwerp tot de uitvoering te "zuiveren" van ontwerpende aannemers.

omdat de wet nooit is angenomen is ze formeel van geen belang voor de ontwikkeling van de rechtspositie van de architekten en is dus niet juridisch, mar wel

matschappelijk van betekenis. Ze kan worden gezien als een poging tot strukturering van de rechtspositie van de architekt. De knuppel werd in het hoenderhok geworpen door de stichting van de Landbouw in har anval op: "de 34 miljoen gulden a ar architectenhonoraria die in de komende 10 jaar aan de agrarjsche sektor zullen worden onttrokken". Vooral de laatste tern ontlokte een groot protest an de architektenstand ( * 16) die de stichting demagogie verweet. De eerlijkheid gebiedt te zeggen, dat de stichting tot de uitspraak zal zijn verleid door de stijgende ergernis over de "architectuurplicht" voor agrarische bouw, welke har grondslag had in de wederopbouwwet.

De ontwerp-architektenwet (* 18) dwong de annemerij tot een duidelijke uitspraak over har positie in relatie tot die van de architekten. Er ontstond dan ook een brief-en notawisseling tussen de Raad van Bestuur Bouwbedrijf en de Minister, warin de bepaling dat slechts een bouwverguning mocht worden afgegeven wanneer de plannen waren opgemakt door een bevoegd (ingeschreven in het Register) architekt" een steen des aanstoots bleek (* 19). Vooral omdat blijkenis de Memorie van Toelichting de scheiding van het beroep van de architekt met andere, w.o. dat van annemer, voorop stond, als zijnde onverenigbaar. De aannemers stelden dat hiermee inbreuk werd gemakt op een reeds lang gevestigde situatie, die door de jaren bewezen heeft in een matschappelijke behoefte te voorzien. Voor het overige bestaat het kommentaar uit een terugwijzen naar de honderden jacen aude traditie van de bouwvakpatroonarchitekt.

Prof. ar. J.M. Bakhuizen van den Brink, voorzitter van de landelijke Architekten Commissie verwijst in zijn repliek naar de Memorie van Toelichting warin op een drietal zaken wordt gewezen:

- dat op social-economisch terrein de band tussen gebruiker en bouwmeester losser is geworden, doordat $z$ ich tussen hen in vele gevallen ondernemingen hebben geplatst, welker streven uitsluitend is gericht op het maken van winst:

- dat een sterkere differentiatie is opgetreden in de aesthetische begaafdheden van hen die zich architekt noemen:

- dat de door gemeenten, provincies en partikulieren 
toegepaste bemoeienissen uit hoofde van de Woningwet 1901, inzake de schoonheld vere van toereikend zijn.

De schelding tussen het "meer ldeële architektenberoep" en de "annemersonderneming" leek Bakhuizen van den Brink alleen mar gelukkig om met de architektuur op werkelijk hoog peil te blijuen en om misverstanden te voorkomen, tot heil van beide partijen.

Hif betreurde het, samen met de $B N A$, dat de direktie over de ulitvoering niet tot het architektenberoep werd gerekend. ondat "uitvoering veelal wel kan geschieden zonder dat een architekt over die uitvoering de direktie voert"

De arehitektenwet ontlokte aan ir. J.H. Alberda b.i. een ontboezening ontrent de betutteling van de architekt door middel van beperking bouwkosten, materialen, volumen, supervisor, schoonheidskomissies (schoonheidsregelaars) en bouwverordening $(* 20)$.

De redaktie wees in har kommentaar op het feit dat de architektenwet pas op zeer lange termijn de architekt een zodanige status kan geven dat aan deze betutteling een einde kont, gezien de lange overloop-termijn, zodat de kwaliteit niet op slag verbetert na aanneming door de Kamer van het ontwerp. Zij wees er voorts op dat de BNA de opleiding van de architekt als het meest dringende punt in haar programma heeft, omat slechts dát een warborg voor kwaliteit kan zijn.

Ook de professionele opdrachtgever mengde zich in de diskussie ten faveure van de architekten: "De verhoudingen in het bouwvak zijn ook zo gegroeid, dat ontwerpen niet meer tot de taak van de aannemer behoort. De alannemer is de uituoerder van de gedachten van de architekt geworden. Deze latste konstrueert op papier en de aannemer voert deze konstrukties uit, onder toezicht van de architekt. Koopmanschap en organisatievermogen zijn eigenschappen warop in de aannemerswereld méer de klemtoon valt dan op technische kennis, al wil hiermee niet gezegd zijn, dat deze latste geheel gemist kan worden. Het gaat hierbij chter meer om technisch inzicht dan om technische kennis aldus A.D. van Eck, hoofd van de Bouwkundige Afdeling van de Directie wieringermeer.

Mar ook de architekten onderling waren verdeeld over het wetsontwerp nar bleek uit de polemiek van ir. G. Friedhoff en ir. A.J. van der Steur $(* 22)$. De eerste wijt de toenemende regelgeving in het vak an het eveneens toenemende gebrek aan vakkennis van de architekt...De vorige poging om de status van de architekt via de wet te regelen strandie op het gebrek aan een ensluidende visie in de gelederen. Daarom stichtte men het Register met ruime toelatingsmogelijkheden. Te ruim vond Eriedhoff. Hij stelde: eerst een perfekte opleiding, en dan de plats bepalen van die opgeleiden. Van der steur stelt daarentegen dat deze wet het begin is van een tijd warin een nieuwe generatie architekten kan ontstan, uitgaande van het 


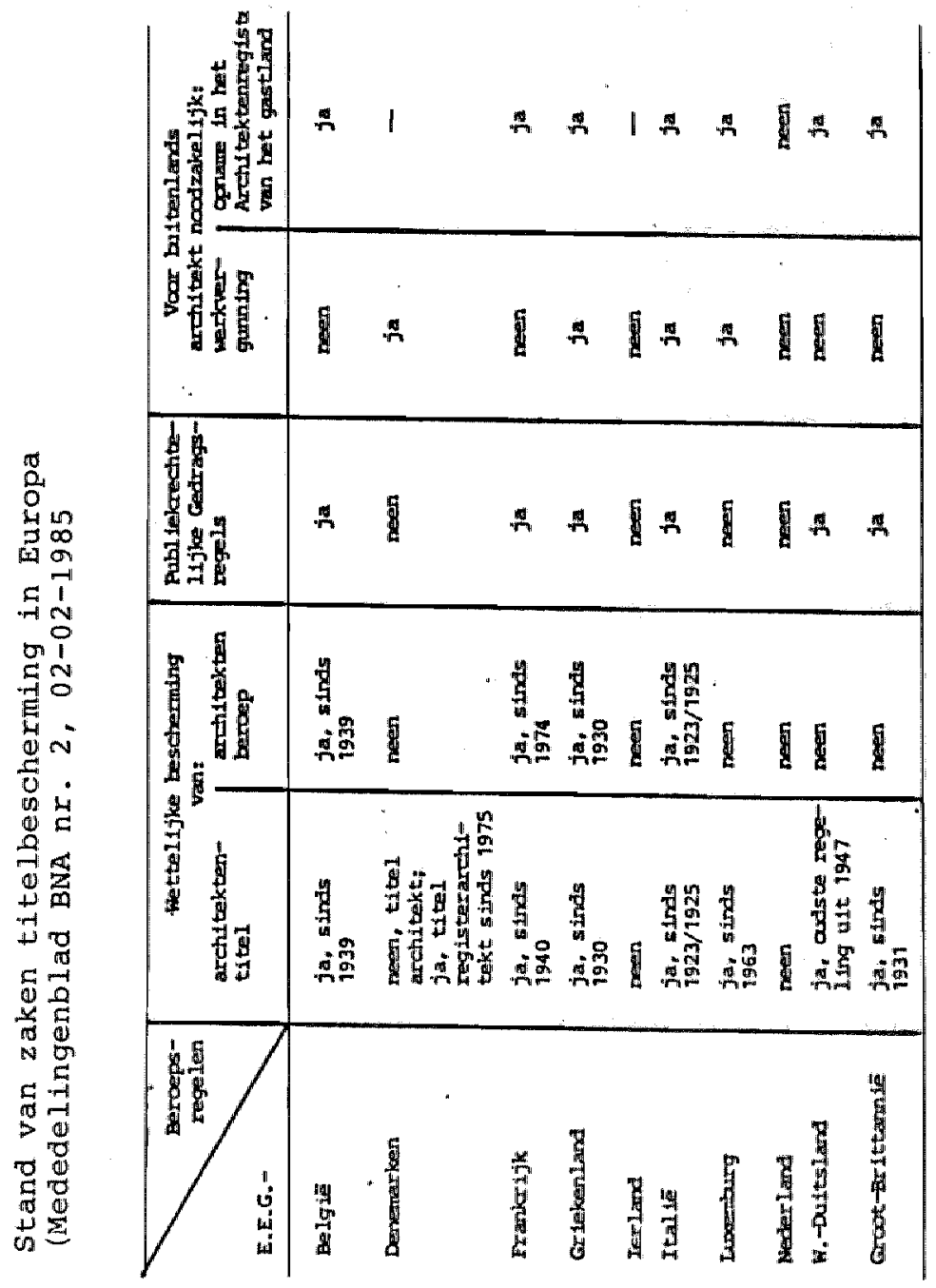


huidige corpa van misschien minder hoog gekwalificeerden. Hij gat ook in op het bezwar van architekt Boeken tegen de ultaluting bij deze beroepsbescherming van de

direktievoering. Hij verdedigt dit met de opmerking dat anders onoverkomelijk moejlijkheden zouden ontstaan met de partikuliere woningbouw "die altijd principieel de uitvoering in eigen hand houdt" alsook de situatie rond de geprefabriceerde woningbouw warin het hoofdaccent door de uitvoerende partijen werd gelegd. Dat het kommentar het cumoer inleidde dat om de behandeling van het wetsontwerp zou ontsaan, voorzag de redaktie van het $B W$ in haar nascheift al.

De architekt Mieras wijdt nog een artikel aan de ongewenstheid on architekten-amnemers of architektbouwvakpatroons tot de beschermde kring toe te laten (*22). De kern van de zaak lag volgens hem in de vertrouwenspositie, immers voorbehouden aan de architekt in zijn unieke onafhankelijke positie.

Het wetsontwerp streeft overigens geen bewoordeling van een beroepagroep na, maar de bevordering van "bouwkunstig" bouwen als algemeen belang. Het beginsel van scheiden van ontwerp en uitwoering ziet hij als een "ideale ondergrond" voor de architekt. Bovendien beroept hij $z i c h$ op een al 150 jaar bestaand stelsel.

In 1950 hield dr. A. Henkemans, direkteur van het Nationaal Grondbezit $N V$, een voordracht welke van belang is voor een inzicht in de positie van de architekt temidden van de uitvoerende digciplines (*23), door de inleider angeduid als "wij ondernemers". Allereerst duidt hij op de dualiteit in het architektenberoep; enerzijds vrij kunstenaar, anderzijds gebonden in zelf bedachte juridische en ekonomische regels in de vorm van tarieven, erecodes en algemene regelen. "Zijn betoog makt duidelijk dat de architekt als kungtenaar wordt gezien en dat de aspekten van efficiency, konstruktie en uitvoering beter aan anderen kunnen worden gelaten. Hij trekt daarbij de in de architektenwet voorziene uitsluiting van de rechtsbescherming van de architekt bij de uitvoering naar voren; tot vóór de anbesteding. Hij signaleert twee visies:

- enerzijds het standpunt dat - hoe wardevol de medewerking van andere bouwdeskundigen (hetzij ambtenaar, hetzij ondernemer) in de opeenvolgende fasen van het bouwproces ook moge zijn, de verwezenlijking van schetsplan tot definitief ontwerp en daarna tot bouwwerk van begin tot einde moet blijven berusten bij de architekt, die het te verwezenlijken objekt reeds voor zijn totstandkoming met zijn geestesoog heeft ontwaard. (De architekt dus als kunstenar die het hele bouwproces beheerst):

- anderzijds van het standpunt dat - de vorm van het te creëren bouwwerk eenmal gegevon zijnde, de kunstenaar 
moet terugwijken voor de oplelding en/of de praktische ervaring van de bekwame bouwdeskundige, warbij een zuivere afweging van de belangen van bij de bouw betrokkenen zal uitmaken, of en in hoeverre deze plaats door de architekt, dan wel door een ander zal worder ingenomen.

$Z$ ijn voorkeur voor het latste was evident. Weliswar erkende hij dat de esthetische rol van de architekt tijdens de latere fasen van het wordingsproces, afhankelijk van de aard van het projekt (soms) niet gemist kon worden doch dat was op te lossen door wat esthetische detalls op grotere schal bij het voorlopig of hoogstens definitief ontwerp te voegen.

In feite is dit de eerste keer dat van gezaghebbende $z$ ijde de architektenpositie in de konceptie-fase ter diskussie wordt gesteld, op grond van zijn gebrek aan inzicht in akonomische en technische implikaties van zijn eigen ontwerp. Vooral het kostenbesef zag Henkemans als een sociale plicht, en daarom vond hij een herziening van de historische tegenstelling architekt-aannemer ten gunste van de latste gewenst (* 24).

Rennelijk is de inleider zich, gezien zijn positie, niet bewust is geweest van de essentie van het architektenberoep nl. het zoeken van een synthese tussen de vele konceptbepalende elementen op grond van de vertrouwensrelatie met de opdrachtgever. Wellicht was voor zijn stellingname, matschappelijk gezien wel enige aanleiding. De heersende scharste (nationale armoede) zal daar wellicht ook debet aan zijn geweest, omdat de "speelruimte" van de architekt extra beperkingen oplegde aan de uitvoerenden. ook de architektenfantasie kost geld, dure ontwerpen laten weinig financiële ruimte voox de uitvoering.

De in de ontwerp-architektenwet 1949 uitgesloten bescherming $v \cdot w \cdot b$. de uitvoeringsfase, verleidde sommigen tot het voorstellen van een centraal orgaan voor direktievoering en toezicht "zodat de architekt zijn handen vrij krijgt voor zijn eigenlijke taak: dat is ontwerpen". litet darmee gepara gaande pleidooi voor uniforme bestekken, begrotingen, administratie en normen, getuigde van een op dat punt vooruitziende blik. Het central organ is er echter, althans op enige schal, noolt gekomen (*25).

Dat verhouding architekt en annemer in samenwerkingsverbanden ook kon leiden tot tuchtrechtelijke ditspraken leert een uitspraak van de Architektenraad, warover een artikel verscheen van de hand van ir. W. van Tijen $(* 26)$. De warschuwing van de Acchitektenraad an de architekt die ontwerpen "leverde" aan een boumbedijf acht Van Tijen, in strijd met een niet te stuiten ontwikkeling. $H_{i j}$ trad hierom zelfs uit de Architektenraad. Hij zag in de samenwerking tussen aannemer en architekt een synthese 
groeien die de gebouwde ongeving zeer ten goede zou kunnen komen. Hij grondveste aijn visie op ervaringen in Engeland en Amerika. "Dat on volk behoorlijk gekleed en geschoeid is dankt het niet an luxe matkleermakers of matschoenmakers, maar aan de moderne kleding-en schoenindustrie. Wij geloven dat deze ontwikkeling, die thans ook in het bouwen algemeen doorzet, ons tenslote het soort wonlngen en scholen zal brengen, dat ons volksleven zo dringend behoeft $(* 27)^{\prime \prime}$.

Voor konkurrentievervalsing ten opzichte van de traditionele ongebonden architekt was hij niet bang. Als deze in het belang is van de prijs, kwaliteit en de verantwoorde architektuur niet bedreigt, moesten de architekten zijns inziens zulk een konkurrentie, mits eerlijk en reeël, aandurven. Hij zag niets oneervols in de rolwisseling van de architekt ten opzichte van het bouwbedrijf in plats van de partikuliere opdrachtgever. Hij wenste dat de BNA het zou kunnen opbrengen om hernieuwde richtlijmen te geven waardoor de architekt ook zijn aandeel in het industrialisatieproces zou kunnen leveren, zonder in konflikt te raken met de heersende regelen.

Dat latste bleek niet uit de rede van de toenmalige voorzitter van de BNA, van der steur, uitgesproken op de ledenvergadering te Utrecht $(* 28)$. Hij herhaalde daar de grondprincipes nog eens van de matschappelijke architektenpositie, nl. volstrekte onafhankelijkheid van de aannemer en het beroep vrij van een kommerciële geest. opnieuw trekt hij, in dezelfde redevoering, parallellen met overige vrije beroepen die matschappelijk well geaccepteerd zijn in tegenstelling tot het architektenberoep. Een dergelijke denkwijze was al oud, immers zij werd ook gebruikt als motivering voor de eerdere Architektenwetten. De parallelien gaan echter mank: ten eerste is er binnen de vakgemeenschap van architekten een grote verscheidenheid in kunnen en kennis. Ten tweede is er een evengrote verscheidenheid in opvatting over de matschappelijke rol van de architekt wan de beroepsgenoten zelf. Ten derde is er een op $z^{\prime} n$ mingt anduidelijke begrenzing tussen het vakgebied wan de architekt en dat van een, ook historisch, nauw verwante discipline, als het uitvoerend bouwbedrije. Dat alles was niet het geval bij adwokaten, doktoren en notarissen.

Met name richt van der steur"s kritiek zich op een snelle doorvoering van de rationalisering van het bouwvak vanwege de "sociale en kulturele gevaren" die dit met zich mee zal brengen. De vorderingen van de Architektenwet besprekend klagt hij over besluiteloosheid van de Tweede Kamer die in de wirwar van vobr en tegen geen besluit wil nemen. wardoor zelfs het voorlopig verslag nog niet is verschenen. Kennelijk pessimistisch over het verdere verloop wan de procedure opperde hij "om via kommissieoverleg tot individuele overeenkomsten te geraken met de 
georganiseerde aannemerij ter bepaling van de bevoegdheden van architekten en aannemers ${ }^{\text {*1 }}$.

De ontwerp-architektenwet bleef verder rusten. De politieke diskussie over de afbakening van bevoegaheden bleek te riskant.

IV.2.2.

1955 - 1972 de hoogkonjunktuur

In deze periode blijkt een aantal feiten door uitspraken vanuit diverse hoeken:

- juist in een periode van grote bouwaktiviteit gat de architekt niet met zijn tijd mee, en blijft in eigen ogen de centrale figuur in het bouwproces, anthecht aan de materie (Buskens vs Moholy Nagy-blz.118)

- de lacunes die de architekt laat vallen in het adequat funktioneren in een ontwerpproces dat aan steeds meer en ingewikkelder voorwaarden moet voldoen, worden, zij het arzelend, opgevuld door het uitvoerend bouwbedrijf en derden. De architekt verliest aanvankelijk ongemerkt (voor zichzelf) terrein (Thunnisen vs Van Praag- blz.121) 66k in zijn vertrouwensrelatie met de opdrachtgever

- deze bedreiging van de architekt, zo deze al wordt bemerkt binnen thet ontwerpproces, zijn specifiek tercein, wordt door hem verschillend ervaren:

betuttelend (Werkman-bIz.125), arcogant-konstaterend en tevens minachtend (Van der steur). Niemand komt met konstruktieve oplossingen, integendeel

- het architektenbureau blijft matschappelijk-ekonomisch gezien een zeer onevenwichtig gegeven:

mini-ondernemers enerzijds ( $89 \%$ ), anderzijds (118) extern grootschalig, maar intern volstrekt ongestruktureerd.

Er worden een antal suggesties gedaan tot verbetering van de architekteninbreng, doch vergeefs, kennelijk weet niemand een manier om filosofieên in realiteit te doen verkeren. Er tekenen zich een aantal visies af:

- van architekten:

enerzijds beducht voor een te grote invloed van rationele elementen wardoor de vrije expressie wordt ingeperkt. Anderzijds zich bewust van de dreiging van de "meeliggers, mar toch niet bij machte om de verschuivingen matschappelijk op een positieve manier te vertalen. Sommigen zijn niet vies van vrijages "pour besoin de la cause" met de aannemerij. 
- van aannemers:

de toenemende onvrede met de rol die de matschappij aan de architekten toedicht: primus inter paris. Die verhinder teveel dat ontwerpprocessen meer worden taegesneden op door hen gevoerde werkmethodieken en uitroeringssystemen.

- van opdrachtgevers:

een opkomend ongenoegen in de richting van de architekt (hij is immere de vertrouwensman?) over de dwingelandij van de architekton 1 sche vorm en de daarmee gepaard gaande korten. Het verwjt dat de architekt het bouwproces in zijn zich wijzigende gedaante niet voldoende beheerst.

De in de vorige paragraaf reeds gesignaleerde spanning tusen ontwerpers en uitvoerenden neemt in de periode 19551972 anel toe. In het koor van aannemers mengen zich ook anderen, van neutralere huize. Zeer opmerkelijk zijn in dit verband de uitlatingen van ir. H.M. Buskens. direkteurgeneraal woor Volkshuisvesting en Bouwnijverheid, utgesproken op de jaarvergadering van de BNA in 1958 (* 29). Onverholen kritiek: "was zijn (de architekt) ilistere voorganger een allround technicus, de architekt wan rond 1900 ziet schichtig hoe de techniek hem voorbij streeft en buiten hem om tot ontwikkeling komt. De matschappelijke wardering is gering, het publiek weet niet goed meer welk aandeel hij, de architekt, in het tot stand gebrachte bouwwerk heeft gehad". Het is daarom geen wonder dat in 1908 de BNA werd opgericht. Vijftig jaren hebben de architekten in Nederland gezocht naar normen voor de vakbeoefening en getracht hun positie in de matschappij te bepalen.

Buskens zegt voorts "het bouwproces is niet meer een kunstambacht dat op zichzelf beoefend wordt, mar is verweven in een meervoudige technische, ekonomische en sociale problematiek. Het gebouw stat niet op zichzelf, maar zal zich moeten onderschikken in de stedebouwkundige samenhang van wonen, werken, verkeer en ontspanning; het is soclal geintegreerd. De bouwmeester is niet de solitaire en allesbepalende schepper van het kunstwerk, hij is een medewerker in de meest letterlijke zin. De opgave voor de architekt van deze tija is, dat de techniek weer zo wordt beheerst dat de vakman ermee kan spelen".

Dat zulks een stuk zelfoverwinning zal eisen van de architekt, konstateerde de voorzitter van de BNA al in zijn openingswoord voor dezelfde vergadering (*30).

Ook in vorige hoofatukken zagen wij een probleemveld in de wilselwerking tussen kunst en techniek, het blijvende dilemma van architekten. Tegenover het pleidooi van Buskens stat de visie van somige vormgevers zoals prof. Moholy Nagy (*39), die stelt dat architektuur het meest is geslaggd, wanneer zij a an de ideële afspraken van een tijdperk een dusdanig sterke expressie verleent, dat het 


\begin{tabular}{|c|c|c|c|c|c|}
\hline & 1 & $\begin{array}{l}\text { totaal } \\
\text { gebouwen }\end{array}$ & $\begin{array}{l}\text { waarvan } \\
\text { woningen }\end{array}$ & $\begin{array}{l}\text { andere } \\
\text { gebouwen }\end{array}$ & $\begin{array}{l}\text { Iherstel } \\
\text { | verbouw }\end{array}$ \\
\hline 1955 & 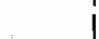 & 1720 & 813 & 804 & 103 \\
\hline 1956 & 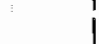 & 2063 & 1104 & 850 & 109 \\
\hline 1957 & I & 2393 & 1402 & 877 & 114 \\
\hline 1958 & i & 2371 & 1352 & 898 & 121 \\
\hline 1959 & 3 & 2632 & 1417 & 1077 & 138 \\
\hline 1960 & 1 & 2769 & 1402 & 1205 & 162 \\
\hline 1961 & 1 & 2799 & 1440 & 1207 & 152 \\
\hline 1962 & 1 & 2908 & 1429 & 1327 & 152 \\
\hline 1963 & 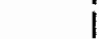 & 3337 & 1625 & 1526 & 186 \\
\hline 1964 & 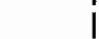 & 4606 & 2270 & 2073 & 263 \\
\hline 1965 & 1 & 5213 & 2689 & 2251 & 273 \\
\hline 1966 & i & 6073 & 3067 & 2702 & 304 \\
\hline 1967 & i & 6998 & 3608 & 3094 & 296 \\
\hline 1968 & i & 7960 & 4095 & 3471 & 394 \\
\hline 1969 & 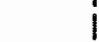 & 8457 & 4317 & 3743 & 397 \\
\hline 1970 & 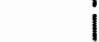 & 8396 & 4182 & 3837 & 377 \\
\hline 1971 & & 9546 & 4964 & 4134 & 447 \\
\hline 1972 & & 10859 & 6346 & 3960 & 554 \\
\hline & I & & & & \\
\hline
\end{tabular}

Produktie van gebouwen in mln. guldens Bron: CBS 


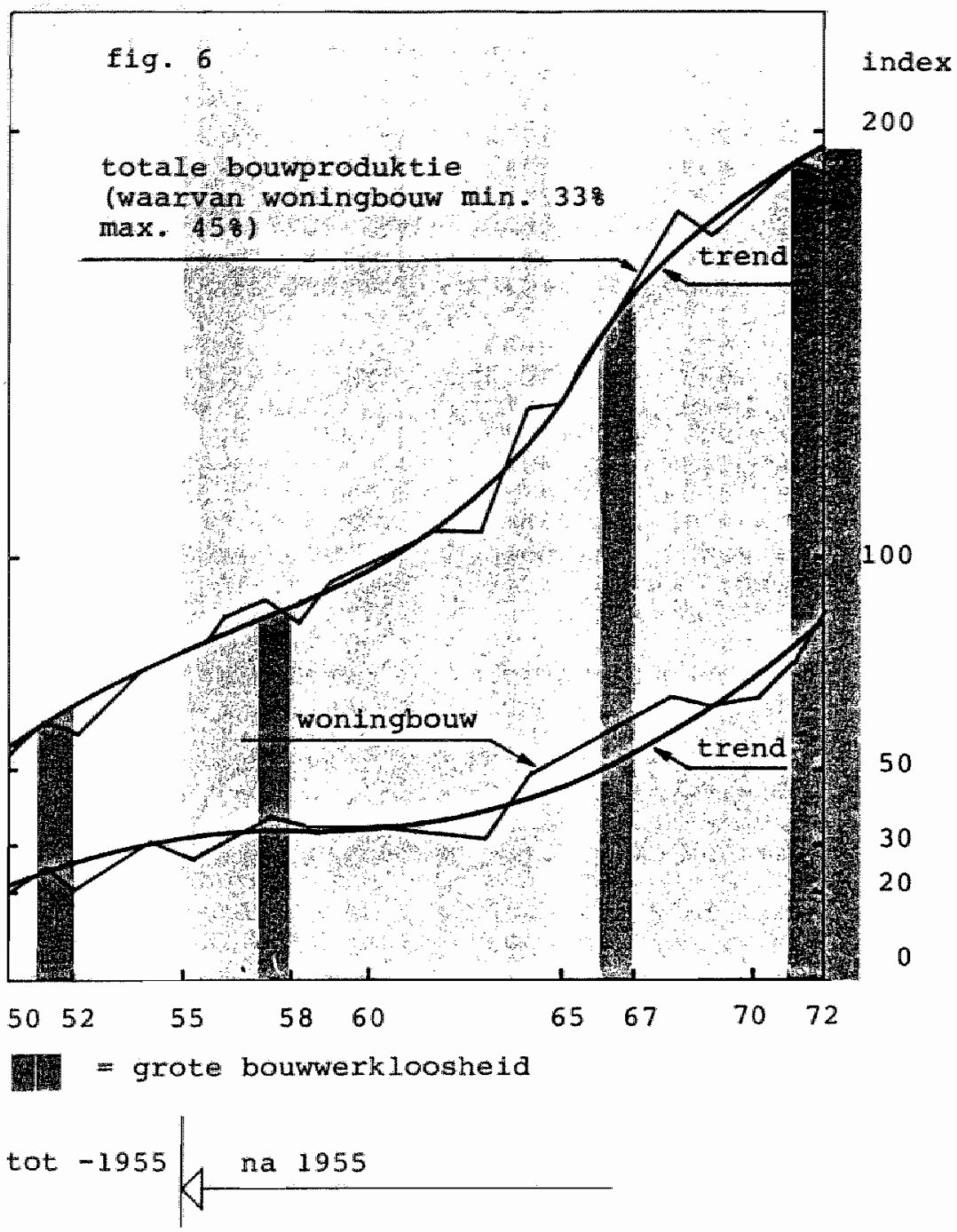

Bron: Hendriks - De veranderende bouwopgave 
latere generaties onverschillig is of het dak dicht en het gebouw exploitabel is.

Hoe onduidelijk het rollenpatroon architekt-aannemer was, mag blijken uit een repliek van mr. H.O. Thunnissen aan mr. ir. M.M. van Praag (*32) ten a anzien van diens visie dat in de systeembouw de rol van de architekt wordt teruggedrongen, en de rol wan het uitwoerend bouwbedrijf primair worat in de relatie met de opdrachtgever. Thunnissen is het niet duidelijk warom in dat geval de positie van de architekt $z i c h$ zo revolutionnair zou wijzigen, omdat immers niet de bouwwijze of de relatie opdrachtgever-aannemer relevant is, maar de vertrouwenspositie van onafhamkelijke architekt.

Is het bezorgaheid dienaangande die de architekt J.J.P. Oud doet zeggen:

"de architect moet $\mathrm{zich}$ - vooral nu - opnieuw vertrouwd maken met de gedachte, dat hij de leider is van de bouw. Niet het agglomerat van esthetische adviseurs, schilders en beeldhouwers enzovoorts, die door zijn onverschilligheid op zijn stoel gaat zitten".

"Bij de architecten ontbreekt de moed, de trats en de lust om het bouwen, hun persoonlijke bouwen ook, weer een eigen gezicht te geven. ze moeten weer veel en veel meer idealist worden. Ik denk wel eens, dat ze door de aard van het vak tegenwoordig toch te veel politici geworden zijn in het beroep in plaats van staatslieden in de bouwkunst. Dat ze toch meer de huik naar de wind hangen dan ver vooruit in de toekomst blikken. En toch kan de architectuur alleen dan weer als een volwaardige kunst meedoen als ze en perspectief voor zich heeft. Een perspectief, dat mijnentwege nog 10.000 jaren en meer, ver weg ligt, max dat meer is dan het doodlopend slop, warin men aan zijn doel is als de raampjes volgens de mode van de dag "esthetisch" verspringen en als de kleurtjes het bekende reidansje uitvoeren, dat momenteel up-to-date is".

"Dit kost meer dan tija: het kost zelfopoffering!

Henry van de velde, de bekende Belgische architect, zei eens tegen mij: "Wil je wat van betekenis maken in het bouwen, dan moet je ervoor betalen". Ik hoop dat de architecten langzamerhand rijp zijn om woor het bouwen weer te willen betalen. Meer dan nu al regel is!".

Uit zijn rede op de Hogeschooldag van de TH-Delft januari 1959.

In de zestiger jaren komt langzarm een einde ar de passieve rol van de opdrachtgever. Als eerste openlijk symptoom daarvan schetst dr. C.H. van der Leeuw in 1961 de voordelen van het programmeren van bouwopgaven zonder architekteninbreng "omdat deze daardoor te vroeg zijn invioed zou kunnen uitoefenen, vanwege $z i j n$ uit vak en gevoel voortkomende drang al dadelijk in vorm en samenhang te gaan denken" (* 33$)$.

overigens is het gehele beeld van het bouwvak, vooral op het 


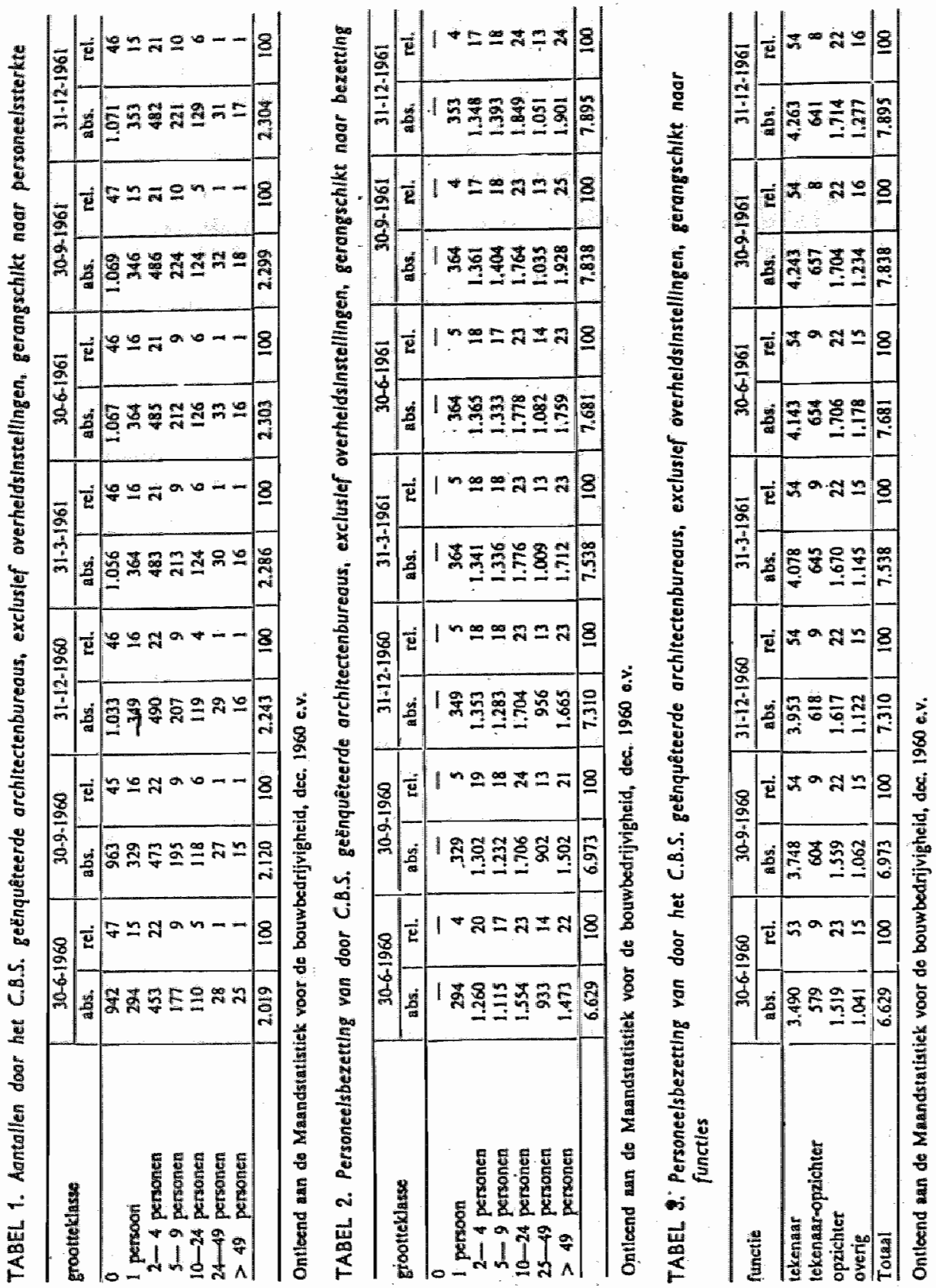

Uite: Bouw 1962 nr. 35 
gebied van de woningbouw in deze periode onderhevig an kritiek. Pen signaleert ( 34 ) een trage groei in de produktiviteit: "het bouwvak is te veel blijven steken in de sfeer van het ambacht, het ad hoc karakter van de bouwplats vergeleken met de fabriek: al te geringe kapitaalsintensiteit, te kleine produktie-eenheden, die een erfenis van moeilijke arbeidsverhoudingen en lage arbeidsprestatie is". Hij konstateert dat de noodzakelijke kapaciteitsuitbreiding bij de bouwbedrijven achterwege blijft uit wantrouwen voor de matschappelijke situatie, vrees voor marktverzadiging, overproduktie en werkloosheid. Verder is er een kwaliteits-inflatie door gebrek aan konkurrentie en een belemmerende houding van de overheid door o.m. de bouwoorschriften. Deze faktoren geven Pen aanleiding tot signaleren van een "culturele vertraging", althans wat de wooncultuur betreft, ten opzichte van de verdere technologische ontwikkelingen.

Het is aannemelijk dat zo"n filippica leidt tot reaktes uit de architektenwereld. Deze voelen zich immers verantwoordelijk voor de gebouwde omgeving, zeker in relatie tot de sociale kant van de zaak. Dat valt echter tegen. In dit verband is een visie op het architektenbureau, anno 1962, van G. Werkman interessant (*35). Hij schetst de tegenstelling tussen de amerikaanse situatie, warin de architekt alle wensen vervult van de opdrachtgever. inklusief de dartoe behorende bedrijfsleider van de te bouwen fabriek, de marktanalyse enz. en de nederlandse. Hij hekelt de verzuchting van de vakbeoefenaar dat het vak achteruitgaat in aanzien, in culturele betekenis en in matschappelijke warde. Werkman beziet de verandering ten opzichte van de status van andere beroepen relativerend, immers, de oude bouwmeester "is nu eenmal geen stilstaande pion op het schaakbord van het leven":

in het oude Egypte - hoge ambtenar

in het klassieke Griekenland - beeldhouwer

in de Romeinse cultuur - politicus

in de Middeleeuwen

in de Gouden Eeuw

in de $T t$. Renaissance

- geestelijke

- steenhouwer

- le man op het bouwwerk

thans

- de beni jdenswaraige man, die zich in deze zich total. vernieuwende a driftig bouwende wereld, als geen ander kan uitleven in stoutmoedige verbeeldingskracht".

Hij signaleert echter tevens een bedreiging van deze positie door de oprukkende regelgevers, (zoals ook pen reeds releveerde), en a nverwante disciplines, waronder de efficiency-bureaus met hun "knellende" adviezen. "De architekt vecht niet alleen voor zijn werk, max soms ook voor zijn status". De architekt worstelt met zijn 
plaatbepaling in suaties die leiden tot schalvergroting" ook binmen het architektenbureau. "Hij waagt zich soms wel af, wat hij eigenlijk nog zelf doen mag, war zijn plaats is in het geheel", alus werkman.

Hoe groot is de bureau-omvang begin 1960 ?

In 1961 blijkt bijna de helft (1071) van alle partikuliere bureaus (2304) nog zonder personeel te zijn. zie tabel 1. Tabel 2 lat en groei zien van de hele kleine en de hele grote bureaus. Het eerste wordt toegeschreven aan een sterke zelfstandigheidsdrang bij architekten, beginnende architekten zijn kleine starters. Echter 248 van het totale nederlandse architektenbureaupersoneel is in 1962 gekoncentreerd in 17 bureaus.

En wie is de opdrachtgever?

Naar herkomst geoordeeld zijn de opdrachten voor een groot deel uit de partikuliere sfeer afkomstig. Gemeenten en woningbowwerenigingen verstrekken $20 \%$ van de woningbouwopdrachten. De overige $80 \%$ komt van partikulieren. slechts 3\% van de architektuur wordt ontworpen door rijksarchitekten en 108 door gemeente-architekten. Van alle opdrachten gaat 90\% naar partikuliere architektenbureaus (* 36). Werkman stelt dat de meerhoofdige leiding van het architektenbureau veel voorkomt, maar dat een funktionele verdeling van werkzamheden niet plaatswindt. De wederzijase belangstelling voor elkars werk neemt af naarmate de onvang van het bureau toeneemt. "Het bureau krijgt daardoor min of meer het karakter van een polikliniek, warin men niet veel meer dan het dak, de boekhouder en de telefooncentrale gemeen heeft". Ten aanzien van het management wordt opgemerkt dat de groei van de personeelsbezetting hier en daar gepaard gat met een min of meer nostalgisch en krampachtig streven nat behoud van de gemoedelijkheid en een daarmee gepard gaande algemene afkeer van straforganisatorische en strikt-hiërarchische opbouw van de personeelspyramide. In de moderne bedrijfsorganisatie wordt een dergelijke struktuur aangeduid met "professional bureaucracy" (*37), een vorm bij uitstek ongeschikt voor snelle beslissingen. Een citaat schetst de architekt zoals deze ook van oudsher was: "op een architektenbureau heerst noch diktatur noch anarchie". Wellicht ligt hierin wel een van de belangrijkste oorzaken voor het verspelen door de architekt van de oude bouwmeesterrol voor het totale bouwproces. Het snel inspelen op een zich wijzigende matgchappelijke situatie, nog vór deze zich duidelijk in gang heeft gezet, is bijeen dergeljke struktur geheel onmogel 1 jk.

De feitelijke inflatoire ontwikkeling in de architektenrol treedt nauwelijks aan de dag: enerzijds omdat hij, de architekt zelf, ex nauwelijks ekonomische schade van ondervindt: hij heeft het drukker dan ooit tevoren; anderzijds omdat de tegenvaeters, de nieuwe disciplines op de bouwmarkt, de feitelijke verhouding met de opdrachtgever 
niet direkt verstoorden: ze kwamen erbij. ook meer zakelijk veranderde er voor de architekt op het oog niet zoveel. over de meerkosten voor de opdrachtgever werd door deze nog niet zo zwaar getild. Men kan zelfs zeggen dat sommige architekten de participatie van andere disciplines in het ontwerpproces wel toejuichten, het ontlaste hen van een hoop extra werk warvoor ze valk niet waren toegerust, en wat ze ook niet zeer in waren geinteresseerd. 0ok de uitvoerenden legden zich nog bij de hegemonie van de oude bouwweester neer, het makte ekonomisch toch geen verschil. op het juridisch front waren echter principide vragen an de orde betreffende verantwoordelijkheid en

aansprakelijkheden bij fouten en gebreken: die werden echter veelal bij de uitvoerenden gelegd.

Terzijde kan nog worden opgemerkt dat diskontinuiteiten in de planprocedures a anleiding vormen voor het niet volledig gereedmaken van de werktekeningen vob́r besteding, alsook voor het volstaan met "aanwijzingsdetails" bij de besteding. Men smeerde de werktekeningen uit over de uitvoeringsfase om de onregelmatigheden in het bureauwerk te kompenseren. Een dergelijke gang van zaken wordt vaak ook door de opdrachtgever in de hand gewerkt: hij wil het risiko niet lopen veel geld in een planontwikkeling te steken die wellicht niet verder komt dan de a anbesteding. De hierdoot ontstane stabiele bureausituatie makte het mogelijk om het opzichters- en tekenaarsbestand in stand te houden in de tijd, in tegenstelling tot vroeger, toen zowel de een als de ander per werk werd aangenomen of ontslagen. Natuurlijk werkte de schaarste aan personeel aan deze situatie mee. Ir. A.J. van der steur:

"het beroep van architekt is bezig voor de zoveelste keer te veranderen van karakter. De vrije kunstenaar wordt, soms tegen wil en dank, meer en meer ondernemer met alle aankleve van dien. Zijn vrijheid wordt bedreigd" (* 38$)$.

Eến van de negatieve aspekten van het ondernemer-zijn is het ontstaan van een vast lastenpakket dat sterke groeineigingen vertoont. Voorlopig levert dat nog geen problemen op gezien de eveneens groeiende inkomsten als gevolig van de sterk toenemende omzet van de bureaus.

Howel aarzelend, begint ook de matschappelijke a ituatie van de aannemer erkenning te vinden in de konservatieve architektenkring. Ir. A.J. van der steur grwagt tenminste, in bovenstaand artikel, van een aanzienlijke stijging van het intellektuele en ekonomische peil van deze punt van de "driehoek", en tevens van de meiging van sommige architekten om $z i c h$ het aannemers-overwicht te laten welgevalien en vrijwillig af te zien van in zijn ogen essentiele architektentaken, uit gemakzucht. Filosoferend over de verhouding architekt-aannemer herhaalt hij de bezwaren van 1926 tegen de inlijving van de zelfstandige architekt in het aannemersbedrijf. Hij ontkent de mogelijkheid om en een goede archlltekt én een goede ondernemer te zijn, vanwege de 
atrijdigheid van de comercie en het vije funktioneren van de ontwerper.

Warom Van der steur deze ontboezeming het licht deed zien, is niet duidelijk. Stellig is het zo dat in de verdere ontwikkelingen naar 1970 toe, de scheidslijn tussen het specifieke werterrein van architekt en aannemer dreigt te vervagen, (en daarmee de onathankelijke positie van de architekt), mar of daar in 1963 al tastbare bewijzen voorhanden waren lijkt niet warschijnlijk. Echter, van der steur kende het metier als geen ander, en kan dus zeker over profetische gaven hebben beschikt. Het was het laatste stuk van zijn hand, hij overleed korte tijd later.

Vanuit de aannemerij neigt men inderdaad naar verdergaande samenwerking, omdat "de onderlinge afhankelijkheid van ontwerper en uitvoerder. welke steeds groter wordt, en het ontbreken van een hiertoe geschikte vorm van samenwerking, een remmende werking heeft". Een nog steeds te ambachtelijke aanpak en arbeidsintensieve uitvoering zou daarvan het gevolg zijn, merkt A. Leyten, direkteur van een aannemingsmatachappij op (*39).

Resumerend stelt hij:

- het gehele produktie-apparat van ontwerp tot en met de uitvoering is tot in de verre toekomst niet opgewassen tegen de steeds groeiende behoefte.

- De problematiek van het bouwen is onvoorstelbaar snel uitgegroeid met als gevolg specialisatie en een steeds groter aantal specialisten, die vanaf de ontwerpfase ingeschakeld moeten worden.

- De uitvoeringstechniek is, vooral in verband met de bouwkapaciteit, een faktor geworden welke in het ontwerpstadium niet buiten beschouwing kan worden gelaten.

Een pleidooi voor het bouwteam dus. De vraag kan worden gesteld warom de architekt dan zo onvoldoende het hele bouwfront beheerste, dat deze penetratie van uitvoerenden in zijn specifieke taakgebied onontkoombar scheen? Liepen architekten dan in ontwikkeling achter? speelt hier de oude averaie van somige architekten tegen de rompsiomp ten faveure van hun ontwerpaktiviteit een rol?

Nóg werd de architekt als leider van dit bouwteam gezien, zij het dat zijn taak enige wijziging heeft ondergaan. Enerzijas zullen de partners, die hun vak verstaan, belangrijke bijaragen kunmen leveren, anderzijas echter zullen vele mogelijkheden en oplossingen, die de architekt worden voorgelegd, grote eisen stellen aan zijn vermogen om tot een juiste beslissing hierover te komen voor de inpassing in zijn ontwerp" (* 40).

Het leiderschap van de architekt lijkt dus meer een gevolg van zijn status van voorheen, dan van een strukturele verandering.

ook van anderen komen dezelfde geluiden. H. van Eesteren: 
"De bouwprodukten, woningkomplexen en utiliteitsgebouwen, welke tot stand komen, zijn niet alleen ontstaan door samenwerking wan de meergenoemde driehoek, mar zijn ook het resultat van het denken en de inventiviteit van specialisten op velerlei gebied". Woor een geslaagde samenwerking architekt-aannemer moet de latste willen meedenken terwijl diens vreugde an het werk groter moet zijn dan het verlangen om veel te verdienen. De architekt echter moet "bekwam $z i j n$ in zijn vak, integer in al zijn handelen, niet de hoogmoedige meester spelen, open oor hebben voor vakkundig overleg met de a annemer en een redelijke opvatting hebben over de verdiensten die de aannemer toekomen" (* 41$)$.

Bij al deze intentieverklaringen kan worden aangetekend dat de onafhankelijke positie van de architekt als vertrouwensman van de opdrachtgever behoorlijk in de knel kwam. Immers, in het a anbestedingsstelsel kwam het bouwteammodel niet voor. De prijs/kwaliteit door de architekt namens de aanbesteder kwam daarmee in de lucht te hangen.

Schaars zijn gepubliceerde uitlatingen van de derde "hoek" van de driehoek, de opdrachtgever. De onmondigheid van de bouwheer zal daar wel debet aan zijn. Stelt Th. H. oltheten, hoofddirekteur van het staatsdrukkerij-en

Uitgeverijbedrijf, niet; "Hij (de opdrachtgever) vraagt zich af warom men als model een driehoek heeft gekozen. Moet hij die driehoek zien als een analogon voor een

konstruktie, warin de architekt de sluitsteen plaatst, uiteraard op meerwerkrekening van de aannemer, en is hij, de opdrachtgever, dit sierstuk, een ornament als sluitgewelf?" en: ".... het heeft er de schijn van, dat er eerder vijf ondernemers gaan door het oog van de architektonische nald, dan één architekt door het oog van de ekonomische naald" (*42).

De rest van zijn betoog bevat veel verwijtenos aan het adres van de bouwmeester: geringschatting van de status van bouwheer, onzuiverheld in de relaties als gevolg van de honorariumregelingen, het drama der meerwerkrekeningen, ontbreken van duidelijke afspraken over kwaliteitsw begrippen. Het pijnlijke van deze ontboezeming was, dat oltheten juist het boumproces van zijn nleuwe vestiging had mogen afsluiten. Hij sprak dus uit ervaring.

Ir. A.J. van der steur zag wel degelijk de bedreiging van de architektenpositie in. zijn wisie was aldus: "ik meen, dat tegenover alle aansiagen op onze positie, die van de zijde van aan het onze grenzende beroepen worden gepleegd, en die beogen hetzij de architekt uit te schakelen of hem de toegang tot ons toekomende gebieden van aktie te ontzeggen, ofwel de architekt tot een meer ondergeschikte positie terug te aringen, zijn essentiële taak alleen kan worden verdedigd, wanneer wij kunnen warmaken, dat de architekt een specifieke taak heeft, waatcoe hij alleen op grond van zijn exklusieve potentie bevoegd is" (* 43). 
Terecht legde hij een duidelijk verband met de kwaliteit van de architektenopleiding alsmede het kulturele niveau van de opdrachtgever om de kwaliteit van de architektenprestatie naar warde te kunen schaten.

Hoe zag "de" architekt, of liever zijn bureau er in 1964 uit?

- het bureau war de medewerkers alleen werktekeningen make in

- het bureau war de architekt zelf ontwerpt en een grote invloed houdt op de detaillering. maar war toch op een gegeven ogenblik projektleiders voor het werk verantwoordelijk worden; gevaar van opsplitsing van het total in $k l e i n e$ eenheden

- het bureau met gescheiden ontwerp- en detailleringsafdelingen, soms ook cen uitvoeringsafdeling

- het bureau met projektmedewerkers, die zelf ontwerpen en die elkaar op coöperatieve basis bijstaan.

Ir. J. van santen halt de resultaten aan van een Engels onderzoek naar prestatieniveau, winst en produktiviteit van de verachillende bureautypen. Globale vergelijkingen laten zien dat central geleide bureaus voldoende ontwerp- en technisch niveau kombineren met een hoge winstgevendheid en produktiviteit. Buj de gedecentraliseerde bureaus gat een hoge standaard van ontwerp en technisch niveau gepaard met lage winst en produktiviteit, kleine bureaus, ca. 11 man, "doen" het slecht. Boven de 50 man komt de centrale leiding in gevaar (*44).

Hoewel Engelse en Nederlandse bureaus op zich verschillend zijn valt aan te nemen dat in grote lijnen de organisatievormen vergelijkbaar zijn.

Zoals te verwachten viel wordt in de tweede helft van de jaren zestig ook aandacht besteed aan de financieel ekonomilsche kant van het (groter) architektenbureau. In relatie met de honorarium-tabellen, tijdverantwoording, worden verrekensyatemen begproken en toegelicht. Het kan bevreemding wekken dat deze, voor een gezonde bedrijfsvoering onmisbare gegevens, nog gepropageerd moeten worden door organisatie-adviseurs.

De bouwexplosie heeft duidelijk kwaliteitsverlies van de (wonling) bouw tot gevolg. Dit is onderwerp van studie voor vier jaar de zgn. Bouwkundige contact commissie, die in 1962 verslag uitbrengt en tot de konklusie komt: "dat de architekten zich geheel anders dienen te gaan instellen, de annemers intern menselijker verhoudingen dienen na te streven en de gebruikers meer voor de gebouwen over moeten hebben". 


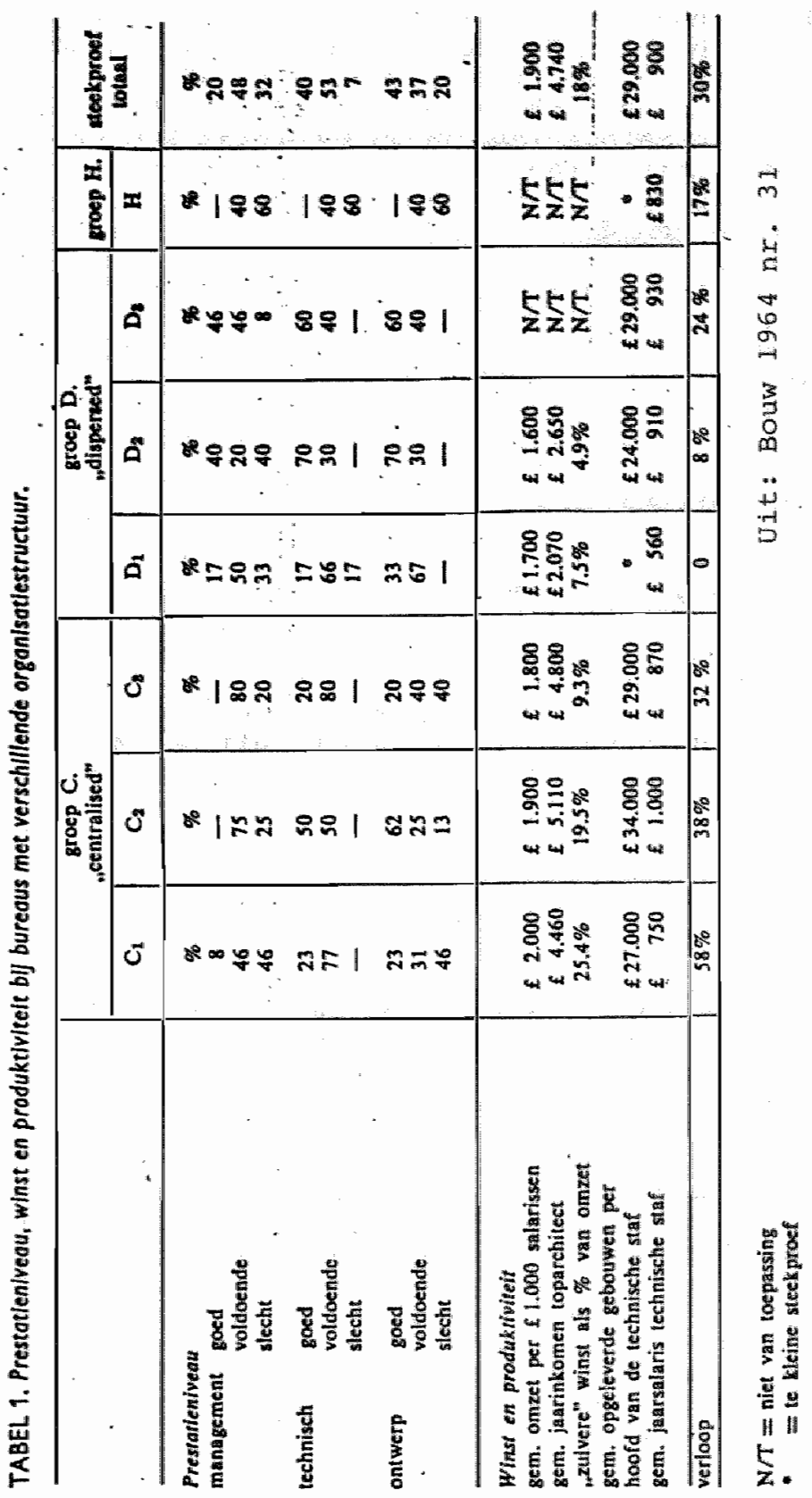


Gezien de algemeenheld wan de opmerking in de richting van de architekt zou hierbij de hoofdoorzaak moeten worden gezocht. Ir. P. Mulder analyseert warom (*45):

- de acceptatie van opdrachten met een z6 laag budget dat geen deugdelijke materialen en konstrukties kunnen worden toegepast, door het toegeven aan de pressie van opdrachtgevers tot een bezuiniging onder verantwoord niveau

- de onbekendheld van de architekt over de kwaliteit van door hem toegepaste materialen en konstrukties

- het tekortschieten van architekten op het punt van standardisatie, normalisatie, unificatie, mechanisatie, speurwerk, bouwfysika, kostenvraagstukken. onderhoudskwesties, dokumentatie enz.

- het bewust niet (kunnen) opvolgen van speurwerkadviezen omdat deze hogere investeringen vergt (tegenover een lagere exploitatie)

- onvoldoende kontrole op het werk door een te zuinig buaget voor toezicht.

Mulder verwijt de architekten gebrek aan solidariteit in hun weerstand tegen budgettaire druk die kwaliteitsondermijnend werkt, war deze toch door de erecode wordt geais. A. van Haaren (*46) stelt in zijn antwoord aan Mulder dat ex ook niet-ingeschrevenen zijn, die aan de regel niet gebonden zijn mar dat desalniettemin de vraag gewettigd is of "de architekt nog wel verplicht kan worden de volle verantwoordelijkheid te blijven dragen, met name wanneer het gat om door de overheid gesubsidieerde woningbouw" .

Toch blijven de architekten streven naar een goed produkt met op de toekomst gerichte elementen. In zijn openingswoord van de BNA-Experimentele Woningbouw Prijsuraag 1962, zegt ir. H. Lammers: "Architekten en stedebouwkundigen, geruggesteund door gelijkdenkenden, sociologen, artsen", psychologen, huisvrouwen, geestelijke verzorgers vormen de stuwende krachten die ononderbroken op de kwaliteit aansturen" (* 47). In zijn antwoord zegt drs. P.C.W.M. Bogaers, minister van volkshuisvesting, : "ik geloof namelijk dat met de strukturele reranderingen in de mat achappij en de etrukturele behoefte-stijging die darbij optreedt en die mede door massale geindustrialiseerde bouw mot worden opgevangen, een eveneens strukturele wijziging van de positie van de architekt gepard zal gaan...." en, "de aard van de opgave, de grotere schal, de verschuiving in de produktiemethoden betekenen echter wel veel voor de architekten ...." en, ".." hun funktie wordt dan die van de industrial designer...." (*48).

Het feit doet zich voor dat algemeen de gedachte postrat at de bouwproblemen via industralisatie zullen worden opgevangen, en dan wel industrialisatie in de zin van fabrieksmatige vervarariging van onderdelen die op de bouwplaats in elkar worden gezet. Een dergelijke ontwikkeling is echter nooit van de grond gekomen. Alle 
filosofieên over de positie van de architekt in dit industriële proces blijken dan ook geen stand te houden. sommigen zal dat niet hebben gespeten: In het pre-advies uitgebracht aan de Union Internationale des Architectes uit het najaar van 1964 heet het: "terwijl de integratie van de architekt in loondienst in de industrie enerzijds de praktische voordelen der concentratie biedt, houdt $z i j$ anderzijas het gevar in van een vermindering van zujn gezag ten detrimente van zijn matschappelijke coeping " $(* 49)$.

De ontwikkelingen zijn veeleer gegaan in de richting van bouwplatsgebonden systemen welke door de a annemerij werden gehanteerd en die werden ingepast in het architektenontwerp.

De echte industrièle woningbouw is geen lang leven beschoren, de fabriek van Dura-coignet sloot al snel har poorten.

Van belang voor de verhouding architekt-aannemer is nog een uiteenzetting van Twijnstra (*50) over de konfliktueuze siltuatie t.o.v. de kostprijsberekening van het bouwen. Zowel aan aannemerszijde (". feitelijk zou de aannemer... moeten beschikken over een uiterst goed calculatieapparaat") als aan architektenkant (". het beeld dat de architekt zich van de kosten vormt is op z'n zachtst gezegd nogal eens arbitrair.." wordt onnauweurig gewerkt, hetgeen, aldus Twijnstra, tot "koehandel" leidt. Refererend aan uniforme rekenmethodieken door onafhankelijke "quantity surveyors" welke in Engeland worden toegepast, konstateert hij dat voor deze ontwikkelingen bij de bouwpartners en ook hun officiële beroepsverenigingen, veel belangstelling bestaat.

Ergens anders schildert Twijnstra (*51) naast de architekt als creatieve kunstenaar een koele managerfiguur die met hem samenwerkt als professionele, special opgeleide" bouwleider. Een scheiding dus tussen vormgeving en bouwmanagement.

Het is opmerkelijk dat juist van de kant van de nietbouwers, nl. van de kinderarts Fiedeldij Dop, op een congres van de werkgemeenschap "Bergeljk", ( 52 ) een waarschwwing komt voor al te rationele benadering van de architektuur. Onder verwijzing nat o.a. le Corbuaider, Tange en Archigram benadrukt hij het belang van de door architekten opgezette stichting Architekten Research welke d.m.v. modulaire koốrdinatie de synthese vormt tusisen vormgever en industrieel bouwen.

Ir. W.F. Schut (minister van Wolkshuisvesting) schetst het tableau aldus: "maar die schakeringen in dat bouwwezen, die hier nu (Bouwdag 1968) wel broederlijk bijeen zijn, die echter als het straks weer op daden ankomt, meestal liefst eigen wegen gaan, die vele schakeringen zijn ook de zwakheid van het bouwwezen". Het antwoord daarop kon niet 
utblijven. Schut: "Er zijn verder reeds ontwikelingsmatschappijen die binnen het organisatorisch kader de vele belangen bijeen breriger, met inbegrip van de a anvangskosten en het latere profijt, die elkar kompenseren". Aldus signaleerde de minister de komst wan de projektontwikelate.

De "middelgrote" architekt heeft het inmiddells behoorlijk aruk: als ondernemer, niet als ontwerper, zoals blijkt uit de dagindeling zoals werkman (*52) die registreerde:

$\begin{array}{lrr} & \text { min. } & \\ \text { vergaderen buitenshuis } & 190 & 26,2 \\ \text { autorijden binnenshuis } & 160 & 22,2 \\ \text { vergaderen bit } & 80 & 11,1 \\ \text { thuis werken } & 80 & 11,0 \\ \text { komisies bijwonen } & 60 & 8,5 \\ \text { adminidtreren } & 50 & 7,0 \\ \text { tekenen } & 45 & 6,1 \\ \text { stafbespreking leiden } & 25 & 3,4 \\ \text { lunchen } & 20 & 3,1 \\ \text { stukken lezen } & 10 & 1,4 \\ & -720 & \frac{100}{100}\end{array}$

Werkman wekt op tot bezinning met een citat van Dante: "de hel, die het heetst is, is bestema voor diegenen, die in tijalen warin een morelle beslissing dringend nodig is, welgeren deze te nemen".

Niet alleen in ons land kampt de architekt met zijn rol.

Karl Brume, architekt in Duitsland wijst op de vervreending wan de architekt van zijn opdrachtgever en de verwrongen situatie die daardoor ontstaat vooral in de vertrouwensrelatie tot $z i j n$ bouwheer ( $\star 53$ ). Volgens hem heeft de architekt gekozen voor "de honorarium-zekere overeenkomst met de bouwondernemer".

of dat latute opgat voor nederlandse verhoudingen, valt niet te bewiljzen. Zeker is wel, dat de werkaruk van de architekt enerzijds en de verschuiving van de bouwwerantwoordelijkheid binnen de organisatie van de opdrachtgever naar meerderen in plats van één persoon (mondigheid) anderzijds, de persoonlijke relatie van bouwheer en architekt nar de achtergrond is gaan dringen. Daardoor treedt een verzakelijking op in de verhoudingen, die de architekt als vormgever geen goed heeft gedaan. Bij de bespreking van de volgende periode wordt daarop teruggekomen.

In 1968 wordt en bellangrijke vooruitgang geboekt in de uniforme kostprijsbepaling $\mathrm{d} . \mathrm{m} . \mathrm{v}$. de "Standaardmeetmeetmethode" "tot stand gekomen in samenwerking tussen aannemer 1 j en architekten. Cryptisch doet de opmerking van de voorzitter van de BNA an, die bij de introduktie stelt: 
"dat juist in de nieuwe ontwikkelingen (op de boumarkt F) de ontwerpvoorbereidingen $z i c h ~ z 6$ geheel anders ontplooien dan de aanemersbedrijvem, dat het overleg over de realisering tussen ontwerpers en technische volvoerders, zal toenemen" (*54).

Zelfkritiek is architekten niet vreemd. J.A. van den Berg schetst een beeld (* 55), en ziet het ontstaan van

"bouwbureaus van organisaties uit de landbouw,

kerkgenootschappen, bejaardenzorg, centrales van

woningbouwverenigingen, ontwikkelingsmatschappijen als ook in de vorm van organisatie bureaus en bouwteams,

geconnecteerd aan consurnentenverenigingen" als een gevolg van een gebrek an vakbekwamheid van de architekt en $z i j n$ personeel. De volledigheid van de architekt stoelt z.i. op drie zaken:

- neutraliteit ("kan licht leiden tot halsstarrigheid, frustratie en ontevredenheid)

- vakkennis ("eigen" verworvenheden van inzicht en kennis worden overschat)

- talent

Hij roept op tot taakverdeling "warbij ontwerper, coördinator en uitvoerend boumbedrijf een samenstel vormen, waruit op basis van onderscheiden disciplines wordt gebouwd aan één eindprodukt in planvorm", en "het invoegen van eigen kwaliteiten in super-bouwmatschappijen" " Een dergelijke tendens bestond ook reeds rond 1920 met de "HAGA-konstruktie" van ir. Gratama, (zie hoofdstuk III.6). De vraag is echter war nu de opdrachtgever sitad en hoe het gesteld zal zijn met de vertrouwensrelatie.

Twijnstra verwacht heil van schalvergroting van de architektenbureaus door fusies en doet naar de bereiaheid daartoe bij architekten een (beperkt) onderzoek. + 50 s blijkt vóór en $40 \%$ tegen, warruit zou kunnen blijken, dat velen twijfelen aan hun bestaansrecht en toekomst als kleine ondernemer. WeIlicht tekenend is dat Twijnstra filosofeert over het verdwijnen van het architektenberoep en het grote terreinverlies in de a an de gang $z i j n d e$ structurele ontwikkelingen. Zijn konklusie: "de harde, op economie steunende, westerse matschappij is niet langer bereid om alles wat de bouwmester voorschrijft voetstoots te accepteren" (*56).

Architekt Bekink (*57) konstateert, dat de grootte en de ingewikkeldheid van de opdrachten alsook de tendenties in het samenlevingspatroon grote problemen opleveren voor de middelgrote architektenbureaus. Al eerder zagen anderen dit type bureau geheel verdwijnen. Bekink ziet voor klein en middelgroot ook ekonomisch problemen ontstaan vanwege de diskontinuIteiten in het opdrachtenbestand. Waarom dit niet zou gelden voor het grote bureau is onduidelijk.

Ir. A.E.Q. van Hezik c.i., architekt, pleit in de richting 
Wan hereniging architekt-aannemer (*58) ook al onder druk van de grotere schal. Naar de opdrachtgever toe, acht hij het mogelijk dat de architekt in de ontwerpfase 100 a an de kant van de bouwers stat en in de uitvoeringsfase voor

loog an de kant van beleggers/opdrachtgevers. Aldus blijft de integriteit wan de onafhankelijk adviseur beward, redeneert van Hezik. Hoe dit kan bij een ondeelbaar boumproces, althans wat prijsstelling en rechtsverhouding betreft is alweer onduidelijk. De spreker ging zelfs zover om te suggereren dat "joint ventures" van architekten en annemera d.m. zakelijk belang in elkaars bedrijven mogelijk zouden moeten $z j j n$. Aldus is de cirkel rond, immers ook in de twintiger jaren konden deze geluiden worden vernomen. De "HAGA-konstruktie" van ir. Gratama komt ook hier weer tot leven (hoofdstuk III.6).

Dat middelgrote bureaus geen levenskansen (meer) zouden hebben was overigens een toekomstwilis. De realiteit in Duitsiand was dat over 1962,1964 en 1966 de bureaus met een jaaromzet tussen de 50.000 en 250.000 DM een forse groei doormakten $(* 59)$.

De architekt J.A. van den Berg, geeft in 1970 nogmaals een pessimistische kiljk op het wak (* 60). Hij refereert aan pagina's vol bouwfouten in tijaschriftpublikaties

loverigens zonder a an te tonen dat het ontwerp-fouten zijn). Ook hij voorziet. "een mogelijk verdwijnen van het vak". Hij hoopt op een "nieuwe" architekt, niet een "ondoordachte", geen matschappelijke achtergrona, geen integraalplan en a-ekonomische architekt, mar één die zich bezig houdt met de bijzonder persoonlijke interpretatie van milieu- en bouwprogramma's, die langs ontwerpmethodieken produceert en desgevraagd een garantie van funktioneel gebruik kan geven. Hij verzucht dat het lijkt of de tijd van "bouwer is dienen" voorbij is.

IV .2 .3

$1972-1985$ de architekt in een krisissituatie

De meest watachijnlijke oorzak van de na 1972 optredende krisisgituatie woor de architekt is het feit dat onder druk van de ekonomische recessie de rol van de architekt niet meer als vanzelfsprekend werd gezien. De toetsing van het verschuldigde honorarium an de daadwerkelijke resultaten viel uit in het nadeel van de boumeester. Wat tot dan toe als min of meer vanzelfsprekend werd geaccepteerd werd in het licht van de schijnwerper gezet, gewogen en te licht bevonden. Pas toen bleek hoeveel "meeliggers" de architekt in het bouwproces had gekregen. Als kreatief kunstenaar, vormgever, is men bereid de architekt te accepteren. Maar architektuur is een gebonden kunst en vormgeving is derhalve geen autonoom element in de bouwkunst.

Men kan stellen dat het tekortschieten van de opleidingen in de woorbereiding van de aspirant-architekt op zijn 
Het is jammer dat Kwant de projektontwikkelad in zijn betoog ten tonele voert, dat werkt verwarend: deze figuur stat immers buiten de beroepsgemeenschap. "Zorg voor zilchzelf" zou ik in dit werband wilen vertalen met "zorg voor het behoud van de eigen kreativiteit". Daarin verschilt ni. de architekt van andere vrije beroepsbeoefenaren.

Belangwekkend $z i j n$ de zeven stellingen die Kwant, aldus Van Ruler, poneerde op de Accountantsala in 1971 :

1. van een wrij beroep kan alleen sprake zijn wanneer er geen algemeem erkend recht is op de door het beroep geboden dienst; wanteer de dienst nog als een soort luxe wordt beschouwd. Het traditionele model van dienstverlening door beoefenaren van het vrije beroep gaat niet samen met het door de samenleving toegekende recht op thulp.

2. Kent de samenleving aan een ieder het recht toe op een soort dienst, dan moet een voorzieningensysteem worden gerealiseerd, wartoe iedereen toegang heeft (noot $F_{\text {. : }}$ daar heeft de architektengemeenschap zelf voor gezorgd: de architektenwinkels).

3. In deze sektor is geen sprake meer van honorarium in de traditionele zun, d.w. zi. van een ereloon, vastgesteld in vrije overeenkomst tussen geholpene en helper. Er is veeleer sprake van een soms keiharde tarievenstrijd, die wordt uitgevochten in de macro-samenleving. De individuele arts, jurist, architekt, profiteert van de resultaten van onderhandelingen die door vertegenwoordigers worden gevoerd.

4. De in groepsverband georganiseerde dienstverlenenden proberen hun service duur te houden. Het marxistisch model van klassestrijd is meer toepasbar in deze dan de vrije overeenkomst à deux.

5. De dienstverlenende enkelingen kunnen $z$ ich buiten de strijd houden omat de belangen in kollektief verband veilig $z i j n$ gesteld.

6. De kollektieve hardheid bij het bepalen wan de voorwarden van de dienstuerlening gaat vak samen met een hoogstaand persoonlijk ethos van de dienstverlenenden.

7. De vrijheid van de vrije beropen is soms meer een ideologische kreet dan een sociale werkelijkheid. Het is niet uitgesloten at men ook in gesalarieerd verband goede service verleent.

Natmate in deze paragraaf 1985 dichter wordt genaderd zal duidelijk worden hoe fundamenteel. Kwant's stellingen voor het architektenberoep zijn. 
Van Ruler releveert vervolgens een verhandeling van dr. A.L. Mok (*62) waaruit:

"wanneer a het traditionele professiemodel warde-orientaties en werwachtingen worden ontleend, die ontoereikend zijn voor de nieuwe professionele struktuur, zijn de gevolgen arieerlei:

- de professionals worden vanuit de matschappij en organisatie gekonfronteerd met verwachtingen wataan zij niet, of niet voldoende kunnen voldoen (motivationeel aspekt),

- er ontstat een dissensus over de in de beroepsuitoefening te realiseren warden (kulturele aspekten).

- de professionel struktuur in komplexe organisaties zowel als in het vrije beroep, is onvoldoende afgestemd op de nieuwe ontwlkkelingen (struktureel apekt). Voorts: "het is in het licht van het voorafgaande niet verwonderlijk, dat juist bij en ten aanzien van de traditionele professies de laatste tija een duidelijk gevoel van onbehagen bestat over het niet in staat zijn de matschappelijke veranderingen in oriëntaties en verwachtingen te verdisconteren. Oude gedragsnormen blijken ontoereikend te zijn om de dynamiek in de beroepsuitoefening te integreren, wardoor men in toenemende mate het gevoel heeft niet an de matschappelijke verwachtingen te kunnen voldoen. Traditionele beroepen als priester, huisarts, leraar, rechter e.d. zijn steeds meer an kritiek onderhevig."

Uit beide citaten blijkt dat de kern van de problematiek niet bij uitstek is voorbehouden an de architekten - ook kollega-vrije-beroepbeoefenars hebben er mee te maken. Het verschil met hen is echter dat er dar slechts sprake is van een apaningsweld tussen de beroepsgroep en de matschappij, terwijl de architekten door het ontbreken van een titel en of beroepsbescherming nog te maken krijgen met eer uitholilng van-binnen-uit. Men kan zich vrijelijk als alternatief-architekt afficheren en daarmee een konkurrentie oproepen die uiterst nadelig is voor de matschappelijke status, zowel in materieel als in ideologisch opzicht. Het is overigens nog de vraag of de architekten wel beseften niet aan matschappelijke verwachtingen te voldoen; de vaag kan ook omgekeerd $z i j n:$ de matschappij vindt dat we niet voldoen, zo ze uberhaupt "behoefte" an architekten hebben. Cannegieter merkt op (*63) dat de isuele milieubeheersing, waarbij architekten een rol moeten spelen, van alle milieuaspekten nog het minst duidelijk is. "Dat makt de funktie van de 
architekt in de samenleving bepald minder vanzelfsprekend dan die van arts, advokat, of accountant."

Hiermee is wel de kern blootgelegd van de veranderingen in de matschappelijke positie van de architekt. Beziet men de verantwoordelijkhejd van die beroepsgroep tegenover die matschappij dan hanteert men de Erecode als matstaf ten behoeve van de kwaliteitsgarantie voor het funktioneren in die matschappij. Deze Erecode, beroeps- of gedragsregels zijn verbonden met het tuchtrecht. Bij een behandeling van aspekten hiervan trekt Mr. Th.R. Bremer (* 64) parallelien met advokaten, medici, notarissen en accountants. Hij vestigt er de aandacht op "dat het bij architekten niet meer is dan een privaatrechtelijke regeling, opgezet door een aantal beroepsgenaten in verenigingsverband; en dat het géén regeling betreft bij of krachtens de wet." Wanneer Mr. A.A.M. van Agt dan ook een pre-advies formuleert voor de jaarvergadering van de Nederlandse Juristenvereniging aangaande het tuchtrecht in vertrouwensberoepen, gaat hij aan de beroepskode voor architekten voorbij - hij bepalt zich tot het van Statswege georganiseerde. De kritiek van Bremer beperkt zich niet tot de toen gangbare "wrij gedetailleerde" erekode, maar nog meer op het feit dat het Bestuur van de BNA de beroepskode wil vervangen door "Algemene Beginselen" (voorstel Van der Linden Plan 1/1971) bestaande uit een viertal algemene gedragslijnen. De bestaande regeling had een duidelijke analogie met arts, advokat of notaris, die thans dreigde te verwateren tot een algemene regel. Daarmee kwam, naar Bremers visie, het tuchtrecht op losse schroeven te staan, wardoor zowel de tuchtrechter als de architekt het houvast gaan missen. "De instruktieve en leidende warde van een beroepskode zou darmee komen te vervallen."

Kan het als symptomatisch worden gezien dat er behoefte werd gevoeld an een andere opzet en formulering van de Erecode? Zag men de bepalingen als te belemmerend voor de uitoefening van het beroep, of was juist het ongekeerde het geval?

Mocht er dan al van staatswege geen belangstelling bestaan voor de Erecode van architekten, hoe was het in begin 1970 gesteld met de bescherming van titel of beroep? Nadat het ontwerp van wet van 1949 in 1960 officieel werd ingetrokken (het had zelfa het atadium van "voorlopig verslag" niet mogen bereiken en onderging daarmee hetzelfde lot als het wetavoorstel van de BNA van 1957) benoemde de toenmalige miniter Schut eind zestiger jaren de zgn. "kommissie Kleijn" (*5) ter voorbereiding van een nieuwe wettelijke regeling. 
Minister schut verklaarde in zijn installatierede dat het tot dan toe onbeschernd zijn van het beroep zijn reden wond in het hoge peil van vakopleiding en beroepsuitoefening in Nederland en de hechte organibatie an overheidszijae "zomel door het samenstellen van bouwkundige voorschriften als door de grote zorg van de overheid voor het atedebouwkundig kader en de warborgen die in het welstandatoezicht zijn gelegen. "Voorts weet hil het uitblijuen van een wettelijke regeling a an het "ontbreken van een zekere overeensteming in de publieke opvattingen" tot dan toe.

De komissie kreeg tot taak een voorstel te doen tot titelbescherming, in verband met de in wording $z i j n d e$ EEG-richtiljn. Of de beroepsethiek en dus de tuchtrechtspraak al of niet deel zou moeten uitmaken van deze nieuwe regeling kende in de kommissie vóor en tegenstanders. Wóbr pleitte het integrale karakter van een wettelijke regeling, dus niet exklusief voor georganiseerden, terwijl een zodanige integrale administratief-wettelijke regeling ook een zwaardere rechtabasis zou verschaffen.

Tegenstanders vreesden een analogie met de kontroversiële beroepsbeschermingskwestie, men was immers vastbesloten deze kontroversen te vermijden. Voorts gewagt het rapport van de kommissie kleijn van het argument tegen een beroepscode:

"dat het ontbreken van gedragskriteria en de mogelijkheid om deze te formuleren rechtsonzekerheid scheppen", een analogon van Bremer"s gteling.

De voorstanders verwachtten in deze heil van de jurisprudentie. De tegenstanders duidden echter weer op de aandrang van gezaghebbende stemen om tot een integrale tuchtrechtspraak te komen voor alle vrije beroepen.

De kommisie kwam niet tot een eenstemmige aanbeveling, wel beval zij een wettelijk voorschrift tot het afleggen van de eed aan om "in woorkomende gevallen de strafrechter en de burgerlijke rechter een zekere steun te geven bij het formuleren wan zijn oordee 1".

In deze diskussie stat weliswar de gedragsethiek van de architekt centraal, maar wat betekent het becoep in matschappelijke zin?

De socioloog smeulers (* 66) schetst anno 1972 de architekt-beroepsbeoefenaar aldus:

- opererend vanuit een vaak onafhankelijk relatief klein bureau.

- Leidinggevend ontwerper/vormgever van in opdracht van anderen te (ver)bouwen ruimten. schepper van nar eigen inzicht mooie, 
funktionele en vaste ruimtelijke vormen en strukturen.

- Zich kreatief uitend door middel van tekenen als zijn meest wezenlijke taak.

Hij hoopt dat die taak in de toekomst meer zal worden:

- in dienstverband werkend.

- Opdrachten soms uitvoerend, soms medebepalend.

- Werkend als gekwalificeerde koördinator uit de midden- en eindfasen wan het

besluitvormingsproces, omdat daardoor nieuwe gebouwde ruimten resulteren en wardoor bestaande (gebouwde) omgevingen moeten veranderen.

- Het kreatief ongaan met andere betrokkenen in dit proces belangrijker zal worden dan het kreatief omgaan met materialen en vormen.

Het aktiviteitenpatroon van de architekt in de jaren 70 is afhankelijk van de bureau-omvang, zoals blijkt uit het overzicht dat is ontleend aan $J$. van santen $(* 67)$.

aktiviteit: $\quad 1-10$ pers. $11-30$ pers. 30 e.m.pers.

$\begin{array}{llll}\text { ontwerpen/tekenen } & 308 & 258 & 108 \\ \text { vergaderen } & 228 & 218 & 458 \\ \text { administratie } & 218 & 258 & 188\end{array}$

Een indikatie voor zijn matschappelijke positie volgt wit drie onderzoeken.

positie

zelfstandig

firmant, partner, dir.

in dienst van arch.bur.

medewerker

overheidsaienst

ondermijs

bouwbedrijf

overig bedrijfsleven

overig en kombinaties alle arch

\begin{tabular}{c}
548 \\
168 \\
98 \\
- \\
168 \\
- \\
- \\
58 \\
18 \\
\hline$A$
\end{tabular}

arch.reg. b.i.s

\begin{tabular}{cc}
518 & 428 \\
238 & - \\
108 & - \\
- & 178 \\
68 & 188 \\
- & 136 \\
- & 28 \\
28 & 48 \\
118 & 48 \\
\hline
\end{tabular}

Onderzoek A: Rac Marketing Nederland N.V. 1967

B: Architektenraad 1969

C: Studentenonderzoek 1971 .

voor de ontulkkelingen in de beroepspraktijk ziet smeulers als achtergrond de volgende matschappelijke processen:

- een toenemende arbeidswerdeling en specialibatie in de beroepstaken wardoor men meer en meer op 
cen beperkter en meer specifiek terrein werkzam moet zi jin.

- Professionalisering, d.w.z. de uitvoering van een specialistische taak na opleiding op akademisch niveau met als leidraad de gedragskode van beroepsgenoten.

- Rationalisering en verwetenschappelijking van beroepsstatus.

- Industrialisering en technologisering met de uiteindelijke noodzaak tot koördinatie gezien de daarmee gepard gaande hoge investeringen.

- Centralisering en integratie van besluitvorming met internationale tendenzen.

Deze matschappelijke ontwikkelingen hebben, nog steeds volgens smeulers tot 1972 de volgende konsekwenties gehad voor de beroepspraktijk van de architekt.

1. Aard van de bouwprojekten:

- Verschuiving wan individuele architektuur naar orngevingstechnologie.

- Groter en ingewikkelder projekten.

- Grotere opdrachtverscheidenheid.

- Flexibiliteit als programagegeven.

2. Betrokkenen bij de bouwprojekten:

- Het aantal betrokkenen groeit.

- Verschuiving van individuele opdrachtgever naar kommissies of organisaties.

- Scheiding tussen opdrachtgever en gebruiker.

- Toenemende gebruikerseisen.

- Overheidsregulering van de bouwproduktie.

- Vergaande regulering van het bouwproces door de overheid.

- Naast en tegenover de architekt verschijnen steeds meer gekwalificeerde deskundigen. technisch, ekonomisch en sociaal.

3. Realisatie van bouwwerken:

- Komst van een onoverzienbare variatie in bouwmaterialen.

- Prefabricage, normalisatie, standaardisatie.

- Veranderende konstruktiewijzen, mechanisering.

4. Positie architekt:

- Meer werknemer, minder ondernemer. Groei van de grotere bureaus.

- Horizontale integratie, verbreding van de samenwerking met andere adviseurs.

- Vertikale integratie, toenemende kans op voortdurende samenwerking met beslissers en. uitvoerders van wie men vroeger kontraktueel gescheiden was.

5. Aard van de architektenwerkzamheden:

- Meer programmeren en organiseren i.p.v. intuitief en impulsief handelen.

- Zoeken naar alternatieven en varianten i.p.v. het éne gave plan.

- Meer a andacht voor efficiëncy en kosten- 
beheersing teneinde een bepaalde kwaliteit voor een bepaalde prijs binnen een bepalde

levertijd te bieden.

- Sterker technisch en rationeel dan esthetischartistiek bepald zijn van bouwvormen en -strukturen.

- Grotere noodzaak van onderzoek en informatieverwerking.

- Meer toekomstgericht in plats van historisch bepald.

De reaktie van de beroepggemeenschap op deze te verwachten verandering was verdeeld, sommigen zien er positieve ontwikkelingen in, anderen worden beheerst door een "niet reeële angst voor aantasting van de zogenamae architektonische vrijheid" (*68). smeulers acht de volgende interpretaties van de architektentak problematisch worden:

- De edukatieve taak, de architekt als stimulator voor gedragsweranderingen van anderen.

- De wenselijkheid van territoriale sociabiliteit, de evolutie van de leefgemeenschap als sociaal element.

- Architektonisch determinisme, het bepalende van de gebouwde omgeving voor het menselijk gedrag.

- Het sociaal symbolisme als idee; de gebouwde omgeving is een weerspiegeling van de geest destijds en wordt door de beschouwers gelijkelijk als zodanig ervaren.

- Toekomstoriëntatie - de aandacht voor de veronderstelde toekomstwarde van het gebouwde boven de direkte gebruikswarde nu.

Volgens Smeulers zou de architektenpositie wel eens minder problematisch kunnen worden als hij, de architekt, meer inspraak en interdisciplinariteit zou toelaten, omdat dan pas zal blijken warin hijecht kompetent is met betrekking tot zijn werk.

Interessant is een onderzoek van sociologie-studenten naar een typologie van de architekt (*69) en vooral de wardering voor de negen hoofdaktiviteiten door de architekt zélf (zie blz.142)

Daaruit blijkt dat de gewenste en de feitelijke beroepsaktiviteit bijna nooit samenvallen. De architekt als gefrustreerde figuur? zelfs met inachtneming van de typologie kan dat bijna niet anders. 


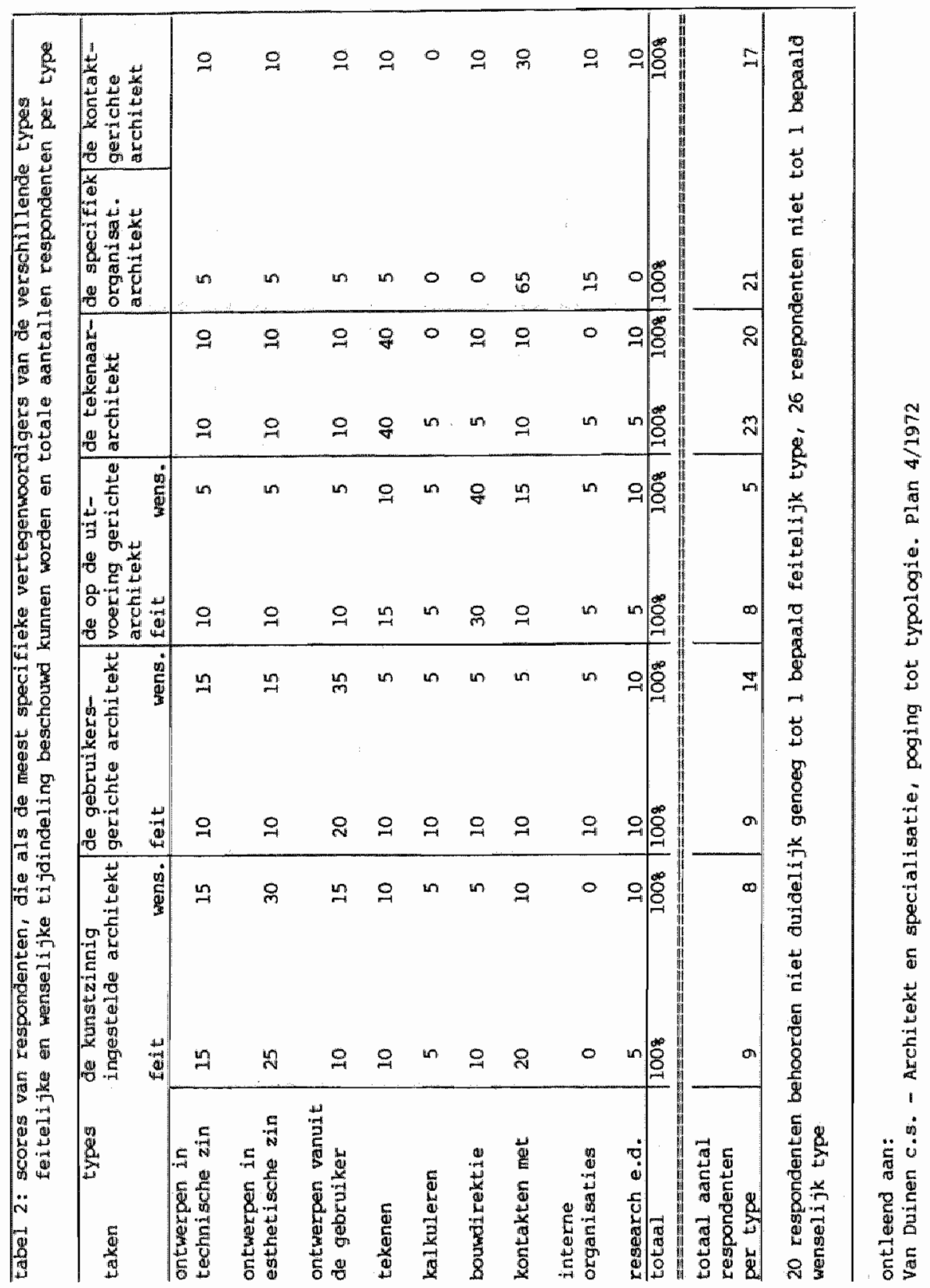


ook deze onderzoekers konkluderen dat specialisatie en samenwerking tussen gespecialiseerde bureaus de beste toekomstbeloften inhoudt.

Met de door de onderzoekers gedane aanbeveling dat de architekt de bewoner optimaal zal moeten bijstaan terwille van zijn eigen positie in het bouwproces, wordt echter voorbijgezien aan het feit dat opdrachtgever en bewoner geenszins synoniem zijn, er is zelfs sprake van tegengestelde belangen. Deze kontroverse blijft veelal niet zonder gevolgen. Deze zullen veelal neerkomen op het hoofd van de imspraaken bijstandverlenende architekt.

ook de rechtsworm van de architekt is aan verandering onderhevig.

De schalvergroting van somige architektenbureaus doet de behoefte ontstaan an steun in ekonomischjuridische zin (*70). Daarbij speelt de rechtsvorm van het bureau een grote rol. In deze tija zien wij dan ook de rechtspersoon van de B.V. ontstaan, warbij de architekt veelal direkteur/grootaandeelhouder is. De fiscale faciliteiten vormden de voornaamste drijfveer, alsook de sociale zekerheden voor de direktie. Aangezien de vrije verhandelbaarheid van aandelen voor de architekt niet speelt, komt de N.V. niet in a ammerking. Bovendien roept de veel verdergaande publikatie-plicht van deze rechtsvorm grote bezwaren op. De coöperatieve vereniging of de stichting is in relatie tot de rechtsvorm van het architektenbureau niet van betekenis geweest. In hoeverre de overgang van natuurlijk naar rechtspersoon invloed heeft gehad op de verhouding tot de opdrachtgever, is niet na te gaan, waarschijnlijk is die er niet. Het onpersoonlijker worden van de relatie is immers reeds begonnen bij de grotere opdrachtgevers als gevolg van de bedrijfsorganisatorische ontwikkelingen en de democratisering. Die onpersoonlijker verhouding van het architektenbureau is wel geaccentueerd door het aannemen van allerlei, voor de buitenstander onherkenbare initialen door vele bureaus. De drang hiertoe zal enerzijds zijn ontstaan uit een behoefte tot pseudo-commerciele affichering en anderzijds door een spreiding van de verantwoordelijkheid binnen het architektenbureau over meerderen dan alleen één architekt/eigenaar, een kollektiviteitsgedachte dus.

Niet alleer de rechtsvorm, ook de organisatorische aspekten krijgen grote aandacht. Alle facetten van commerciële funktie tot en met toekomstige ontwikkeling worden belicht in Kruyt en Twijngtra"s "Interne organisatie van het architektenbureau in Nederland" (*71). Uit onderzoek op 35 bureaus blijkt de verkoop van aantalien bureaus tussen 1960 en 1971 (zie bIz. 144 ). 


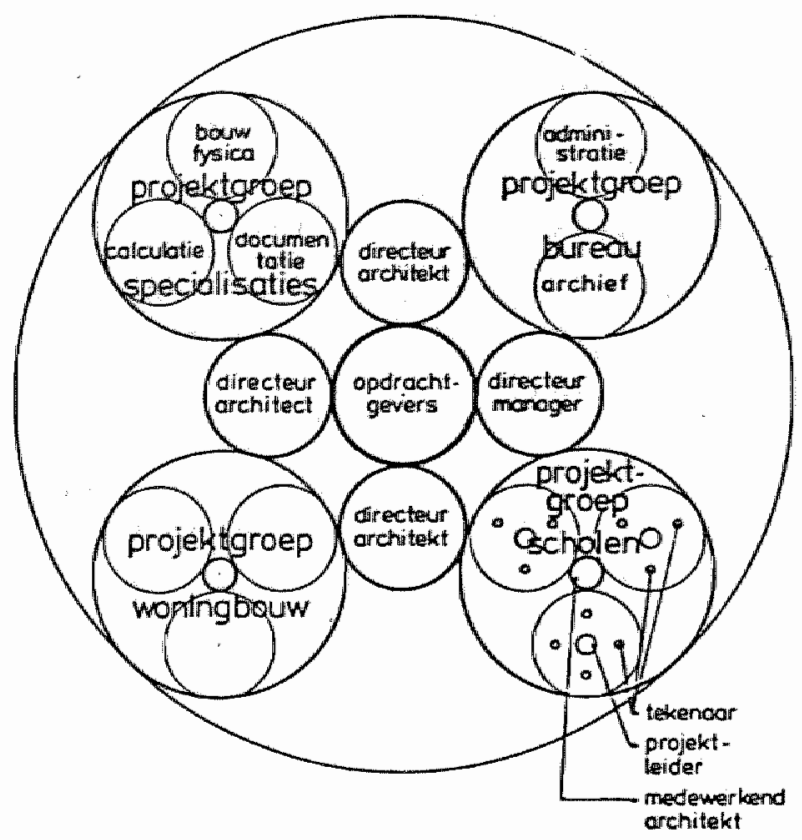

Een woorbeeld van en arganisatie. getekend als een radstructur.

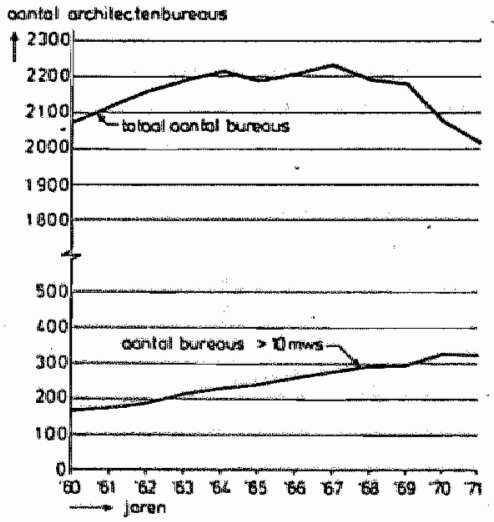

\author{
Uit: Twijnstra/Kruyt \\ De Interne organisatie \\ van het architektenbureau \\ in Nederland.
}

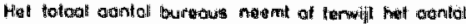

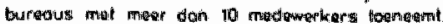


Voor de relatie met de opdrachtgevers is het schema ilustratief dat dataan eveneens is ontleend. Binnen thet bureau worden groepen specialisaties gevorma met raakvlakken op direktieniweau, in verschillende kategorieen, van direkteurfmanager tot direkteur/ architekt. Door de opsplitsing gat de eenduidige relatie van de architekt met de opdrachtgever vrijwel geheel verloren en wordt de ontwerpkarakteristiek pluriform en minder herkenbaar. De specifieke identiteit lost zich op (zie blz.142).

Dat er strukturele veranderingen op til waren in de bouwnijverheid als geheel voorzag ook Twijnstra al in 1973. De niet zeer gunstige konjunkturele ontwikkelingen stimuleerden een kritische instelling t.a.v. de struktuur van de bouwnijverheid. Hij

signaleerde de volgende veranderingen:

- het karakter van de vraag. Na 1968 is de vraag naar eigen bedrijfsgebouwen niet toegenomen. Er is een relatieve stijging van het bouwen voor de markt:

- de vorm warin de vraag op de markt kont. Door de sterkere positie van de opdrachtgever, samenhangend met een grotere deskundigheid van deze inzake de bouwmarkt, verandert ook zijn attitude:

- het karakter van het aanbod.

Een deel van de dienstencapaciteit verschuit van het ontwerpend en adviserend nat het producerend en uitvoerend bouwbedrijf.

Dat laatste is vooral van belang voor de adviseur en de architekt.

"Hun positie zal in elk geval moeten worden bepaald door hun deskundigheid, hun integriteit en óbk door de ekonomie van thun werk, die men steeds meer zal gaan zien als een facet ván de deskundigheid". (*72)

De situering van de architekt in de matschappijen de relatie met de $\mathbb{P}$ itelwet wordt in 1973 indringend belicht door interviews met vertegenwoordigers uit ae bouwkundige disciplines $(* 73)$. Dit naar a anleiding van een publikatie in cobouw van 20.4 .73 wan een summiere samenvating van het nieuwe wetsontwerp "Bescherming Architektentitel".

Aannemer 1 .

"Ik geloof dat het architektschap meer te maken heeft met een heleboel faktoren meer dan alleen maar goed kunnen tekenen, maar die andere argumenten die daar bij gesleept worden, betrouwbarheid en $z o$, dat vind ik gewoon een belediging voor mij en mijn kollega's."

Aannemer 2. (Mede nat a nleiding van het BNA Wetsontwerp van 1957). 
"Ja, eigenlijk had dat (weerstand bij aannemers) voor het bouwbedrije dezelfde achtergrond; het hier vrij zijn on architektuur te bedrijven en zelfstandig bepalide zaken af te wikkelen. We zitten vandaag-de- dag helemad in de turn-key projekten en in de ontwikkeling van grote objekten, warbij men tot totale aanbiedingen komt. In die totale arabieding past een stuk architektenwerk, financiering en al datgene wat nodig is om tot een totaliprojekt te komen. En dat was dus in ait wetsvoorstel niet mogelijk."

Dit laatste is niet juist, het wetsontwerp verbood geen samenwerking tussen architekt en aannemer. Bovendien gat het hier niet om een beroepsbescherming mar om titelbescherming.

Aannemer $\mathbb{L}$.

Wat heeft 1 edereen die met bouwen te maken heeft, dat is dus vanzelf iedere Nederlander, voor belang bij titelbescherming?... " dan kan het bouwbedrijf ontwerpen onder eigen verantwoordelijkheid indienen voor een bouwvergunning, ontworpen door een architekt in eigen dienst."

Aannemer 2 .

"...mar alles is te koop, dus ook architekten, dat waren ze al en ook nu blijven ze het. Natuurlijk, als de spoeling dunner wordt is alles durder, dat is altija zo, met betonijzer en met architekten, maar te koop is alles."

De ontwikkelingen voltrekken zich niet zonder zorg voor de feitelijke taak van de architekt in Eilosofische' zin: "in binnen- en buitenland, want het verschijnsel was algemeen, ontstonden "projekten" en de architekt met verruimde visie werd een algemeen aanvarde plaag. De wereld welke om ons heen tegenwoordig wordt opgebouwd is er een die grotendeels wordt vervardigd door architekten wier visie net zoveel te groot is alg die van de meeste aannemers te klein. Hun ontwerpen dienen de architekt, zoals de knutselpartijen van een aannemer, de annemer plegen te dienen. Wat er telkens weer tussenuit valt is de nens zélve", klaagt Joost de Klerk $(* 74)$.

Faszbinder relateert de funktie van de architekt a an produktiesystemen. In dat licht acht zij het

kennisniveau van de architekt te generalistisch (* 75). De komplexiteit van de werkzaamheden van de architekt, die bestaan uit een veelheid van heterogene deelfunkties, sluit hars inziens an bij een periode warin de arbeid als matschappelijke produktiekracht nog niet volledig is ontplooid in 
samenhang met de mate van kapitaalskoncentratie en de geringe mate van arbeidsverdeling. Zij voorziet een differentiatie van de architektentaak in een aantal aparte funkties in de produktie en toezicht, en een verdwijning van het beroep, in vergelijking met de handwerksman uit vroeger eewwen. zij. kenmerkt het becoep van architekt als een "ongedifferentieerd mengsel van irrationalisme, idealistische dromerijen een hulpeloos ad hoc a anpassen aan wat de arbeidsmarkt vraagt".

Haar opmerkingen over de verandering van bouwen voor de markt in plats van voor de gebruiker zijn naar mijn mening steekhoudend. Niet de gebruikswarde van het produkt, dus de gerichtheid op de individuele beleving, is in veel gevallen primair, mar de marktwairde. De opkomst van de projektontwikkelaar heeft dit facet veroorzaakt, en gezien het belang en de afhankelijkheid voor en van de architekt schart deze zich aan een zijde war andere kriteria gelden, die niet specifiek des architekts zijn. Dat houdt zeker een degradatie in van zijn kulturele funktie.

Faszbinder konkludeert dat een verschuiving wan werkzamheden van de architekt naar de organisatie van grote opdrachtgevers zal gaan platsvinden. Dat is ten dele ook gebeurd, zij het om andere dan arbeidsfilosofische redenen. De voorspelling van het ontstaan van Mammot-bureaus "war een leger loonafhankelijke architekten ${ }^{\text {"t }}$ zwoegt onder een bas "die zijn onafhankelijkheid heeft weten te redden" is achterhaald door de ekonomische recessie. Daardoor is het ontwerpprocédé ook min of meer in stand gebleven "warin de architekt, de behoeften van gebruikers aanvoelend, zichzelf uitroept tot katalysator, om op deze wijze ongevraagd zijn eigen klasse-vooroordelen, voorzien van een passend omhulsel, op de matschappij toe te passen".

Het belang van het goed funktioneren van de architekt binnen de matschappij in relatie tot het bouwen is, zij het uit een andere zienswijze, ook belicht door prof. dr. I. Hamaker (* 76). Hij citeert G. Werkman (*77)

"De bouwnijverheid is geen doel op zichzelf mar een middel, dat een heel ander doel. dient. namelijk het funktioneren van de gehele matschappij".

Hamaker vindt de architektentaak te veelomvattend om goed uitgevoerd te kunnen worden en verwijst naar kritiek die stelt dat de architekt de technische en managementrevolutie niet heeft kunnen bijhouden (* 78). Om die reden ontstaan naar zijn inzicht een Informatie Centrum Scholenbouw, Institut voor ziekenhuisbouw en "tot op zekere hoogte de 
Rijksgebouwendienst"

Een koncentratie door de architekt op het matschappelijk initiatief tot bouwen lijkt hem gewenst, en hij ziet hem als bruggehoofd in de weg van initiatief nar (bouw) aktiviteit. Dat impliceect een participatie in de programmafase, vanuit de gebruiker. In een door hem angehaald voorbeeld van revolutionatr bouwen (*79) in de onderwijssfeer zijn de ontwerpers a an de aktieve zijde gaan staan, zonder zich te verdiepen in gebruiksbeperkingen buiten de direkte schoolfunktie. Het betrof hier namelijk een multifunktioneel komplex, met naast de schoolfunktie, nog andere matschappelijke aktiviteiten. Dit leidde in het praktisch gebruik tat grote problemen. Men kan zich echter afuragen of dat, zeker in dit geval, wel tot de taak van de architekt behoorde. Daarmee is het probleem geschetst van de éénzijaige oriëntatie van de architekt op de opdrachtgever, wardoor andere matschappelijke belangen in de knel kunnen komen. Dat is helaas vaak het dilemma van de architekt.

Zo is de positie van de architekt in het mat schappelijk en sociaal krachtenspel nog immer in diskussie. De ekonomische basis van zijn funktioneren is bovendien opnieuw allerminst gezond.

Chlcanes, of nalatigheden, ten aanzien van

betalingstermijnen door opdrachtgevers voor het architektenwerk $z i j n$ schering en inslag. De bureaucratische aard van vooral ambtelijke opdrachtgevers vertraagt de betaling zeer. Architekten arzelen ook te lang met het verzenden van aanmaningen, op dat punt zijn ze niet met de trend meegegroeid. De gemidaelde termijn van uitstaande vorderingen is per ultimo boekjaar $5-5,5$ maand van de orzet. Toch is dat slechts één oorzaak van het doar Kiers (* 80 ) gesignaleerde te lage gemiddelde rendement van het architektenbureau $(* 81)$. De vermogensverdeling is over de samenwerkende Atchitekten bureaus (SAB) als volgt:

debiteuren $40-50 \%$

onderhoudswerk $20-25$ *

vaste activa etc. $10-15 \%$

De vereiste investering per werknemer bedroeg in de jaren 170 f. $80.000,-$ à f. $90.000,-$ aan totaal

vermogen.

Aangezien een architekt hoofdzakelljk arbeid levert dient de vermogenspositie gerelateerd te worden aan de otijging van de arbeidskosten. Het gemiddeld rendement van de bureaus is darvoor niet toereikend, aldus kiers.

Van binnenuit het becoepsvela is er bovendien nog de kritiek wan opportunisme inzake de achillespees van de architekt: de architektonische vorm, Rijksbouwmeester Quist over de "onzekerheid over de 


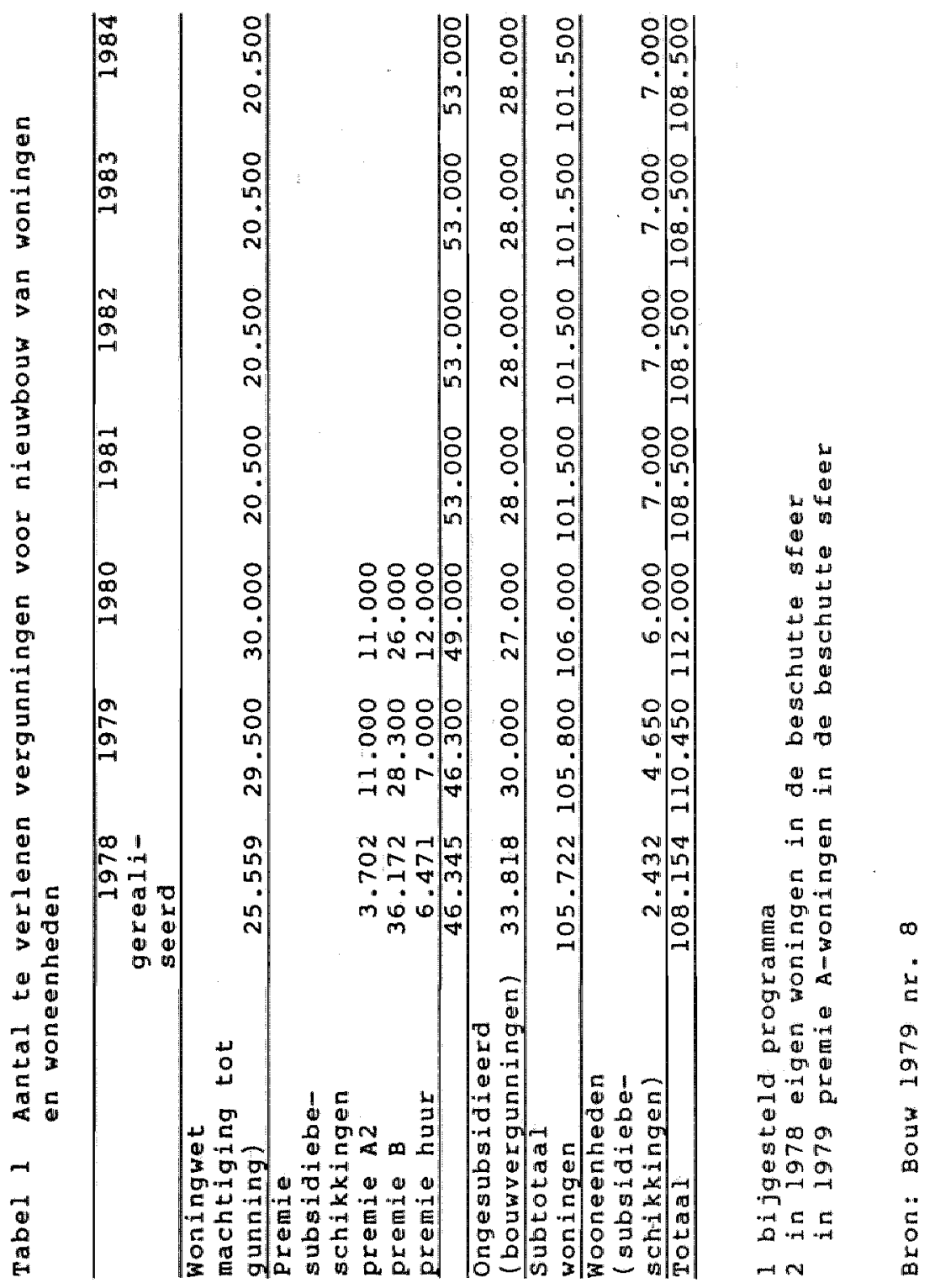




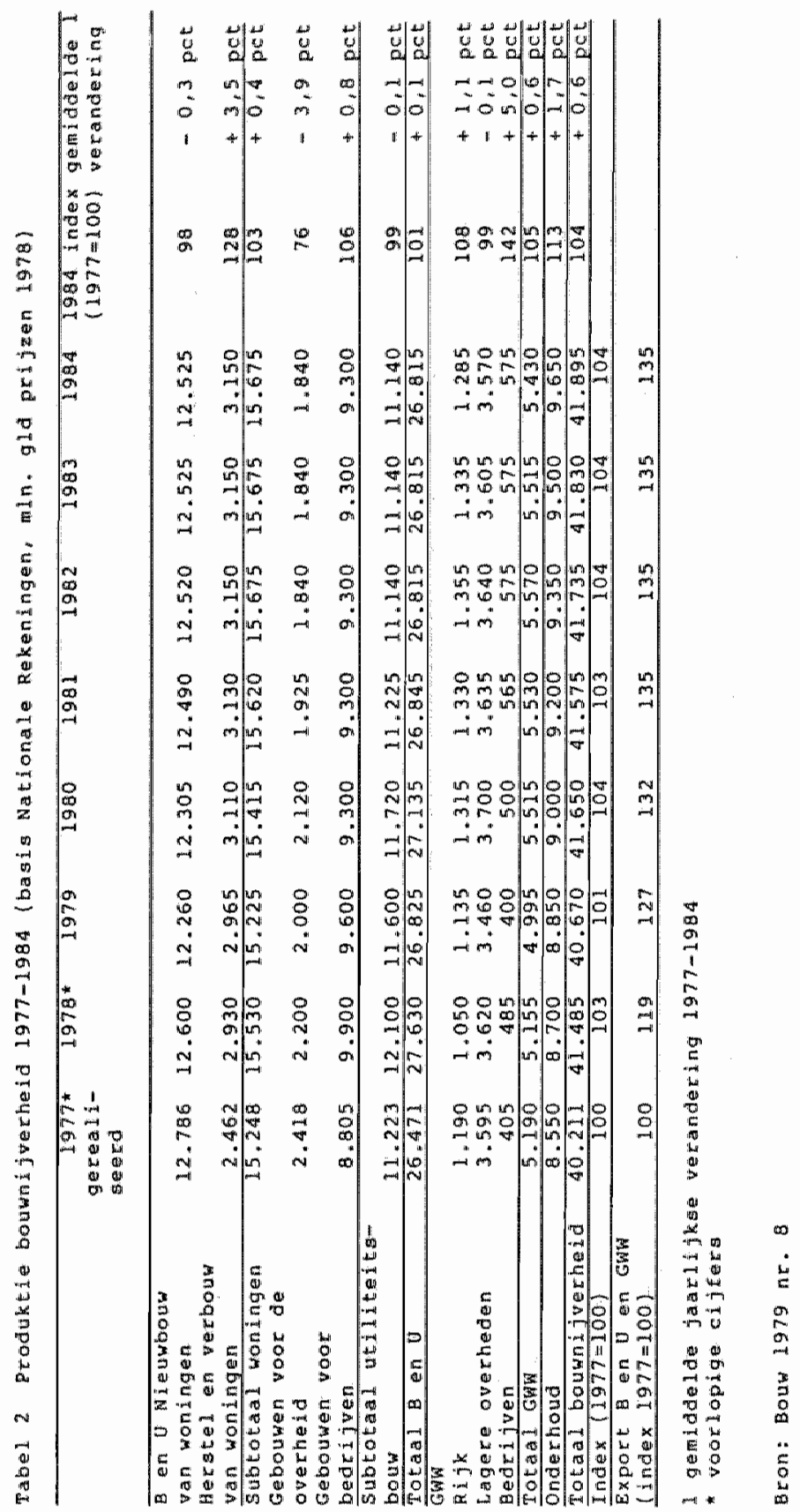


Tabel 1 Resultatenberekening (51 bureaus) ( $x$ f $1.000,-)$

\begin{tabular}{|c|c|c|c|c|}
\hline & gemi & Id & & \\
\hline & 1974 & & 1976 & \\
\hline & & pct. & & pet. \\
\hline Direkte kasten & 505 & 64,6 & 641 & 66,6 \\
\hline Indirekte kosten & 182 & 23,3 & 211 & 21,9 \\
\hline Betaalde rente & 20 & 2,5 & 16 & 1,6 \\
\hline Ontvangen rente & - & $-0,9$ & - & $-0,6$ \\
\hline Diverse baten en lasten & 8 & 1,0 & 29 & 3,0 \\
\hline Totale kosten & $70 \overline{8}$ & 90,5 & 891 & 92,5 \\
\hline Winst vóár belasting & 74 & 9,5 & 72 & 7,5 \\
\hline Omzet (exk1. BTW opzichters & & & & \\
\hline en verschotten) & 782 & 100,0 & 963 & 100,0 \\
\hline
\end{tabular}

Tabel 2 Analyse omzet en resultaten (51) bureaus in 1976 (in $1.000,-$ per gemiddeld bureaw)

$\begin{array}{llllll}\text { omzet } & \text { resul- } & \text { kost- } & \text { norma- } & \text { rende- idem } \\ \text { taat } & \text { prijs } & \text { tief } & \text { ment } & \text { in pet } \\ & & & \text { mente- } & \text { tekort van } \\ & & & \text { omzet }\end{array}$

\begin{tabular}{|c|c|c|c|c|c|c|}
\hline $\begin{array}{l}\text { AR hon. } \\
\text { tabel } \\
\text { werktek. } \\
\text { (uurtarief) } \\
\text { overig uur- } \\
\text { tarief }\end{array}$ & $\begin{array}{r}549 \\
87 \\
67 \\
39\end{array}$ & $\begin{array}{r}69.2 \\
-\quad 14.7 \\
9.0 \\
5.2\end{array}$ & $\begin{array}{r}479,8 \\
101,7 \\
58,0 \\
33,8\end{array}$ & $\begin{array}{c}99,9 \\
- \\
12,1 \\
7,0\end{array}$ & $\begin{array}{r}30,7 \\
14,7 \\
3,1 \\
1,8\end{array}$ & $\begin{array}{r}6 \\
17 \\
5\end{array}$ \\
\hline $\begin{array}{l}\text { RT hon. } \\
\text { tabel } \\
\text { prix fixe }\end{array}$ & $\begin{array}{r}164 \\
19\end{array}$ & $\begin{array}{l}0,5 \\
2,5\end{array}$ & $\begin{array}{r}163,5 \\
16,5\end{array}$ & $\begin{array}{r}34,1 \\
3,4\end{array}$ & $\begin{array}{r}33,6 \\
0,9\end{array}$ & $\begin{array}{r}21 \\
5\end{array}$ \\
\hline $\begin{array}{l}8 \text { pet } \\
\text { regeling } \\
\text { RR }\end{array}$ & $\frac{19}{19}$ & $\begin{array}{r}3,6 \\
-1,8 \\
73,5\end{array}$ & $\begin{array}{r}15,4 \\
20,8 \\
889,5\end{array}$ & $\begin{array}{r}3,2 \\
4,3 \\
164,0\end{array}$ & $\begin{array}{r}-0,4 \\
6,1 \\
90,5\end{array}$ & $\begin{array}{r}-2 \\
32 \\
10\end{array}$ \\
\hline
\end{tabular}

Uit: Bouw 1979 nr. 7 
warde van de architektonische vorm" (* 82$)$ : de architekten stellen zich te passief op, met een hang natr nostalgie in de vormgeving. Zij geven teveel gehoor "alan wat de samenleving wenst". Deze samenleving (i.C. de opdrachtgevers) lat zich meer leiden "door een terugverlangen naar vroegere zekerheden dan dat $z i j$ bezig zijn met een kritiach onderzoeken naar eigen mogelijkheden en grenzen"t. Bij het antwoord op de woningnood van na de oorlog zijn de ontwerpers aan de kant blijwen staan, zij zijner, aldus quist, ook niet voldoende bij betrokken, zie Hoofdstuk IV.2.1.1. Hoewel zijn verwijt ook architekten betreft signaleert hij ook een leemte aan opdrachtgevers met visie.

Drs. A.W.F.J. Bakermans (* 83) schat in dat eerst de jaren ná 1990 het zwartepunt te zien zullen geven van de zich nu manifesterende, dalende, tendens. Hij voorspelde dat in 1982 de omvang en samenstelling van de bouwproduktie vrijwel zou overeenkomen met de situatie van 1978 , en dat zelfs tot 1990 weinig strukturele veranderingen behoeven te worden verwacht. De accentverschuivingen zullen zijns insziens liggen op "differentiatie, kwaliteit en woonkomfort." Prof. dr. A. Hendriks visie is al evenmin rooskleurig. Hiervoor zij verwezen naar hoofdstuk IV. 1 .

Het zal duidelijk $z$ ijn hoe moeilijk het voor de architekt is anticiperend te reageren op een markt warop ook de ekonomische deskundigen geen eenduidige visie kunnen ontwikkelen. Zijn positie is bovendien athankelijk van de wijze warop de vraag-en anbodzijde van de markt zijn gestruktureerd.

De officiële verwachtingen geven echter in 1978 nog geen sterke terugval te zien, toch verwachtte minister Beelaerts van Blokland een terugloop in de bouwijverheid van 2500 arbeidsplatsen, deels terug te voeren op produktiviteitsstijging (per man). De feitelijke achteruitgang zou pas rond 1981 een feit zijn (*84).

Midden 1979 wordt opnieuw overleg geopend tussen de $B N A$ en het Ministerie van Economische zaken inzake de achterblijvende rendementsontwikkeling van de architektenbureaus. De grootste achterstand bestond bij de woningbouwopdrachten en de restauratie (* 85 ).

Mulder (* 86) wijst ex overigens op dat de ontwikkeling naar gevarieerd en pluriform bouwen in de woningbouw mede te danken is aan de inzet van ontwerpets, een inzet die tegen hun financiële belang ingat ondat de honoraria zijn afgestema op de grootschalige bouw. Eveneens in 1980 blijkt opnieuw, 
nu uit een rapport van de stichting voor Economisch onderzoek van de Universiteit wan Amsterdam, dat het gemiddelde honorarium voor architekten-werkzamheden in 1977 ongeveer 5\% bedroeg van de bouwsom, hetgeen lager is dan de gangbare BNA-regeling (* 87). Bij toepassing van de AR'71 zou dit poor de allerkleinste opdrachten het dubbele moeten zijn. Wanneer de woningbouw buiten beschouwing wordt gelaten stijgt het gemiddelde honorarium toch nog slechts naar. $6 \%$. Het gemidalde bruto-jaarsalaris van de werknemers, inklusief de direkteuren van BV"s, bedroeg bij de grotere bureaus f. $50.000, \ldots$.

In 1981 rapporteerde de BNA dat eind van dat jaar het antal arbeidsplaatsen op de bureaus, vergeleken met januari 1980 met 208 gedaald zou zijn, hetgeen aanleiding was voor een gesprek met de toenmalige minister. Deze deelde het pessimisme niet, er zou minder sprake zijn van achteruitgang dan de BNA suggereerde. Op gerichte steunmatregelen ter overleving van het beroep hoefde dan ook niet gerekend te worden.

Gert Jonker (* 88 ) stelt dat de architektenstand door steeds wisselend beleid dirigistisch is behandeld. Het bevorderen enerzijds en afremmen anderzijds van de bouw door de opeenvolgende regeringen, die bovendien als opdrachtgever optraden, heeft de kontinuiteit van de bureaus $z$ waar op de proef gesteld. Het politieke gewicht van de architekten als kleine werkgevers was bovendien voor niemand van enig belang. Hij wijst erop dat juist in een tijd van "Selbst-gesundung" er een wezenlijke behoefte zal zijn aan architektonisch kunnen.

In Europees verband blijkt Nederland er ongunstiger voor te staan qua bouwproduktie dan de rest van het kontinent (* 89). De bouwnijuerheid in ons land ook slechter dan de overige sektoren van het

bedrijgleven.

Naarmate 1981 vordert wordt steeds duidelijker hoe zeer de bouwsituatie verslechtert (* 90). Bovendien tekent de vraag $z i c h$ af of er geen sprake is van strukturele problemen in plaats van konjunkturele. Uit het beeld van vroegere golfbewegingen leidt

Ter Hennepe af dat "de huidige inzinking in 1983 ten einde zal zijn". Als redenen voor de slechte situatie op de bouwmarkt worden aangevoerd:

- stijging van de gemiddelde stichtingskosten (grondprijzen)

- idem van de bouwkosten

- stijging van de rente

- stagnatie in de groei van de persoonlijke in komens 
- stijging kosteri levensonderhoud (energie) Vootalsnog wordt door Dr. A.G. ter Hennepe in de jubileumuitgave van het EIB gesteld dat op dat moment nog geen sprake is van een verzadiging van de bouwbehoefte.

In deze ekonomisch wankele situatie verandert de marktsituatie voor het bouwbedrijf door van vraag naar a anbod te verschuiven.

Reeds in het verleden is duidelijk geworden dat de anbodzifde van de bouwijuerheid, de aannemerij, juridisch in een ongelijke positie verkeert. Dit verschil is echter door de hoogkonjunktuur, en de daarmee gepard gáande komfortabele onderhandelingspostie a an a anemerszijde, nauwelijks effektief nadelig geweest.

Nu echter verandert dat, omdat een meedogenloze konkurrentie zijn intrede dreigt te doen.

Van belang is daarom te vermelden dat sinds 1971 door de Commissie Economische Mededinging gestudeerd wordt op de noodzakelijkheid van a anpassingen van de a anbestedingsregelingen. De commissie brengt in 1975 advies uit aan de Minister en stelt onder meer: "de aanbesteding schept een marktsituatie die belangrijk afwijkt van de omstandigheden waronder vraag en aanbod elkar op markten plegen te ontmoeten. Met de specifieke vraagtechniek van de aambesteding vindt geen konkurrentie over en weer plaats tussen een aantal aanbieders en vragers, waarvan een zeker evenwicht in de marktverhoudingen zou mogen worden verwacht. Door de a anbesteding stat de opdrachtgever in de unieke positie van één enkele vrager van een in beginsel niet substantieel goed, wartegenover aan de aanbodzijde zich een hoeveel heid gegadigden aandient, die in onderlinge konkurrentie nat gunning van een werk dingen. In deze situatie geniet de opdrachtgever een belangrijk marktoverwicht en neemt de individuele inschrijuer, aangenomen dat tussen gegadigden geen kontakt plaatsvindt, als werkpartij een bepald $z$ wakke positie in. (Advies CEM a an Minister Economische zaken d.d. 01-12-1975).

Het adviseren an de Minister leidae op 20 juli 1979 tot het instellen van de Overleggroep

"Ordeningsthema's Aanbestedingswezen" met als taak advisering en bestudering van o.a.:

- de techniek van de vraag

- regulering van het aanbod

- de verbetering van de gegevens welke bepalend zijn voor de inhoud van de aannemingsovereenkomst. 

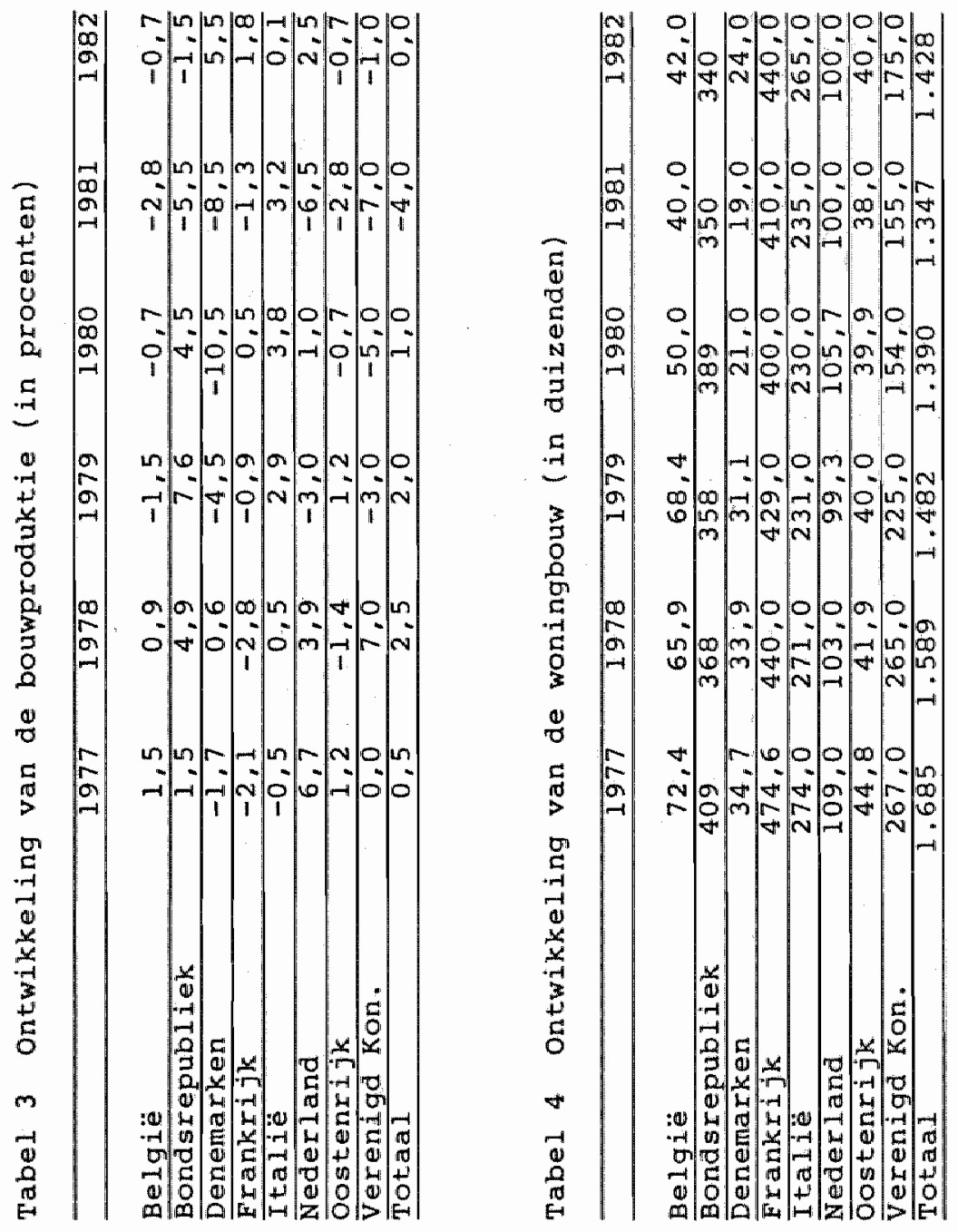

0
0
0
0
0
0
0
0
0
0
0
0
0
0
0
0
0
0 
Aan dit overleg werd deelgenomen door alle deelnemersgroepen aan het bouwproces en de Rijksoverheid. Het eindrapport werd uitgebracht op 23 juni 1982. Eerst in 1985 werd bij de herziening van de UAR gebruik gemaakt van het rapport, namelijk om er enige artikelen in het rijkskoncept-UAR mee te herredigeren.

Wanneer het rapport integraal kan worden gebruikt on als leidraad te dienen bij de herziening van UAR en UAV kan elindelijk een einde komen aan een rechtsongelijkheid die in beginsel al sinds het ontsan van de aanmemerij heeft bestaan.

Het EIB verwacht in 1982 een hogere bouwproduktie dan een jaar eerder was voorzien (*91), maar verwacht daarna een daling. Het verschil in zienswijze van BNA-architekten en EIB zit waarschijnlijk in het feit dat de EIB-cijfers betrekking hebben op uitgevoerde bouwwerken, terwijl de architekten daarin $\# 2$ jaar vóóclopen omdat $z i j$ denken in ontvangen opd̄rachten. Opmerkelijk is dat in de vakpers de dreigende ondergang van de architekten door niemand wordt gesignaleerd, het enige wat kenbaar wordt $z i j n$ cijfers en voorspelilingen, mat aan de. matachappelijke implicaties van het wegvallen van kultuurbeoefenaren wijt niemand enige aandacht. In 1981 belegt de $K M B B / B N A$ een bijeenkomst rond het thema: "De gebouwde omgeving in de jaren tachtig". Prof. dr. ir.H. Priemus en drs. A. Buur voeren daar voar de recesisie de volgende oorzaken aan:

- budgettaire problemen voor de overheid

- hoge rente op de kapitaalmarkt

- dalende koopkracht

- stijgende energiekosten

- ongunstige resultaten van het bedrijfsleven

\section{Zij ontwikkelen twee scenario's:}

1 ekonomisch herstel kan worden verwacht. Deze verwachting is gebaseerd op de (al vaker gesignaleerde) golfbeweging in de ekonomie, na een dal komt toch weer een top.

2 een trendbreuk in ekonomische groei, met als gevolg dat een kwaliteitsverbetering en uitbreiding van het produktievolume niet meer kunnen worden gef inancierd. 


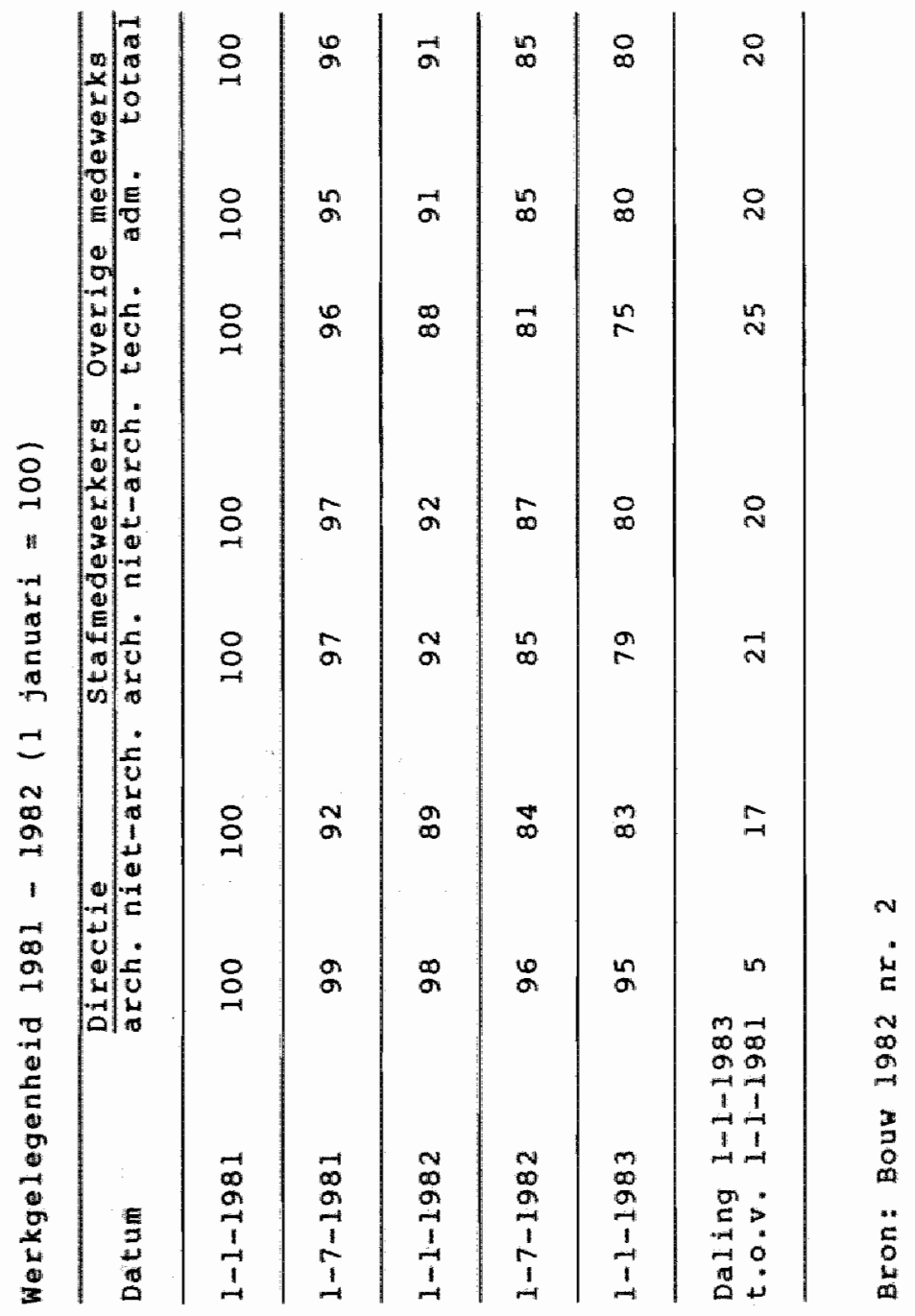


De onzekerheid welk scenario uiteindelijk vorm $z a l$ krijgen wordt fundamenteel geacht.

De enquête BNA van april 1982 geeft voor de architekten weer sombere cijfers te zien, meer leden nog dan anders verwachten een neergang. De werkgelegenheid is in drie jaar tijd met ruim $30 \%$ gedald. Onder het afgevloeide personeel van de bureaus bevinden $z i c h$ $B .4$ gekwalificeerde architekten, het antal direktieleden-architekten vermindert met $5 \%$, de niet-architekt direktieleden met $23 \%$.

Deze cijfers geven an dat op dat tijdstip de bureaustrukturen bezig zijn te veranderen. In de hoogtijdagen zijn veel grotere bureaus voorzien van ontwerpsekties bemand met gekwalificeerde architekten en specialisten op andere gebieden dan de ontwerpsektor. De ontwerpaktiviteiten schuiven weer naar boven nat zich verjongende direkties, de ouderen treden uit. De specialisten zijn een te zware kostenpost en kunnen niet meer worden gefinancierd uit de teruglopende winsten, moeten dus afvloeien. Deze kennis kan ook immers ad hoc incidenteel worden ingehuurd.

Tevergeefs vraagt de BNA om regeringsmatregelen om de bouwnijverheid van de uitzichtloosheid te verlossen. Zij beveelt aan:

- afschaffing of verlaging van de BTW onder verwijzing nat de situatie in België.

Deze matregel heeft aldaar op langere termijn overigens toch weinig sukses gehad (*92)

- meer restauratie-opdrachten, de kosten zouden wegvallen tegen het niet-uitgeven van werkloosheidsuitkeringen

- aanpassing van de Modelbouwverordening ter bestrijding van de beunhazerij. Titelwet.

over de vraag in hoevere sprake is van konjunkturele of strukturelle oorzaken van de inzinking van de bouwproduktie, komt steeds meer duidelijkheid. Dr. W. Roest (* 93 ) stelt "met vrij grote zekerheid" dat de ekonomische groel niet meer het niveau van de jacen wiftig en zestig zal halen, en dat er sinds 1970 sprake is van een struktureel dalende trend in de bouwproduktie, en dat deze trend is verdoezeld door een konjunkturele opleving in 1976-1979. 1970-1980 overziende konstateert hij dat in deze periode de bouwproduktie nauwelijks is toegenomen, tegenover een gemiddelde jaarlijkse groei van 5 à 5,5 in de twintig jaar daarvoor. Voorts dat:

- de woningbouw in aantallen is afgenomen

- de investeringen in de utiliteitsbouw het niveau van eind zestig niet meer hebben 


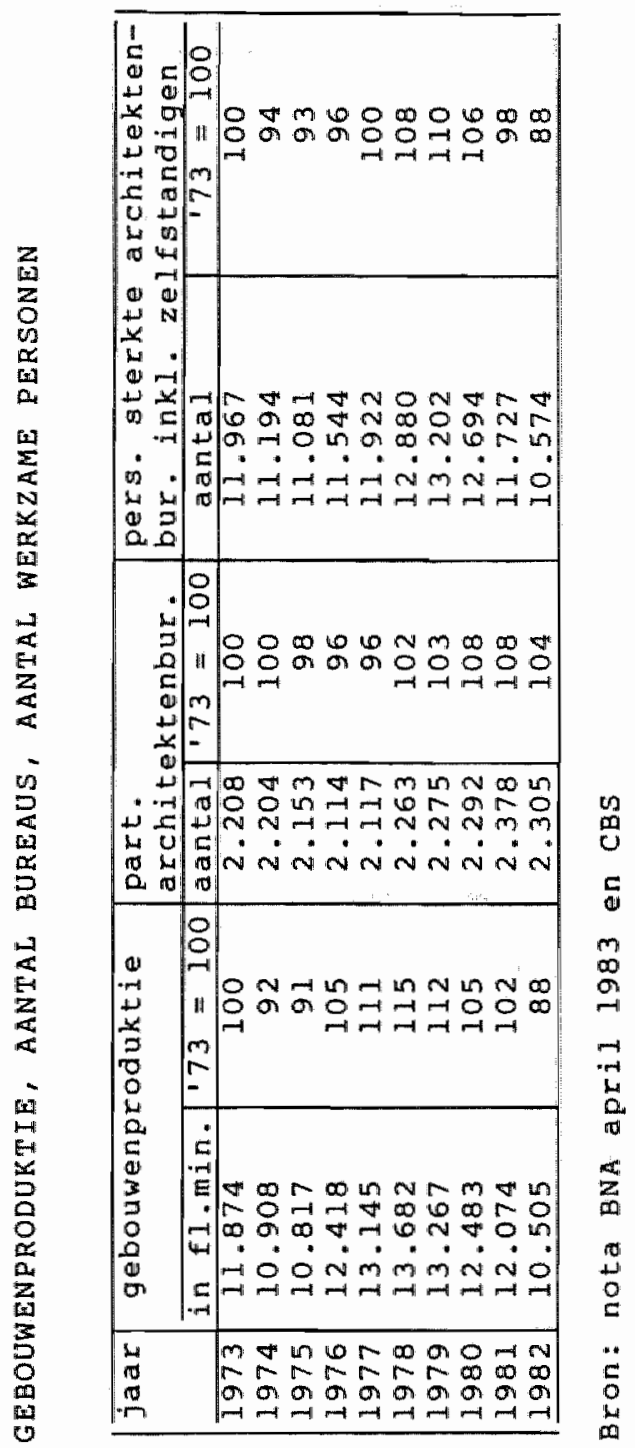




\begin{tabular}{|c|c|c|c|c|c|}
\hline \multirow[t]{2}{*}{ Jat } & \multicolumn{3}{|c|}{ aantal bureaus } & \multirow{2}{*}{\multicolumn{2}{|c|}{$\begin{array}{l}\text { werkzalm aantal. personen } \\
\text { (inkl. zelfstandigen) }\end{array}$}} \\
\hline & totan 1 & $\begin{array}{l}\text { Warvan } \\
1 \text {-mans }\end{array}$ & $\begin{array}{l}\text { wararun } \\
>50 \text { pers }\end{array}$ & & \\
\hline$\overline{1960}$ & 2.229 & 468 & $1 \%$ & 9.468 & $(100)$ \\
\hline 1970 & 2.483 & 418 & 18 & 14.56 .1 & $(154)$ \\
\hline 1979 & 2.275 & 368 & 18 & 13.202 & \\
\hline 1982 & 2.305 & $45 \%$ & 1\% & 10.574 & (112) \\
\hline
\end{tabular}

Bron: CBS

GEBOUWENPRODUKTIE, AANTAL BUREAUS, AANTAL WERKZAME PERSONEN

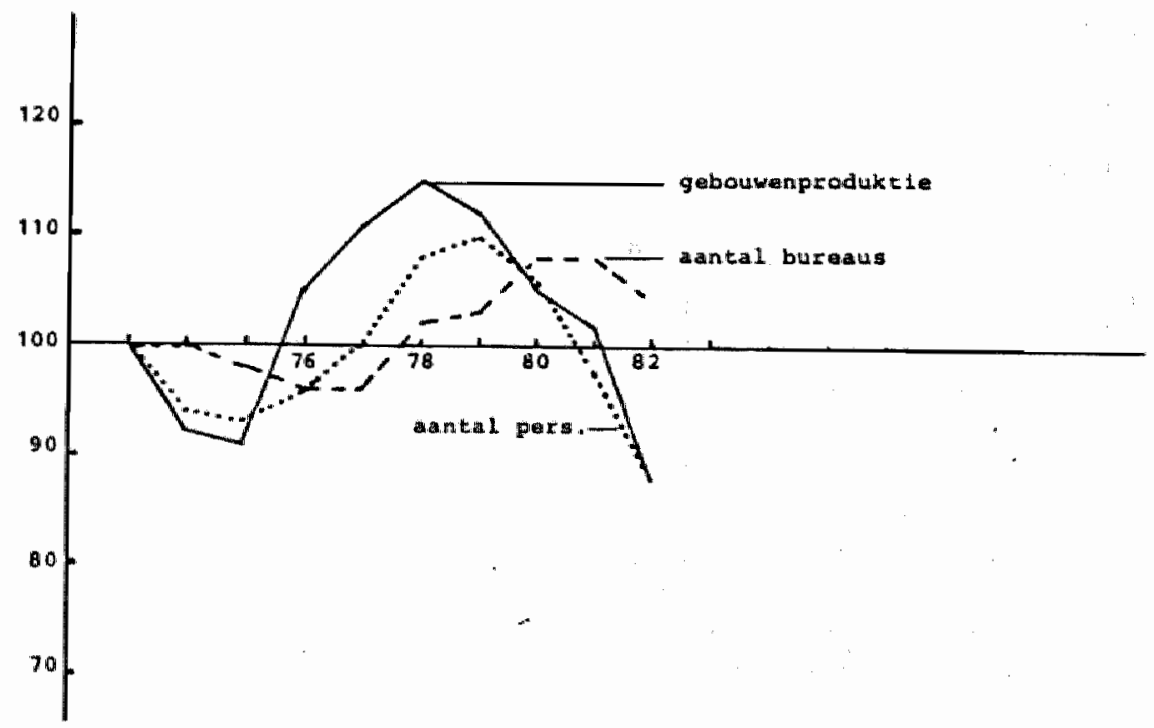

Bron: Nehem-rapport oriëntatie architektenbureaus 1983 
bereikt.

De in kategorieen vitgesplitste utiliteitsbouw lat het volgende zien.

Bedrijfsgebouwen:

- in de jaren zeventig hebben zich vele vernieuwingen voorgedaan binnen het bedrijfsleven. Door de verlaagde ekonomische groeit komt daraan rond 180 een abrupt einde.

onderwil jsgebouwen :

- lagere geboortecijfers doen de behoefte aan gebouwen afnemen.

Gezondheidszorg:

- het wegwerken van overkapaciteit is een vereiste, tegelijk met het doorvoeren van bezuinigingen.

overige gebouwen/overheidsgebouwen:

- ook hier budgettaire problemen en niveauverlaging van investeringen.

Dr. W. Roest voorziet de noadzaak van gigantische a anpasingen in de bouwnijverheid en vergelijkt de situatie in dat opzicht met de textiel en scheepgbouw. Hij wijst erop dat de verantwoordelijkheid daarvoor primair ligt bij de bedrijfstak zelf.

De BNA verwacht (* 94) dat de totale bouwproduktie tot 1986 met $18 \%$ zal dalen, een gelijke daling verwacht men in de bezeting van de architektenbureaus, warmee deze zullen zijn gehalveerd. Ook de vaste kern wordt daarmee aangetast, wat tot

kennisverlies moet leiden. Prof. dr. C.E. Engberts

konstateert (1981) een sterke overgang van

specialisten naar generalisten onder de architekten

en van groot naar klein (*95).

Er is zelfs een sterke groei in nieuwe éen-en tweemansbureaus, afgeleid $0 . a$. uit het BNAledenbestand. Bureaubeëindjgingen komen pas na 1981 voor.

Engberts signaleert over 1978-1981 de volgende tegengestelde ontwikkelingen:

\begin{tabular}{lll}
$\begin{array}{l}\text { ontwikkelingen van } \\
\text { aandeel }\end{array}$ & kleine bureaus & grote bureaus \\
\hline architekten & stijgt & \\
technici & dalt sterk & stijgt \\
adminstr. enz. & stijgt sterk & dadt
\end{tabular}

Bron: Bouw 1982 


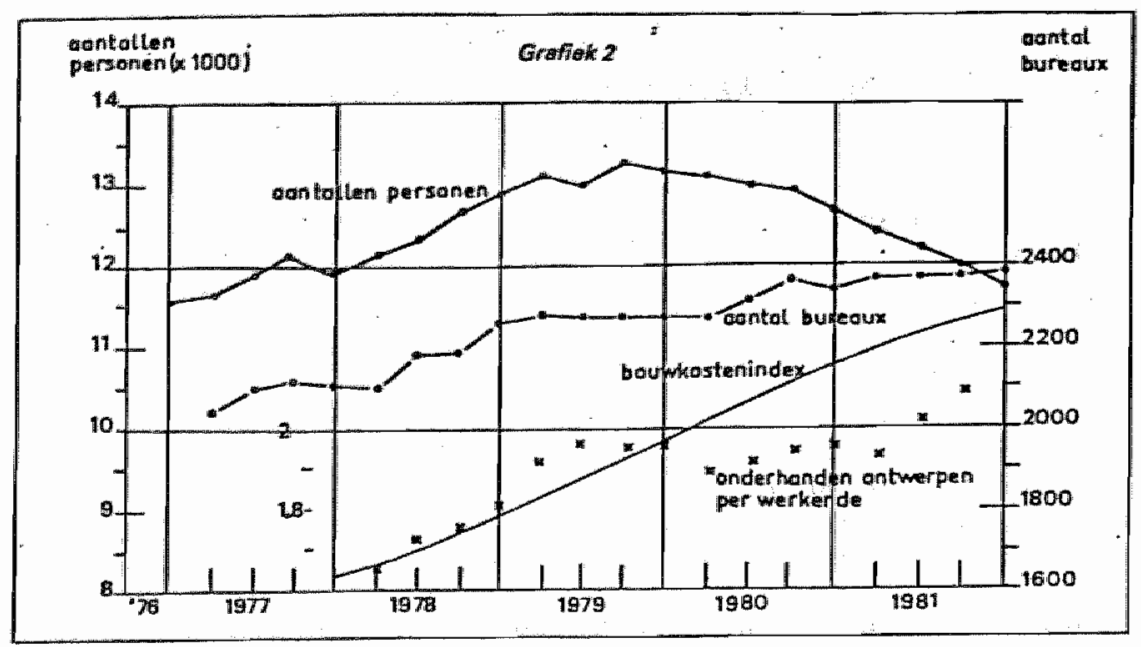

Bron: Bouw 1982 nr. 19

Tabel 3 Mutaties in de grootte van het architektenbureau in de loop van het jaar 1978 - 1981

\begin{tabular}{|c|c|c|c|c|c|c|c|c|}
\hline grootte & groei & of $\mathrm{kr}$ & & & op & ring & of $a f v$ & ing \\
\hline & 1978 & 1979 & 1980 & 1981 & 1978 & 1979 & 1980 & 1981 \\
\hline 1 & -12 & +11 & +68 & +112 & +61 & -21 & +39 & +30 \\
\hline$\overline{2}$ & 0 & -23 & +24 & +9 & +38 & +9 & +7 & +11 \\
\hline$\frac{3}{3}$ & -4 & +16 & -15 & -40 & +17 & +9 & +18 & -2 \\
\hline 4 & -2 & -1 & -15 & -13 & +9 & +7 & +3 & \\
\hline $5-9$ & +6 & -15 & -38 & $=49$ & +16 & +7 & +6 & -3 \\
\hline $10+$ & +12 & +12 & -24 & -19 & & & & \\
\hline
\end{tabular}

Bron: Bouw $1982 \mathrm{nr} .19$ 
De konklusie van Engberts is dat men bij de opleiding van bouwkundig ontwerpers bedacht moet zijn op de zwakke positie van de sterk gespecialiseerden op de arbeidsmarkt.

Een greep uit de konklusies van de studiedag Bouw/ Bouwcentrum/BNA op 26 november 1982 :

- architekten $z i j n$ superindividueel

- de architekt dreigt onevenredig $z$ war getroffen te worden

- de "totale" architekt heeft de beste papieren voor de toekomst

- de architekt moet $z i j n$ vertrouwensrol blijven spelen

- moet meer in politiek penetreren

- moet ondernemer zijn

- moet solidair zijn met gebruikers

- moet meehelpen aan een doorbraak van een archaische produktiewijze

- de architekt van vandaag lijkt op een held die wuivend ten onder gaat.

Soms lijken oplossingen voor de problematiek eenvoudig. Drs. R.J. de Wit, in zijn funktie van Commissaris van de Koningin in Noord-Holland, ziet het beroep van architekt heel pragmatisch als een gewoon ambachtelijk en bekwaam architektuurbeoefenen zonder veel gefilosofeer over de achtergronden. $(* 96)$.

Eind 1983 wijden Alexander Tzonis en Liane Le Faivre in Bouw (* 97) een hele serie artikelen aan de toekomst van de architekt. Een geruststellende konstatering luidt dat architekten alles hebben overleefd wat hen in de loop der tijden is aangedaan. Aan de andere kant geeft dat weinig soelaas voor hun positie. Voor het kastenvraagstuk van het bureau en de diskontinuiteit in de opdrachten, de flexibiliteit in de bezetting in relatie tot de sociale voorzieningen, worden geen oplossingen of indikaties gegeven.

Uit een interview-serie met architekten over de toekomst noteren zij in deze aflevering van "Bouw" de volgende uitspraken:

- de hoofdtaak van de architekt bestaat uit het struktureren van het afwegingsproces tussen ondermeer doelmatigheid, bellevingswatede, ekonomische en technische halbarcheid. In de adviserende rol komt het accent te liggen op het voor alle partijen toegankelijk maken van het afwegingsproces en in de uitvoerende rol op kwaliteits-, kosten- en procesbeheersing. Hiermee wordt het beroepsbeeld pluriformer en wordt een bredere deskundigheid gevergd. 
- Voor de kwallteit van de gebouwde omgeving, alsmede terwille van de bewonersinvloed op het bowwen, is het gewenst dat een groot aantal architektenbureaus zelfatandig blijt voortbestaan, onafhankelijk van overheid en bouwbdrijf. De kondities hiervoor $z i j n$ thans niet aanwig en moeten geschapen worden. (Mulder)

- Het goed geëquipeerde architektenbureau met voldoende mandaat van de opdrachtgever is de beste organisatie voor de voorbereiding en begeleiding van bouwprojekten.

- Opdrachtgevers zijn zich hoe langer hoe minder bewust van de kulturele betekenis van de behoefte die zij te vervullen hebben (Evers).

- Het is niet zozeer de architekt die iets bijzonders bedenkt, het is vaak de kombinatie architekt/opdrachtgever (Greiner).

- Een architekt is een mens. Een mens die dan nog kreatief is, laat $z i c h$ nooit voor één gatje vangen. Als je de architektuur degradeert tot een technisch probleem dan krijg je de situatie dat je je door andere technici het kaas van je brood laat eten. Wij zijn als architekten in gebreke gebleven om ons specialisme duidelijk te maken

(Hartsuyker).

- Architektenbureaus zullen het wat betreft de beheersing van het bouwproces in alle facetten moeten kunnen opnemen tegen elke organisatie gespecialiseerd of niet (Hoogstad).

- De traditionele architekt heeft zijn proceskennis laten overnemen door derden; de architekt dient $z i c h$ sterker op de proceskennis toe te leggen (Cohen).

- In het denken van de architekt zal het denken vanuit het ontwikkelingsproces een grote plaats moeten gaan innemen. De architekt zal dartoe moeten laten blijken dat hij kostenbewust is, industrieel kan denken, inventiviteit part aan kooperatie, en dat hij een toekomstvisie heeft.

- De architekten moeten proberen de gebouwde omgeving te verbeteren: door kreativiteit, samenwerking en produktontwikkeling. Overigens 
zonder daarbij hun zelfstandigheid te verliezen (Loerakker).

- Ik heb liever kleinere bureautjes met gedreven mensen, dan grote bureaus. Die vind ik de dood voor de architektuur. Die kleine bureaus zullen het wel moeilijik hebben, nu alles zo gekompliceerd wordt (Verhoeven).

- Ik vind wel dat wij kennis moeten nemen van al die (technische en organisatorische) zaken, als architekt, mar we kunnen ons laten bijstaan door andere vakmensen, mar als het om ruimtelijk antwoord geven gat, dan staan we op onszelf (Hurkmans).

- De taak van de architekt/vormgever lák zich niet wegleggen. Die taak heeft een veel

permanenter karakter en verandert zeer langzaam in de tijd en is afhankelijk van het soort organisatie en de omvang van de samenleving. De taak van o.a. architekten is te vechten voor handhaving van een duidelijk cultuurbeleid binnen de engere financiele mogelijkheden (Van Ardenne).

- Naar mijn mening moeten architekten een veel duidelijker garantie af durven en kunnen geven voor de kwaliteit van hun werk, zowel voor ontwerpkwaliteit als voor wat betreft technische en organisatorische aspekten (Manche).

Een dergelijk uitspraken-reeks is even divers als degenen die $z i c h$ ertae hebben laten verleiden. Er blijkt uit, dat, hoewel zij gedaan zijn in dezelfde kontext en op hetzelfde ogenblik, er geen grootst gemene deler valt te bepalen die als leidraad zou kunnen dienen voor een te ontwikkelen beleidslijn. Voor wie zou die overigens moeten dienen? Voor de BNA? Die bestat uit leden die even gedifferentieerd zijn als de gereleveerde uitspraken. Voor de opleidingsinstituten? Die zijn te druk in de weer met overleven in de tweefasenstruktuur en de

herstrukturering van het wetenschappelijk (Tu' - en hoger beroepsonderwijs (Akademies van Bouwkunst).

Nog enige andere visies op het matschappelijk funktioneren van architekten:

- de kollektieve reputatiebehartiging van de architekten heeft zeer veel te wensen overgelaten. De woningbouwbedrijven zetten er een groot vraagteken achter of de gemiddelde architekt zowel de deskundigheid als de 
mentaliteit bezit an wruchtbar als adviseur in het produktontwikkelingsproces te participeren (Van de seyp).

- Ik denk wel eens dat architekten, die gesuggereerde deskundigheden niet kunnen warmaken, meer afbreuk doen an het imago van ons beroep, dan architekten die een te laag tarlef berekenen (Mertens) (*98).

- We kunnen stellen, dat na de wereldoorlog 2 ons vak zich ontwikkeld heeft van een ambacht gebaseerd op traditie en praktijkgetoetste wakbekwamheid, tot een komplexe technologie, die zeer pluriform 13 , over te weinig langdurige ervaring beschikt en een beroep doet op het oorspronkelijk denken. Deze ontwikkeling is bijna exponentieel. We moeten echter helaas vaststellen, dat de architektenwereld deze ontwikkeling niet heeft bijgebeend (Gerritse) (*99).

In 1983 ontstat binnen de BNA een groep architektenbureaus die zich duidelijker wil profileren als type. De drang hiertoe spruit voort uit de noodzaak tot een andere marktbenadering om te kunnen overleven. Deze Vereniging Architekten Alliantie begint met een oplnie-onderzoek door het bureau Knapper en Mc Alley om de plaats van de architekt-van-nu te analyseren (* 100). De benadering van de opdrachtgevers levert voor de architekten onthutsende resultaten op. Dit leidt tot een studiedag op 20-03-85 warblj de volgende stellingen worden gehanteerd:

Stelling 1 :

- "de door de architekt aan hemzelf historisch toebedeelde "totaalfunktie" in het bouwproces is door de feiten achterhald"

Ste 11 ing 2 :

- "iedere poging, hetaij door individuele architekten danwel door samenwerkingsverbanden tussen architekten, om de klok volledig terug te draalen, is gezien de geloofwardigheidskloof enerzijds en de aanwezige alternatieven op de markt anderzijds, gedoemd tot mislukken"

Stelling 3 :

- "de architekt dient er naar te streven zijn verlocen positie deels terug te winnen, of in ieder geval verdere afkalving tegen te gaan, door beter tegemoet te komen aan de eisen van de markt inzake:

a) specifieke kennis op terreinen als $0 . \mathrm{m}$. bouwtechniek, kostenbeheersing, organisatie en 
logistiek:

b) een veranderde mentaliteit en opsteling: kreativiteit ten dienste van...."

Stelling 4 :

- "de architekt heeft zich altijd sterk opgesteld als individu, het bureau als een samenwerking van individuen, en dit wordt door de markt onderschreven. De architekten hebben nagelaten in te haken op de veranderingen in hun omgeving en hebben bilnnen hun bureaus niet de beschikking over juist die disciplines die door de markt in toenemende mate vereist worden. De multidisciplinaire mogelijkheden die een bureau-organisatie zou moeten kumnen bieden zijn er niet gekomen"

Steling 5 :

- "de architekt kan als architekt weer "meester" worden op die terreinen die hem door de markt als specifieke kundigheden worden toebedeeld. Hijkan noojt meer als "architekt" de "bouwmeester" worden die alle disciplines van het gehele, vandaag de dag uitermate komplexe en technologische tracé beheerst"

Stelling 6 :

- "wel kan de architekt zijn funktioneren in het bouwproces een aanzienlijke meerwarde geven door enerzijds een verandering in mentalitejt en anderzijds een koppeling van de vereiste specialismen en disciplines; hij wordt een volwardige gesprekspartner in het bouwproces als hij de beschikking heeft over deze kennis: dit niet zozeer als individuele architekt, maar als bureau of organisatie"

Stelling 7 :

- "aan het boveneinde van de markt is men hetzij teleurgesteld in het feit dat de architektenaanbieders de ontwikkelingen a an de vagajja niet hebben bijgehouden, ofwel men heeft inmiddels andere oplossingen gevonden met voorbijzien a an de architekt"

Het symposium leidt niet tot konkrete a anbevelingen.

De BNA start een public relations campagne o. a. door middel van advertenties. Een public-relationsbureau onderzoekt het effekt bij verscheidene kategorieën opdrachtgevers, daarbij werden dezelfde ervaringen opgedaan als bij Knapper en McAlley. 
Een kenschets van de kernproblematiek geeft

Dr. ir. Kroon:

"de architekt, zelf beroepshalve producent van ideeén, 1 s trouwens de enige funktionaris in het bouwproces die deze hulp, het ontwikkelen van talloze min of meer losse ideeën die opdrachtgevers gedurende het gehele proces naar voren brengen, met kennis van zaken kan verlenen. Het is opmerkelijk dat deze kenmerkende taak van de architekt beruat op de kreatieve houding van mensen tegenover architektuur, welke houding tegelijkertijd fnuikend is gebleken voor zijn beroepsbeeld" (* 101).

De zo bitter noodzakelijke maatschappelijke erkenning van de architekt blijft afhankelijk van politieke faktoren. Deze bepalen immers het wel en wee van het wetsontwerp dat strekt tot bescherming, nu van de titel in plaats van het beroep. Opnieuw wordt het initiatief op het allerlaatste moment getroffen door "deregulerings" matregelen van het kabinet Lubbers $I$. Het wetsontwerp was alle fasen van demokratische besluitvorming gepasseerd en kon rekenen op een meerderheid in de Tweede kamer. Het komt terecht bij de kommissie Geelhoed, die toetsend tot de konklusie komt:

- een eventuele bescherming van de (bouwkundige) architektentitel kan wachten op een $\mathbb{E E G -}$ richtijn voor diploma-erkenning

- grote en belangrijke projekten worden nu al steeds opgedragen aan gekwalificeerde architekten

- er zijn al heel wat regels en bevoegdheden tot bescherming van de kwaliteit van het werk: een erkende architektentitel hoeft daar niet. nog eens bij

- konkurrentie tussen erkende en niet-erkende beroepsbeoefenaars is onvoldoende grond voor overheidainterventie

Het eigen beeld van de architekt in relatie tot zijn partners in het bouwproces ligt anders dan de feiten a angeven, zoalg blijkt uit het onderzoek

"Bouwcontouren" (* 102) van 1984. Het onderstreept de konklusie van Knapper en MCAlley. 
De balans opmakend ultimo 1984 kunnen de volgende konklusies worden getrokken:

- de strukturele teruggang in de bouw veroorzaakt een vermindering van de vraag nar architektendiensten, die nog versterkt worden door de konjunktuurneergang

- het vertrouwen van de opdrachtgevers in de architekt als spil van het bouwproces behoort tot het verleden. Als participant in het bouwproces wordt hij tot op zekere hoogte geaccepteerd. De organisaties van professionele opdrachtgevers hebben hun eisen zodanig geformuleerd dat de rol van de architekt nog slechts als vormgever wordt ingeschat. De synthese van vorm en techniek blijft valk nog wel een deel van zijn taakgebied, binnen strikte grenzen, max de kruisbestuiving met sociaal-matschappelijke faktoren vindt niet meer plats

- de funktionele eisen van techniek en kosten bepalen de architektuur, de marges in dit spanningsveld zijn nauwelijks meer aanwezig. Daarmee wordt de vormgevende funktie van de architekt in feite tot een minimum gereduceerd

- de discontinuiteit in opdrachten en het statische kostenbeeld van zijn praktijk bedreigen de architekt als ondernemer.

- opdrachtgevers vinden dat architekten tekort schieten op het gebied van materialenkennis. kostenbesef, en het eerbiedigen van tijdschema "s.

IV. 2,4

het verschijnsel deelopdrachten

Reeds vóór 1940 was er sprake van deelopdrachten wanneer men de totalopdracht van de architekt beschouwt als één van (schets) ontwerp tot en met eilndoplevering overeenkomstig art. 4 AR (in de SR"87 inklusief toezicht art. 57 1 id 4 SR'87). Dat bleek vooral in de diskussies rond de ontwerparchitektenwet 1949. Daarbij was een beroepsbescherming voorzien tot de aanbesteding. Daarna was er sprake van een "vrije" situatie, zulks met het oog op het uitvoerend bouwbedrijf dat, als eigenbower, de direktievoerende architekt niet van node had. Het standpunt dat de hoofdrol door de architekt slechts tot de aanbesteding hoefde te worden vervuld, kende ook in architektenkringen toen nogal wat medestanders. Dat de architektenopdracht soms in tweën werd gesplitst was dus niets opzienbarends.

Dat was wel de uitslag van de (beperkte) BMA-enquête 1983 naar het verschijnsel van de onvolledige opdracht. Daarbij kwam vast te staan dat bij de 


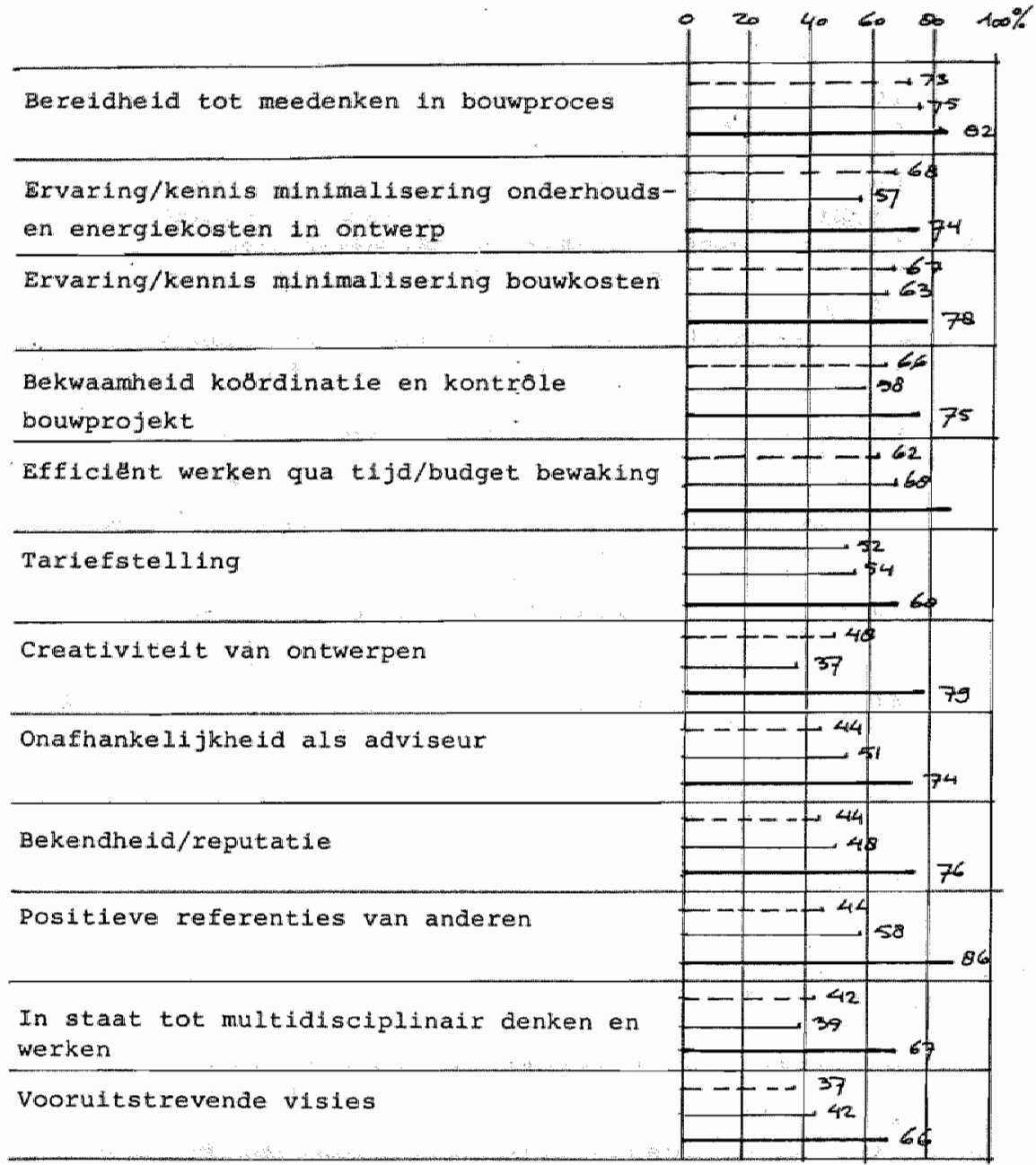

- - - opdrachtgever

aannemer

archilekt

De visie op ijn funktomeren wat de aronltekt er zifif en wat anderen iran denken.

Uit: Bouwwereld nx. 23 a.d. 16-11-1984 
onderzochte buceaus (100) slechts 198 van het aantal opdrachten volledig was, bij 8 geheel onvolledig.

Deze onvolledige opdrachten kwamen 0.a. van het Rijk (128), gemeenten (35\%), woningbouwverenigingen (438), bouwondernemingen (508), projektontwikkelaars (478), stichtingen, gesubsidieerd door overheid ( $33 \%$ ) en partikulieren (47\%). In veel mindere mate van grote bedrijuen (13\%).

De niet opgedragen onderdelen werden veelal door de opdrachtgever zelf gedaan, te weten:

Rijk $40 \%$

Gemeente 868

Woningbouwvereniging $79 \%$

Bouwondernemingen $91 \%$

Projektontwikkelaars $80 \%$

Stichtingen, gesubsidieerd door overheid $67 \%$

Partikulieren 698

Grate bedrijuen 778 .

Van het totaal antal opdrachten werd in $x$ geen opdracht verleend voor de in matrix op blz. 172 vermelde fasen.

Gevraagd naar de redenen van de onvolledigheid werden het meeste genoemd:

- bezuinigingen (vermeende kostenbesparing);

- tegengaan leegloop opdrachtgevers (oparachtgever heeft mankracht + kennis):

voorts:

- niet erkennen totale opdracht (architekt is silechts tekenaar of is slechts nodig om een bouwvergunning te krijgen):

- konkurrentie van bouwbedrijven, projektontwikkelaars en bouwkostenbureaus;

- (vermeend) gebrek aan kennis bij de architekt voor wat betreft de financielle kant:

- standaardisatie:

- woningbouwverenigingen en gemeenten zijn niet BTWplichtig

Tot zover de BNA-enquête.

voor de toekomstverwachtingen van datzelfde rapport zij verwezen naar de tabel op blz. 174 


\section{herstel en vabouw \\ 1 Nieuwbouw, herbouw. uit thow \\ 1.1 moningwet-premie= carporatie $A$ en premi hutroning \\ 1.2 premie -woningen \\ 1.3 premie B-woningan \\ 1.4 womingen veije sektor \\ 1.5 gebouwen gezond- thesaszorg \\ 1.6 bedrijtegebouwen (w o. agrartische gebounen) \\ 1.7 onderwi jagebouwen \\ 1.a maere bijzondere $g$ bouwen \\ 1.9 overheidsgebouwen}

\begin{tabular}{|c|c|c|c|c|c|c|c|c|c|c|}
\hline 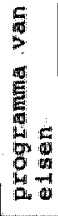 & 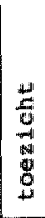 & 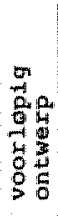 & 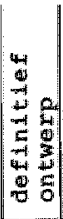 & 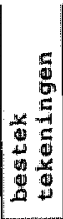 & $\mid \begin{array}{l}x \\
0 \\
1 \\
0 \\
0 \\
0 \\
0\end{array}$ & 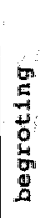 & 管 & 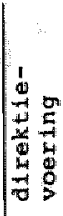 & 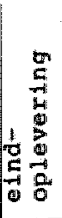 & 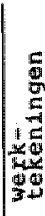 \\
\hline 73 & 56 & 4 & 4 & 8 & 18 & 27 & 31 & 135 & 35 & 31 \\
\hline 87 & 76 & 2 & 1 & 3 & I. 4 & 44 & 43 & 46 & 46 & 10 \\
\hline 76 & 87 & $I$ & 4 & 6 & 41 & 84 & 82 & 75 & 73 & 21 \\
\hline 85 & 87 & $=$ & 5 & 5 & 42 & 87 & 72 & 54 & 57 & 20 \\
\hline 70 & 73 & - & 2 & 8 & 30 & 58 & 57 & 56 & 58 & 36 \\
\hline 61 & 39 & 1 & 1 & 5 & 11 & 16 & 19 & 19 & 18 & 10 \\
\hline 81 & 60 & 5 & 6 & 9 & 34 & 47 & 50 & 47 & 47 & 31 \\
\hline 71 & 32 & - & 12 & 17 & 17 & 24 & 21 & 19 & 20 & 21 \\
\hline 69 & 49 & 1 & 7 & 12 & 119 & 34 & 33 & 34 & 33 & 26 \\
\hline 81 & 5.2 & 6 & 6 & 13 & 13 & 15 & 19 & 24 & 23 & 22 \\
\hline
\end{tabular}

Bron: BNA-enquâte d9a3 
De splitsing van de opdracht verloopt langs bepaalde lijnen, veelal zullen die aspekten afvallen warin men de architekt minder bedreven acht. Het rapport van Knapper en McAlley "de architekt in de jaren 80 " geeft dararvan het valgende beeld:

"Waar vindt men de architekt nu echt goed in

De architekt is de vormgever, de ontwerper, de leverancier van koncepten, van een visie, van i deeën.

Voor een kleine minderheid kan hij naast deze aspekten ook nog tot zijn sterke punten rekenen: organisatorische kwaliteiten (koördinatie van het bouwproces en dergelijkel en een soort liaison-funktie tussen vorm, funktie en uitvoering.

Waarin schiet de architekt duidelijk te kort

op dit punt heeft men aanmerkelijk meer te vertelien dan over de positieve aspekten en ook hier kan een onderscheid worden gemaakt tussen feitelijke kennis en kundigheden enerzijds en individuele attitude/opstelling anderzijds.

Feitelijke aspekten

- kosten, kosten, kosten:

- vaak ontbreekt deskundigheid op dit terrein

- ook kostenbewustzijn ontbreekt, de mentaliteit is niet juist

- organisatietalent:

- aan het huidige eisenpakket inzake managementkwaliteiten wordt niet voldaan

- bouwtechnische deskundigheid:

- onvoldoende kennis (bouw, onderhoud, e.v.a.)

Attitude/opstelling

- de architekt is te individualistisch, funktioneert niet in het kollektief dat heden ten dage het bouwproces begelleidt

- de architekt denkt te weinig funktioneel

- de architekt denkt te weinig in termen van kosten

- de architekt stelt zich te weinig zakelijk op

Wat zijn de oorzaken en wat is er aan te doen

In essentie komt het er volgens de ondervraagden op neer, dat de architekt passief en genakzuchtig de veranderde omgeving over $z i c h$ heen heeft laten komen, en volstrekt te kort geschoten is wat betreft het inspringen op deze gewijzigde situatie.

Natuurlijk zijn er ook wel meer exogene faktoren 


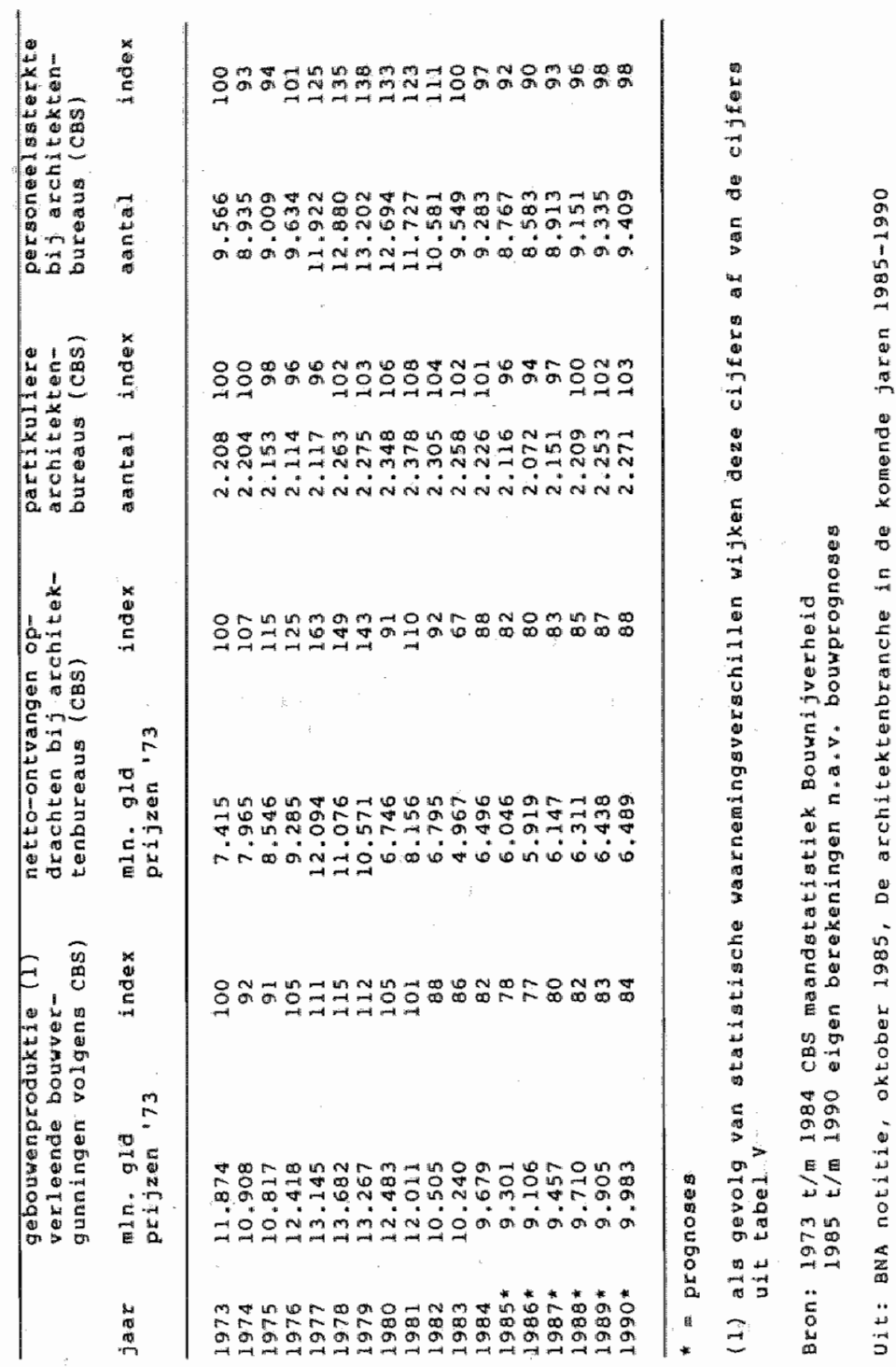


vit: BN notitie, oktober 1985, De architektenbranche in de komende jaren 1985-1990

Gebouwenproduktie, netto-ontvangen opdrachten, aanta i en persone 1 ssterkte bij architektenbureaus.

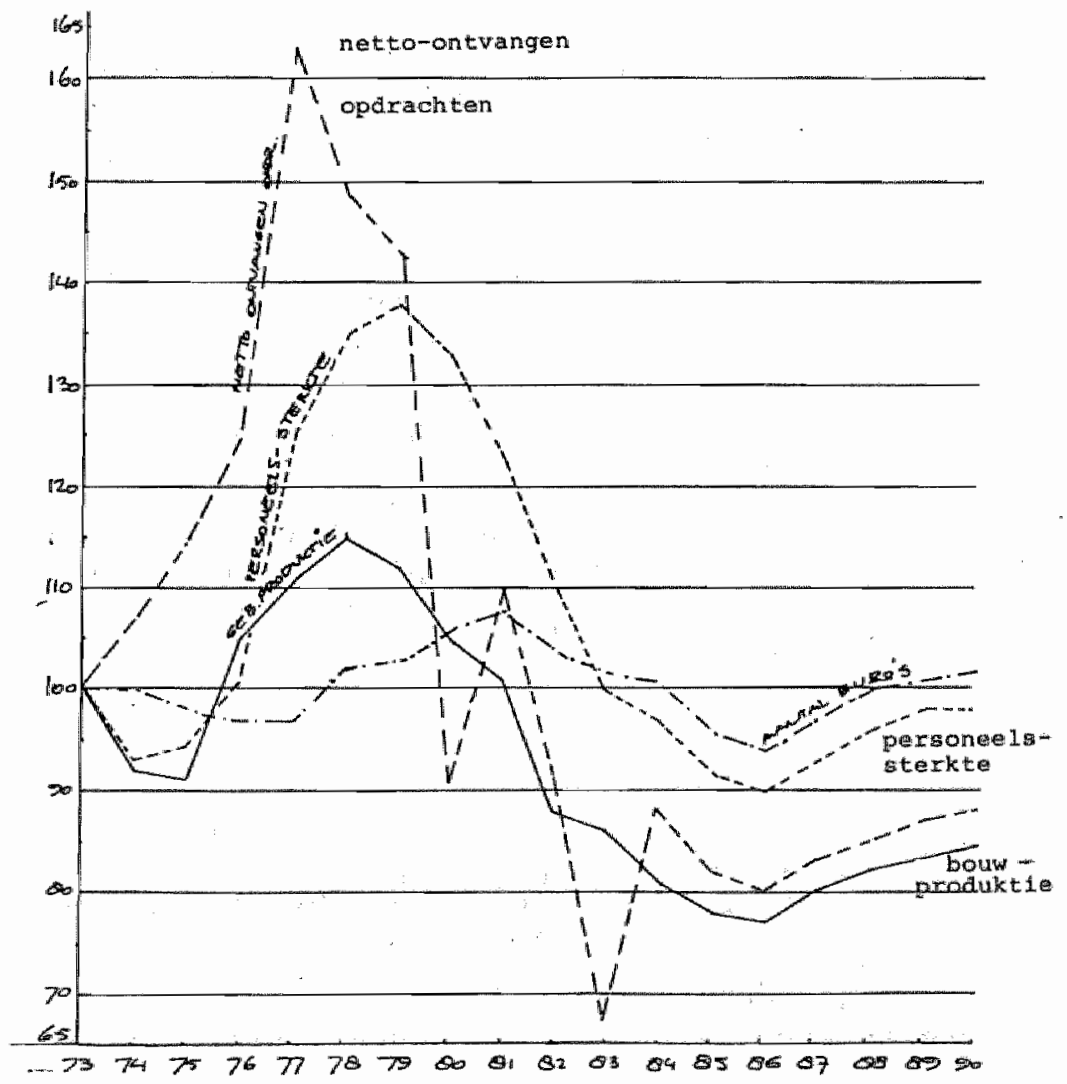


aan te wijzen, waronder de economische situatie, mar dit wordt bepald niet als de doninerende reden voor dit falen gezien. Natuurlijk treft ook de opdrachtgevers zekere blam, zij hebben deze houding wan architekten zo niet gestimuleerd dan toch wel getolereerd. Maar het wereldje van de architekt zelf is verantwoordelijk voor de gebrekkige kennis, de tekort schietende opleidingen, het niet inspringen op veranderingen en technische ontwikkelingen.

Het is dan ook niet zozeer de vraag wat kunnen ze eraan doen, maar weeleer wat moeten ze eraan doen.

Op deze vraagstelling komt de toch overwegend welwillende opstelling van de respondenten duidelijk nat woren:

- werk wat meer samen, bundel specialismen of makk ze je elgen, versterk het vak van binnen uit

- doe snel en op niveau iets an de opleidingen Moot:

dit slat bepald niet alleen op de basisopleidingen, integendeel, men refereert hier bovendien specifiek aan bijscholing van hen die de boot aan het missen zijn

- ga eens drastisch timmeren aan de mentaliteit:

- laten de architekten zich eens wat zakelijker opstellen

- probeer die "heilige" kreativiteit eens te kombineren met kostenbewustzijn, funktioneel denken, het vinden van oplossingen binnen steeds moeilijker wordende omstandigheden voor alle betrokkenen dus "ook voor de principaal"

IV .2 .5

na 1985

In de verwarde situatie van ultimo 1984 is het moeilijk om en toekomstvisie te ontwikkelen. sterk zal de situtie worden bepald door de vooruitzichten in de bouwnijuerheid en die op hat beurt weer van de agehele ekonomische situatie.

Men gewagt in dat opzicht van een voorzichtig herstel, dat voornamelijik wordt veroorzaakt door een verbeterde exportaituatie. De bouwnijverheid raakt dat thans nog niet direkt. Dat zal pas het geval zijn wanneer het bedrijfsleven de fase van herinvestering in arbeidsbesparende produktiemiddelen voorbij is en uitbreiding en aanpassing van gebouwen vereist wordt. De bouwnijverheid zal voorlopig zeer worden geremd door de budgettaire matregelen van bedrijfsleven en overheid. 


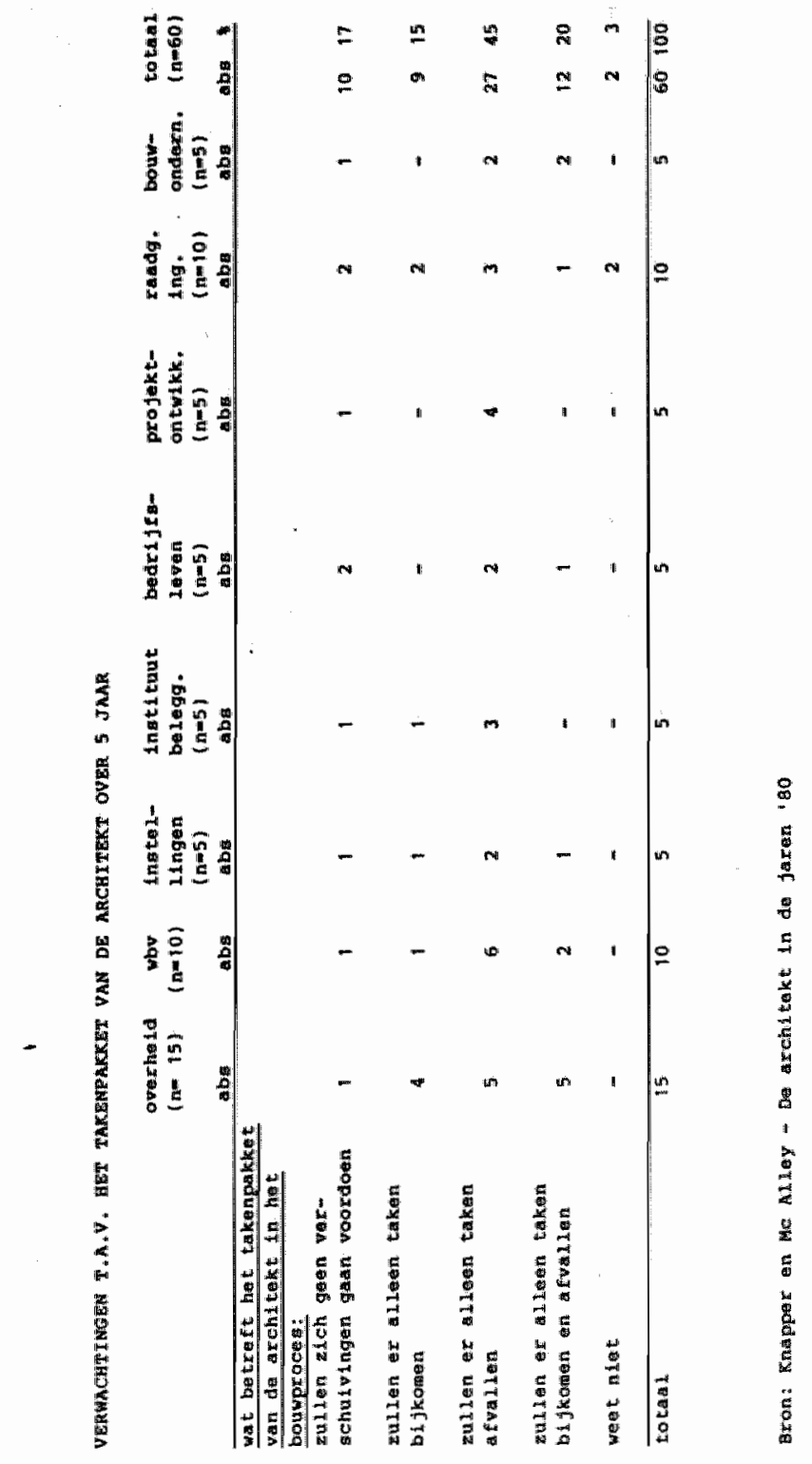


Woor de architekten betekent dat nog grotere perioden tussen het scharse werk, van wachten. Het daaruit wookt loeiende kostenprobleem zal dwingen tot koncentratie enerzijos van architektenbureaus, terwijl op de bureaus zelf de werkamheden naar de top zullen verschuiven. Relatief dus meer hoger gekwalificeerden in het personeelsbestand. Daarnaast zal het eenmansbureau een stevige konkurrent voor het kleine werk blijven.

De architekt zal meer vakkundig moeten zijn op meer facetten van het bouwen. Op dat punt bestat een achterstand.

Wanneer de architekten een worm kunnen vinden van gekoncentreerde "dienstverlening aan de opdrachtgever door samen te werken in ad hoc verbanden met de a anleunende disciplines, de afgescheiden broeders van weleer, zal een kontraktuele duidelijkheid ontstaan jegens de oparachtgever, die het herstel van de matschappelijke acceptatie zeer gunstig zal beînvloeden; de architekt als vertegenwoordiger van alle ontwerpende disciplines.

Primair zal een bevordering moeten platsvinden van begrip voor het kulturele aspekt van bouwkunst bij het brede publiek en een heroriëntatie op de fysische, ekonomische en funktionele aspekten van het bouwen bij de architekten.

Voor het eerste is de totstandkoming van een Architekturinstituut van het grootste belang. Van daaruit kan een edukatieve bijdrage worden gelevera aan de vorming van jongere generaties en wardering en begrip voor de kulturele warde van de gebouwde omgeving.

Voor het overige is een heroriëntatie nodig op de opleidingen van architekten teneinde het specialigtische architektenmodel om te buigen naar het generalistisch beeld war de huidige tijd om vraagt.

Veel zal afhangen van de mate van flexibiliteit warmee de architekt zich opstelt in de bouwwereld van de toekomst. Deze flexibiliteit mag er echter niet toe leiden dat de architekt koncessies doet an de architektonische en technische kwaliteit van $z i j n$ arbeid. Hij zal bereid moeten zijn zijn specifieke tak in het wordingsproces van de gebouwde omgeving ook te verdedigen.

IV. 3

De opleiding tot architekt

Wanneer thans de matschappelijke positie van de 
architekt ter diskussie stat als gevolg van een vecondersteld falen in zijn deskundigheden; moet de oorzaak daarvan niet primair worden gezocht in de tekorten van de huidige opleidingen, mar in die van de jacen vijetig en zestig. Uitgaande van een gemiddelde studieduur van negen jaar (* 103), warbij zeker vier jaar beroepspraktijk moet worden opgeteld alvorens men van een zelfstandige architekt kan spreken, duurt het derhalve 13 jaar alvorens sprake is van een matschappelijke konfrontatie. Als dan ook in de zeventiger jaren de kritiek hoorbaar wordt, ligt de kiem daarvan na de jaren vijftig. De kritiek spitst $z i c h$ toe op de integratie van techniek en vorm in kombinatie met de bouwekonomische aspekten. Verwonderlijk is dat niet, in de genoemale tijdsperiode werden vakken als begrotingstechniek, en bouwekonomie in het geheel niet gedoceerd, laat staan in kombinatie met het ontwerp.

Het konstruktief onderwijs werd grotendeels bepaald door de ambachtelijke opvattingen van vóór-en vlak na de oorlog.

Moderne bouwmethodieken en ontwerpanalyse kwamen alleen aan de orde voor hen die "utiliteitsbouw" a is eindspecialisatie kozen.

Voor de beroepsbeoefenaars uit de tijd van hoogkonjunktuur (1960-1972) gelden deze beperkingen in nog sterkere mate. Het is hoogstonwarschijnlijk dat zij de technische ontwikkelingen konden bijhouden. De bouwekonomische aspekten speelden in die tijd geen doorslaggevende rol. Weelal was slechts van belang in hoeverre het bouwprojekt de status van de opdrachtgever weerspiegelde, althans in de utiliteitsbouw. Daarmee kwam voor de architekt ook een extra nadruk te liggen op de vormgeving.

$\mathrm{Na}$ de kentering in 1973 kwam hierin een verandering, ten nadele van de vormgever-sec.

Als reaktie op de welvartsbloei ontstat an het eind van de jaren zestig bij de studenten, althans aan de TUD, een matschappij-kritische attitude, die via demokratiseringsprocessen zijn weerslag vindt in het onderwijssysteem. Het begrip "architekt" komt daarmee in diskussie. Als begin daarvan kan worden aangemerkt de Forum-diskussie van 9 mei 1969 op de afdeIling Bouwkunde van de TuD (*104). Het demokratiseringsproces in de darop volgende jaren verschoof het accent van de studie sterk nat de sociaal-matschappelijke zijde, terwijl bovendien de vrijheid van de student in de amenstelling van zijn studiepakket de korrelatie tussen techniek, ekonomie, en vormgeving in de bouwopgave uit har evenwicht bracht.

De bouwekonomische kant van de bouwopgaaf is helemal 
het stiefkind van de opleiding. In een brief a n het Bestuur wan de afdeling Bouwkunde (10-11-1972)

bepleit Dijkstra de instelling van een leerstoel bouwkostenplanning. Dit om tegenwicht te wormen tegen de "deskundigen" die in veel gevallen door onvoldoende begrip voor het ontwerpproces een gevarlitke en procesverstorende invloed kunnen kijjgen, wat utteindelijk kan leiden tot irrationeel gebruik van het ekonomisch kriterium en tot een vecontrustende verschraling van de gebouwde ongeving" $(* 105)$.

Het is niet zo dat de bouwtechnische vakken niet worden gedoceerd, mar de synthese in de bouwopgave ontbreekt. In 1976 wordt nog gekonstateerd (* 106) dat de andacht van het onderwijs te zeer is gericht op vormgeving en op het overheidsbeleid inzake het bouwen, en te weinig op de matschappelijke problematiek die eraan ten grondslag ligt. Dit latste facet wordt overigens alweer sterk overbelicht. Het is niet zo dat de onevenwichtigheid tussen vormgeving en moderne bouwtechnologie onopgemerkt is gebleven. Prof. Gout stelt echter dat het bespreekbaar maken van deze problematiek niet mogelijk is gebleken als gevolg van de politieke struktuur van de afdeling ( $* 107)$.

Ook voor afgestudeerden blijkt al snel de harde praktijk; Benthem-Crouwel:

"de moderne bouwmarkt legt een hoge beperking op, in zo'n situatie zouden juist bouwkundigen nieuwe oplossingen moeten voorstellen. Maar het beeld is ontstaan dat de architekt een kunstenaar is met leuke ideeën. Hij moet echter meer ingenieur dan vormgever worden".

Een grote schok brengt de tweefasenstruktuur teweeg, watrbij bovendien de opleidingen worden

gekonfronteerd met werkloosheidsproblemen van hun abituriënten. voor het Wetenschappelijk onderwijs betekent deze onderwijsstruktuur een vierjarig curriculum dat leidt tot het ingenieursalploma en dus ook tot een gekwalificeerd architekt.

Inmiddels is in het beroepsveld het besef gerijpt dat er an de kwaliteit van de beroepsbeofenar moet worden gesleuteld en dat het begin darvan in de opleiding is gelegen.

Naast Delft leidt sinds 1972 ook Eindhoven op tot bowwkundig ingenleur/architekt. De opleiding aldaar was van origine meer gericht op bouwmethodiek en bowwechnologie en -systematiek. De Eindhovense opleiding is gua studentenaantal in vergelijking met Delft, zeer bescheiden. 
De opleiding a an de zes Akademies van Boukkunst is gebaseerd op het concurrency-principe hetgeen inhoudt dat de (avond) studerende daags werkt in de beroepspraktijk en daar de ervaring op doet op bouwtechnisch gebied. De ondergrond daarvoor wordt gevormd door de door de student gevolgde vooropleiding in de vorm van hoger technisch onderwijs. Het accent van de studie komt daarmee automatisch op het vormgevende aspekt van het vak te liggen.

De integratie van technische-, ekonomische en vormgevende aspekten in de bouwopgave van de Akademie-student is daarmee echter nog niet per definitie een feit: dat hangt af van de insteling van de betrokken Akademie c.q. docent.

De concurrency-formule wordt anno 1985 bedreigd door de dalende werkgelegenheid op de architektenbureaus, warbij veelal juist het middenkader wordt

uitgestoten. ( $* 108$ ). Juist daaronder bevinden $z i c h$ vele aspirant-architekten.

Rond 1980 komt de herstrukturering van het Hoger Beroepsonderwijs en het wetenschappelijk onderwijs in een kritieke fase. Het streven van de landsregering is er een van "Taakverdeling en concentratie" hetgeen o.a. inhoudt dat er grote clusters worden gevorma van opleidingen met eenzelfde gerichtheid. Dat geldt vooral voor het loger Beroepsonderwijs. De Akademies van Bouwkunst hebben voor dit type onderwijs gekozen. Aangezilen de genoemde clusters een minimaal antal van 600 studenten moeten hebben om zelfstandig te kunnen opereren, en géén der Akademies van Bouwkunst dit aantal halt, sluiten zij zich an bij de sektor Kunstonderwijs. In het totaal van de HBo-opleiding makt de opleiding tot architekt mar een zeer klein deel uit. Dat schept gevaar voor de kwaliteit en het voortbestaan van de opleiding.

In de twee fasen struktuur valt de Akademie-opleiding in de tweede fase van het HBO (eerste fase 1 i de HTS). De opleiding tot architekt (bouwkundig ingenieur) via het wetenschappelijk onderwijs valt echter in de eerste fase van dit anderwijstype. Een tweede fase is er niet.

Beide opleidingstrajekten leiden tot eenzelfde kwalifikatie (mogelijk toelating tot de BNA c.q. het Architektenregister). De wegen dartoe verschilien echter zozeer dat getwijfeld kan worden aan de vergelijkbaarheid van het eindprodukt, de afgestudeerde.

In de loop van 1984 richt de BNA een werkgroep op die belast wordt met het formuleren van de begintermen van de becoepsuitoefening met het oog op de gewijzigde beroepsomstandigheden enerzijds en de 
herstrukturecing wan het wetenschappelijk onderwijs anderzijds. Het in mart 1985 verschenen eindrapport wan de werkgroep (* 109) heeft de basis gevorma voor dilogen met de opleidingsinstituten over de inhoud van het studieprogramma.

Hoewel de BNA zich zeer veel moeite heeft getroost om het gesprek tusien de verschillende instituten op gang te brengen, 1 dat eind 1985 nog steeds niet gelukt.

De BNA konkretiseert $z$ ich daarom op de opleidingsinstituten zelf: met de Technische Universiteiten te Delft en Eindhoven worden diskussies gevoerd over de inhoud van de studieprogramma's.

Het als gevolg van de onderwijsherstrukturering opheffen van de Centrale Rad van de Akademies. warin zij allen verenigd zijn, berooft de BNA van. een gesprekspartner namens de Akademies. Hoe dat vacuum moet worden opgevuld is eind 1985 volstrekt onduidelijk. Enige katalyserende werking zal hopelijk uilgaan van de invoering van de wet op de Architektentitel.

In voorgaande hoofdstukken van dit proefschrift is meermalen a angeduid dat de kwaliteit van de opleiding in feite het matschappelijk niveau bepalt bij de latere beroepsuitoefening. Dat niveau is ook bepalend voor de rechtspositie van de architekt. In dat opzicht is een gerechtvaardigde vrees voor de toekomst gewettigd. 


\section{SAMENVATTING}

$1945-1985$

In deze periode heeft de matschappelijke positi wan de architekt een ingrijpende wijziging ondergaan. Aan het begin van de wederopbouw nog gekwalificeerd als het middelpunt van het bouwproces ontstaat al snel een spanningsveld met, vooral, het uitvoerend bouwbedrijf. Dat tracht te penetreren in het specifieke taakgebied van de architekt: het totstandbrengen van het uitvoeringsgerede ontwerp. Deze strijd koncentreert $\mathrm{zich}$ rond het wetsontwerp tot bescherming van het beroep van de architekt van 1949. Dile strijd blijft onbeslist, mar in feite wordt het een nederlaag.

De architekten hebben in hun schijnbat onantastbare positie geen oog voor de strukturele veranderingen die zich in hun taakgebied voltrekken. Er komen

"meeliggers" die haast ongemerkt delen van het architekten-takenpakket overnemen, omdat de architekten lacunes laten ontstan. Dat zulks gebeurt is een gevolg van het tekortschieten van de opleidingen.

Wanneer in het begin van de zeventiger jaren de ekonomische recessie inzet wordt, matschappelijk gezien, de balans opgemakt. Vanuit de Einanciele hoek wordt de architekt gewogen en, over het tataal van zijn historisch takenpakket, te licht bevonden. Er ontstaan deelopdrachten voor die onderdelen warin men de architekt nog bij uitstek geschikt acht.

Katalyserend werkt daarbij het modeverschijnsel dat grote opdrachtgevers uit organisatorische overwegingen delen van het architektenpakket naar zich toohalen.

Met de partiele opdracht doet bij de architekt ook de kommercie zijn intrede: bij gebrek an een adequate rechtsverhouding moet hij onderhandelen over de prijs van zijn diensten. Dat gat hem slecht af, en leidt tot verder kwaliteitsverlies en ut tholling van "binnenuit". Ekonomisch gezien gat het architektenbureau snel bergaf, met alle gevolgen van dien.

Rond 1985 stabiliseert zich de situatie. Er is nog slechts een handvol grootschalig georganiseerde architektenbureaus over. De middelgrote blijuen in aantal ongeveer gelijk, de kleine nemen sterk in aantal toe.

Dat zou erop kunnen wijzen dat de centrale positie van de architekt over het geheel genomen, definitief tot het verleden behoort. Geheel gemist worden kan 
hij nooit, er zal altijd behoefte blijven bestaan aan een scheppende en ordenende hand. Deze dienstverlenende taak zal echter moeten worden verleend vanuit een andere optiek dan voorheen.

Het zal voor het voortbestaan van het beroep van levensbelang zijn of de opleidingsinstituten hun taak op de juiste ijze inschatten en vervullen. Daartoe is het meer dan ooit noodzakelijk dat er ten a anzien van de studieprograma's nauw overleg blijt bestaan met het beroepsueld. 
IV. 5

NOTENLIJST

1. Prof. Dr. F. Hartog

2. Tweede Kamer der Staten-Generaal

3. Prof. Mr. B.M. Telderstichting

4. Prof. Dr. ing. A. Hendriks

5. M. Weisglas

6. Prof. Dr. ing. A. Hendriks

7 Prof. Dr. ing. A. Hendriks

8 Drs. G.E. Engberts

9. Bouw $1945 / 46$

10. W.H.M. Meeuwese

11. H. Wesselo

12. ir. J.J. van der Wal

13. ir. G. Friedhoff

14. J.P. Mieras

15. J.P. Mileras

16. J.P. Mieras

17. R. Furneaux Jordan
- "De Nederlandse Economie 19451970, Bouw 1970-17, blz, 695 e.v.

- verslag 45 e vergadering $2-2-1950$

- "Het woningbouwvragstuk in een beslissende fase, Den Haag 1959

- oratie UVA 08-11-1965

- Het Nederlandse bedrijfsleven in de jaren ' 60 - EC.Stat. Berichten 17-12-1969

- De veranderende bouwopgave Moussault Weesp, 1984, b1z. 79

- Een keerpunt in de produktie, Delft Universiteit Press oktober 1978

- De Bouwnijverheid in de jaren zeventig, Bouw 1973 nr.29, blz. 713

- "Architecten komen voor hun recht op", blz. 198

- Rolverdeling in de Volkshuisvesting plan $1983 \mathrm{nr}$. 2, b1z. 45

- "Architecten in nood" , Bouwkundig Weekblad 1945/46 nr. 35 blz. 311 e.v.

- "De aanbesteding van werken" Bouw mart 1947 , b1z. $89-92$

- Architect en Wederopbouw, Bouw 1947, blz. 288

- "De architect en zijn beroep" Bouwkundig Weekblad 1948, nr. $35, \mathrm{blz}, 282$

- Bouwkundig Weekblad 1948, nr. $35, b l z \cdot 286$

- Protest tegen de 34 millioengulden honorarium, Bouwkundig Weekblad 1949 , nr. 17 , blz. 181

- Bouwkundig Weekblad 1949, nr. 19, blz. 307 
IV. 5

VERVOLG NOTENLIJST

18. Prot. dr.

J.N. Bakhuizen

van den Brink

- "De Architektenwet" , Bouw 1949 II, bIz. 640

19. mr. W.C.S. Laman Trip - De Architektenwet en de aannemerswereld, Bouw 1949-II, blz. 172

20. ir. J.H. Alberda

- Autoriteit of Knecht? Bouw 1949-II, blz. 883

21. A.D. $\operatorname{van}$ ECk

22. Priedhoff

van der steur

23. dr. A. Henkemans

- Bouw 1949-II, blz. 551

- Perspectieven ener Samenwerking tussen architect en ondernemer. Bouw 1950, b1z. 23 e.v.

24. dr. A. Henkemans

- Nationale armoede en architectuur. Bouw 1950, blz. $4: 2$ e.v.

25. A.J.C. Horstman

- De architect vrij van directievoering? Bouw 1951, bl z. 187

26. ir. W.W. van Tijen

- De architect als ontwerper voor bouwbedrijven, Bouw 1953, blz. 42 e.v.

27. ir. W.W. van Tijen - Bouw 1953, blz. 43

28. ir. A.J. van der steur - Plats en betekenis van de architect. Bouw 1953, blz. 13 e.v.

29. ir. H.M. Buskens

- "Architect moet zijn nieuwe positie begrijpen en anvaarden", Bouw 1958 , blz. 543

30. Ir. H. Lammers

- Bescherming van titel en beroep, Bouw 1958 , blz. 542

31. Prof Sibil Moholy-Nagy - Architectuur - kunst of constructie? Bouw 1959-I, ble. 304

32. Mr. H.O. Thunnissen

- Architectentitel, Bouw 1959, blz. 554

33. dr. C.H. van der Leeuw - Bouwheer en Bouwmeester Bouwkundig Weekblad: 1961 nr. 17 blz. 347

3.4. dr. J. Pen

- Economische groei. woningbouw en marktmechanisme, Bouw 1962 blz. 1138

35. G. Werkman

- De Nederlandse architect en zijn bureau, Bouw 1962, bIz. 1206

36. G. Werkman

- Bouw 1962, blz. 1206 
IV .5

VERVOLG NOTENLIJST

37. Henry Mintzberg

- The structuring of organisations. Fin. Dagblad februari 1985

38. 1r. A.J. van der steur - Het krachtenspel in de driehoek. Bouw $1963-\mathrm{I}$, blz. 662

39. A. Leyten

- Naar nieuwe vormen van samenwerking, Bouw 1963-I, blz: 669

40. A. Leyten

- idem, blz. 670

41. H. Van Eesteren

- Geen "Wildverband" mar gecoordineerde samenwerking, Bouw 1963, b1z. 671

42. Th.H. Oltheten

- De spanning van het avontuur, Bouw 1963 , blz. 667

43. ir. A.J. van der steur - De positie van de architect, Bouwkundig weekblad 1963 , nr. $11, \mathrm{blz} .175$

44. ir. J. van Santen

- Problemen bij de groei van het architectenbureau. Bouw 1964 , blz. 948 e.v.

45. ir. P. Mulder

- De verantwoordelijkheid van de architect. Bouw 64, blz, 230

46. A. van Haaren

- De verantwoordelijkheid van de architect voor de kwaliteit van het bouwen. Bouw 1964, b1z. 803

47. Bouwkundig Weekblad

$-1964, \mathrm{blz} \cdot 18$

48. Bouwkundig Weekblad

- 1964, blz. 19 e.v.

49. Bouw

50. dr. ir. A. Twijngtra

- 1965, blz. 1419

- Kostprijsberekening Bouw 1966, blz. 715

51. dr. ir. A. Twijnstra

- Bouwkundig weekblad 1967, nr. $B, b 1 z, 133$

52. dr. N. Eiedeldij Dop. - Bouw 1968, blz, 1053

53. Karel Brunne

- De vage beroepsituatie van de architectenstand. Bouw 1968, bl z. 244

54. prof. ir. W.J.G. van Mourik

- Vooruitgang in de ontwikkeling van de communicatie tussen architect en aannemer, Bouw 1968, blz. 754

55. J.A. V.d. Berg

- De architect als schijnvakman, BW $1968, b 1 z .353$

56. dr. ir. A. Twijnstra - Schaalvergroting en architecten, Bouwkundig weekblad $1969, b 1 z .412$ 
IV. 5

VERVOLG NOTENLIJST

57. C. Bekink

58. ir. A.E.O. Van Hezik

59. Horst Wanetschek

60. J.A. van den Berg

61. Dilck A. van Ruler

62. dr. A.L. Mok

63. ir. J. Cannegieter

64. Mr. Th.R. Bremer

65. Voorstel tot bescherming van de titel "architekt"

66. Wouter Smeulers

67. J. van Santen

68. prof. ir. M. Gout

69. Wan Duinen c.s.

70. H.W. Dijkgraaf

71. Kruijt en Twijnstra

72. ar. ir. A. Twijnstra

73. dr. ir. A. Twijnstra
- organisatiewormen van architectenbureaus, Bouwkundig Weekblad 1969, $\mathrm{n} r$. 14, blz. 420

- Hereniging architect-aannemer. voordracht voor de centrale werkgroep 28-03-1969 Bouwkundig Weekblad $1969, \mathrm{bIz}$. 421 e.v.

- Bouw 1969, blz. 1159

- Het verschijnsel architect 1970, Bouw 1970, blz. 817

- Het vije beroep verouderd of overleefd? Plan 1972, nr. 4, blz. 45 e.v.

- Professie en Arbeiasvoldoening:

uit Arbeidswoldoening en arbeidsbeleid, Markaboeken "Het spectrum" utrecht/ Antwerpen

- Beroepsuitoefening door architecten. Plan 1972, nr. 4, blz. 49

- De huidige betekenis van een erecode. Plan 1972, nr. 4, b1z. 50

- 1972, nr. 4,

- Plan 1972 nr. 4, blz. 53

- Veranderingen bij de architekt, Plan 1972, nr. 4, b1z. 32

- Plan 1971, nr. 2, blz. 62

- "Bouwen in de toekomst", rede TH - Delft 14-01-67

- Architekt en specialisatie, poging tot een typologie. Plan 1972, nr. 4, blz. 35

- Rechtgvorm van het architectenbureau. Bouw 1972 , -35 , blz. 1231 e.v.

- De interne organisatie van het architektenbureau in Nederland, Uitg. Samson Alphen aan de Rijn, Brussel 1973

- Strukturele veranderingen in de bouwnijverheid. Bouw 1973-8 blz. 249 e.v.

- idem, b.1z. 251 
IV. 5

VERVOLG NOTENLIUST

74. Joost de Klerk

75. Helga Eassbinder

76. Prof. dr. J. Hamaker

77. G. Werkman

78. W.M. Lookman

78. 't karregat

80. J. Kiers

81. SAB
- zouden architekten mensen zijn?

Bouw 1974, nr. 9, blz. 220

- Het architektenberoep. idee en werkelijkheid, Wonen TA/BK 1975-7

- De toeleverende funktie van de architect als bruggehoofd. Bouw 1977-20, blz. 564

- Bouw 1974-8, blz. 193

- Fin. Dagblad, sept. 1976 nr. 2,6 en 7

- Scholengemeenschap Eindhoven arch. F. van KIingeren

- Bouw 1977-22, blz. 602 e.v.

- Vereniging van samenwerkende Stedebouwkundigen Architekten en Bouwtechnische Adviseurs een samenwerkingsverband in het administratieve vlak

82. Prof. W.G. Quist

- Bouw 1978-25, blz. 15

83. drs A.W.F.J. Bakermans - Bouw 1978-17, blz. 27

84. Bouwpraduktie haudt. hetzelfde niveau

- Bouw 1979-22, blz. 210

85. Architectenbureaus blijven achter met hun rendementsontw.

86. ir. P. Mulder

- Bouw 1979-7, blz. 16

- Bouw 1980, nr. 9

- Bouw 1980-12, blz. 22

- Bouw 1981-4, blz. 6

- Bouwnijverheid in Europa, Bouw 1981-16

- Bouw 1981-24 blz. 19

90. De bouw in de jaren 80

91. Eenmaling effekt stimuleringsprogramma - Bouw 1982-4, blz. B

92. dr. A.G. ter Hennepe

93. dr. Roest

94. BNA Jaarverslag 1981

95. Prof dr. G.E. Engberts

96. drs. R.J. de Wit

97. Alexander Tzomis Liane Le Faivre

98. ir. P.A.M. Mertens
- Bouw 1984-9, b11z. 20

- Bouw 1982-16, b1z. 17

- Bouw 1982-19, blz. 6B

- rede op 30 september 1982 te Broek op Langedi jk

- Vragen over de toekomst van de architekt, Bouw 1982-23, blz. 43

- Beroepsbeeld van de architect in de crisis, Plan 1983-6, biz. 10 
IV. 5

VERVOLG NOTENLIJST

99. G. Gerritse

- Innovatie in het architektenvak. Plan 1983 nr. 5, blz. 26

100. Knapper en MCAlley BV - De architect in de jaren " 80 , juni 1983 (rapport)

101. dr. ir. J.J. Kroon

- Architect en publiek als konkurrenten. Financieel Dagblad $03-10-83$

1.02. "Bouwcontouren"

- Bouwwerela 1984-23

103. "De Elite"

- Uitgeverij stylas 1970. bl $z, 13$

104. "De Elite"

- Uitgeverij stylos 1970, blz. 5 e.v.

105. Herstruktureringsnota

106. "Tobpunten van wetenschapsbeleid"

107. prof. ir. M. Gout

108. BNA

109. BNA

110. STC

- afd. Bouwkunde Delft 1972

- THD Delft, juni 1976, blz. 59 e.v.

- "De Bouwadviseur" " mel 1985 nr. 5, blz. 85

- enquete werkgelegenheid 1983

- Rapport "Begintermen Beroepsuitoefening Architekt" mart 1985

- rapport Ministerie van onderwijs en wetenschappen, 1985 inzake Schaluergroting Taakstelling en concentratie in het onderwijs 
DE JURIDISCEE IMPLIKATIES VAN HET VERSCHUIVEND

MAATSCHAPPELIJK BEELD 1945-1985

V.1 De kontraktuele relatie opdrachtgever-architekt

V.1.1 De $A^{*} 71$ in samenhang met voorgaande

V.1.1.1 algemeen

V.1.1.2 algemene bepalingen van de $A R$

V.1.1.3 werkzamheden van de architekt/omvang van de opdracht

V.1.1.4 honorering van de architekt en vergoeding van zijn kosten

V.1.1.5 toezichthoudend personeeel/adviseurs

V.1.1.6 verdere verplichtingen van de architekt

V.1.1.7 aansprakelijkheid van de architekt

V.1.1.8 bevoegdheden van de architekt bij het voeren van direktie

v.1.1.9 bijzonder verloop van een opdracht

V.1.1.10 geschilien

V.1.2 de SR. 87

V.1.2.1 de totstanakoming van de SR'87

V.1.2.2 globale aanduiding van de belangrijkete

ontwikkelingen in de SR"87 t
V.1.2.3 de SR"87 - een nieuwe koers?

V.2 De belangrijkste juridische diskussiepunten

V.2.1 de vertegenwoordigingsbevoegdheid van de architekt

V.2.1.1 algemeen

v.2.1.2 bij de planontwikkeling tot aan de aanbesteding

V.2.1.3 bij aanbesteding

V.2.1.4 bij de uitvoering - direktievoering door de architekt

V.2.1.5 bij de eindafrekening

V.2.2 de honorering van de architekt volgens de $A R \cdot 71 / 183$

V.2.3 wanprestatie

V.2.4 prematuur werk

V.2.5 aansprakelijkheid

V.2.5.1 de aansprakelijkheidsregelen $1 n$ de $A R$ en $S R \cdot 87$

V.2.5.2 de exoneratie-clausules in de $\mathbb{A}$

V.3 Beslechting van geschillen 
W.3.1 beslechting via de AR

V.3.2 beslechting via bindend advies

v.3.3 beslechting via de rechter

V.4 Praktijkontwikkelingen rond 1987

V.4.1 de opdracht in het NBW

V.4.2 scheidslijnen in de planontwikkelingsfasen

v.4.2.1 de opdrachtgever

V.4.2.2 de architekt

V.4.2.3 de opdracht

V.4.3 koncentraties van partijen in de ontwerpfase

V.4.3.1 het bouwteam

V.4.3.2 het ontwerpteam

v.4.3.3 de ontwerper als kontraktpartij van de aannemer

V.5 Samenvatting

V.6 Notenlijst 
DE JURIDISCHE IMPLIKATIES VAN HET VERSCHUTVEND MAATSCHAPPELIJK BEELD

$V . \mathbb{1}$

De kontraktuele relatie opdrachtgever-architekt

V.1.1

De AR"71/' $B 3$ in samenhang met voorgaande regelingen (1932, 1956, 1964, 1969)

V.I.1.1

algemeen

Voor een vergelijking van de standaardregelen welke de rechtsverhouding tussen de (register) architekt en de opdrachtgever beheersen is uitgegaan van de regelingen welke sinds 1945 officieel zijn gehanteerd. Naar het tijdstip van vaststelling zijn dit de regelingen van 1932, $1956,1964,1969$ en 1971 . De AR'32 is tot 1956 van kracht geweest. Tussentijds zijn de regelingen steeds angepast qua honorering en tabellen, echter nauwelijks tekstueel. Bij de artikelsgewijze vergelijking is steeds de meest recente regeling, de $A R ' 71 /{ }^{\prime} 83$, als uitgangspunt gekozen, en deze, waar dat relevant is, gerelateerd aan de AR"32. Opgemerkt moet worden dat ten aanzien van de woningwetbouw en restauratie bijzondere regelingen gelden en golden, welke waren toegespitst op het specifieke karakter dat deze soort opdrachten kenmerkt. Veelal heeft dit betrekking op de omschrijving van de door de architekt te verrichten taak. Voor bouwwerken van het Rijk of die van Rijkswege gefinancierd worden is met uitzondering van woningwetbouw en restauratiewerken een Nadere Regeling van kracht. Voorts heeft de RK kerk enige jaren een verbijzondering gekend: de ARRK, waarin men zich voor enkele aspekten van de opdracht het nodige voorbehield.

voor een hanteerbare analyse van de standaardregelingen is uitgegan van de kern van de AR als zodanig, en zijn de afgeleide regelingen buiten beschouwing gebleven.

V.1.1.2

algemene bepalingen van de AR

Art. I - AR'32 geeft ten opzichte van $A^{\prime} 56$ een beperktere interpretatie van het begrip "architect" in die zin dat tot de specifieke kemmerken van het beroep behoort het geven wan adviezen in aangelegenheden "de boukkunst rakende" in plaats van het in AR" 32 genoemde "beroep 
rakende" De in dit artikel genoemde kwalifikatie "gemachtigde" heeft in de $A R^{\prime} 56$ e.w. de toevoeging gekregen "tenzij uitarukkelijk anders is overeengekomen".

Art. 2 - Geen wijzigingen.

Art. 3 - Verstrekking en aanvaarding van de opdracht $A R " 32$ : verstrekking zodra de hulp of voorlichting wordt ingeroepen of gewenst. anvaarding zodra de architect met de werkzamheden aanvangt, ook die welke "daruit voortvloeien". AR'56 e.v. leggen de architect de verplichting op om "duidelijk" te laten blijken dat deze dit als een opdracht beschouwt en dat hij die als zodanig aanvardt. Voorts dient een dergelijke opdracht door de architect schriftelijk te worden bevestigd, in de regelingen ná 1956 .

V.1.1.3

werkzamheden van de architekt/omvang van de opdracht

Art. 4 Specifikatie werkzamheden:

a. voorlopig ontwerp.

In AR 32 wordt gesproken van "tekeningen op kleine schaal", na 1956 is het voldoende om een voorsteliung van het bouwwerk te geven, al wordt gesuggereerd dat daarvoor als regel tekeningen zullen dienen die op kleine schaal getekend $2 i j n$.

b. uitvoerings- c.g. definitief schetsontwerp.

De $A R^{\prime \prime} 32$ spreekt van uitvoeringsontwerp, warmee bestektekeningen worden bedoeld. De verplichting om ter toelichting

tekeningen "op groter schaal" te produceren voor deze fase, bestond slechts indien zulks poor de a ambesteding noodzakelijk was, een en arider kenmelijk ter beoordeling yan de architekt. Er zij aan herinnerd dat de gegevensverstrekking door de architekt onderwerp was van felle kritiek van annemerszijde.

De $\operatorname{AR}^{\prime} 56$. V. gaan van een tussenstadium wit in de vorm van een definitief schetsontwerp.

De bestektekeningen worden na 1956 apart vermeld, alsmede de schaal warop zij 
moeten worden gemakt $(1: 100)$. Deze schal wordt trouwens door de meeste gemeenten woor het aanvragen van de bouwvergunning geëist. Bij deze bestektekeningen behoren na 1956 ook de werktekeningen ten behoeve van a anbesteding én uitvoering (AR'56 art. 4 sub e.). Na 1971 wordt daarin een splitsing gemaakt in werktekeningen nodig voor a anbesteding en die voor de uitvoering (AR'71/183 lia 4 sub $c$ en sub g). Waar de grens ligt is niet gedefinieerd en wordt derhalve een bron van konflikten. Men dient te bedenken dat het maken van werktekeningen enerzijds de werkgelegenheldssituatie op de bureaus bepaalt, en anderzijda een grote kostempost betekent voor de opdrachtgever.

Deze splitsing is mede veroorzaakt door het verschijnsel van onvolledige opdrachten aan de architekt, warbij de opdrachtgever anderen dan de ontwerpende architekt deze tekeningen doet verzorgen.

- Bestek: geen wijziging. Een "nauwkeurige" omschrijving van het werk en de uitvoeringsvoorwaarden wordt toereikend geacht.

- Begroting. Met de uitvoering van de AR'56 wordt nauwkeurig gedefinieerd hoe de begroting moet worden opgebouwd; terwijl statische berekeningen en hoeveelheidsberekeningen dienen voor de bestekomschrijving en vergunningaanvraag. Deze omschrijuing blijft verder tot 1987 onveranderd.

- Aabesteding. Behoudens een verduidelijking van de organisatorlache rol bij dit gebeuren, blijft de kern van dit opdrachtdeel ongewijzigd.

- Direktievoering. Met de AR ${ }^{n} 5$ wordt met name het bijhouden van de weekrapporten een architektenverplichting met daarbij de registratie van meer-en minderwerk. Het opmaken "zonodig" van betalings- en afrekeningsbescheiden (dus niet als verplichting) komt in deze regelingen voor.

Met de $\mathrm{AR}^{\prime} 71$ worden de "werktekeningen ten behoeve van de uitvoering" onder de 
direktievoering betrokken. Afgezien van twijels aan de juistheid van de rangschikking ontstat hiermee onduidelijkheid in verband met het vermelde onder $A R^{\prime} 71$ art. 4 sub $c$, immers, juridiach zou het $z$ wartepunt van de werktekeningen vóór de a anbesteding dienen te liggen teneinde onduidelijkheid in de kontraktstukken uit te bannen.

Zoals echter reeds eerder werd opgemerkt vertegenwoordigen de werktekeningen een grote onkostenpost voor de opdrachtgever. Deze zal sterk geneigd zijn eerst dan deze uitgave te doen wanneer er de grootst denkbare zekerheid is omtrent het slagen van de aambesteding, en dus van de uitwoering van het werk. Het belang van de aanbesteder is hier dus omgekeerd evenredig a an dat wan de a annemer. Wooral bij gesubsidieerde projekten, war een onberekenbaar lange wachtijid soms op politieke gronden wordt beëindigd, en versneld moet worden a anbesteed, komt het zwaartepunt geheel te liggen ná de aanbesteding, dat heeft technisch en esthetisch bezwaren. Enerzijds wordt fundamentele informatie bij de aanbesteding an de aspirantkontraktant onthouden. Anderzijds komt daardoor bij een onvolledige opdracht aan de architekt (warbij direktievoering niet wordt opgedragen) dit ook voor de juiste uitvoering van het ontwerp essentiële onderdeel, buiten de invloedssfeer van de ontwerpende architekt te liggen.

In de AR'71 wordt onder direktievoering tevens verstaan de kontrole en inpassing van tekeningen door derden vervaardigd. en het koördineren van alle werkaamheden. De vraag lijkt gewettigd of dat latste zonder onderscheid in omvang van het projekt ook in 1971 al van de architekt kon worden verlangd. Immers de differentiatie van disciplines had ook toen al voor omvangrijke projekten een zodanige wlucht genomen dat twijel an de juistheid van een zo ongenuanceerde regel op zijn plats moet worden geacht. Thans staat vast dat voor grotere werken het honorariumbestanddeel voor dit deel van de opdracht geheel ontoereikend is. 
"Let geven van leiding bij het houden van toezicht op de ultroering", hetgeen in alle regelingen tot de architektentaak behoort, is door de tijden heen een bron van konflikten geweest wanneer $z$ ich fouten in de uitvoering voordeden. Lange tijd is het zo geweest dat steeds de annemer als schuldige werd aangewezen, tenzij de architekt of zijn personeel aktief in de uitvoering had ingegrepen. De terughoudendheid van de architekt on zulks te doen heeft niet bijgedragen tot watdering voor zijn technische bekwamheid. De laatste jaren is er sprake van een kentering in de zienswijze van het arbitrageinstituut. De schuld van de architekt wordt darbij eerder aangenomen dan voorheen. Tot slot wordt in dit artikel in deze regelingen tevens de vertegenwoordigingsbevoegdheid van de architekt gesteld in alle zaken op de bouw betrekking hebbende". Wij zagen reeds in hoofdstuk II dat ook dit van meet af aan een zeer amstreden punt is geweest. In paragraaf $v .2$ wordt dit verder geanalyseerd voor de periode 1945-1985.

Veel misverstanden ontstaan door verwarring van direktievoering met dagelijks toezicht (CVG $1967 \mathrm{nr}$. 4, AIB $1071 \mathrm{nr}$. 18). Een dergelijke verwarring wordt vak veroorzaakt doordat, vooral. voor kleine werken, geen opzlichter wordt benoemd, maar de architekt tevens het toezicht verzorgt. AIB $1981 \mathrm{nr} .25$ legt wel een hoger kriterium aan voor direktievoering bij ontbreken van dagelijks toezicht.

- Eindoplevering. Kwam in de $A R^{\prime} 32$ niet voor. Voorzover het de revisietekeningen betreft waren die begrepen onder de direktievoering.

Eerst bij de AR'56 ligt de onvang van de verplichtingen vast bij beëindiging van het werk, deze worden daarna niet meer gewijzigd.

Art. 5 - De beperking van een gegeven opdracht tot de onderdelen genoema in artikel 4, wijzigt niet fundamenteel, behoudens de mogelijkheid: van samentrekking van voorlopig- en definitief ontwerp in de $A R$. 56, 64 en 69. In de $\mathrm{AR}^{\prime} 71$ vergchuift deze 
samentrekking naar definitief schetsontwerp in kombinatie met het gereedmaken voor a anbesteding (AR'7l lid c.).

In artikel 5 lid 3 wordt in de AR" $56 \mathrm{e} . \mathrm{v}$.

de verplichting op de opdrachtgever gelegd om, wanneer direktievoering en eindoplevering aan derden worden opgedragen, de architekt-ontwerper in stat te stellen op de uitvoering toe te zienten adviezen te geven. Aangezien in de AR 71 de werktekeningen hieronder mede begrepen zijn is dit 1 id niet zonder betekenis. Onbekend is of er poit naar gehandeld is, een

dergelijke verplichting is trouwens ook af te leiden uit de Auteurswet 1912 .

Het is overigens veelbetekenend dat reeds in de $A R$ " 56 kennelijk de noodzaak bestond om voor onvolledige opdrachten de rechten van de architekt veilig te stellen. Gezien de diskussies over de omvang van de architektenopdracht in vakkringen, ook in die tijd (zie hoofdstuk IV), is dit echter zeer verklaarbaar.

V.1.1.4

honorering van de architekt en vergoeding van zijn kosten

Art. 6-Klassificering van de opdracht. In de AR'56 is men tot het huidige systeem van Bijlagen overgegaan. Fundamenteel geen wijzigingen.

Art. 7 - Verdeling van het honorarium over de verschillende fasen van de opdracht. Wanneer men uitgaat van een architektenopdracht zonder direktievoering en eindoplevering dan verschuift het resthonorarium van 65. (AR'32) via 77,5\% (AR' 56, 64, 69) naar 75 in de AR'71. (AIB 1970 nc. 14).

Indien de architekt bemoeienis heeft gehad met enig onderdeel van de opdracht komt hem darvoor honorarium toe. Hieruit kan worden afgeleid dat artikel 7 id 2 niet van kracht is als anderen dan de architekt het betrokken onderdeel hebben verzorgd.

Art. 8 - Uitsluiting van de kosten van werktekeningen wit het honorarium, verrekening tegen of tegen werkelijke kasten, verplichting tot verstrekken van een kostenraming hiecvoor op verzoek van de opdrachtgever. Deze precisering is niet opgenomen in de $A R^{\prime 3}$, mat komt sinds de $A R$ " 56 onveranderlijk voor. In de AR" 32 is 
onder de werktekeningen ook "eenvoudig" konstruktiewerk in stal of beton begrepen.

Art. 9 - (AR"32 artikel 11). Grondslag voor de berekeningen van honorarium en werktekeningen, het begrip "bouwkosten". Ten opzichte van de $\mathrm{AR} 32$ is hetgeen tot de bouwkosten moet worden gerekend nader gedefinieerd in de AR'56, 64, 69 en 71 . Daarin zijn geen significante verschillen. De daarin begrepen "normale" technische installaties $z i j n$ in de $A R^{\prime} 71 / 183$ aanzienlijk scherper omschreven. Echter niet scherp genoeg om ook in 1971 diskussies over wat normal moet worden geacht te vermijden. Vooral in de late zestiger jaren is de technische out it van gebouwen snel geëvolueerd als gevolg van de ontwikkelingen in die sektor, wardoor het normkriterium snel vervaagde, met honorariumkonsekwenties als gevolg. De aftrek bij inschakeling van adviseurs op de konstruktie- c.q. installatiekosten verschuift $\operatorname{van} 331 / 3$ in de $A R^{\prime} 32,156$, ' 64 en '69, naar 20\% in de AR'71/'83. In feite is dat een omgekeerde reaktie op de opmars van andere disciplines in het bouwproces.

Voorts mag het verwondering wekken dat in de losse opsoming van posten die tot de bouwsom worden gerekend, niet het voorbehoud wordt gemaakt voorzover de architekt daarmee bemoeienis heeft gehad, dan wel deze posten in een bestek $z i j$ jn opgenomen. Het absoluut stellen zonder voorbehoud zou er toe kunnen leiden dat de architekt honorarium claimt voor zaken waraan hij part noch deel heeft gehad.

In de AR'7l wordt het de architekt toegestaan voor de bouwkosten zijn begroting a an te houden, wanneer hij de laagste inschrijfsom abnormal hoog acht, hetgeen een korting zou kunnen inhouden bij een voorkomende wanprestatie van de architekt.

Art. 10 - Terzijde stellen van konstruktieve werkzaamheden. (AR'56,"64,"69, 171/"83).

Art. 11 - Uitsluiting van werken onder een bouwsomminimum, wa arvoor een aparte overeenkomst diende te worden gesloten (AR'32 f $\left.3.000,-, A^{3} 56 \mathrm{t} / \mathrm{m} \mathrm{AR}^{\prime} 71-\mathrm{f} 10.000,-\right)$.

Art. 12 - (AR'32 artikel 10) Regeling van werken die 
onder verschillende klassen, regelen of bijlagen vallen. Uitsluiting van ontwerpwerk voor interieurbestanddelen onder verwijzing naar de speciale biljlage (niet in $\mathrm{AR}^{(32)}$.

Art. 13 - Regelingen voor samengestelde bouwopgaven, gefaseerde uitvoering van plandelen, herhalingsprojekten, seriebouw. Het artikel is voor het eerst opgenomen in de AR'56 en nadien niet meer gewijzigd.

Art. $14-\left(A^{\prime} 32\right.$ artikel 9). Toeslag van $30 \%$ voor verbouwingen en uitbreidingen met verbouwingsaspekten. Vanaf AR'56 onder het voorbehoud van verzwaring van de architektentaak.

Art. 15- (AR'32 artikel 13). De AR'32 voorzag slechts in de mogelijkheid van niet besteden naar een algemeen kontrakt van aanbesteding en liet het aan partijen over de verhoging van de percentages te bepalen als tegemoetkoming in het meerdere werk voor de architekt. De AR'56, "64, "69 en '71/'B3 vatten een aantal voor de architekt takverzwarende omstandigheden samen:

- analoog aan AR"32 artikel 13: meer dan één aambestedingskontrakt

- inschakeling van de aannemer op verzoek van de opdrachtgever lang voor de uitvoering wordt voor de architekt extra gehonoreerd met een toeslag van $20 \%$.

N.B.: dit kan niet anders worden gezien dan als een boeteclausule voor de instelling van een bouwteam, die noch in 1956 noch in 1971 stand kan hovden.

- Regie-apdrachten worden extra gehonoreerd met een toeslag van $27,5 \%, z$ Inde een verdubbeling van de percentages behorende bij a ambesteding, direktievoering en eindoplevering. Het is niet warschijniljk dat onder deze voorwarden veel regie-oparachten zullen zijn uitgevoera. 
Art. 16 - Samenwerking-ad-hoc met andere architekten, niet in een matschap of bureau-verbonden, op verzoek van de opdrachtgever. In alle regelingen is 30 verhoging van het honorarium vereist.

N.B.: hoewel veel bekritiseerd is deze regeling niet onlogisch. De samenwerking komt veelal onder pressie van de opdrachtgever tot stand vanwege vormgevingsaspekten. Dat heeft een extra belasting voor de "hoofd"-architekt tot gevolg welke doorwerkt tot de eindoplevering.

Art. 17 - Regeling voor één of meer varianten van het voorlopig ontwerp, bij gelijk bouwterrein en bouwprogramma.

De $A R^{\prime} 71 / 183$ spreekt van één of meer varianten. De eerste zonder, maar elke volgende met extra honorariumkonsekwenties, $t . w$. de helft van het honorarium voor voorlopig ontwerp AR" $32,156 \mathrm{t} / \mathrm{m}$ " 69 : bij meer dan twee varianten kan voor elke volgende variant $1 / 3$ van het honorarium voor voorlopig ontwerp in rekening worden gebracht.

Art. 18 - Honorering van herbesteding. Eén herbesteding in het honorarium begrepen, de volgende gehonoreerd. De regeling geldt vanaf AR'56, daarvoor was geen regeling voorzien.

Art. 19

lid 1 - Afzonderlijke honorering van door de opdrachtgever verlangde wijzigingen, ook wanneer deze door de architekt worden geInitieerd, ook wanneer deze wijzigingen noodzakelijk zijn om tot gunning te komen, onverlet het bepaalde in artikel 3l. Deze regeling komt in eerdere AR's voor onder artikel 19 lid 1 , sub b (AR'56 t/m "69). Komt niet voor in de AR' 32 .

Art. 19

1 id 2 - Het bouwwerk komt niet tot uitvoering. Wanneer er werkzamieden $z j$ jn verricht, worden deze afzonderlijk gehonoreerd naar de Regelen inklusief verschotten e.d. Ongewijzigd sinds AR'32 (artikel 16) en 1956 (artike1 19 1id 2).

Art. 19a- Extra honorering van werkaamheden wan het eisenprogramma. Alleen als dit door de opdrachtgever gedurende de gehele voorbereiding en/of bouw platswindt in 
samenwerking met derden wordt gewenst, moet daran een aparte, tevoren gesloten overeenkomst ten grondsiag liggen. In overige gevallen is de extra honorering een feit zonder meer.

De in hoofdstuk IV gesignaleerde explosieve ontwkeling in de organisatie van grote opdrachtgevers in de 2 e helft van de zestiger jaren, makte het roor deze vrijwel ondoenlijk on een sluitend programma op te stellen. Vóócilen kon de architekt hem daarbij behulpzam zijn. later werd dit meer en meer verweven met managementsproblemen en komt de organisatieadviseur er aan te pas. Het probleem overstijgt de discipline van de architekt, hoewel deze niet off-side kan blijven staan: hij ontwerpt immers voor de gebruiker in de ruimste $z$ in. Hoewel het niet onbegrijpelijk is, lijkt het toch niet verstandig om daarvoor extra honorering af te dwingen. De kans om buiten spel gezet te worden in één van de meest essentiele fasen van het ontwerpproces wordt daarmee zeer groot. Dat is ook valk gebeurd. Deze regelling komt ook voor in AR'56," 64 , '69 (artikel 19 1id 1 sub a).

Art. 20 - Verschotten regelingen ( $A R^{\prime} 32$ artikel 17). In essentie niet gewijzigd. De in AR' 32 artikel 17 sub c opgenomen regeling voor het maken van de revisietekeningen blijft eveneens ongewijzigd.

Art. 21 - Voorbereidend onderzoek en allerlei bijzondere werkzamheden. Honorering via bijzonder tarief. Niet gewijzigd sinds $A^{\prime}$ ' 32. zij het dat deze bijzondere werkzaamheden in de AR"7l meer met name worden genoemd.

Art. 22 - Minimum tariefstelling voor bijzondere bemoeienissen, de hoogte van de tarieven is in de tija a angepast.

Sinds de $A R^{\prime} 56$ dient de architekt aan de opdrachtgever mede te delen wanneer hij een hogere honorering dan het minimum wenst. Die voor taxaties, jurering e.d. volgens. apart te sluiten overeenkomst, ongewijzigd sinds AR" 32 .

Art. 23 - Honorering naar bestede tijd. Deze honoreringswijze is geintroduceerd bij AR'56, nadien niet gewijzigd. De totalkasten mogen nooit lager zijn dan de 
honocering via de regeling in de tabellen van de Bijlagen (dus wel hóger), terwijl de kosten wan de architektenuren gelijk, of meer, moeten zijn dan die van $z i j n$ personeed, vermeerderd met de gebruikelijke bureautoeslag. Een clausule ter voorkoming van werken onder de markt. Men kan zich afvragen of een standara regeling gebruikt moet worden ter bestrijding van oneerlijke konkurrentie.

Art. 24 - Tijdstippen van invorderbarheid van het honorarium, renteclausule.

De staffeling van de werkzaameden is van de AR" 32 ten opzichte van de darna volgende verschillend, mar de invorderingstermijnen verschillen niet fundamenteel. Achterstand in betaling makt rentevordering mogelijk. AR'32: 58 vanaf de dag der invorderbarheid. AR'56 t/m 69: promessodisconto DNB + $11 / 28$ vanaf 2 manden na deklaratiedatum. AR'71/183: wettelijke tente volgens $1286 \mathrm{BW} / 1804 \mathrm{BW}$ na 2 maanden.

Uit de BNA-enquête (* 1) blijkt ten aanzien van de rentevorderingen dat slechts in $20 \%$ van de gevallen rente in rekening wordt gebracht, daarvan wordt $30 \%$ betaald, terwijl 418 van de ondervraagden te kennen gaf dat er druk werd uitgeoefend om de desbetreffende nota's terug te nemen. Uit dezelfde enquête blijkt dat bij Rijksopdrachten na 2 manden slechts $37 \%$ van de nota"s is voldaan. (Provincie 78\%, gemeente 64\%, overigen 64-88\%).

Art. 25 - Vertragende omstandigheden welke redelijkerwijs de architekt niet kunnen worden aangerekend. Vergoeding van schaden en kosten als gevolg van het oponthoud. In de $A R^{\prime} 32$ is bovendien nog sprake van een rente-vergoeding van 5 z jaara. In de $\mathrm{AR}^{\prime} 56$ e.v. vervangen door vergoeding nar billijkheid.

Na de $A R^{\prime} 56$ regelt lid $z$ van dit artikel de mogelijkheden tot afrekening na een oponthoud van langer dan 2 maanden.

Art. 26 - Tijdstip van vastelling van de definitieve grootte van het honorarium pas na de gehele beëindiging van de werkzaamheden. AR' 32 artikel 22 geeft de mogelijkheid aan van een percentsgewijze vermindering van honoraria en werktekeningen. Dat was gemeente- of 
streekafhankelijk en kon slechts door het Bestuur an de BNA worden vastgestela. Een dergelijke vermindering moest echter bij opdracht tussen opdrachtgever en architekt zijn overeengekomen. Met de AR'56 e.v. verviel deze mogelijkheid.

Art. 27 - Regeling van omzetbelating c.q. BTw na de $A R=56$.

V.1.1.5

toezichthoudend personeel/adviseurs

Art. 28 - Regeling arbeidsverhouding toezichthoudend personeel. In essentie sinds $A R^{\prime} 32$ niet gewijzigd. In de latste 10-tal jaren komt het steeds vaker voor dat de opdrachtgever eigen opzichters in dienst heeft, of voor het werk in dienst neemt, hetgeen uiteraard juridische konsekwenties heeft omdat daarmee de ansprakelijkheid van de architekt vervalt, tenzij hij de kwaliteit van het personeel accepteert, al of niet stilzwijgend.

voorts een regeling voor de vergoeding van toezlchtkosten en emolumenten:

renteclausule.

De regeling wan de betaling van de met het toezicht gepard gaande kosten is met de AR" 56 verfijnd en verduidelijkt, maar in essentie niet gewijzigd.

Art. 29 - Adviseurs voor konstruktie, installaties e.d. valien niet onder de standaardregeling, de opdrachtgever is voor de honorering rechtatreeks aansprakelijk jegens de betrokken adviseur. Sinds de AR' 32 niet gewijzigd.

Dit artikel heeft de vervreemding van de architekt van de overige mede-planbepalende disclplines in de hand gewerkt. Met de groej van de bij de bouw betrokken specialismen na 1965 is deze beweging nog versterkt. Daardoor is de matschappelijke positie van de architekt ten opzichte van de opdrachtgever in toenemende mate verzwakt. Hij kan niet langer worden gezien als de figuur die de totaliteit van het bouwproces beheerst. Hij ontgaat de verantwoordelijkheid en de aansprakelijkheil voor de "aangrenzende" disciplines. 
V.1.1.6

verdere verplichtingen van de architekt

Art. 30 - Verplichting van de architekt de eisen van de opdrachtgever met betrekking tot het plan te realiseren, tenzij hij deze niet te verwezenlijken acht. In dat laatste geval dient hij de opdrachtgever daarop te wijzen.

Uitsluiting van de esthetische warde van het projekt bij de beoordeling wan de architektenprestatie.

Sinds de $\mathrm{AR}^{\prime} 32$ is deze regel niet gewijzigd.

Art. 31 - Wanneer geen bouwsom is genoemd bij opdracht, kan er geen sprake zijn van overschrijding.

Wanneer dat wel het geval is mogen de kosten van uitvoering bij anbesteding niet met meer dan $20 \%$ worden overschreden. Is dat wel het geval dan moet het ontwerp zonder vergoeding door de architekt binnen die marge worden aangepast. Blijkt dat niet mogelijk dan verbeurt hij het honorarium voor het besteksgereed maken. In beide laatste gevallen alleen niet als hij aantoont dat een en ander te wijten is aan omstandigheden buiten zijn verantwoordelijkheid. Miet gewijzigd sinds AR"32.

Art. 32 - De verplichting voor de architekt om rekening te houden met privaatrechterlijke- en publiekrechterlijke voorschriften welke bij architekten algemeen bekend mogen warden geacht. Niet gewijzigd sinds $A R ' 32$.

V.1.1.7

a ansprakelijkheid van de architekt

Art. 33 - Aansprakelijkheidsbeperking van de architekt, of zijn personeel, voor schade tot "ernstige fout", tenzij deze antoont dat zij bij normale oplettendheid en vakkennis niet had kunnen worden vermedem. In de $A R \cdot 32$ wordt hieraan toegevoegd "zulks voorzover nodig in afwijking van het gestelde bij 1645 BW". Deze zinsnede komt in de $A R^{\prime} 56$ e.v. niet meer woor. Het terzijde stellen van 1645 BW is overigens onjuist wanneer $1645 \mathrm{BW}$ van openbare orde. is. Die vraag is lang een juridisch strijdpunt geweest en is dat nog steeds, de voorstanders zijn echter in de meerderheid. 
Voor de diskisie hieromtrent radplege men prof. mr. M.A. van Wijngaarden hoofdstuken Bouwrecht nr. 2 blz. $19 \mathrm{e} . \mathrm{v}$. en woor de relatie van de architekt met 1645 BW, idem blz. 14 e.v.

(zie ook hoofdstuk III).

Art. 34 - schaderegeling. Beperking of ongedaan maken van schade voor eigen rekening. Exoneratie clausule, beperking tot helft van het honorarium. Verval van aansprakelijkheid na 10 jaar vanaf le oplevering. Deze regeling geldt vanaf de $A R$ "56. In de AR" 32 wordt de schade beperkt tot het gehele honorarium en vervalt de aansprakelijkheid na 3 jaar vanaf de eerste oplevering.

In de AR'32 artikel 29 wordt gesteld dat de architekt niet a ansprakelijk is voor tekortkomingen van personen in zijn dienst, indien hij a annemelijk makt dat hij de tekortkoming bij normale oplettenheid $z i j n e r z i j d s$ niet had kunnen opmerken of ontdekken. Dit artikel is een afwijking van $1403 \mathrm{BW}$ en komt niet meer voor in $A R^{\prime} 56 \mathrm{t} / \mathrm{m}$ 71. Of dat het gevolg is van deze afwijking is niet duidelijk. Er zal immers niet altijd sprake zijn van onrechtmatige daad.

Art. 35 - Vrijwaring van de architekt voor aansprakelijkheid voor door derden ontworpen onderdelen, zowel voor ontwerp als uitvoering, echter met uitzondering van het bouwkundig inpassen van deze onderdelen in het bouwwerk. Komt in engere $z$ in voor in $A R ' 32$ artikel 30. Gelijkluidend in $A R^{*} 56$ $\mathrm{t} / \mathrm{m} 71$. AIB $1984 \mathrm{nr} .8$.

Art. 36 - lid 1: vrijwaring van a ansprakelijkheid van de architekt voor schade als gevolg van handelen van derden in strijd met tekeningen, bestek etc. Identiek sinds $A^{\prime}$ ' 32 AR'7l vaegt toe: "behoudens de ansprakelijkheid van de architekt terzake van het voeren van direktie"). 1id 2: nieuw is in $A R^{\prime} 71$, dat vam vergoeding van schade door de architekt eerst sprake zal zijn indien en voorzover de opdrachtgever aantoont dat het geleden vermogensnadeel niet verhaald kan worden op aannemer of leverancier.

lid 3: bij doordrukken van de opdrachtgever van risikogevende participanten in het bouwproces; is de architekt niet verplicht 
tot schadevergoeding mits hij schriftelijk gewarschuwd heeft.

V.1.1.8

bevoegdheden van de architekt bil het voeren van direktie

Art. 37 - Bevoegdheid tot het eigenmachtig aanbrengen van wijzigingen bij de uitvoering, ook uit esthetische overwegingen, binnen het kader wan de post onvoorzien, danwel 2 van de bouwsom. Onveranderd sinds $A R ' 32$ (artikel 34).

Men kan de mening aanhangen dat elke financièle konsekwentie in het kader van de direktievoering ter kennis van de opdrachtgever moet worden gebracht, ook als deze ten laste komt van een gereserveerde post onvoorzien. Het valt niet goed in te zien waarom daarover geen owerleg nodig zou zijn. In het huidige organisatiepatroon van de uitvoering komt echter meestal ook de opdrachtgever voor, zodat deze vanzelf kennis neemt van deze uitgaven of daarin mede beslist.

Art. 38 - 1id 1: definitie "meerwerk" (AR'32 artikel 35 "bijwerk"). Identiek sinds AR" 32 .

1id 2: definitie "bijgekomen werk" (AR"32 art. 36). Identiek sinds $\mathrm{AR}^{\prime} 32$. lid 3: bevoegdheid tot het opdragen van meerwerk binnen de post onvoorzien of $2 \%$ van de bouwsom zonder goedkeuring van de opdrachtgever. Geldt niet bij overschrijding van de aangegeven grens of voor bijgekomen werk in het algemeen. lid 4: overtrekken wan genoemde bevoegdheid is voor rekening en risiko van de architekt, tenzij sprake is van spoedeisende matregelen, of zoals deze "van nut" is voor de opdrachtgever. Deze regeling is sinds $A R^{\prime} 56$ onveranderd.

Art. 39 - Bevoegdheid van de architekt tot beoordeling van de uitvoering van de a annemingsovereenkomst en van afgifte van betalingscertifikaten. Geen wijziging sinds AR'32.

V.1.1.9

bijzonder verloop van een opdracht

Art. 40 - Herroeping van de gegeven opdracht. AR' 32 onderscheidt 3 gevallen (AR' 32 
artikel 38).

a. Herroeping zonder meer. De opdrachtgever is verplicht het gehele honorarium te voldoen, als ware de gegeven opdracht uitgevoerd, benevens alle overige kosten (werktekeningen) tot dat tijastip gemaakt.

b. Herroeping als gevolg wan omstandigheden buiten de 11 van de opdrachtgever (bewijslast), of tengewolge van

"handelingen" van de architekt etc. De opdrachtgever is verplicht het honorarium te voldoen woor alle onderdelen tot het moment van herroeping benevens alle overige gemakte kosten.

c. Herroeping als gevolg van wanprestatie van de architekt. De opdrachtgever is geen honorarium en kosten verschuldigd voorzover deze voor hem niet van nut $z$ ijn, ongeacht zijn uit deze Regelen voortvloeiende ansprakelijkheid.

AR'56, '64," 69 en '71. De verplichtingen ad a. vervalien. De andere gevallen blijven onveranderd bestaan. AR'71 artikel $4011 d 1$ en 2 . AIB 1985 no. 12 , AIB 1985 no. 8 BR 1986 blz. 71 .

Art. 41 - Beëindiging van de opdracht als gevolg van bijzondere omstandigheden.

AR'32 (artikel 39).

a. dood van de opdrachtgever leidt niet tot beëinaiging.

b. besluit tot ontbinding van de opdrachtverlenende rechtspersoon betekent herroeping van de gegeven opdrachten.

c. verlies van cechtspersoon van de opdrachtverlenende instantie betekent herroeping van de gegeven opdracht. AR $56,164,169,171 / 183$. De mogelijkheid ad c vervalt, voor het overige geen wijzigingen.

Art. 42 - Neerleggen van de opdracht doot de architekt.

AR'32 (artikel 40) drie gevallen.

a. neerlegging zonder meer. Geen honorarium en verdere kosten en onkostenvergoeding voor de architekt.

b. de architekt toont aan dat een en ander te wijten is a an omstandigheden buiten zijn wil of aan "handelingen" van 
zijn opdrachtgever. Wel honorarium yoor reeds verrichte arbeid, alsmede kosten en onkosten.

c. wanprestatie van de opdrachtgever.

Deze is hem volledig honorarium over de gehele opdracht verschuldigd alsmede alle kosten en onkosten.

In de $\operatorname{AR}^{\prime} 56,164$, '69: zijn de leden a en $b$ in omvang niet gewijzigd, lid b omkering van de bewijslast.

Lid c leidt niet tot vardering van het gehele honorarium maar alleen voor die onderdelen van de opdracht die latstelijk aan de orde waren, niet alle kosten en onkosten.

$A R^{\prime} 71$ a ongewijzigd, b ongewijzigd t.o.v. $\mathrm{AR}^{\prime} 69$, c ongewijzigd t.o.v. $\mathrm{AR}^{\prime} 69$.

N.B.: sub b en sub c zijn in de AR'71

samengetrokken tot één 1 id (artikel 42 ijd 3).

In de AR'71 is een nieuw lid opgenomen (artikel 42 lid 2) warin twee bijzondere gevallen aan de orde zijn.

d. de architekt onttrekt zich aan het voeren van direktie zonder gegronde reden en de opdrachtgever neemt deze talak over

e. de archiltekt legt de opdracht neer als gevolg van bijzondere omstandigheden. In beide gevalien behoudt de architekt het recht op honorarium voor reeds verrichte arbeid en vergoeding van kosten en onkosten.

Het doet eigenardig aan dat wanprestatie van de architekt als onder $d$. hetzelfde effekt sorteert voor de opdrachtgever als de overmacht onder b., ervan uitgaande dat de opdracht nit beperkt was tot het bestedingagereed maken. Men zou daruit kunnen konkluderen dat de ontwerper minder gekwalificeerd zou zijn voor de uit voering. 
Art. 43 - Beéindiging door de dood van de architekt.

AR'32 (artikel 41) de gegeven opdracht vervalt.

Gevorderd kan worden door de erfigenamen:

- het vervallen mar nog niet uitbetalde honorarium

- honorarium en kosten van gemakte werktekeningen

- gemakte kosten en onkosten. Toestemming van de erfgenamen is nodig voor de uitvoering of verdere uitvoering van het ontwerp.

AR'56, '64, '69,'71/'83. De financiële verplichtingen van de opdrachtgever $z i j n$ onveranderd. Sinds $\mathbb{1 9 5 6}$ is ten aanzien van de opvolging van de overledene het volgende bepaald: de opdrachtgever overlegt met de erfgenamen over een andere architekt. Wanneer hiervoor binnen 1 mana geen oplossing is gevonden, volgt aanwijzing door het BNA-bestuur. Zulk een aanwijzing is bindend. Na zijn benoeming pleegt de opvolgende architekt met erfgenamen en opdrachtgever overleg over de financiële afwikkeling van het dan gereed $z$ ij jnde deel van het werk. Wederom wordt, wanneer niet binnen 1 maand overeenstemming bereikt, een bindende uitspraak gedaan door het BNA-bestuur.

Art. 44 - Eigendomsrechten AR"32 t/m AR'71.

Geen wijziging.

Art. 45 - Auteursrechten - vervelvoudiging

Nast de bepalingen van de Auteurswet 1912 is voorzien in een regeling voor het geval de architekt weigert direktie te voeren voor een aanvaard ontwerp, of deze direktievoering neerlegt. In dat geval is de architekt verplicht tot overdracht van het recht tot uitvoering (na de AR'56 - "om niet"). De AR"32 voorzag nog in een dergelijke verplichting wanneer erfgenamen van een overleden architekt uitvoering van een ontwerp weigerden. Deze bepaling kwam te vervallen door de verbeterde opvolgings-regeling van de AR"56 e.v.

De AR'7l breidt deze regeling uit tot alle gevallen welke in deze AR zijn benoemd en die slaan op de beëindiging van de opdracht tijaens of vö́r de uitvoering. Indien zulks over en weer op gegronde redenen is gebaseerd, dient de architekt in stat te worden gesteld de uitvoering te volgen en adviezen te verstrekken. Een en ander resulteert voor de opdrachtgever in een extra toeslag van 5 over het totale honorarium van voorlopig ontwerp tot en met aanbesteding, en de adviezen nar bestede tija met een grens van 15 : van het totale honorarium. Deze regeling geldt 
niet in geval van surseance of faillissement ven de architekt.

Art. 46 - Plaatsing van naam of naamteken op het werk. Geen essentiele wijziging sinds AR'32.

AIB 1969 nr. 1 .

V.1.1.10

geschillen

Art. 47 - AR'32, artikel $45 \mathrm{t} / \mathrm{m} 50$ :

- primair minnelijke schikking via deskundige

- daarna verwijzing nar scheidsgerecht (Commissie van Geschillen)

- uitspraak scheidsgerecht als goede mannen nar bilijkheid overeenkomstig het Reglement

- uitspraak is bindend advies.

AR'56 $t / m \cdot 71$ :

verwijzing nat Commisie van Geschillen c.g. Arbitrage Instiuut Bouwkunst.

Op 1 januari 1969 is de Commissie van Geschillen BNA opgevolgd door de stichting Arb. Inatituut Bouwkunst.

$V \cdot 1.2$

de $S R \cdot 87$

V.1.2.1

de totstandkoming van de SR'B7

Reeds tamelijk kort voor de invoering van de AR' 64 , werd men zich bewust dat de matschappelijke ontwikkelingen zoals aangeduid in hoofdstuk IV.2.2 een standaardregeling vereisten welke de wederzijdse belangen van de kontrakterende partijen beter tot haar recht deed komen. In 1967 werd met de ontwikkeling van de nieuwe regeling begonnen.

op 7 juni 1967 ging de "Commissie Herziening Honorarium" (CHH) van start, na daarvoor op 29 mart 1967 van het BNAbestuur opdracht te hebben gekregen, on te komen tot een nieuwe opzet van de standaardregeling (zgn. Comisisie SR). op 16 december 1968 bood deze Commissie had rapport a an het Dagelijks Bestuur van de BNA an. In de a anbiedingsbriet stelt de voorzitter ir. F. W. de Vlaming dat de Commisile niet heeft getracht de bestaande regeling op een antal punten bij te werken, maar dat zij getracht heeft de stof geheel opnieuw te bekijken en daarbij afstand te nemen van de bestaande regeling.

De Commissie heeft daarbij een antal problemen ontmoet warvoor zij geen pasklare oplossing heeft kunnen vinden. Men heeft zijn taak gezien als het aangeven van een antal hoofdstukken ter nadere verwerking. Er ontbrak nog veel aan 
evenulichtigheid en homogeniteit, terwijl men zich nog meermalen bepalde tot het stelien van problemen (* 2 ). In de Commisie zelf bestond nog verschil van mening "over principiële punten. samenhangend met de rol die men de architekt in de samenleving toedenkt".

De vitgangspunten van de "nieuwe $\mathrm{AR}^{\text {* }}$ vormden (* 3 ):

- wijziging in de werkmethodiek van de architektenbureaus en veranderingen in de architektuurproduktie, alsmede in het karakter van de opdrachten

- wijziging in de teneur van de intermatachappelijke relaties die de verhouding architektenbureau-opdrachtgever niet ongemoeid laten

- het beward en gereserveerd blijven van "de klassieke" adviseurgwerkwijze van de architektenbureaus.

Vermeldensward is de brief die de voorzitter van de cHH aan het Bestuur van de BNA zond op 21-07-1969, waarin hij gewag makte van opmerkingen die individuele leden van de Comnisie hadden gemaakt. Zij hadden alle betrekking op de matschappelijke positie van de architekt en zijn

rechtsverhouding tot de opdrachtgever, zoals:

- no cure no pay via jointventures warbij de architekt mederisikodrager is

- bouwlkundige intenties c.q. produkties met winstoogmerk op elgen initiatief "met octrooi-achtige" wijze van exploitatie

- sales-promotion "mits de konkurrentie binnen redelijke grenzen blijft en de uitvoeringskwaliteit kan worden gewaarborgd"

- uitbreiding van het ondernemerschap van de architekt tot "general contract", inklusief bouwvoorbereiding,

kongtrukties, technigche installaties en uitvoering, met de daarbij behorende verantwoordelijkheden en aansprakeli jkheden.

Hiermee was de Commissie har tijd ver vooruit. De hoap die in de brief wordt uitgesproken, dat daarmee een bijarage werd geleverd voor verdere ontwikkelingen, bleek helaas i. jde 1 .

De erste koncept-sh werd op 03-11-1970 aan de BNA-leden aangeboden. De CHH werkte tot 1973 an het eerste koncept, warna een "Nieuwe Commissie SR" er verder aan werkte tot 1976. Dit leidde tot het $\mathrm{zgn}$. Tweede Koncept SR. Vanaf augustus $1980 \mathrm{kwam}$ het overleg op gang met de vertegenwoordigers van de Ministeries en de Rijksgebouwendienst onder voorzitterschap van Mr. H.O. Thunnissen; hetgeen leidde tot het Derde Koncept $\$ R^{\prime} 85$.

De grate rol van de Rijksoverheid bij het koncipiëren van de nieuwe standaardregeling steunde op het uitgangspunt van de BNA dat hierop bij voorbaat een akkoord moest $z i j n$ verkregen door deze Rijksoverheid als grootste opdrachtgever. Zulks ter voorkoming van het ontstaan van allerlei nadere regelingen als afgeleide van de nieuwe standararegeling. 
In april 1985 werd uiteindelijk binnen de werkgroep

Thunnissen overeensteming bereikt, niet alleen over het tekstuele gedeelte mar tevens over de daarbij behorende tabellen voor de honorering. Voaral dat laatste heeft sterk vertragend gewerkt: het bewijs diende te worden geleverd dat daarmee geen verhoging van de tarieven werd bereikt, een bewijs dat met de theoretische aanscherping van de architekten prestatie, zoals die in de tekst is verwoor, nauwelijks te leveren is.

Juist op het ogenblik dat alle partijen in de werkgroep darover overeensteming hadden bereikt, werd de ratificering van het akkoord door de verschillende betrokken ministeries verhinderd als gevolg van de beslissing van het kabinet Lubbers om niet langer standaardregelingen van welke ard ook te sanctioneren, ook al zijn deze in naw overleg met de overheid tot stand gekomen. Een zuiver politieke beslissing dus.

Over het koncept-" 85 bestond bovendien onder de BNA-leden grote ontevredenheid: door de jarenlange onderhandelingen was de duidelijkheid er niet op vooruit gegan en waren de matschappelijke veranderingen in de architektenpositie er niet in terug te vinden.

Het BNA-bestuur besloot daarop tot het instellen van een werkgroep samengesteld uit leden met de nodige praktijkervaring in de verschillende onderdelen van het vakgebied.

Deze werkgroep heeft tussen medio 1986 en medio 1987 het Derde Koncept-'85 geheel herschreven. In april 1987 is dit werkstuk in principe goedgekeurd door de Ledenvergadering van de sektie Partikuliere Architekten. De eindredaktie is afgerond op 1 juni 1987, waarna een uiteindelijk fiat van Sektieledenvergadering is verkregen in september 1987 . In dezelfde ledenvergadering is besioten om voor nietoverheidsopdrachten de SR in te doen gaan op 1 oktober 1987 , voor overheidsopdrachten op 1 januari 1988. Zulks in verband met het heropende overleg met de "werkgroep Thunnissen II".

V.1.2.2

globale aanduiding van de belangrijkste ontwikkelingen in de $S R^{\prime} 87$ ten opzichte van AR'7I

Zoals ook bij vorige regelen het geval was, blijft deze standaardregeling bindend voor de leden van de BNA. Een dergelijke bindendverklaring is alleen mogelijk als de regeling, in het algemeen gesproken, voor alle voorkomende situaties bruikbaar is. De werkgroep heeft daarom een kader wilen aangeven, waarbij alleen de essentièle zaken zijn geregeld. Onderstaand wordt op enige daarvan ingegaan.

Algemene bepalingen (art. $1 \mathrm{t} / \mathrm{m} 12 \mathrm{SR}$ ) Het begrip architekt (art. I SR). Niet alleen de naturuijke persoon maar ook (semi) rechtspersonen worden als zodanig onschreven. 
kostenbegrippen (art. 2 sR). Veel diskussie is er altija geweest over de vraag wat onder de bouwkosten als honoreringsgrondslag moet worden verstaan (art. 9 lid 2 en 3 AR"71) thans wordt werwezen naar een normworschrift waarin o.a. de verschillen tussen bouw- en investeringskosten duidelijk zijn gedefinieerd.

- Agemene bepalingen omtrent de opdracht. Inhoud en totstandkoming van de opdracht. De architekt is thans te veel betrokken in komplexe situaties om een regeling ex. art. 3. $A R^{\prime} 71$ nog te kunnen handhaven. Een exacte omschrijuing van alle opdrachtsituaties is onmogelijk, daarom is volstaan met de verplichting tot het regelen van essentiêle elementen waruit de opdracht bestaat: de ard, de omvang, de bouwtijd, het budget voor het bouwplan, de wijze van honoreren.

Gezien de diskussie in het verleden of, en in hoeverre, er sprake was van een gegeven opdracht, is aanbod- en aanvarding darvan thans goed geregeld (art. 4 lid 1 SR).

- algemene verplichtingen van partijen (art. $5,6,7 \mathrm{SR}$ ) de architekt:

- de oude terminologie "goed en zorgvuldig" voor de vervulling van zijn opdracht is weer opgenomen, terwijl ook het vertrouwengbeginsel weer is teruggekeerd (in het Derde Koncept was dat begrip als "onzakelijk" geschrapt). De ard van de architektenopdracht bergt echter in $z i c h$ dat slechts zijn mate van inspanning als toetssteen voor zijn funktioneren kan worden gehanteerd, althans voor het grootste deel van zijn arbeid. Een dergelijke toets kan slechts gegrondvest zijn op vertrouwen.

Hij is verplicht om informatie te verstrekken aan zijn wederpartij omtrent te verwachten problemen en kosten bij de planontwikkeling, en, indien gewenst, over de wijze warop hij de opdracht denkt te gaan uitwoeren en wie hem daarin bijstaan.

De esthetische warde van het ontwerp is buiten diskussie. De poging uit het Derde Koncept om een toetsingsnorm te introduceren is gewogen en te licht bevonden.

De opdrachtgever:

- dient de verplichtingen van de architekt uit hoofde van zijn beroep te respekteren, dus ook zijn vertrouwenspositie te erkennen en daarnaar te handelen

- moet ontwerpgegevens tijdig terbeschikking stellen, en het door de architekt geproduceerde tijidig beoordelen

- ingrijpen in de totstandkoming van het ontwerp en of uitvoering daarvan buiten de architekt om is niet toegestaan

- de architekt is exkend als bevoega in-en extern vertegenwoordiger (art. 7 SR). Voor de uitvoeringsfase wordt een en ander meer expliciet geregeld lart. 21 lid 
1 sub a SR zie ook hoofdstuk V.2.4 en V.2.5

- vertegenwoordiging van de opdrachtgever - de architekt heeft voor een goed funktioneren een duldelijke tegenspeler nodig, met de nodige bevoegdheden. Daaraan blijkt het nogal eens te ontbreken.

- adviseurs, koörainatie etc. (art. $8 \mathrm{t} / \mathrm{m} 12 \mathrm{SR}$ ) opdrachten aan adviseurs.

De samenwerking met andere disciplines is pas dan optimall wanneer ook een daadwerkelijke synthese van de samensteliende gebouwonderdelen kan ontstaan. Het is daarom essentieel dat de architekt minstens bij de aanstelling wordt geraadpleegd. Ook is het mogelijk dat op voorstel van de architekt adviseurs worden benoemd als deze dat voor de vervulling van de opdrachten noodzakelijk acht. Bij de formulering van deze bepalingen is ervan uitgegaan dat de opdrachtgever aan alle disciplines de opdrachten verstrekt, en derhalve ook dient toe te zien op de nakoming ervan. Dit behelst de inhoudelijkheid en het tijastip warop het advies wordt gegeven.

bouwkundige inpassing (art. 9 SR) en projektkoördinatie (art. I0 SR)

Deze twee begrippen zijn duidelijk gescheiden. Het architektonisch ontwerp vereist een synthese van de adviezen van derden met de visie van de architekt. Deze is echter niet verantwoordelijk voor het tijd/kostenelement van deze adviezen. Daartoe kan wel een aanullende opdracht worden verstrekt.

bouwteam (art. $11 \mathrm{SR}$ )

vereist een duidelijke formulering van de werkzaameden en verantwoordelijkheden van de architekt, en van die van de overige disciplines, door de opdrachtgever.

algehele adviesopdracht (art. $12 \mathrm{SR}$ )

daarbij wordt de architekt de enige opdrachtnemer tegenover de apdrachtgever/principal. Stellig is dit de meest heldere kontraktsituatie die kan worden toegepast die overigens ad hoc moet worden geformuleerd. Er is éch verantwoordelijke voor het totalikoncept, ook inhoudelijk, en dat is de architekt. De wens om tot een dergelijke regeling te komem zagen wij reeds verwoord in de brief van de CHH an het BNA-besturur d.d. 21-07-1969. Het valt te verwachten dat de praktijk an dit artikel niet voldoende zal hebben.

Algemene bepalingen bij de opdracht voor een bouwprojekt (art. $13 t / m 15 \mathrm{SR}$ )

Definities:

- fasering (art. $14 \mathrm{SR}$ ) duidelijker juridische markering van de overgang naar een volgende fase. 
- vergunning/beschikkingen (art. $15 \mathrm{sR}$ )

de bepalingen van de gemeentelijke bouwvergunning behoren

tot het takenpakket van de architekt. Alle overige

vergunningen en ook de vertaling daarvan in het bouwplan moeten in onderling overleg worden geregeld, op initiatief van de opdrachtgever. De onstuimige groei van

overheldsbepalingen terzake van het bouwen, financiëren van projekten en de eisen die de overheid t.a.v.

produktieprocessen stelt, werhindert een ruimere taak van de architekt op dit terrein als kontraktueel onderdeel van zijn opdracht.

Dit houdt dus een beperking in t.o.v. art. 32 AR.

Omdat het gewenst is een scheidslijn aan te brengen tussen wat des opdrachtgevers taak is, en wat des architekts is voor deze duidelijkheid gekozen.

- fasen van de opdracht (art. $16 \mathrm{t} / \mathrm{m} 21 \mathrm{SR}$ )

beatedingsgereed maken is tot één onderdeel geworden dat de oude opdeling ex. art. 4 AR'7l in begroting, bestektekeningen en bestek omvat, onder de naam "voorbereliding van de uitvoering". Hierin is mede begrepen het werktekeningen bestanddeel nodig voor de start van de bouw na besteding.

Het begrip aanbesteding is verruimd. Ook als er niet besteed wordt zijn de bemoeienissen van de architekt hetzelfde, of zelfs meer.

Een duidelijk ondergcheid wordt gemakt tussen direktievoering en toezicht (art. 21 lid 2 en 3 SR)

N.B. Werktekeningen vormen géén apart onderdeel meer in de honorering. In het kader van de steeds verder gaande automatisering van de ontwerpwerkzaameden is een dergelijke scheiding niet verantwoord an te brengen.

- Elke fase bevat een toetsing van het budget. Bij de omschrijuing van het per fase te verrichten tekenwerk is aansluiting gezocht bij NEN 2574 .

- bevoegdheid van de architekt bij de direktievoering (art. 16 en $17 \mathrm{SR}$ )

opdragen van bestekswijzigingen beperkt tot 28 van de a anneemsom, besteden van stelposten (zie hoofdstuk V.2.4)

- toezicht

bevoegdheid van de architekt tot het aanstellen van een opzichter.

Andere werkzaamheden (art. 24 en 25 SR)

Opdracht tot het vercichten van een vóbronderzoek (art. 24 $S R$. Het vóbronderzoek heeft daarmee een duidelijke aparte status verkregen. De formulering van deze aparte opdracht wordt in onderling overleg bepald. Gezien de grote verschillen die zich in de praktijk voordoen, is een exacte omchrijuing niet te formuleren. De honorering geschiedt 
navenant al naar gelang de situatie.

- Een uitgebreide opsoming van datgene wat verder door de architekt nast de normale opdracht kan of moet worden vericht.

\section{Algemene financiële bepalingen: (art. $26 \mathrm{t} / \mathrm{m}$ 34 SR)}

De duidelijke scheiding heeft tot gevolg dat diskussies over wat wel of niet tot de feitelijke opdracht behoort, tot het verleden kunnen gaan behoren.

- wijze van honorering (art. 27 en 28 SR)

Er zijn drie methoden:

via het percentage, dus op grondslag van de bouwkosten

via bestede tijd

deze honoreringswijze kende in vroegere koncepten een "vloer": in elk geval niet lager dan het percentage. Die beperking is komen te vervallen. Dit impliceert dat in principe prijskonkurrentie tussen architekten de plats van kwaliteitskonkurrentie kan gaan innemen. Het zal derhalve voor de hand liggen dat de bij wijze van proef in Friesland reeds jaren funktionerende meldingsplicht, tot het gehele land zal moeten worden uitgebreid. Bij invoering wan een europese regeling ontstan op dit punt ook international problemen.

via vast bedrag

wijze van deklareren (art. 29 e.v. SR)

de specifieke plicht van de architekt is nieuw, alsmede de mogelijkheid van accountants-kontrole

- Honorering op grondslag van de bouwkosten, bestede tijd, en vast bedrag (art. $35 \mathrm{t} / \mathrm{m} 48$ SR) wijze van bepaling honorarium (art. $35 \mathrm{sR}$ ) samenloop van verschillende klassen, verbouwingstoeslag (30s als vroeger, tenzij darin qua klassering is voorzien)

Indeling in zes klassen. Vooral de komplexiteit van de woningbouw noopte tot differentiatie. In de bijlage bij de $S R$ worden voorbeelden van klasse- indeling gegeven.

NEN 2631 als honorarium grondslag, $1 / 5$ aftrek bij onafhankelijk advies inzake samenstellende delen van het ontwerp door andere disciplines (art. 37 SR).

Eén formule voor de b-bepaling voor alle klassen: honorarium verdeling over de fasen. Het hoofdaccent ligt bij de ontwerpfase (308) en bij de voorbereiding van de uitvoering (40\%). Deze opbouw i gekozen met het oog op het geautomatiseerd ontwerpen warbij de gegevensverwerking voornamelijk platsvindt in de fase van definitief ontwerp en bouwvoorbereiding (art. 38 en 39 $S R$ ).

Konsekwenties van wijzigingen en varianten in het ontwerp of de goedgekeurde fasen strakker omschreven (art. $40 \mathrm{SR}$ ). 
Herhaling van het bouwprojekt - er is een basisvergoeding van 15 van het totale honorarium ingevoerd voor het auteurstecht. Wijzigingen en anpassingen worden apart gehonoreerd.

N. B. het goedkeuringsvereiste van de apdrachtgever voor herhaling voor andere opdrachtgevers is vervalien.

Toeslag van 30 op het honorarium voor samenwerking ad hoc van twee architekten op verzoek van de opdrachtgever, zoals ook in de $\mathrm{AR}^{\prime 71 / 83}$ was voorzien.

Bij hantering van de vast-bedrag methode lart. 47 en 48 SR) dient dit bedrag per fase te worden overeengekomen. Daarmee wordt bereikt dat de financielle risiko's van de architekt overzienbaar blijuen. In deze honoreringsmethode is de "vloer" van de percentageregeling blijven staan, ter vermijding van al te grote risiko's voor de architekt.

Vergoeding van kosten en verschotten (art. $49 \mathrm{t} / \mathrm{m} 52 \mathrm{sR}$ ) Geen bijzondere wijzigingen.

Aansprakelijkheid van de architekt (art. $53 \mathrm{t} / \mathrm{m} 60 \mathrm{SR}$ )

- Aansprakelijkheid van de architekt bij bevoegdheidsoverschrijding tijdens uitvoering. De vermogensschade die daarbij kan optreden kan niet via verzekering worden gedekt. Datzelfde geldt voor vertragingsschade als gevolg van te-lat-presteren van de architekt (tekeningen te lat at.

Een beperking is ingevoerd voor de aansprakelijkheid wan schade tot het herstel van gebreken als rechtstreeks gevolg van verwijtbare fouten. Het subsidiariteits beginsel blijft gehandhaafd (primaire ansprakelijkheid voor a mnemer, leverancier en derden).

Overschrijding bouwsomlimiet - de grens wordt van 20 o (art. 30 lid 2 AR) op "ten naste bij" wastgesteld. Gezien de marktiluktuaties bij bestedingen is een vast, lager, percentage njet vast te stellen (art. 3 lid 3 sub a SR).

Omvang van de schadevergoedingen,

bij onvolledige opdrachten:

niet hoger dan de helft van het honorarium met een maximum van $f 250.000 \ldots$

bij volledige opdrachten:

niet hoger dan $f$ 500.000,- of indien het hanorarium hoger is, niet hoger dan het volledige honorarium met een maximum van $f$ 1.500.000,Voor alle overige schaden geldt een beperking tot de helft van het honorarium (art. 57 lid 3 SR). 
Aansprakelijkheidstermijn: 5 jaar na uitvoering van de opdracht (art. 58 SR).

N.B. Er is een analogie gehanteerd met de koncept-Rvor, omdat er een steeds verdergaande verstrengeling optreedt tussen de ontwerpende disciplines. (zie ook art. $12 \mathrm{SR})$. Daaruit zouden aansprakelijkheidsproblemen kunnen ontstaan. Er is ook doelbewust een scheiding gemakt in volledige en onvolledige opdrachten terzake van aansprakelijkheid ondat de risiko's anders liggen.

De ook thans nog doorgevoerde ansprakelijkheldsbeperkingen zijn een voorwarde gebleken voor de verzekerbarheid van de risiko's.

Bijzonder verloop en voortijdige beëindiging van opdracht (art. $61 \mathrm{t} / \mathrm{m} 7 \mathrm{IR}$ )

Nieuw is de mogelijkheid van beëindiging op grond van het ontbreken van de vertrouwensrelatie van elk der beide partijen.

- Uitgangspunt is dat bij vóortijalge beëindiging anders dan door wanprestatie of laakbare handelingen, de architekt $\mathrm{zijn}$ kosten krijgt vergoed. Is er sprake van wanprestatie van de architekt dan worden bij beëindiging op basis van prix $\mathbb{f}_{\mathrm{ixe}}$ of bestede tijd de kosten van de architekt vergoed tot $85 \%$. Bij wanprestatie van de opdrachtgever tot 115\%. Daarmee wordt tegemoet gekomen in de onkosten die door de benadeelle partij reeds zijun gemakt op het moment van beëindiging. Op dit ogenblik (mei 1987) zijn deze bepalingen in het koncept ter diskussie. Overwogen worat om het honorarium in elk geval te beperken tot het voorlopig ontwerp bij nietuitvoerbaarheid van de plannen terwijl te laat-presteren een schadevergoedingsplicht zal opleveren tot maximal de thelft van het honorarium.

Eigendomsrechten en auteursrecht van de architekt (art. 72 $t / m 79$ SR

De auteursrechtelijke bepalingen zijn wat duidelijker opgenomen, vooral het punt "wijzigingen" (art. 76 SR) omdat in de praktijk hierujt nogal wat problemen ontstonden ( $i n$ relatie met art. 25 lid 1 sub c). Een auteursrecht vergoeding wordt vastgesteld op 15 van het totale honorarium bij vóórtijaige beëindiging van de opdracht, dus bij uitvoering zonder betrokkenheid van de architekt. Deze $15 \%$ is ook gehanteerd in art. $35 \mathrm{SR}$.

Bewaarplicht van de architekt

Nieuw is de bewarplicht van de gegevens wan de opdracht gedurende 10 jaar, tenzij overdracht van deze stukken plaatsvindt aan de opdrachtgever of diens rechtsopvolgers.

Geschilden 
Het arbitral beding blijft van kracht. De mogelijkheid van een keuze tussen arbitrage of gewone rechter is afgewezen. voor het overige zif verwezen naar hoofdstuk V.6.

$V .1 .2 .3$

SR'87 - een nuwe koers?

Het vaagteken 3 tat er niet voor niets? De teneur van dit onderzoek ilist op een divergentile tussen matschappelijke en juridische ontwikkelingen op het stuk van het

architektenkontrakt. Daarom kan er beter gesproken worden van een inthalmanoeuvre van de regelgeving. De nieuwe koers woxdt maatschappelijk bepaald en het juridisch aspekt volgt aarzelend. In de $S R^{\prime} B 7$ zijn weer terug te vinden de a anbevelingen die de Commisie tot Herziening van de Honorariumregeling in 1967 deed.

De anpassing van de rechtsverhouding opdrachtgeverarchitekt an de trendmatige matschappelijke verschijnselen heeft ook een negatilef effekt: de verbrokkeling van de architektentaak wordt juridisch mogelijk gemaakt. Op zichzelf is dat geen goede ontwikkeling, het doet afbreuk aan het funktioneren van hem die juist het gebouw tot een synthese moet maken van vorm, funktie, techniek en kosten. De verbrokkeling doet onrecht aan bijna al deze facetten.

Juridisch ontstaan er kungtmatige grenzen die op het eerste gezicht helder en scherp lijken, maar dat in de dagelijkse praktijkt van het beroep niet zijn. Men vergelijke de betogen van mx. M.A.M. van den Berg (BR 72-p...) en van mr. van schravendijk (BR 86-p...) over kontrakten voor bouwen ontwerpteams.

De nieuwe rechtsverhouding stelt, de totaalopdracht primair, en dat is juist: de synthese blijft de meest ideale grondslag voor de architektonische conceptie. De hoop is gerechtvardigd dat de scherper geformuleerde verplichtingen van de architekt zullen dwingen tot meer "matschappelijke" kwaliteit.

$\forall .2$

De belangrijkste juridische diskussiepunten

$\mathrm{V} \cdot 2 \cdot \mathbb{1}$

de vertegenwoordiglngsbevoegdheid van de architekt

V.2.1.1

a lgemeen

Art. 1 van AR'71/'83 vermeldt nog dat de architekt in $z i j n$ algemeenheid optreedt als "gemachtigde" van de opdrachtgever, tenzij anders overeengekomen, dit in nawolging van $A R \cdot 32$ e.v. De SR:87 regelt algemene bevoegdheid tot vertegenwoordiging in art. 7 "de architekt is volledig bevoegd de opdrachtgever bij vervulling van de opdracht te vertegenwoordigen: tenzij partijen anders overeenkomen". 
Ten aanzien van het juridisch begrip "vertegenwoordiging" en haar gevolgen, bestat geen eenstemigheid. War Bloembergen ( *) het verrichten van rechtshandelingen namens anderen daarin begrepen ziet, breidt Van der Grinten ( 5 ) dit uit met feitelijke handelingen namens anderen. Het BW geeft daaromtrent geen uitsluitsel. Het NBW is daromtrent duidelijker: art. 6.3.2.4 NBW spreekt van "l gedraging" van de vertegenwoordiger en loopt dus parallel an de isie van van der Grinten.

De vertegenwoordiging wordt bowendien bepald door twee verschillende beginselen $t$. w. het autonomiebegirsel welke stelt dat voor iedere vertegenwoordigingshandeling een wilsuiting van de opdrachtgever is vereist en het vertrouwensbeginsel, warbij derden niet afhankeligk gesteld kunnen worden van hetgeen tussen twee anderen ten anzien van de bevoegdheid jegens hen, al of niet is bepald (het opgewekt vertrouwen).

voots speelt in de standarardoveenkomst opdrachtgewerarchitekt nog een rol dat soms over machtiging (art. $\mathbb{1}$ $A R^{\prime} 71$ ) soms over bevoegdheid tot vertegenwoordiging (art. 7 $S \mathbb{R}^{\prime} 87$ ), worat gesproken. Het zou kunnen zijn dat machtigen een aktie van de wederpartij impliceert wardoor dit in het verlengde komt te liggen van de lastgeving ex. $1829 \mathrm{Bm}$, en dat bevoegdheid tot vertegenwoordiging niet expliciet overeengekomen behoeft te worden.

Het gat dus steeds om de vraag of de overeengekomen bevoegdheid in geschilien daaromtrent wordt erkend. Adriaansens onderscheidt een nuanceverschil met betrekking tot optreden van de architekt vớr en na aanbesteding (* 6 ). van wijngaarden (* 7 ) onderscheidt ook de anbestedingsfase. Wet 1 igt dus voor de hand de arie trajekten van het bouwpraces op het punt van de vertegenwoordigingsbevoegdheid van de architekt te bezien.

v. $2 \cdot 1 \cdot 2$

bij de planontwikkeling tot aanbesteding

- Vooronderzoek (art. 24 SR'B7). Bestond nog niet in de $\mathbb{R}^{\prime}$ 71. De omvang van de opdracht hiertoe is per definitie beperkt. De jurisprudentie zal moeten uitwijzen of de architekt als vertegenwoordiger zal worden beschouwd of niet. Is het eerste het geval, en dat ligt in rede, immerg ook op dit onderdeel is de SR integraal van kracht, dan kan er sprake zijn van bevoegdheid tot vertegenwoordiging krachtens jurisprudentie, o.a.:

Rb Groningen 4-4-1975 BR 1975 blz. 627, hoewel een ander arrest het tegendeel atelt inzake een verrichte grondboring ( $R b$ Den Bosch 4-11-49 NJ 1950/563).

- Voorlopig ontwerp - hetzelfde geldt hier als bovenstand. van wijngaarden konkludeert dat er geen sprake is van bevoegdheld op grond van de omschrijuing van de werkzaamheden in $A R^{\prime} 71 /{ }^{\prime} B 3$ art. 4 sub a jo. ontwerp $S R^{\prime \prime} 85$ art. 11. Het is echter zeer wel mogelijk dat ook in deze 
fase adviezen van derden, en dus kontraktuele bindingen, noodzakelijk zijn, met daarmee verbonden een al of niet overeengekomen vertegenwoordiglingsbevoegdheid.

- Definitief ontwerp - als boven. In tegensteling tot het door Van Wijngaarden (* 8) veronderstelde is er echter bij het definitief ontwerp meestal nog geen sprake van onderhandelingen met overheden e.d. Hoogstens owerleg met de welstand.

- Voorbeceiding van de uitvoering - in deze fase van de opdracht $z i j n$ besprekingen $c . a$. onderhandelingen met de overheid en eventueel derden noodzakelijk. Bij de taakomschrijuing ex. art. 19 SR'87 is expliciet het aanvragen van de Gemeentelijke Bouwvergunning genoemd en het voeren van de daartoe vereiste besprekingen. Dat legitimeert de architekt als vertegenwoordigingsbevoegd. Ten aanzien van de overige vergunningen is gesteld in art. 15 SR "B7 dat ower de akties in dit verband afspraken moeten worden gemaakt tussen opdrachtgever en architekt. Het is derhalve niet wargchijniljk dat daruit nog bevoegaheidsvragen naar voren zullen komen. overigens werd ook in de vroegere situatie de architekt zonder expliciete-opdracht bevoegd geacht om namens de opdrachtgever op te treden (Rb Den Bosch 10-07-68 BR 1968 blz. 419 - Hof Amsterdam 29-03-1966 - HR 33-67 NJ 1967/193)

V.2.1.3

bij a anbesteding

- In het Uniform Aanbestedings Reglement (UAR) 1986 wordt steeds "de aanbesteder" genoemd war vroeger sprake was van "de opdrachtgever". In het UAR 1986 wordt met aanbesteder bedoeld "hij die voornemens is een werk op te dragen". In de SR'87 is bij de opsomming elk vertegenwoordigend optreden voorbehouden aan de architekt, ook bij gunning zonder aanbesteding.

Het lijkt dat bevoegaheidsuragen, zo zijal gesteld worden, hier niet moeilujk te beantwoorden zijn. of dat in praktijk ook zo zal zijn, zal de toekomst moeten leren.

Van Wijngaarden en ook Adriaansens duiden erop dat door middel van het geven van inlichtingen en aanijzingen een beinvloeding van de a aneemsom door de architekt mogelijk is. Het UAR 1986 spreekt in deze van aanwijzing door of namens de opdrachtgever (art. 9) als ook ten aanzien van vergtrekte inlichtingen. De jurisprudentie leert dat de aanbesteder gebonden is a an de verstrekte inlichtingen. (RVA jan. 1925 nr. 412, AR 1121928 , alsmede RVA $1954 \mathrm{nr} .2102$ ). Daarentegen zijn foutieve aanwijzingen bij de bestedingen, door de architekt gedaan ten laste van de opdrachtgever vaak niet erkend.

ook vór de gunning tussen architekt en aannemer overeengekomen bezuinigingen zijn bindend voor de opdrachtgever (RVA $1940 \mathrm{nr}$. 1212 zie verder Van hijngaarden Bouwrecht 7 bliz. 26 e.v.). Bevoegdheidsvragen zullen $z i c h$ 
De gunning wan het werk makte geen deel uit van de architektenopdracht ex. SR'87. Toch zal de bevoegdheid daartoe doorgaans worden aangenomen op grond wan het vertrouwensprincipe. De jurisprudentie verloopt ook als zodanig. Zie Van Wijngaarden hoofdstukken Bouwrecht nr. 7 blz. 29 .

V.2.1.4

bij de uitvoering - direktievoering door de architekt

In de SR'87 wordt onder art. 21 lid la de taak van de architekt omschreven als "het vertegenwoordigen van de opdrachtgever in alle zaken de uitvoering betreffende". Daarin verschilt de omschrijving van de vertegenwoordigingsbevoegdheid niet van alle voorgaande Algemene Regelen vanaf 1922. Echter thans met twee voorwarden:

- tenzij partijen anders overeenkomen

- voorzover de tussen opdrachtgever en annemer gesloten aannemingsovereenkomst $z i c h$ daartegen niet verzet.

De eerste voorwarde is ingevoerd vanwege de opdrachten warbij delen van de direktievoering worden voorbehouden aan de opdrachtgever of derden. De tweede voorwarde is ingevoerd met het oog op uitsluitingen van de bevoegdheld van de direktie krachtens de UAV. Niet altija zal de UAV echter van kracht zijn.

Wanneer de architekt belast is met de dicektievoefing is zijn positie als vertegenwoordiger van de opdrachtgever zeer sterk. Tegenover de aannemer zal al gauw sprake zijn van een opgewekte schijn van bevoegaheid, zelfs al is die feitelijk niet aanwezig. De jurisprudentie stelt de aannemer vrijwel altijd in het gelijk, (zie hiervoor Van wijngaarden hoofdstukken Bouwrecht nr. 7 blz. 44 e.v.) alsmede Adriaansens POG II G-88). Zie ook HR $1.3 .68 \mathrm{NJ} 1968 / 246 \mathrm{BR}$ 1968 blz. 245).

Men zou theoretisch nog een onderscheld kunnen maken in vertegenwoordigingsbevoegdheid van de architekt bij uitvoering in financiële zin (geen bevoegaheid gezien de terzake geldende uitsluituingen in de UAV) en in technische zin (well bevoegdheid $0.9 \cdot v . A R / S R$ ). Van wijngaarden duidt erop dat middels technische ingrepen altija financièle gevolgen ontstaan als neveneffekt en dat dus het een het ander impliceert.

Toch heeft de RVA in deze gevalien de vroegere gerechtelijke beslissingen gevolgd (RVA 17.7 .73 nr. 6903 BR $1973 / 631$ en RVA 29.11 .73 no. 6514 BR 1974/128).

Bij lichtvararg of te kwader trouw handelen van de architekt of bij door hem gemakte fouten, is de opdrachtgever overigens niet altijd aan diens beglissingen gebonden (BR $1975 / 589$ en BR 1975/117). 
Externe onbevaegde vertegenwoordiging door de architekt tegenover de annemer wordt niet snel geaccepteerd. Wel kan zulks leiden tot a ansprakelijkstelling van de architekt voor de gevolgen. Expliciet geldt zulks ten aanzien van overschrijdingen van het afgesproken meerwerkbedrag, posten onvoorzien of atelposten, tenzij een en ander als spoedelsende voorziening noodzakelijk is (art. 71 AR'71, ook in $\mathrm{AR}^{\prime} 56$ en ${ }^{\prime} 64$ ). In de $5 \mathrm{R}^{\prime} 87$ is zulks verderstrekkend dan voorheen: art. 54 stelt de architekt niet alleen a ansprakelljk voor de overschrijding maar voor de overige shade die door de opdrachtgever als gevolg van de overschrijaing wordt geleden. Voor deze schade gelden andere Iimieten 1 s genoemd in art. 57 SR'87. Zodanig gevolg van onbevoegd handelen van de architekt wordt ook uitgesloten in de meeste polissen van beroepsansprakelijkheid. overschrijdingen wan de bevoegaheid maken de architekt a ansprakelijk voor maximaal de helft van $z i j n$ honorarium.

De vertegenwoordigingsbevoegaheid van de architekt in gevallen warin geen sprake is van een primaire relatie met de opdrachtgever, b.v. wanneer een aannemer en een architekt samen een plan koncipiëren, en na gunning wordt de architekt dicektievoerder, is steeds aiskutabel. Er komen vormen voor warin architekt en annemer in Eeite éen partij vormen tegenover de oparachtgever. In zulke gevalien pleegt de vertegenwoordigingsbevoegdheid van de "architekt" steeds te worden ontkend (RVA 1.5 .62 no. 3607 ).

Tegenover derden, niet bij de bouw betrokken, is na de uitsprak van de HR inzake Vaz Dias/Salters (HR 6.5.26 NJ 1926 - 721) duidelijk dat de vertegenwoordigingsbevoegdheid van de architekt in deze zin beperkingen kent. Het opgewekte vertrouwen van de wederpartij wordt daarin gekoppeld aan de vertegenwoordigde partij en niet aan de vertegenwoordigende. Niet allen achten dit juist, immers, hoe kun je gehouden zijn aan vertrouwen dat je niet gegeven hebt (zie Meijers noot bif HR 18.6.26 NJ $1926-1021$ ).

Van Wijgarden gat nog in op de vertegenwoordigingsbevoegdheid van de architekt ten aazien van bestellingen yoor aannemers en opdrachtgevers bij leverancilers (BR 1976 blz. 109). Ook in de dertiger jaren kwamen geschillen omtrent de verplichtingen uit dien hoofde nogal eens voor (zie toofdstuk III), hetgeen voortvloeide uit de niet altijd onathankelijke positie van de architekt. Hoewel daarover in 1960 mog en vonnis werd gewezen (Rb Arnhem $24.3 .60 \mathrm{Nj} 1960$ - 482) mag worden a ngenomen dat zulks thans niet meer voorkomt.

V.2.1.5

bij de eindafrekening

In de standaaravoorwarden is bepald dat de architekt de eindafrekeningsbescheiden opmakt en an de opdrachtgever voorlegt ter filatering. Is de opdrachtgever gebonden als 
die bescheiden direkt aan de a annemer worden angeboden, en door deze en de architekt worden geaccordeerd?

Van wijngaarden beantwoordt die vraag in beginsel

bevestigend (zie hoofdstukken Bouwrecht 7 blz. 97). De UAV sluit die bevoegdheid evenmin uit, de arbitrale

jurisprudentie bevestigt dit (RVA $1951 \mathrm{nr} .1633$ ).

V. 2.2

De honorering van de architekt valgens de $A R^{\prime} 71 /{ }^{\prime} 3$

De grondslag wordt gevormd door de bouwkosten warvan de definitie wordt gegeven in art. 9. Een diskutabel punt daarbij wordt gevormd door art. 9 lid 2 sub e "de kosten ven normale technische installaties voor verwarming,

luchtbehandeling, verlichting, gas-en elektriciteits-en watervoorziening etc. " etc." Vooral bij de snelle

technische ontwikkeling van geavanceerde kilmat-

installaties in de zestiger jaren, is over het begrip

"normaal" nogal eens gediskussieerd. Zie ook Adriaansens -

Praktijkboek Onroerend Goed II G 44 .

In de SR" 87 wordt voor het begrip bouwkosten en wat daaronder dient te worden begrepen verwezen nar het normblad NEN 2631 "investeringskosten van gebouwen".

Een oorzaak van geschillen waren vak de extra toeslagen op het honorarium voor bijzondere omstandigheden. Vooral art. 14: 308 extra voor verbouwingen, herstellingen en uitbreidingen, mits hierdoor de tak wan de architekt wordt verzward. Deze laatste voorwaarde is essentieel: AIB 11-878 BR $1973 / 562$ en AIB $13-8-75$ BR $1976 / 186$. De toeslag gaat ervan uit dat door deze komplikatie een vermeerdering van het aantal door de architekt te besteden uren voortvloeit. hetgeen veelal ook zo is.

voorts: art. 15 lid 2, kent een extra toeslag van $20 \%$ toe aan de architekt die in de planfase aan zijn teken- en vergadertafel, "reeds lang voor de aanvang van de uitvoering", de aannemer ontmoet. Sommigen leiden hieruit een poging af om de planfase voor de architekt te reserveren en de formatie van het bouwteam met de a annemer tegen te gaan. Het is echter heel goed denkbar dat de toeslagregeling is geboren uit dezelfde overweging als die van de verbouwings-toeslag: doorgaans zal een bouwteam worden gevorma wanneer zich specifleke technische problemen kunnen voordoen warvoor de pecifieke materieelpositie van de aannemer essentieel is. Op zichzelf kan dit takkerzwarend werken voor de ontwerper. De vrees hiervoor is echter valk ongegrond gebleken en naarmate het verschijnsel bouwteam meer inburgerde is het effekt van de toeslagregeling meer en meer verloren gegaan.

In de $S R^{\prime} 87$ is aan samenwerkingswerbanden in meerdere vormen aandacht besteed (art. I 1 en 12 SR'87). Het streven is daarbij om, war vele samenwerkingsvormen in de praktijk zich voordoen, de overeenkomst

opdrachtgever-architekt zuiver te houden en te dwingen tot een duidelijke afbakening van taken en 
verantwoordelijkheden. Er wordt daarbij onderscheid gemaat in projektbegeleiding in financielle $z i n$ voor alle disciplines, of alleen voor het bouwkundig deel. Het latste is inbegrepen in het honotarium volgens de formule van art. $35 \mathrm{SR}^{\prime} 87$, al het overige moet apart worden overeengekomen en gehonoreerd.

Art. 15 1id 3. Verdubbeling van de percentages ex. art. 7 voor a anbesteding direktievoering en eindoplevering (de facto $27,5 \%$ extra) voor werk in regie uitgevoerd. Dit is een ongelukkige regeling. In feite wordt niet echt aanbesteed en uitgegaan van een budget. De architektentaak wordt bij regiewerk aanzlenlijk verzward doch het is julster daarvoor een honorariumregeling te treffen volgens de bijlagen IV en $\checkmark$ naar bestede tijd, na vaststeling van een daartoe strekkend budget.

In de SR"87 komt een dergelijke regeling niet meer voor. Dit type opdrachten kan worden afgerekend naar bestede t迎d.

Art. 16. 308 toeslag voor samenwerking op verzoek van de opdrachtgever van twee niet in een matschap verbonden architekten. Deze regel is gebaseerd op de vrijwildige keuze van de opdrachtgever voor twee architekten i.p.v. éen. Het is juist de daaraan verbonden extra arbeid met $30 \%$ te honoreren, het gat hier immers om het verlangen naar of een grotere zekerheid bij een eventueel wegvallen van de eigenlijke architekt, of een verwachting van hogere kwaliteit vanwege een inbreng van de tweede architekt. In beide gevallen is een daadwerkelijke inbreng van de tweede architekt noodzakelijk, welke hiermede wordt gehonoreerd.

Art. 7 lid 3 jo, art. 5 lid 3. 5 toeslag op het honorarium voor ontwerp tot en met aanbesteding wanneer aan de oorspronkelijke architekt de direktievoering en eindoplevering niet wordt opgedragen. Daarboven ontstat een voor de opdrachtgever verplichte adviesbevoegdheid van de architekt, welke separaat moet worden gehonoreerd tot een maximum van $15 \%$ van het totale honorarium.

Het is niet duidelijk warom thet resterende architektenwerk (art. 4 sub a $t / m$ f) wordt verzward vanwege het niet voeren van direktie en het niet verzorgen van de eindoplevering. Natuurlijk dient de architekt in het onderhavige geval steeds toegang tot het werk te hebben om te kunnen adviseren bij afwijkingen van het ontwerp, doch het was beter geweest deze bevoegdheid te ontlenen aan de bepalingen van het Auteursrecht en het derhalve op te nemen onder het hoofd "Eligendoms- en Auteursirechten".

In de SR'B7 is deze bepaling vervalien. Bij de grote diversifikatie van kontraktvormen moeten opdrachtgever en architekt zelf de invulling verzorgen. Het koncept geeft daarvoor voldoende richtlijnen en kaders. 
Bij de honorariumregeling uit de $A R^{\prime 71 /} 83$ ligt, rellatief gezien, het zwartepunt van de financielle verplichting van de opdrachtgever in de eerste planfase van het ontwerp. 358 van thet totale honorarium is verschuldigd na het definitief schetsontwerp. Onlogisch is dat niet: de architekt deklareert achteraf (art. 24) en moet derhalve zijn werkzamheden en die van zijn medewerkers vóctinanciëren. Daarnaast wordt wel gesteld dat een hoge financielle "arempel" de architekt zou behoeden voor al te lichtvaraig verstrekte opdrachten.

Dit argument stat echter op gespannen voet met de vele procedures die desondanks zijn gevoerd over de vraag of er nu wel of geen opdracht was verstrekt aan de architekt.

Naast het honorarium brengt de overeenkonst architektopdrachtgever nog andere kosten met zich mee, te weten:

a. verschotten

b. werktekeningen, indien verlangd

c. taezicht

a. De verschotten (verrekenbare onkosten) bestaande uit reis-, verblijf-en reproduktiekosten. Vooral deze laatste post kan behoorlijk uit de hand lopen, ondanks het feit dat daarvoor veellal tevoren een budget wordt overeengekomen.

Vooral grote projekten kennen steeds meer aan het ontwerpproces deelnemende partijen die zich met elkar via tekeningen verstaan. De architekt koördineert deze gegevensstromen en bundelt ze in de plannen. Het is vaak moeilijk tevoren in te schatten hoe omvangrijk deze informatieuitwisseling zal gaan worden.

Een tweede moeilijk inschatbare grootheid is het aantal tekeningen dat voor de te verkrijgen goedkeuringen noodzakelijk 1 s. Met de toename van de overheidsbemoeienis wa de regelgeving en goedkeuringverlenende instanties, neemt de behoefte aan gegevensverstrekking via tekeningen exponentieel toe.

In het kader wan de wens tot kostenbeheersing in het ontwerpproces komt het thans voor dat, ook bij opdrachten in de seer van de semi-overheid, een verschotenbudget dwingend an de architekt wordt opgelegd via een clausule in de opdracht. Daarmee wordt het overschrijaingsuisiko van de opdrachtgever nar de architekt verschoven, zonder dat de latste in stat is dit risiko redelijkerwijs te kwantificeren.

Het is echter niet aanvardbar een kontraktpartij en niet kwantificeerbaar risiko af te dwingen.

b. Werktekeningen. In de $A R^{\prime} 71 / 483$ wordt niet duidelijk omschreven war de scheiding ligt van de tekeningen welke onder het honorarium vallen en welke voor nadere verrekening in aammerking komen. 
Art. 4 sub $C A R^{\prime} 71 / 83$ noent, onder verwijzing naar sub 9 "het maken van die werktekeningen welke voor de"

a anbesteding nodig zijn". Deze liggen dus in de nietvercekenbare feet, en art. 4 gub $g$ AR'71/"B3 spreekt van "de overige werktekeningen ten behoeve van de uitvoering" de wel verekenbar zijn via art. 8.

De meningsverschillen die uit deze onduidelijkheid voortuloeien zijn talrijk. De financiele konsekwenties van dit deel van het architektenwerk $z$ ijn aanzienlijk wanneer de verrekening niet plats vindt op basis van Bijlage IV (gemakte kosten). Dat is thans uit

budgettaire overwegingen nog slechts zelden het geval. Via het percentage in de tabellen belopen deze kosten 50\%-60* van het verschuldigde honorarium, dat daarboven nog moet worden uitgegeven.

Was in het nog niet zo verre verleden de verrekening tegen gemakte kosten nog vrij algemeen, even algemeen waren de geschilien over de hoogte van het verschuldigde bedrag ( 9). Dit heeft er toe geleid dat opdrachtgevers er oteeds vaker toe overgingen dit overschrijdingsrisiko van het budget te ontgaan door gebruik te maken van de percentageregeling in de tabelien.

In de $5 R ' B 7$ is de werktekeningenhonorering deels verdisconteerd in de "voorbereiding voor de uitvoering", deels in de "direktievoering" als onderdeel van het honorarium.

c. Kosten van toezicht. De tot betaling strekkende bepalingen in de $A R^{\prime} 7 l^{\prime} 83$ zijn duidelijk, bovendien worden afspraken daarover doorgaans in onderling overleg tussen partijen gemakt. Diskussie is nogal eens ontstaan vanuit de situatie dat, bij kleine werken, de architekt zèlf ook het toezicht verzorgt, dan wel dat de opdrachtgever de toezichthouder tevens een direktievoerende taak toedicht. (* 10).

Het samenlopen van niet verrekenbare direktievoering door de architekt en wel-verrekenbare kosten van toezicht vraagt on duidelijke afspraken.

V.2.3

Wanprestatie

De bouwsomliniet ex art. 31 Iid 2 AR"71.

De meeste gevallen van wanprestatie van de architekt, althans warover zich jurisprudentie heeft ontwikkeld, handelen over de overschrijding van de bouwsomilmiet, derhalve wanneer bij aanbesteding blijkt dat het overeengekomen bouwbudget in aanzienlijke mate is overschreden. Primair geldt dienaangaande dat opdrachtgever en architekt daarover duidelijke afspraken moeten hebben gemakt (art. 31 lid 1 jo 1 id $2 A^{\prime} 71 / 33$ ). Art. 31 lid 2 stelt de maximale limiet voor een overschrijding van de 
overeengekomen bouwsom op 208. Wanneer verwezenlijking van het werk een bedrag zou vergen dat deze limiet overschrijdt, is de architekt gehouden thet ontwerp aan te passen zonder honorarium. Als voorwarde gelat dat deze overschrijaing dan niet het gevolg mag zijn van omstandigheden die de architekt redelijkerwijs niet zijn toe te rekenen en dat tevoren een bouwsom is overeengekomen. Ben belangrijk gegeven hierin is de a anwezigheid van een bouwprogramma, immers slechts daarop kan de architekt enigszins beoordelen of het ontwerp voor de beschikbare som kan worden gerealilseerd. De praktijk leert dat veel opdrachtgevers hun bouwprogramma's eerst formuleren als de eerste (en latere) schetsplannen op tafel

verschijnen. De architektenovereenkomst behoort dan echter allang tot stand gekomen te zijn.

Ook van BNA-zijde is vaak kritisch angekeken tegen de marge van 20\%. Voor de zuiverheid van de verhoudingen zou een kleinere marge wenselijk zijn. Het probleem daarbij is dat het "marktmechanisme" bij de opdrachtaanvaarding moeilijk is in te schatten, zeker waar het openbare of onderhandse besteding-met-meerdere deelnemers betreft. De gekalkuleerde winst- en risikopercentages worden in tijden van hoogkonjunktuur nogal eens overschreden, al of niet tengevolge van opzetregelingen. In de neergang van de konjunktuur doen zich evenzeer verrassingen voor in omgekeerde $z i n$. Vooral waar veel bouwplannen reeds vóórgeprogrammeerd zijn op te verwachte goedkeuringen $t . a . v$. het budget, kan een onderschrijding van dit bedrag evenzeer leiden tot wanprestatie. Daar zal vooral sprake van zijn waar de feitelijke opdrachtgever afhankelijk is van financiële steun van de overheid.

Ten aanzien van het begrip winst risiko en algemene kosten zijn afwijkingen naar boven of beneden van loo geen uitzondering. Daardoor wordt de feitelijke marge voor wat betreft de architektenprestatie in de financiële sfeer reeds teruggebracht tot ca. 108 .

overachrijding van de 20 dimiet dwingt de architekt tot het terugbrengen van de bouwsom binnen de limiet zonder daarvoor honorarium te ontvangen. Lukt dat hem niet, dan verbeurt hij het honorarium voor het bestedingsgereed maken van het ontwerp met inachtname van de bekende voorwarde. Dat houdt in dat het honorarium over voorlopig en definitief ontwerp wel verschuläiga is. Dit vloeit voort uit de gedachte dat, alvorens een nieuwe planfase wordt ingegaan, de opdrachtgever al of niet stilzwijgend met het darin gepresteerde 15 akkoord gegaan. Niet duidelijk is echter warom, wanneer een bouwsom is overeengekomen en er bij toetsing van het voorlopig ontwerp (ex art. 4 lid a AR'32 t/m "71) financieel schijnbaar nog niets loos scheen, reeds toen geen sprake was van wanprestatie. Immers óf het ontwerp of de globale begroting klopte niet met de opdracht.

In de $S R^{\prime} 87$ wordt partijen dwingend opgelegd om de bouwsom en verdere financiële konsekwenties van de 
overeenkonst tevoren duidelijk met elkar overeen te komen (art. 31 id 2 SR' 87 ). Minder duidelijk is de SR'B7 terzake van de bowssomlimiet-overschrijding. De 20 -grens is vervangen door "het bedrag aan bouwkosten, dat ten naaste bij met de uitvoering van het bouwprojekt gemoeid zal zijn". Er is narstig gezocht naar een scherpere afbakening, mar die ia, naar eerder werd gesteld, niet te formuleren (zie hoofdstuk V.2.2).

Juriprudentie:

CVG $19-4-69$ BR $1970 / 215$

Geen bouwsomlimiet overeengekomen, geen wanprestatie architekt.

AIB $15-6-1971$ BR $1971 / 593$

Bewijslast overeengekomen bouwsomilmiet ligt bij de opdrachtgever.

Hof Den Bosch 6-5-1971 nr. 192, BR 1971/669

Bouwsom overeengekomen? Bewijslast ligt bij de architekt ex art. 1902 BW. Billijkheidsbeslissing? Zie prof.

mr. C.A. Adriaansens in POG II G-64.

CVG 25-4-1969 n.. 153 .

Geen bouwsomlimiet overeengekomen, geen wanprestatie architekt.

CVG $9-1-1970$.

Bowsom wel besproken mar niet overeengekomen. Geen wanprestatie architekt.

Hof Arnhem 28-12-1976 BR $1977 / 473$

Aanname van aanwezigheid van een overeengekomen 1 imiet. Bewijslast van het tegendeel ligt bij de architekt.

A I B $28-7-1976$.

Bouwsomlimiet gesteld? Bewijslast bij opdrachtgever. Geen wanprestatie van de architekt bewezen.

AIB $\quad 6-7-1976$.

Bouwsomlimiet overeengekomen? Bewijslast bij opdrachtgever. Geen wanprestatie architekt.

CVG $9-7-1969$.

Bouwsomilmiet gesteld en niet gehald. Wanprestatie, verbeurte van honorarium voor bestedingsgereed maken doch niet van ontwerp en onkosten.

AIB $2-6-1981$ (BR $1982 / 348$ ).

Geen bouwsom overeengekomen. Architekt had echter bij voorlopig- en definitief ontwerp opdrachtgever moeten inlichten over de kosten. De vermelding van het bouwbedrag op de bouwvergunning wordt daartoe niet toereikend geacht. Wanprestatie van de architekt, verbeurte van honorarium voor bestek en bestektekeningen. 
AIB $10-6-1981$ (BR $1982 / 346$ ).

Bouwsomlimiet overeengekomen. Overschrijding niet terug te brengen tot 20\%. Wanprestatie. Verbeurte van honorarium voor bestek en bestektekeningen.

$A I B$ 9-B-1983 (BR 1984/444).

Geen bouwsomlimiet overeengekomen. Geen wanprestatie architekt. Toewijzing honorarium.

AIB 28-5-1984 (BR 1984/743 met noot wesseling).

Uitdrukkelijk overeengekomen bouwsomlimiet. Afwijzing van het recht op honorarium, óok over voorlopig en definitief schetsontwerp. Dit laatste amdat de ontwerpen "niet van nut" $z i j n$ geweest ( $\mathrm{ex}$ art. 40 lid 2 , bij herroeping van de opdracht). Reconventionele vordering voor vertragingsschade afgewezen $0.9 \cdot v$. ontbreken van een grondslag dienaangaande in de AR"71.

Uit deze reeks van uitspraken komt duidelijk naar varen dat de belangen van de opdrachtgever in de tijd gezien steeds meer aandacht krijgen. Vooral de latste uitspraak, door Wesseling met instemming begroet, gat ver. Hoewel de details, belangrijk in dit soort zaken, in deze uitspraak onvoldoende naar voren komen, lijkt enige twijfel aan de juistheid ervan toch op $z$ 'n plats. Partijen waren de AR overeengekomen, zonder expliciete uitschakeling van art. 31 1id 2. Het absolute maximum is gekonstrueerd uit uitlatingen van de opdrachtgever. Interessant zou zijn om te vernemen of daarbij ook andere posten als verschotten e.d. inbegrepen moesten zijn. Wanneer, zoals in dit geval, ervan wordt uitgegaan dat er van meet af aan een onoverbrugbare kloof bestond tussen het budget en het plan, iets wat uiteindelijk tot verbeurte van het ontwerphonorarium leidde, dan kan het bevreemding wekken dat in het geheel niet gerefereerd wordt aan art. I AR'7l voor wat betreft de vertrouwenspositie van de architekt.

AIB 8-8-1984 (BR 1985/63 met noot wesseling).

Een derqelijk geval als het vorige. Thans echter worden de ontwerpkosten wel degelijk vergoed en bovendien de hellt van het bestedingsgereed maken. Wesseling acht dit een inbreuk op de opvatting dat van wanprestatie van de architekt kan worden gesproken wanneer deze niet binnen de afgesproken bouwsomilimiet ontwerpt. Hij leidt daaruit af dat de bouwsomlimiet een inspanningswerbintenis schept met als enige sanctie verbeurte van het honorarium voor dat deel van het honorarium dat tot het bestedingsgereed maken strekt. Verbeurte hiervan heeft dan $z$. 1 . voor dat deel een "no cure no pay" effekt, hetgeen m.i. volledig thuis hoort in de sfeer van de resultatsverbintenis die hier niet an de orde is. Uit de laatste regel van wesselings noot blijkt wel dat de situatie iets anders kan hebben gelegen dan uit de publikatie naar voren komt.

Vooral in dit soort geschillen wordt de uitspraak vak 
bepald door subtiele verschillen. Hier bifvoorbeeld door de mate van deskundigheid van de opdrachtgever, die kennelijk verschilde van die van het vorige geval.

Van wanprestatie is voorts nog tamelijk frekwent sprake bij het vervaardigen van uitvoeringatekeningen door de architekt, warin grove fouten zijn gemaakt (0.a. AIB 11-9-1974 BR 2975/553; AIB 25-11-1975 BR 1976/6I1; AIB 105-1982 BR 1982/912 - zie ook POG II G-73), of in de verdere teken al direktievoerder, b.v. bij onzorgvuldige eindoplevering. Deze gevallen komen bij de volgende paragraaf inzake aansprakelijkheid nog uitvoerig aan de orde.

Een bijzonder geval van wanpreatatie is het handelen in strija met art. 32 AR dat de architekt verplicht om bij het vervullen van zijn opdracht rekening te houden met publiekrechtelijke en privatrechtelijke voorschriften. Dat verwijt trof de architekt van een bouwplan dat wel een bouwvergunning verwierf mar wegens strijd met het bestemingsplan door G.S. werd geblokkeerd. Het AIB oordeelde echter dat opdrachtgeefster van het afkeuringarisiko op de hoogte was geweest en deed de architekt vrijuit gaan (AIB 8-11-1973 no. 67).

Eveneens vrijuit ging de architekt in een arbitrage op grond van hetzelfde artikel, omdat de opdrachtgever door reeds met de aannemer te kontrateren vobr de verlening van de bouwvergunning, zelf het risiko had genomen van extra kosten vanwege nadere eisen in relatie tot de bouwvergunning (AIB $29-4-1983 / \mathrm{BR} 83 / 736)$.

Het mag overigens verwondering wekken dat dit artikel 32 AR $71 / 183$ betrekkelijk weinig procedures tot gevolg heeft. De enorme vlucht in vooral publiekrechtelijke voorschriften verzwart de architektentaak zeer aanzienlijk. Om die reden zijn in de SR" 87 op deze takstelling restrikties a angebracht, welke de verplichting beperken tot het teltelijke bouwprojekt en vergunningen met een bedrijfstechnisch karakter, zoals de Hinderwetvergunningen, uitsiuten (art. $15 \mathrm{SR}^{\prime \prime} 87$ ).

Het niet verkijgen van een bouwvergunning door afkeuring van de Melstand leidt niet tot wanprestatie (art. $30 \mathrm{AR} 71$ ) (83). Ook in de $S R " 87$ (art. 5 lid 4) is toetsing van de vormgeving door de opdrachtgever voor de beoordeling van de takvervuling van de architekt uitgesloten.

Wanprestatie leidend tot onut woerbaarheid van de plannen op welke wije dan ook, als ook wanprestatie door het te lat leveren vah theningen wardoor vertragingsschade ontstat, zullen in de $S \mathbb{R}^{\prime} 87$ leiden tot ansprakelijkheid voor vermogensschade. 
V.2.4

prematuur werk

Onder prematuur werk wordt verstaan het doorwerken an de planontwikkeling van een bouwprojekt door de architekt, zonder dat de opdrachtgever zich realiseert hoever de voorbereiding van de uitvoering is voortgeschreden. Dat houdt in dat deze, bij vóortijaige beëindiging van de opdracht, veel méer honorarium moet betalen dan hij had gemeend verschuldigd te zijn.

In de $A R^{\prime} 71$ (en evenmin in de vö́rgaande regelen) is expliciete toesteming vereist roor het ingaan van een volgende opdrachtfase als genoend in art. 7 AR'71.

Integendeel, een eventueeel overgeslagen fase wordt geacht tot de opdracht behoord te hebben (art. 7 lid 2 AR'71). Dit heeft geleid tot hoogst onbillijke situaties die ook toenemende kritiek oogstten van de arbitrale colleges. Zie voor jurisprudentie POG II GII, $16,37,38$.

overigens lijkt het diskutabel of een dergelijk fenomeen onder de kwalifikatie wanprestatie thuishoort, immers is bij gebrek aan wilsovereensteming er eerder sprake van overprestatie. Dat latste zou dan kunnen leiden tot de onbestaanbaarheid van het betwiste deel van de overeenkomst op grond warvan honorering kan worden ontzegd.

In de SR'B7 is het voorkomen van prematuur werk vrijwel. onmogelijk gemakt, gezien de expliciete goedkeuring van de opdrachtgever voor de overgang nar de volgende fase van de opdracht.

V. 2.5

Aansprakelijkheid

V.2.5.1

aansprakel ijkheidsregelen in de $A^{\prime} 71 /{ }^{\prime} 83$ en $S^{\prime} 87$

De ansprakelijkheid van de architekt wordt geregeld in de art. $33 \mathrm{t} / \mathrm{m} 36$ van de Algemene Regelen. Deze bepalingen bevatten aanzienlijke beperkingen van de verbalismogelijkheden van de opdrachtgever $0 . g . v$. art. 1279 BW c. . $1401 \mathrm{BW}$. Deze bestaan uit:

- er moet sprake zijn van een ernstige fout ale de architekt met normale vakkennis bij normale oplettendheid en wijze van vakuitoefening had kunnen vermijden;

- er moet sprake zijn van schade als rechtstreeks gevolg van de genoemde fout:

- de omvang van de te vergoeden schade blijft beperkt tot de helft van het de architekt toekomende totale honorarium; 
- elke aansprakelijkheid vervalt na verloop van 10 jaren na de eerste oplevering van het werk:

- ex kan slechte spake zijn van vergoeding van de geleden chade indien en voorzover de opdrachtgever aantoont dat darvoor geen verhal op a annemer of leverancier mogelijk 1.5:

- overschrijding van de bevoegdheid tot het opdragen van meerwerk leidt tot aansprakelijkheid tenzijer sprake is van een spoedeisende voorziening met inachtname van het "nutsprincipe" "

Deze bepalingen hebben sinds de tweede wereldoorlog wel de nodige wijzigingen ondergaan. In de $A R \cdot 32$ (art. $20 \mathrm{t} / \mathrm{m} 33$ AR'32, geldig tot 1956) wordt nog wel geduid op de afwijking van $1645 \mathrm{BW}$, ten overvloede, omdat ook toen reeds vastond dat dit artikel niet op de ontwerpende architekt van toepasing was. De termijn van aansprakelijkheid was beperkt tot drie jaren, i.p.v. de huidige tien. Voor fouten van zijn personeel $\mathbb{i} s$ de architekt in het geheel niet aansprakelijk wanneer hij annemelijk kan maken dat hij deze bij normale oplettendheid niet had kunnen voorkomen of ontdekken. Weliswar ontbreekt de restriktie van de "ernstige" fout, doch de ernst van de fout weegt wel mee in de mate wan schadevergoeding, hoe groter bovendien de deskundigheid, hoe hoger de schadevergoeding. De konklusie is dan ook gerechtvaardigd dat ook minder ernstige fouten voor schadevergoeding in aamerking kwamen. Deze vergoeding kon destijds het totale honotariumbedrag niet overschrijden. Er stonden geen met name genoemde sancties op het overschrijden van de bevoegdheid terzake van het opdragen van meerwerk.

De huidige bepalingen dateren van de AR'56, met uitzondering van de huidige bepalingen in de AR'7l ten anzien van de voorrang van schadevergoeding ex art. 36 id 2 AR" $71 / 183$.

In de SR'B7 (art. 54) wordt de overschrijding van de bevoegdheid bij het voeren van direktie voor rekening en risiko van de architekt geacht, tenzij, zoals gebruikelijk, er sprake is van een spoedeisende voorziening. Voorts de gebruikelijke ansprakelijkheid voor rechtstreekse schade als gevolg van verwijtbare fouten of nalatigheden bij de ultwoering van de opdracht die een goed, zorgvuldig en met normale vakkennis toegeruste architekt had moeten vermijden (art. 53 lid 5 SR).

De termijn van aansprakelijkheid beloopt in de $S R^{\prime} 87$ vijf jaat na voltooing van de opdracht (art. 58 SR'87). In 1 id 2 wordt dit tijdstip nader gedefinieerd.

De omvang van de schadevergoeding wordt volgens de SR'B7 athankelijk geateld van het al- of niet volledig zijn van de opdracht (zie hiervoor hoofdstuk V.2.2).

V.2.5.2

de exoneratieclausules in de $A^{\prime} 71 / 183$ 
Ten aanzien van exoneraties in het algemeen is vooral na het HR arrest Saladin/HBU NJ $1967 / 261$ in de jurisprudentie een ontwikkeling opgetreden, al tendeerde het Moffenkit-arrest (HR 25-3-1986 NJ 1966/279) al duidelijk in dezelfde richting: tot 1957 gold dat de uitsluiting van aansprakelijkheid aan twee kriteria werden getoetst; strijd met de goede zeden of misbruik van omstandigheden (ekonomische machtspositie). Sinds het Saladin/HBU-arrest dient tevens rekening te worden gehouden met "de matschappelijke positie en de onderlinge verhouding van partijen", de zwarte van de schuld, mede i.v.m. de ard en de ernst van de bij enige gedraging betrokken belangen, de aard en de verdere inhoud van de owereenkomst warin het beding voorkomt, de mate warin de wederpartij zich van dit beding bewust is geweest en de wijze waarop het beding tot stand is gekomen. Daarmee doet de redelijkheid en de billijkheid hat intrede als rechtsoverweging. Dit zou ertoe kunnen leiden dat de exoneratieclausules in de $A R{ }^{1} 71 / 183$ zouden worden aangetast. In de jurisprudentio is daarvan tot op heden weinig gebleken. Een schadeclaim in het geval van een overschreden bouwsom 1 imiet werd afgewezen (AIB 28-5-1984 BR 1984/743).

Er bestaat een duidelijk verband tussen exoneratie en verzekerbaarheid (* 11). In het kader van de architektenovereenkomst moet dan onderscheid worden gemakt in het soort van fouten door de architekt gemakt. overschrijdingen van bouwsomlimieten of budgetten kunnen grote schade berokkenen, mar schadeclaims dienaangaande zijn niet verzekerbaar. Hoe duidelijker de architektenprestatie ligt in de sfeer van de inspanningsverbintenis, hoe moeilijker de werzekerbaarheid.

In dit verband is de diskussie interessant tussen Mr. ing. J. Kiers en Mr. H.C. Wesseling (* 12), warbij de eerste duidelijk makt dat de totstandkoming van het ontwerp en de toetsing aan een (overeengekomen) bouwsomilimet gekompliceerder is dan door veel juristen. wordt verondersteld. Dit leidt uiteindelijk tot de konklusie van Wesseling dat het halen van de bouwsomilmiet meer als een inspannings- dan resultatsverbintenis moet worden gezien. een mijns inziens juiste uitspraak. De verzekerbarheid van wanprestatie in dier voege is daarmee diskutabel gesteld. verschuift deze prestatie in de richting van de resultaatsverbintenis bijwoorbeeld een fout in het bestek. of een konstruktieve fout in werktekeningen dan is de verzekeringsmogelijkheid reeëler, al hoewel bevredigende polisvoorwarden nog niet bekend zijn: de dekking is a an restrikties onderhevig die een schijnzekerheld voor de opdrachtgever oproepen. Pas als een reële verzekeringsmogelijkheid aanwezig is kunnen exoneratieclausules verdwijnen (* 13), dat is in architektenkringen nog niet het geval.

De vermogenssituatie van de meeste architekten stat veelal in geen verhouding tot de mogelijke schadeomvang. Een overweging die ook in het Fokker-zentveld arrest (HR 
5-1-1968 NJ 1968/102) en rol speelde. Dat makt exoneraties in de $A R$ op dit moment helaas nog onvermijdelijk.

ook Hondilus ekent dat een keuze voor een stelsel van wettelifk onbeperkte ansprakelijkheid met een liefst verplichte verzekering voor het daaraan verbonden risiko, een te gemakkelijke konklusie zou zijn (* 11). Hijacht de partijwil, mar dan wel feltelijk aanwezig, van even groot belang. Hij wijgt exop dat de betekenis van het

a ansprakelijkheldsrecht voor de kwaliteit van het bouken niet moet worden overtrokken. Iedere deelnemer a an het bouwproces, en zeker de architekt zal goed werk willen leveren, terwijl voor zijn ondergeschikten de a ansprakelijkheid niet van doorslaggevende betekenis is. Bovendien kan een verzekering ook negatief werken, de drang goed werk te leveren zou er door kunnen verminderen.

Arisz komt in zijn pre-advies voor de NJV (* 14) tot de konklusie dat een wettelijk maximum per beroepsgroep een goed ujugangspunt zou zijn.

De goede trouw is in de beoordeling van het al of niet rechtmatig zijn van aansprakelijkheidsbeperkingen van grote betekenis. Dat impliceert dat van geval tot geval beoordeeld moet worden of en in hoeverre zulks het geval is, zoals uit het saladin/HBU arrest en Pseudo-Vogelpestarrest (HR $20-2-1976$ NJ 1976/486) blijkt.

Een van de overwegingen daarbij is, of de overeengekomen beperking in enige verhouding stat tot de voorzienbare schade. Grove schuld of aigen opzet makt in elk geval elk exoneratiebeding ongeldig, daarvoor zijn diverse arresten wan de Hoge Raad het voorbeeld. Voor het overige worden de kriteria die worden aangereikt in de bovengenoemde arresten en ook Saladin/HBU door de rechter niet frekwent gehanteerd. zie ook het Thermostatenarrest (HR 18-12-1981).

Aan het ontwerp NBW is toegevoegd een afdeling 6.5.2A onder de titel "Algemene Voorwarden". Daarin krijgt ook de exoneratieclausule aandacht. Uitsluiting van

a ansprakelijkheid doet een vermoeden ontstaan van onredelijk bezwarend te zijn (art. 4 sub f). Dit geldt echter alleen wanteer er sprake is van een "wederpartij", als natuurlijk persoon, die niet handelt in de uitoefening van beroep of bedrjf.

onredelijk bezwarend en ontbreken van goede trouw liggen dicht bij elkar.

Een integral verbod van aansprakelijkheidsuitsluitingen, een regeling van dwingend recht derhalve, kent nogal wat bezwaren, o.a. een te geringe flexibiliteit voor de bouw, zbals de Franse wet heeft bewezen. Nadere voorschriften over de wijze warop aansprakelijkheidsbeperkingen tot stand diemen te komen, geven ook lang niet altija een bevredigende oplossing, wals de Engelse en Duitse wet hebben getoond. cen tot nu toe enige Nederlandse geval van schadevergoeding 
op grond van een AIB uitspraak vindt men in: BR 1931 pag. 542 jo $\mathrm{Rb}$. Asd. $17-3-1982 \mathrm{BR} 82$ pag. 771 .

Daarbij zij echter aangetekend, dat de schadevergoeding niet werd toegewezen op grond van art. $33 \mathrm{AR}^{\prime} 71 /{ }^{1} 83$.

Van Wijngaarden (* 15) kritiseert art. 35 lid $1 \mathrm{AR}^{17 / / 83}$, warin de architekt aansprakelijkheid ultsluit voor door derden ontworpen onderdelen van het bouwwerk. Bij het realiseren van een bouwerk is thans, meer dan ooit, sprake van multidisciplinaire aktie, warvan de partners in het allergunstigste geval met goedkeuring van de architekt zijn aangesteld. Veelal heeft deze dar nawelijks inspraak in gehad, lat staan dat de keus door hem 1 is bepald.

Architektenkeuze.

Kan de architektenkeuze niet en grond zijn voor medeschuld aan een debacle van de opdrachtgever?

In de diskussies over wanprestatie en aansprakelijkheid van de architekt, valt het op dat er nooit de nadruk op wordt gelegd dat de opdrachtgever bewust een keuze heeft gemakt voor een bepalde architekt. Elke architekt heeft zijn sterke en zwakke kanten, niet elke sublieme vormgever is een even goede technikus, daarmee houdt een keuze ook een "berekend" risiko voor de opdrachtgever in. Dok voor de ingewijde opdrachtgever, of liever juist voor hem, is niet altijd de bouwsom een heilig principe, mar de esthetische kwaliteit van de schepping van de architekt.

V.3

Beslechting van geschillen

V.3.1

beslechting via de $A R$

voor geschilien tussen burgers stat de burgerlijke rechter ter beschikking. Krachtens art. 17 GW kan niemand tegen zijn wil van de rechter worden afgetrokken. Partijen kunnen echter overeenkomen om hun geschil niet aan de gewone rechter voor te leggen mar aan scheidsmannen. Daartoe dienen zij een akte van kompromis op te stellen waabij zij zich tevoren, of nadat het geschil is gerezen, uitspreken dat zij een dergelijke geschillenbeslechting uitdrukkelijk wensen. Een dergelijk scheidsgerecht is aan strenge wettelijke regels gebonden. Art. $620-657 \mathrm{Rv}$ regelt dat. Deze regelen zijn van dwingend recht (HR 27-4-1917, NJ 1917,

$687)$. Het acheidsgerecht kan uitesprak doen "naar de regelen des rechts" of "als goede mannen naar billijkheid" (att. 636 Rv).

Voor de tenuitvoerlegging van de uitspraak is men afhankelijk van de executoriale titel welke door een bevelschrift van de president van de rechtbank wordt verkregen: Daartoe moet de uitspraak binnen 8 dagen bij de griffie van de arrondissementsrechtbank worden gedeponeerd. Deze toetsing is echter van zuiver formele ara. 
Volgens de AR (en ook de afgeleiden RR en RT) worden deze geschillen tussen opdrachtgever en architekt via arbitrage beslecht (art. 47 AR), ook als éen der partijen dat als zodanig beschouwt. De BNA heeft daartoe lang geleden reeds een vast kollege in het leven geroepen.

Tot 1-1-1969 was dat de commissie van Geschillen, die ook vó́r 1940 reeds bestond. De samenstelling van deze commissie van Geachillen werd geregeid via de statuten van de BNA.

Tat 1948 bestond zij uit een voorzitter, welke gén beoefenal van het bouwvak mocht zijn en dertig leden, te weten:

- tien in het vije beroep werkzame architekten

- tien ambtelijke funktionarissen, die of zelf als architekt werkzam waren, óf wier werkgebied met het bowwen verwant was

- tien andere personen

De ledem wezen uit hun midden een sekretaris aan. De zittingstermijn van de leden was vier jaar, waarna zij terstond herkiesbaar waren.

per geschil werd een scheidsgerecht gevormd in gemeen overleg tussen partijen, of bij ontbreken darvan door de voorzitter, bestaande uit éen of drie leden.

Tenzij partijen dit overbodig achten wordt an thet scheidsgerecht een rechtsgeleerd raadsman toegevoegd met adviserende gtem.

Van 1948 tot 1957 wijzigt zich de omvang en de samenstelling van de Comrisie van Geschillen, er zijn dan 41 leden warvan:

- achttien in het vrije beroep werkzame architekten

- tien ambtelijke funktionarissen als in de vorige samensteling

- ten hoogste tien leden te benoemen door andere organisaties

- dertien "andere personen"

De sekretaris wordt door het hoofdbestuur van de BNA aan de Commissie toegevoegd. De verdere regeling blijft ongewijzigd.

Zo blijft de situatie tot 1969 .

Vanaf 1969 wordt de Geschillenbeslechting toevertrouwd aan de stichting Arbitrage-Instituut Bouwkunst (AIB).

Het voozitterschap en de samensteling van de lijst van arbiterg worden geregeld in art. 10 en 11 van de statuten van de stichting, er zijn in principe 45 arbiters bestaande uit:

- L4 architekten

- 3 adviseurs

- 11 personen uit kringen wit de overheid

- 5 personen uit het uitvoerend bouwbedrijf

- 2 diversen

- 10 vakatures (stand per mart 1986)

Het antal procedures houdt ongeveer gelijke tred met de toeneming van het aantal opdrachten: 
Toepasselijkheid arbitrageregels.

De toepasselijkheid van het arbitraal beding als onderdeel van de standaardregeling is nogal eens een punt van diskussie geweest. Het gaat daarbij primair om de vraag of de AR van toepassing is. Verwarrend is dat door architekten valk de honorariumtabellen van de AR worden gebruikt zonder dat de overige rechtsverhouding uitdrukkelijk door de AR wordt bepaald. In elk geval moet de $A R$ door partijen uitarukkelijk zijn overeengekomen (AIB 1970 nr. 24, BR 1971 pag. 171, ook: AIB $1971 \mathrm{nr} .1$, BR 1971 pag. 590 , NJ $1972 \mathrm{nr}$. 179). Veel architekten verwijzen onder aan hun briefpapier naar de toepasselijkheid van de $A R$ en de honorariumtabellen van de BNA. Het AIB acht dit voldoende om kennis te nemen van het geschil (AIB $1970 \mathrm{nr}$. 29). Een dergelijke beslisising stempelt de arbitrageregeling van de $A R$ tot een bestendig gebruikelijk beding. Naar het oordeel van de rechter kan een kompromissoir beding niet als zodanig worden beschouwd wanneer dat bij het aangaan van de overeenkomst niet met zoveel woorden is uitgedrukt.

"Ware het anders dan zou een partij door het aannemen van een rechtsfiktie tegen zijn wil afgetrokken kunnen worden van de rechten die de Wet hem toekent. Een dergelijke uitleg van art. 1383 BW zou in strijd zijn met het bepalde in art. 17 GW" (Rb Den Haag 27-2-1967).

vaste rechtspraak is dat een verwijzing naar de standaardvoorwarden al of niet met vermelding van de arbitrageclausule, in een vergevorderd stadium van het werk of bij de deklaratie, te laat is om daarop met sukses een beroep te doen. Noodzakelijk is het dechalve dat, wanneer een en ander niet uitdrukkelijk in de opdracht aan de architekt is vermeld, deze zijn opdracht bevestigd met verwijzing naar de toepasselijke regelen en het daarin opgenomen arbitraal beding. Het is tevens vaste rechtspraak dat, wanneer de wederpartij niet binnen korte tijd bezwar makt tegen deze bevestiging, deze geacht wordt stillwijgend met de inhoud akkoord te zijn gegaan. De vraag of arbiters bevoegd zijn kennis te nemen van het geschil, kan leiden tot eindeloze procedurekwesties wanneer niet duldelijk de arbitrageclausule is aanvard.

Partijen kunnen desgewenst een akte van kompromis sluiten, hetgeen arbiters in deze alsnog legitimeert.

Geheel of gedeeltelijke mietigverklaring van de arbitrale uitsprak.

Het staat partijen vrijom na een arbitrale beglising een beroep te doen op de gewone rechter terzake van nietigheid van de uitspraak, wanneer sprake is van:

- overschrijding wan de grenzen van het kompromis

- gebreken aan het compromis zelf

- onvolledigheid van het scheidsgerecht bij de uitsprak 
- wanneer sprake is van een uitaprak over zaken welke niet zijn geeist, of wanneer meer wordt toegekend dan gevorderd is

- bij tegenstrijaigheid van bepalingen in de uitspraak

- bij onvolledigheid van de uitspraak t.a.v. de punten bij komprontis bepald

- procedurefouten warvan nietigheid het gevolg is

- bij gebleken valsheid var atuken warop de uitsprak is gebasererd

- wanneer er sprake is wan achterhouden van stukken

- bij arglist of bedrog bij de beslissing of de procedures gepleega.

Dit alles ingewolge art. 649 RV.

Inajen bij rechterlijk gewijsde een uitspraak geheel of gedeeltelijk nietig is verklaard, dan wel onverbindend of is vernietigd, dan voorziet het Reglement AIB in een opnieuw a anhangig maken wanner de meest gerede partij zulks verlangt, mits iser zijn vordering binnen 6 maanden na het in kracht van gewijsde gaan van voornoemde uitspraak, instelt.

In de reglementer van de Comissie van Geschillen BMA van vobr 1969 zijn hiervoor géén voorzieningen getroffen.

overigens stelt Heemskerk (* 16) ten aanzien van art. 14 van het Arbitrage Reglement van het AIB, dat een dergelijke tweede instantie niet onder de algemene regel van art. 2 van het Reglement als een geheel kan worden gebracht, namelijk dat partijen geacht worden dit Reglement tot een onderdeel van hun overeenkomst te hebben gemaakt. Naar zijn mening kan een dergelijke regel slechts gelden voor de regels ten aanzien van de samenstelling van het scheidsgerecht en het verloop van de procedure.

Verzet tegen de arbitralle beslissing is niet mogelijk (art. 641 Rv) evenmin als hoger beroep, tenzij zulks is voorbehouden in de akte van kompromis door partijen en dan nog alleen in een zalk welke ook voor de gewone rechter appellabel zou ifn geweest (art. $646 \mathrm{RV}$ ).

Willen arbiters bevoegd zijn om uitspraak te doen, dan dient het arbitral beding door beide partijen uitdrukkelijk te zin a invard. De betwisting van deze bevoegdheld (op grond van art. $17 \mathrm{GW}) \mathrm{kan}$ arbitrale procedures, zoals eerder opgemerkt, eindeloos rekken. Als de gewone rechter eenmal. heett beslist dat ex van een geldige arbitrage-overeenkomst tussen partijen sprake is, dan zijn arbitars daaran gebonden. Door gedagde moet eon beroep gedaan worden op het arbitraal beding om aan berechting door de gewone rechter te ontkomen.

Spoedeisende zaken.

In geval van spoedeisende zaken is de president van de rechtbank bevoegd om een voorlopige voorziening te treffen in kort geding. Deze bevoegdheid blijft in stand ook bij aanwezigheid van een arbitraal beding (Rb Den Bosch 13-1- 
$1961 \mathrm{NJ} 1961 / 535$ en Rb Den Bosch 27-12-1973 NJ 1974/319). De vraag is gerechtvaardigd of er sprake is van en

konkurrentie met de genoemde procedize bij toepassing van de bepalingen van het Reglement ATF art. 12 inzake een

spoedgeschil.

Volgens Heemskerk ( $* 17)$ is dat niet het geval.

Immers het kort geding beoogt een voorziening bij voorraad en art. 12 een snelle definitieve oplossing van het geschil. Overigens beslist de voorzitter van het kollege van arbiters of.er sprake 1 s van een spoedgeschil, hij kan daartoe in dat geval verlof verlenen.

Weliswar verleent art. 11 lid 4 van het Reglement AIB de mogelijkheid van een voorlopige beslissing doch hiervan schijnt nimmer gebruik te worden gemaakt.

Gevolgde procedures.

Aangezien het vaak moellijk is vast te stellen of gebreken aan gebouwen te wijten zijn an ontwerpfouten van de architekt, aan verkeerde uitvoeringsinstrukties van het toezicht (architekt) of aan onjuiste uitvoering van de aannemer, worden de procedures voor AIB en die van de Rad van Arbitrage voor de Bouwbedrijven wel gevoegd.

In de praktijk werkt dat niet altijd even gumstig. Er ontstaan vaak problemen met de getuigenverklaringen, war immers zowel aannemer als architekt meestal de voornaamste getuigen $z$ ij $\mathrm{n}$ die als zodanig wel in gescheiden mar niet in gevoegde procedures kunnen optreden.

v.3.2

beslechting via bindend advies

Tot het bindend advies kan door partijen bij akte van compromis worden besloten en de uitspraak heeft dan de kracht van een overeenkomst welke partijen bindt. Een bindend advies is geheel lets anders dan een arbitraal vonnis. Het is niet omgeven met wettelijke warborgen. Een bindend advies is geen vonnis en kent geen executoriale titel. Bij niet-nakoming van de uitspraak kan wel een beroep op de rechter worden gedaan.

De uitvoering van een bindend advies kan door de rechter worden getoetst aan art. 1374 lid $3 \mathrm{BW}$. De GR heeft besilit dat niet in elke onjuistheid, die een in thet ongelijk gestelde partij in de gronden meent aan te treffen, een aanleiding gezien mag worden tot antasting van het bindend advies. Zuls kan alleen het geval zijn wanneer en en ander zo zeer in strijd is met de redelijkheid en billijktheid, dat van strijdigheid met de goede trouw gesproken kan worden (HR 29-1-1931 NJ $1931 / 317$ en HR $11-6-1965 \mathrm{NJ} 1965$ ) 258 ). Er wordt dus marginaal getoetst (* 18 ). 
De oorsprong van het bindend advies schijnt een artikel in de gemeentewet, voorheen art. $194 \mathrm{~h}$ jo art. $620 \mathrm{Rv}$, dat bepalde dat gemeenten, geschillen warbijzij partij zijn, zelf niet mochten onderwerpen aan arbitrage. Thans is daarin voorzien middels art. 228 i. van de Gemeentewet warin dadingen en arbitrage zijn toegestaan aan gemeenten, mits de goedkeuring dartoe van Gedeputeerde staten is verkregen.

In deze oorspronkelijke onmogelijkheid voor de overheid om geschilien via arbitrage te beslechten, ligt warschijnlijk de arnleiding om het bindend advies op te nemen in het

Reglement ran het Arbitrage Instituut Bouwkunst fart. 2 Iid 1 en 2).

Een dergelijke regel komt ook voor in het Reglement van de RAB.

Het bindend advies als wijze van geschillenbeslechting ataat juridisch in een niet zeer goede reuk. In de handel werd het gebruikt om verschillen van inzicht in de omvang van te verkopen goederen te bepalen (koffie). Het ging in dat geval om de bepaalbaarheid van hoever lheden en niet om de inhoud van de overeenkomst als zodanig. Bij de sluiting van het kontrakt stond al. vast dat een deel van de rechtsverhouding nader moest worden geregeld.

Wanneer het bindend advies wordt gebruikt t.b.w. de uitvoering van een overeenkomst, wanprestatie, nakoming, ontbinding of schadevergoeding; is er sprake van oneigenlijk gebruik.

Vaak kan echter ook een oneigenlijk gebruik van een bindend advies tot een goede regeling leiden. Er moet grote aandacht worden geschonken aan de oprechtheid van partijen om tot een oplossing te komen. Weigert een der partijen om het advies op te volgen dan ontstat een bijzonder moeilijke situatio, waruit slechts is te geraken via de kwade trouw al of niet als een fiktie (*19). Van alle gevallen warin van zulk een oneigenlijk gebruik sprake is, is die waar het gat om een in een afzondexlijk geval gesloten overeenkomst nog het minst onaanvaardbaar. In de rechtsverhouding opdrachtgever-architekt zal dat meestal het geval zijn.

Anders dan bij arbitrage acht men rechtsopvolgers onder bijzondere titel door het bindend advies niet gebonden. ook in het NBW wordt aandacht geschonken aan de beslissing van een derde, dus het bindend advies. Art. 7.15.7 lid 1 en 2 wijken echter niet af van hetgeen reeds door de HR in har arrest van $11-6-1965$ werd gesteld.

V. 3.3

beslechting via de rechtex

In gevallen warin de AR tussen opdrachtgever en architekt niet zijn overeengekomen, of warbij ingevalge art. 2 van het Reglement AIB geen akte van kompromis is gesloten dan 
wel een overeenkomst strekkende tot het verkrijgen van een arbitraal vonnis, dan wel bindend advies, kan de benadeelde partij terecht bij de gewone rechter.

Naar komend recht zal waarschijnlijk de keuzemogelijkheid van de opdrachtgever tussen arbitrage- kommissie of de rechter worden verruimd. Het is echter zeer de vraag of partijen darmee zijn gediend. De rechter kan bij tusaenvonnis een $\mathrm{zgn}$. deskundigenbericht vorderen, aangezien de onderhavige geschillen vaak te vakmatig zijn dat een rechter $z$ ichzelf zonder meer in staat zou achten daarover vonnis te wijzen.

Wordt én deskundige benoemd (of drie) dan heeft deze zich te houden aan de wettelijke regels die daarvoor $z i j n$ gesteld (art. 222 Rv e.v.).

Soms wordt, na benoeming van de deskundige bij akte ran kompromis, de zaak pas weer op de rol genomen wanneer een der partijen niet akkoord gat met het uitgebrachte bindend advies.

In feite is men als procespartij dan toch afhankelijk van een deskundig vakman en is er geen grotere rechtszekerheid dan bij bindend advies of arbitrage.

Bij de rechter komt men voorts terecht wanneer het arbitraal kollege onbevoegd wordt verklaard, hetgeen, zoals al eerder is gesteld, nogal eens voorkomt als gevolg van het onduidelijk zijn van de toepasselijkheld van het arbitraal beding bij het sluiten van de overeenkomst. Omgekeerd kan op dezelfde gronden de rechter de eiser niet ontvankelijk verklaren, waana de zaak wordt aanhangig gemaakt bij het arbitral college. Het is zelfs magelijk door te "pendelen" de procedure zeer lang te rekken (* 20 ). De gedaagde dient echter, zoals eerder gesteld, een beroep te doen op het arbitraal beding om berechting door de gewone rechter te ontgaan.

Spoedprocedures.

De president van de rechtbank kan in spoedeisende zaken een voorlopige voorziening bevelen in kort geding. Zulk een vonnis is witvoerbaar bij voorraad ondanks rechtsmiddelen in tegenstelling tot de spoedprocedure voor het AIB.

Van een rechterlijk vonnis is uiteraard hoger beroep mogelijk en eventueel kan worden gecasseerd. Een dergelijke procesgang is niet magelijk bij arbitrage via het AIB.

Een belangrijk arrest van de AR in een opdrachtgeverarchitektenprocedure is dat van HR 23-4-1976, BR 1976 blz. 610 warbij, bij wijze van uitzondering op de regel dat wie eist dient te bewijzen, de bewijslast voor het bestaan van een overeenkomst strekkende tot een opdracht voor een voorlopig ontwerp wordt gelegd bij de opdrachtgever en niet bij de architekt. 
V. 4

Praktijkontwikkelingen rond 1987

V.4. 1

de opdracht in het NBW

In het ontwerp-MBW wordt pok andacht geschonken an het begrip "opdracht" (Boek 7 titel 7 ). Onderstaand wordt a andacht besteed aan enige artikelen daaruit die van belang zijn voor de rechtspositie van de architekt.

Art. $7 \cdot 7 \cdot 1 \cdot 1$.

opdracht is de overeenkomst warbij de ene partij, de opdrachtnemer, zich jegens de andere partij, de opdrachtgever, verbindt buiten dienstbetrekking verichtingen te doen, die in iets anders bestaan dan het tot atand brengen van een stoffelljk werk, het bewaren van $z a k e n$, het uitgeven van werken of het vervoeren van personen of zaken.

Hierin wordt een duidelijk onderscheid gemaakt in de kwalifikatie van de overeenkomst $z i j$ het vanuit een negatieve redenering.

- er is géen arbeidsverhouding

- ex is geen sprake van het tot stand brengen van een stoffelijk werk etc., etc.

De kwalifikatie "verrichten van enkele diensten" is daarmee komen te vervallen. Het niet-stoffelijk zijn van de ard van de prestatie plaatst de architektenopdracht onder de inspanningsverbintenissen.

Art. $7.7 \cdot 1 \cdot 3$.

De opdrachtgever kan binnen het kader van de opdracht nadere aanwijzingen geven aan de opdrachtnemer.

Dit artikel houdt theoretisch in dat de opdrachtgever in de ontwerpfase, en ook daarna, invloed kan uitoefenen op het inspanningsresultaat. Weliswat wordt slechts gesproken van "nadere anwijzingen" maak deze kunnen voor de architekt grote gevolgen hebben, ook voor wat betreft de te verrichten prestatie.

Art. 7.7 .1 .4

1. - De opdrachtnemer moet tijdens de uitvoering van de opdracht de opdrachtgever op de hoogte houden en hem desgevraga inlichtingen over zijn handelen geven, voor zover dit, gelet op de aard van de opdracht, redelijk is.

2. - Zodra de opdrachtnemer de opdracht heeft volbracht, doet hij hiervan mededeling an de opdrachtgever, indien deze hiervan geen kennis draagt.

3. - De opdrachtnemer doet aan de opdrachtgever verantwoording van de wijze warop hij zich van de opdracht heeit gekweten, voor zover dit, gelet op de ara van de opdracht, redelijk is. Heeft hij bij de 
whoering van de opdracht ten late var de opdrachtgever gelden ultgegeven of te alens behoeve gelden ontangen, dan doet hil darvan rekening.

Artbelen van gelijke trekkng zin opgenomen in de sR*B.

A.t. 7.7 .1 .8$.

1. - Wancer twee of meer personen tezanen en opdracht hebben gegeven, $z i \ln$ zij hoofdell jk tegenover de opdrachtnemer ansprakel ju.

2. - Wanner wee of meer personen tezanen een opdracht hebben on vangen is leder van hen woor het geher ansprakelijk voor een tekortkoming in de nakoming. tenzif hij bewist dat de tekortoming niet an hem kan worden toegerekend an dat his niet natig is geweegt in het treffen van matregelen om de gevolgen darvan af te wenden.

Dit artikel is interessant in relatie met het ontwerpteam dat gezamenlijke verantwoordelijkheid dragt. De onkering van de bewijslast makt het minder antrekkelijk, zo het dat al ait andere hoofde is, om met en kollektieve werantwoordelifkheid te worden belast.

Art. 7.7 .1 .9

De opdrachenemex 3 bevoegd de atgifte van zaken die hij voor de opdrachtgever in verbanc met de utvoering van zijn opdracht onder $z i c h$ heeft, op te schorten. totdat hen zijn opeisbare vorderingen ter zake van de opdracht worden voldaan.

De enige afgifte van zaken warvan sprake 13 bij een acchitektenopdracht. is het afgeven van tekeningen of stukken op het ontwerp betreking hebbende. Bli een gescil over het honorarium kan de architekt derhalve zijh produktie opschorten of tekeningenafgifte blokkeren.

Art. 7.7 .1 .11

1. - Ieder der partijen is te allen tijde bevoegd zich wegens gewichtige redenen tot de rechter te wenden met het verzoek de opdracht te ontbinden. Een beding wardoor deze bevoegdheid wordt uitgesloten of beperkt, is nietig.

2. - Als gewichtige redenen worden beschouwd veranderingen in de omstandigheden welke van dien aard $z i j n$, dat de opdracht billijkheidshalve dadelijk of na korte tijd behoort te elindigen.

3. - De rechter wiligt het verzoek niet in dan na verhoor of behoorlijke oproeping van de wederpartij.

4. - Indîen de rechter het verzoek inwilligt, bepaalt hij op welk tijastip de opdracht eindigt.

5. - wordt de opdracht op verzoek van een partij ontbonden, dan kan de rechter aan de vederpartijeen naar de omstandigheden te bepalen schadeloosstelling toekennen. 
De ontbinding van de opdracht wordt nadrukkelijk aan de rechter voorbehouden. Een arbitraal beding in de standardvoorwarden is in dit geval niet van kracht. De overige bepalingen stroken met de artikelen van de SR'87, of vormen daarop aanvulingen die slechts algemene konsekwenties hebben voor de kontrakterende partijen in het algemeen.

V. 4.2

scheidslijnen in de planontwikkelingsfasen

De algehele praktijksituatie met betrekking tot opdelingen van opdrachten volgens, of zelfs binnen, de staffeling ex art. $5 \mathrm{AR}^{\prime} 76 / 183$ is zeer onoverzichtelijk. Enige duidelijkheid in ait beeld kan worden verkregen door de elementen, die de architektenovereenkomst bepalen, nader te analyseren in hun onderlinge relatie.

V.4.2.1

de opdrachtgever

De opdrachtgever speelt in de jurisprudentie een belangrijke rol vooral ten aanzien van het al of niet deskundig zijn op bouwkundig gebied. Ongelijkheid in kennis ten opzichte van de wederpartij speelt een rol bij de toetsing van de wilsovereenstemming. De konsument heeft immers recht op bescherming. Maar hoe is het eigeniljk met deze onwetendheid gesteld?

Immers, de argeloze burger die zich na moeizaam sparen aan de bouwmeester overlevert om $\mathrm{zich}$ van een stulp voor de oude dag te voorzien, behoort thans tot het verleden - hij wendt zich veelal tot het uitvoerend bouwbedrijf of een makelaar en niet tot de architekt.

"De" opdrachtgever is mondig geworden en weet vele wegen te bewandelen die hem, in zijn ogen, zekerheid verschaffen dat hij "war" voor zijn geld krijgt - value for money.

Architektonische warde speelt valk een ondergeschikte rol en is slechts van belang war dat kommerciële doeleinden dient en niet op gespannen voet stat met "het budget". Deze opdrachtgever, of $z i j n$ achterban/financier, heeft uitstekende toetsingskriteria tot zijn beschikking, hanteert standardmatstaven voor kritische onderdelen van het projekt.

De meeste opdrachtgewers, althans bij projekten van enige omvang, zijn professioneel en zo zij dat niet zijn, zijn $z i j$ in figurilije zin onder kuratele gesteld van subsidieverstrekkende instanties. De ontwerpen dienen te voldoen aan strenge kriteria die vaak in programmatische of financiele zin afhankelijk zijn van politiek. De formele opdrachtgever fungeert dan nog slechts als tussenstation. Een veelheid aan symposia en leergangen heeft potentiele opdrachtgevers, voorzover zij nog onbevangen waren, wegwijs gemakt in de doolhot van kontraktuele verplichtingen die 
de ontwikkeling van een bouwprojekt met zich mee brengt. Somige opdrachtgevers maken zich los van deze ingewikkelde materie, huren een professionele projektmanager in, bevestigen deze zelf-gekozen ondergeschikte positie door middel van een bevoegdheidsverklaring aan de projektmanager en gaan aan de zijlijn belangstellend toezien wie van het elftal de match zal overleven en in welk doel de bal terecht komt. Projektontwikkelaar, woningbouwcorporaties, organisaties op het gebied van bejaardenhuisvesting, het zijn alle opdrachtgevers in eerste of tweede instantie. die uitstekend bekend zijn met de praktijk van de planontwikkeling en die hun partners in dit proces weloverwogen kiezen.

Vooruitlopend op het verdere verloop van de opdracht breng ik nog onder de aandacht dat deze opdrachtgever weliswar vaak uit één (rechts) persoon bestaat, doch uit twee komponenten is opgebouwd: een investerende en exploiterende. $\mathrm{Zij}$ verlangen van de architekt een prestatie die tegengesteld is: een lage investering leidt onvermijdelijk tot hoge exploitatie en onderhoudskosten. Worden deze laag gehouden dan wordt valk het taakstellend budget overschreden. In beide gevallen kan zelfs sprake zijn van wanprestatie.

V. $4.2 \cdot 2$

de architekt

Het is natuurlijk bekend, dat de artistieke visie van architekten onderling per definitie verschilt. Daar echter ingevolge het gestelde onder art. $30 \mathrm{AR}$ "76/'83 de esthetische toetsing is uitgesloten ga ik hieraan voorbij. Deze toetsing is in $z^{\prime} n$ algemeenheid al niet bepalend voor de rechtsverhouding opdrachtgever-architekt. Zij ontbeert objektieve normen. Bij de beoordeling op welstandsaspekten spelen persoonlijke inzichten datroor een te grote rol.

Niet kan echter worden voorbijgegan aan het feit dat de architest-van-nu als kontraktpartij een grote mate van differentiatie kent. Meer en meer is de onvang van de opdracht, en niet wan het projekt, afhankelijk vari de te verwachten inbreng van de architekt en/of zijn bureau. Dat deze afhankelijk is van de omvang van het bureau en de mate van geoutilleerdheid lijkt evident, mar is dat nog niet. ondanks de kennis van de opdrachtgever worden vak nog uiterst lichtvaardig en op oneigenlijke gronden te grote opdrachten verstrekt a an daarvoor niet toegeruste architektenbureaus, hoewel deze in esthetische zin soms faam genieten als ontwerpers. In die gevallen behoort dan ook een deel van het planontwikkelingsrisiko c.g. uitvoeringsrisiko voor rekening van de opdrachtgever te komen.

Anderzijds zou het aanbeveling verdienen om tot meer 
Op deze pagina had de cartoon moeten staan van Peter van straaten uit Het Parool van 25 februari 1986, met het onderschrift:

"mar hoe komen jullie dan in vredesnaam aan die architekt?"

Desgewraagd heeft de heer van straten op auteursrechtelijke gronden zijn toestemming tot publikatie in dit proefschrift geweigerd.

De motivering daarvoor sproot voort uit zijn onverholen afkeer van architekten-in-het-algemeen;

hij geeft daarmee aan dat ook in 1988 nog steeds sprake is van de vooroordelen die al in Hoofdstuk I.1.2. worden gereleveerd. 
duidelijkheid te verplichten tot welke prestatie de onderhavige architekt in stat is alvorens hij een opdracht aanvardt. Ik heb het dan nog steeds over de gekwalificeerde architekt. Helaas opereren er nog steeds talloze nietgekwalificeerde architekten op de boumarkt.

Aangezien de matschappelijke positie van de architekt en dus ook zijn rechtspositie, wordt bepald door zijn kennen en kunnen, is woor de BNA de opleiding een zaak van acherpe a andacht. De invoering van de tweefasenstruktuur in het hoger onderwijs is mede anleiding geweest om in een voortdurende dialoog van het beroepsveld met de opleidingsinstituten te streven nat een optimum in de toerusting van de beginnende architekt. Dat zal een bron van zorg blijven omdat het streven naar verkorting van de studieduur stat tegenover een toename van de eisen voor wat betreft de vakkennis die de matschappelijke ontwikkelingen a an de architekt dikteren.

$v \cdot 4 \cdot 2 \cdot 3$

de opdracht

Over de struktuur van de aan de architekt verleende opdracht geeft de BNA-enquete "onwolledige opdrachten en betalingsgedrag" van 1983 een voldoende volledig beeld. Daaruit blijkt namelijk dat, naast de bekende splitsing tussen ontwerp- en uitvoeringsfase, een geheel skala van deelopdrachten voorkomt.

In de woningbouw wordt meestal opdracht gegeven voor het ontwerp en de bestektekeningen, maar de opdracht tot het maken van het bestek, de begroting, het houden van de aanbesteding, het voeren van dixektie en de eindoplevering is in meer dan de helft van het antal gevalien niet aan de architekt voorbehouden.

Een apart hoofdstuk van de in de $A R$ onder direktievoering begrepen werkzamheden zijn de werktekeningen. Men bedenke dat hierin de konstruktieve detaillering, warbijzich de meeste "fouten" voordoen, gestalte krijgt. In gemiddeld cen vijfde van de gevallen wordt deze deelopdracht niet aan de architekt die het ontwerp makt gegund. of het uitvoerend bouwbedrijf neemt dit voor zijn rekening óf de opdrachtgever bf een derde. Soms wordt de ontwerpende architekt met de "vormkontrole" belast, soms ook door het uitvoerend bouwbedrijf ingehuurd voor het maken van de werktekeningen voor het eigen ontwerp.

voor de utiliteitsbouw geldt dat vaker dan bij de woningbouw ook het bestek bij" de opdracht" behoort. Terwijl ook in mindere mate, ongeveer een derde van het aantal gevallen, de follow-up van de opdracht aan de architekt wordt onthouden, er is hier dus sprake van een grotere mate van volledigheid. 
Een en ander leert dat het begrip "opdracht van de architekt" verschilt in ard en omvang, dat die niet beperkt zijn tot de staffeling en omschrijving als genoemd in art. 5 AR en dat de begrenzingen zelts dwars door de $A R$ gegeven taakomschrijuing heen lopen.

De opdeling in kleinere brokken van de totaal-opdracht aan de architekt veroorzaakt een groot aantal breukviakken in het ontwerpproces die ad hoc ontstan. Dat bergt een kern van geschilien in zich ondat vaak niet duidelijk is hoe ver werantwoordelijkheden rejken en dus de aansprakelijkheid. Lang niet altijo wordt de opdeling van de opdracht veroorzakt door al of niet vermeende lacunes in de vardigheid van de architekt. Vaak spelen pur kommerciéle motieven een rol: men denkt daarmee op de plankosten te besparen.

Het laat zich gemakkelijk voorstellen dat in dit soort opdrachtsituaties, warbij veelal de AR als niet meer dan een leidraad fungeert, gemakkelijk kontraktuele situaties ontstan die een ernstige bedreiging vormen voor de cechtspositie van de architekt.

Meer en meer wordt er over de honorering van de deelopdracht onderhandeld, warbij niet de kwaliteit mar de prijs de keus bepalt dat is, war het toch gat om een $f$ inancieel equivalent wan een inspanningsverbintenis een hachelijke zaak. Zelfs komt het voor, dat aan meerdere architekten tegelijk offertes worden gevraagd zonder dat men daarvan onderling op de hoogte is. Zelfs de overheid ontziet zich daarin niet. Aangezien dit een regelrechte aanslag is op de kwaliteit van de beroepsuitoefening neemt de BNA thans een proef met de melaingsplicht voor de provincie Friesland. Een notaris fungeert als meldpunt, bij een dubbelmelding wordt een gesprek gearrangeerd tussen de aangezochte architekten. De resulaten zijn tot dusver niet ongunstig. Het laten vervallen in de $S R \cdot B 7$ van de minimumclausule in de honorering op basis van bestede tijd zal een landelijke invoering van de meldingsplicht warschijnlijk noodzakelijk maken. In het kader van de europese regeling zal. in een nog verder verschiet an een europese regeling evenmin te ontkomen zjjn. Dat makt een vroegtijaige oridntatie op de terzake geldende regelingen in de EGlanden dringend gewenst.

War bij de opdrachtverlening de AR expliciet wordt verlaten en vervangen door een op de specifieke situatie toegesneden tweepartijenovereenkomst bijift vak wel een acbitraal beding van kracht, zij het dat geen gebruik gemakt wordt van het Arbitrage Institut Bouwkunst. Het warom is niet recht duidelijk. Immers het Arbitrage Instituut Bouwkunst beslecht ook geschillen, zo gewenst, voortspruitend uit owereenkomsten die niet door de AR zijn bepaald. Men kan zich afvragen of de ervaring van dit instituut in de beoordeling van deze gekomplüceerde 
situaties kan worden gemist en of de rechtszekerheid van partijen daarmee is gediend. Hoewel delen van dergelijke overeenkomsten vak wel aan de AR worden ontleend, met name de aansprakelijkheidsartikelen, ontbreekt toch het evenwicht van een standararegeling als geheel.

Het zal duidelijk zijn dat de vertrouwenspositie ex art. I AR wordt gereduceerd tot de goede trouw die bij het angan van elke willekeurige overeenkomst gelat. Het dilema van de architekt is, dat juist hij die altijd degene bij uitstek is geweest die de integrale visie had op de ontwerpopgave als geheel, teruggedwongen wordt tot een deelfacet. Ook opdrachtgevers blijken te moeten wennen aan een door henzelf afgedwongen andere opstelling van de architekt, die ook hun noopt tot een scherpe definitie wan het doel en de aard van de te sluiten overeenkomst. Nu worat, hoewel de letter van de overeenkomst dat niet vraagt en de honorering er ook niet naar is, nogal eens de opstelling van de "architekt-oude-stijl" verwacht. Los van de vraag of deze verbrokkelde opdrachtsituaties ook de principal op de lange duur zullen bevredigen, kan wel worden gesteld dat de kwaliteit van de gebouwde omgeving er in elk geval niet mee is gediend: elk breukvlak geeft slipverliezen in kwaliteit, materieel en immaterieel, onverschillig welke a ansprakelijkheid voor wie daaruit voortvioeit.

Het minst schadelijk is nog een ontwikkeling waarbij de opdracht bestaat uit voorlopig ontwerp tot en met bestek en begroting, mits deze wordt uitgevoerd door een deskundig architekt die darvoor geëquipeerd is.

Er schuilt dus een ambivalentie in de enerzijds harde financiële afspraken die met de architekt worden gemakt en anderzijds het vaak niet scherp te definiëren resultat dat van $z i j n$ inspanning wordt verwacht. De bouwkostenkant is darvan nog de meest tastbare, zelfs zo dat in de kring van juristen stemmen zijn opgegaan of op grond daarvan de ontwerpopdracht niet als resultatsverbintenis zou moeten worden beschouwd. De bouwsomlimiet is echter in de volvoering van de opdracht meestal niet meer een begratingsprobleem maar een programmaprobleem. De kostenbewaking van de planontwikkeling is op het goed geèquipeerde architektenbureau zodanïg verfijnd dat verassingen bij de besteding beperkt kunnen bij juen tot marktmechanische schommelingen die helaas onwoorspelbar zijn en dat ook wel zullen blijuen.

Niet het ontwerp, doch vooral het bouwprograma met in haar kielzog kostenkonsekwenties, is gedurende de planontwikkeling aan fluktuaties onderhevig. Voeg daarbjo een groeiend aantal plan-beinvloedende beperkingen bij opdrachtaanvaarding en niet in te schatten risiko ${ }^{\circ}$ in de zin van subsidieverstrekkingen. milieu-aspekten en aspekten van ruimtelijke ordening, dan kan de architektenprestatie 
moeilijk anders worden gezien als een inspanningsverbintenis. Dat makt het grootwte deel van de architektenopdracht onverzekerbaar, en daardoor, exoneraties onvermi jaelijk.

Een geheel andere ontwikkeling valt te verwachten als gevolg van de voortschrijdende automatisering op het architektenbureau. Daarmee wordt in eerste instantie het geautomati eerd ontwerpen bedoeld. De geintegreerde gegevensverwerking en kostenbewaking tijdens de ontwikkelingafasen van het bouwplan bergt een tendens in zich tot koncentratie van aktiviteiten op het achitektenbureau. Dat zal dan wel geautomatiseerd noeten ontwerpen, daarbij niet aldeen de eigen gegevens hanterend, mar tevens die van de mede-ontwerpende disciplines in de installatiove sektor.

Het ligt voor de hand dat deze bundeling in elk geval zal plata vinden tot aan de besteding. Met de ontwikkeling van het sTABUmbestek in relatie met de besteding zelf, ilgt de koppeling in het verschiet van geautomatiseerd ontwerpen en geautomatiseerde kontrole op het uitvoeringspraces.

Men bedenke daarbij steeds dat ontwerp, boutechniek en kosten een onverbrekelijke eenheid vormen.

De rol van de standaardvoorwarden in relatie tot de deelopdracht antwikkelt zich als volgt:

de AR is verouderd mar, $z i j$ het met anpassingen ad hoc, in de thans zich voordoende kontraktsituaties wel

hanteerbaar als richtlijn. Als bindend voorschrift is zij echter niet bruikbar meer.

De SR $i$ thans meer dan tien jaar in ontwikkeling mar heeft de eindstreep ondanks de politieke stellingname van de Minister van Ekonomische Zaken vrijwel gehaald. De schets van de kontraktsituaties in het beroepsweld zal duidelijk hebben gemakt dat de $S R^{\prime} 87$, zaals ze thans is geformuleerd, darop een adequat antwoord kan en moet wormen.

Met name de fasering van de opdracht zal zo moeten zijn dat het architektenbureau optimal kan funktioneren in het hele gkal van soorten opdrachten. Een standaardregeling moet nit leiden tot verstaring mar dient een flexibiliteit in kontraktvormen toe te laten, binnen een duidelijke begrenzing.

Een goed a anknopingspunt voor een definitie van het begrip tekeningen vormt het ontwerp-normvoorschrift

"tekeningen in de bouw" NEN 2574. Een verfijnde staffeling in fasen die hierin wordt voorgesteld, bevat bovendien een omschrijving van de eisen waraan deze tekeningen inhoudelijk moeten woldoen. Het kan een goed uitgangspunt vormen voor eenduidigheid in de door de architekt te leveren prestatie. Bij de formulering van de inhoud van de 
fasen in het SR" 87 heeft dit normwoorschrift dan ook model gestaan.

De gegevenswerstrekking komt bij dit normvoorschrift in hoofazak te liggen vbor de a anbesteding. Dat kont de ordening op de boummarkt ten goede, zij het dat de daarmee geparad gaande vốrinvestering in ontwikkelingskosten door de opdrachtgever niet met vreugde zal worden begroet. ook werd door de overleggroep "Ordeningsthema's Aanbestedingswezen juni $1982^{\circ}$ " in het rapport "Naar een ordening op de bouwmarkt" immers gepleut voor meer en duidelijker gegevens bij de a anbesteding.

De opdrachtgever ziet $z i c h$ echter, bij niet doorgaan van het projekt, gesteld voor hoge deklaraties van de ontwerpende disciplines. Tach lijkt het juister het risiko van een fallend projekt niet te leggen bij de ontwerpers of uitvoerders-in-spe, doch bij degene die het planinitiatief nam, gesteld tenminste dat het niet-doorgan niet a a hún prestatie is te wijten.

Een ander aspekt is het thans in koncept geformuleerde toezicht op de standaardwoorwarden volgens het NBW. Het is an te raden om de verdere ontwikkelingen wan de $S R$ regelmatig te toetsen aan kriteria die in de toekomst zullen worden gesteld. Dat zou kunnen gebeuren door een kommissie die nat dat toekomstig model nu reeds zou kunnen worden gevorma. De bij de invoering van het NBW dan verkregen wettelijke status van de $S R$, zal de 2 ekerheid geven van de toepasseligkheid in opdrachtformulexingen van de architekt.

Er zij nog op gewezen, dat de architekt niet altija per definitie de spil van het bouwproces hoeft te zijn on zijn specifieke bijarage te leveren. Dat hangt van de a ard van de bouwopgave af. De standaravoorwarden dienen zodanig geformuleerd te worden dat de inbreng van de architekt op een natuurlijke wijze kan worden ingepast in het ontwikkelingsproces al naar gelang de noodzaak daartoe wordt gevoeld. Zij kan niet via standaardvoorwarden worden afgedwongen. Het besef van die noodzakelijkheld moet voortkomen uit enerzijas het kulturele bewustijijn, anderzijds het onderkennen van kriteria in bellevingswarde. ook daarop zal de BNA in de toekomst meer nog dan in het verleden hat a andacht dienen te richten, omdat daarvoor steeds minder begrip lijkt te bestaan. Men bedenke echter de uitsprak van bouwmeester Mieras: "de tija araat geen dieper merkteken dan dat der architektuur". Tekortkoiningen in kulturele warde zal ons door komende generaties terecht kunnen worden verweten.

V. 4.3

koncentraties var partijen in de ontwerpfase

ook uit de vorige paragraaf is duidelijk gebleken dat vooral de ontwerpfase wordt gekenmerkt door vele differentiaties in kontraktwele celaties. over het algemen 
werkt de opdrachtgever deze verwarde situatile zelf in de hand. Wanneer het echter tot geschillen en ansprakelijkheidsvragen komt worden de konsekwenties daarvan eerst recht zichtbaar, en wordt de roep om duidelijkheid in de verantwoordelijkheden luider.

Er zijn in grote lijnen twee situaties te onderscheiden:

- het bouwteam, warmee bedoeld wordt een koncentratie van ontwerpende disiplines met de uitvoerenden vobr de a anbesteding, al of niet met aktieve inbreng van de opdrachtgever

- het ontwerpteam, warin alleen de ontwerpende disciplines zijn vertegenwoordigd, weer al of niet met aktieve inbreng van opdrachtgeverskant en warbij de totstandkoming van het koncept een gemeenschappelijke verantwoordelijkheid is.

$v .4 \cdot 3.1$

het bouwteam

Het ophemen van de aannemer in het planontwikkelingsproces ontstond in de vijtiger jaren uit de overweging dat daardoor in de na-oorlogse woningbouw efficienter en goedkoper kon worden gebouwd. Efficienter ondat specifieke konstruktiesystemen die door de uitvoerenden werden gehanteerd in de ontwerpfase konden worden geintegreerd. Goedkoper omdat in opeenvolgende fasen een kortingsregeling van kracht was wanneer deze door het inschakelen van de aannemer vóbr de besteding beter op elkaar zouden ansluiten. Op die wijze werd een kontinue bouwstroom veilig gesteld. Daarvoor moest wel met de aannemer een ramovereenkomst worden gesloten.

ook in de utiliteltsbouw komen bouwteams van deze aard voor, zij het minder uit bouwekonomische, dan wel uit $6 f$ technische, of tijdoverwegingen. Bij werken warbij de aannemerskeuze sterk wordt bepald door het daarvoor beschikbare speciale materieel, is het voor de hand liggend om het ontwerp daarop af te stemmen. De prijsvorming zal dan op open begroting dienen plats te vinden, tenzij meerdere ultvoerenden over deze specifieke uitvoeringstechnieken kunnen beschikken. In dat laatste geval kan een overeenkomst met de aannemer worden gesloten warin zijn. mee-ontwerpende rol na het gereedkomen van het ontwerp eindigt en er aen open situatie ontstaat warin een besteding op uitnodiging kan platsvinden.

Anderg ligt dat wanneer een bouwteam wordt gevormd uit tijasoverwegingen. Het komt voor dat in het kader van goedkeuringsprocedures of subsidietermijnen zeer snel moet worden anbesteed terwijl nog slechts een definitief schetsplan voorhander is. De prijsstelling is veelal gellimiteerd, zodat bij een prijsvorming op open begroting met én arnemer tijdens de uitwerking nar bestek en bestektekeningen een belangrijke tijdwinst kan worden 
gemakt. Bij een dergelijke werkwijze is uiteramid een afstandverklaring van de aannemer onontbeerlijk. Tevens kunnen dam bezuinigingen reeds tijdens de bouwvoorbereidingsfase worden geintegreerd in het ontwerp, wat ook de architektonische kwaliteit zeer ten goede komt.

De voorkeur van opdrachtgevers voor de bouwteangedachte is in het algemeen nogal afhankelijk van de konjunkturele omstandigheden. In tijden van recessie en daarmee gepara gaande verscherpte konkurcentie zal men minder geneigd zijn zich vroegtijdig vast te leggen op sen annemer. In tijden van hoogkonjuktuur daarentegen zal men in de voortijdige samenwerking met de utvoerenden een garantie zien voor een redelijk peil van de aanneemsom.

Hoe rationeel een dergelijke samenwerking ook mag zijn, de a ansprakelijkheden bij tekortkomingen in het gerede produkt 1 iggen niet erg duidelijk, en dienen van geval tot geval te worden bezien.

Duhoux stelt in 1970 (* 21) dat, waar sprake is van planontwikkeling, de architekt in laatste instantie verantwoordelijk is, voorzover geen sprake is van specifieke verantwoordelijkheden van de overige deelnemers aan het bouwteam, en voor planuitvoering de a annemer. Daarbij wordt uitgegaan van een passieve rol van de opdrachtgever en een ontwerpopdracht via de $A R$, wat in de huidige situatie lang niet altijd het geval is. Immers, wanneer sprake is van een aktieve rol van de opdrachtgever in het ontwerpproces ligt dat anders. Hij is dan medeverantwoordelijk geworden door zijn participatie (AIB 23-6-1972 BR $1973 / 393$ en RAB 6-7-1982 BR 1982/715 e.v.). Daaromtrent dienen bij de samenstelling van het bouwteam zeer duidelijke afspraken te worden gemakkt. Verder is het zo dat iedere andere deelnemer verantwoordelijk blijft voor zijn specifieke inbreng en de kontraktuele regels warbij die is geregeld; het optreden in bouwteamverband doet daaraan niets af ook al worden bes 1 issingen in algemeen overleg genomen.

Partijen doen ex goed aan om hun eventuele bezwaren tegen in teamverband gekozen oplossingen, vast te leggen in de verslagen van de teamvergaderingen en in ernstiget gevallen schriftelijk kenbaar te maken aan de opdrachtgever.

In eerste instantie zal de opdrachtgever moeten bepalen op wiens specifieke gebied de fout is gemakt. Hamaker atelt dat de specifieke verantwoordelijkheden van de deelnemers in het bouwteam overgaan in een gemeengchappelijke omdat de scheidslijnen niet duidelijk te markeren zijn (* 22).

V. 4.3 .2

het ontwerpteam

Dat het ontwerp roor een gebouw van enige ingewikkelheid tot stand komt via een multidisciplinalr ontwerpproces is evident. Gebeurt dat zonder de uitvoerende partijen dan 
heeft, ter onderscheiding van het bouwteam, de kwallikikie ontwerpteam de voorkeur.

Van groot belang is daarbij hoe de juridische positie van de participanten is geregeld, omdat datmee uiteraard ook verantwoordelijkheden worden vastgelegd.

In de $S R^{\prime} B 7$ is de mogelijkheid opgenomen om én van de ontwerpende disciplines (in dit geval uiterard de architekt) alg opdrachtnemer te laten fungeren die de gemeenschappelijke vecantwoordelijkheid draagt van het gehele tean.

Het voordeel daarvan is de grote duidelijkheid voor de opdrachtgever, hij hoeft bij problemen niet uit te zoeken wile verantwoordelijk is.

De terugkeer nar de mogelijkheid van één kontraktuele relatie tussen opdrachtgever en ontwerpteam is een absolute noodzaak. De rechtszekerheid van de opdrachtgever eist dit in het geval van multidisciplinair ontwerpen.

Reeds in 1976 heeft Van den Berg voor een zodanige konstruktie gepleit (*23).

Eerstens wordt daardoor de opdrachtgever gesitueerd op de plats war hij thuis hoort, zonder vermenging met de opdrachtnemers, al kan hij de facto wel bij de ontwikkeling worden betrokken in organisatorisch verband.

In de tweede plats worden de verantwoordelijkheden van de opdrachtnemer duidelijk.

Deze opdrachtnemende kontraktpartij zal de verantwoordelijkheden met $z i j n$ mede-antwerpers goed moeten regellen. De afstemming van aansprakelijkheden uit hoofde van SR en van RVoI is daarbij noodzakelijk, en ook doorgevoerd in de $S R^{\prime} 87$.

Het lijkt eenvoudiger als opdrachtnemer niet uit te gaan van de ontwerpgroep-als-geheel, mar van de daartoe meest geeigende discipline. Deze sluit op zijn beurt

afzonderlijke kontrakten met de nevendisciplines. Dat levert ook in juridische zin de meest duidelijke situatie op. Bijft éen der overigen in gebreke, dan kan hij binnen de groep worden gesubstitueerd, wonder direkte gevolgen voor de overigen.

Bif een zo duidelijke juridische konstruktie is thet evenens overbodig om de door Van den Berg voorgestelde onafhankelijk adviseur an te stellen als beslisser bij geschilien binnen het tearm. De beslisser is de feitelijke hoofdkontraktant.

Door Van den Berg gesuggereerde oplossingen voor een juridisch verband in het ontwerpteam middels de matschapskonstruktie $z i j n$ om hiervoor reeds genoemde redenen tot mislukken gedoemd: daarvoor zijn er per definitie te grote verschilien in praktijkuitoefening. 
v. $4 \cdot 3 \cdot 3$

de ontwerper als kontraktpartij van de a annemer

Hoewel de juridische positie van de architekt hierbij in wezen niet verschilt van andere situaties, is het wellicht zinvol hierbij toch even stil te staan. Nast het felt dat de aannemer natuurlijk ook kan optreden als "gewone" opdrachtgever van de architekt, kan hij ook de hulp inroepen bij het aitbrengen van een "turn-key"-offerte. De offerte-uitbrengende partij blijft daarbij risikodrager en de architekt $z a l$ er goed aan doen $z i j n$ rechten goed te regelen bij het niet-doorgaan van het projekt. Ook dit pleit voor flexibel hanteerbare standaardvoorwarden. 
In de periode 1945-1985 zien verschillende variaties op de AR'32 het 1icht: 1956, 1964, 1969 en 1971. Dat wekt de schijn dat er wordt ingespeeld op de matschappelijke onrust die beschreven is in hoofdstuk IV. Niets is echter minder war, de op die tijdstippen ingevoerde wijzigingen kunnen nawelijks meer dan aanpassingen worden genoemd. Zij zijn juridisch gezien, zelfs in het geheel niet

interessant. Toch groeit rond 1965 het besef dat op de oude voet niet kan worden voortgegaan. In 1967 wordt een

schuchtere poging gedaan voor het formuleren van een écht nieuwe rechtaverhouding. Het zal echter nog 21 jaar duren voor die ontwikkeling tot resultat leidt.

Het struikelblok is niet de beroepsgroep zélf, mar de grote opdrachtgevers en het Rijk die hun invloed als grootste opdrachtgevers willen doen gelden. De

achteruitgang in matschappelijke wardering voor de architekt komt daarin op pijnlijke wijze tot uiting.

pas als, om politieke redenen, (zie hoofdstuk V.1.2.1) het Rijk zijn greep op de ontwikkeling verliest wordt er

resultaat geboekt en komt in zeer korte tijd een rechtsuerhouding tot stand die niet meer een aangepaste AR is, als voorheen, mar is geschreven vanuit een matschappelijke visie.

Daarin zijn zelfs kenmerken terug te vinden van de a anbevelingen van de allereerste werkgroep die in 1967 is begonnen met het nieuwe koncept.

Architekten hebben dus wel degelijk een visie.

De "Titelwet", de bescherming van de titel van architekt, komt in deze periode in een eindfase. Dat betekent dat het 86 jaar heeft geduurd, van de eerste, juridische, aanbeveling (Bruynzeel's 20 e steling in zijn dissertatie van 1900) tot realiteit. De door Bruynzeel tevens voorgestane beroepsbescherming heeft de matschappelijke diskusie echter niet overleefd, zij vindt in de Titelwet geen plaats. Somigen betreuren dat, anderen, waronder ook vakgenoten, niet. In hoofdstuk I. 2.2 is niet voor niets geschetst hoe beropabescherming aan zichzelf ten onder kan gath.

De negatieve benadering vanuit het matschappelijk gebeuren heeft ook reperkussies voor de meest voorkomende juridische diskusiepunten uit het architektenkontrakt. De

jurisprudentie keert zich, zij het vooralsnog schoorvoetend, meer tegen de architekt. Zijn vertegenwoordigingsbevoegdheid wordt, ook nu weer, kritisch bejegend, vooral war het financiele zaken betreft. Rond de arasprakelijkheid van de architekt wordt de diskussie zo fel, dat vooral dit punt in de nieuwe rechtsverhouding breder wordt opgezet.

De jucidische kwalifikatie van het architektenkontrakt in 
relatie met het fenomeen wanprestatie komt in het licht van de schijnwerpers te staan, en vormt een anleiding roor diskussie. De exoneraties worden getoetst aan het wetsontwerp Algemene Voorwarden.

De aanval vanuit de juridische hoek noopt tot tegenstand. Het vastberaden doorzetten van de nieuwe standaardregeling is een eerste stap op de weg nar een beter evenwicht in juridisch, en ook matschappelijk opzicht.

De praktijkontwikkelingen aan het eind van de onderzoeksperiode laten een grotere differentiatie zien van kontrakten en pseudokontrakten voor delen van de architektenopdracht. Een zadanige ontwikkeling is niet gunstig: elk scheidingsvlak herbergt een potentieel konflikt omdat de grenzen van de a ansprakelijkheid in deeltaak-gebieden niet scherp en helder zijn te definièren. Hier liggen matschappelijke en juridische ontwikkelingen zeer dicht bijeen. Er bestaat nog te weinig jurisprudentie over om trends te kunnen formuleren. 
1. BNA rapport

2 Aanbiedingabrief

3 Rapport CHH BNA

4 prof. mr.

A. R. Bloembergen

5 prof. mr.

W.C.L. van der Grinten - BR 76 pag. 71

6

prof. mr.

C.A. Adriansens

$7 \mathrm{mr}$.

M.A. van Wijngaarden

$8 \mathrm{mr}$.

M.A. van Wijngaarden - idem blz. 17

9 o.a. CVG 24-6-69 nr. 70

10 CVG

11 prof. mr.

E.H. Hondius

\section{BR 1984}

13 A.R. van Nes

14 Arisz - Kamphuisen

$15 \mathrm{mr}$.

M.A. van

$16 \mathrm{BR}$

17 BR

$18 \mathrm{mr}$. H.G. van der Werf

19 Cremers-zonderland

20 prof. mr.

W.H. Heemskerk

21 H.K. Duhoux

22 prof. dr. J. Hamaker

$23 \mathrm{mr}$.

M.A.M.C. van der Berg
- Analyse onvolledige opdrachten en betalingen - Amsterdam 1983

- rapport cie Herziening Honorariumregeling BNA 16-12-1968

- par. 2.01 e.v.

- Vertegenwoordiging blz. 2 Tjeenk wilink 1981

- Praktijkboek onroerend Goed II G-87/KI. uwer-Deventer

- Hoofdstukken Bouwrecht nr. 7 Tjeenk willink Zwolle 1987

- AIB 10-12-76 nr. 80

- 10-10-1968 nr. 19

- "aansprakelijkheidsbedingen in de bouw BR $1979 / 581$ e.v.

- blz. 568

- NJB 1963 blz. 713 e.v.

- pre-advies NJV 1987 deel 1 blz. 61

- Aanneming van bouwwerken en architektenovereenkomst,

Tjeenk Willink Zwolle, blz. 83

- $1976 \mathrm{blz} \cdot 129$

- 1976 blz. 135

- "Redelijkheid en billijkheid in het contractenrecht",

Gouda-Quint blz. 75

- Bouwrecht E II 2

- BR 1976 blz. 134

- Rechtsverhoudingen tussen deelnemers an thet bouwpraces, BR 1970 blz. 183

- Enkele aspekten van de samenwerking in een multidisciplinair ontwerpteam $I$, BR 1976 blz. 86

- Enkele aspekten van de samenwerking in een multidisciplinair ontwerpteam, BR 1976 blz. 92 
AUTEURSRECHT EN DE BOUWKUNST

VI. I Korte historie van de wetgeving op het Auteursrecht met betrekking tot de Bouwkunst

VI.2 De architekt en de Auteurswet 1912

VI.3 De juridische definities van de Auteurswet 1912 met betrekking tot de bouwkunst

VI.3.l de ard van het auteursrecht

VI.3.2 de maker van het werk

VI.3.3 werken warop auteursrecht bestaat

VI.3.4 het openbaar maken en verveelvoudigen

VI.4 Overige bepalingen van de Auteurswet

VI.4.1 openbaarmaking en verveelvoudiging

VI. 4.2 beperkingen

VI.4.3 het "droit-moral" of persoonlijkheidsrecht VI.4.4 handhaving van het auteursrechtstrafbepalingen

VI.4.5 duur van het auteursiecht

VI.5 Het auteursrecht en de Algemene Regelen voor de honorering van de architekt en de verdere rechtsverhouding tussen opdrachtgever en architekt $\left(A^{171)}, \mathrm{c} \cdot \mathrm{g} \cdot \mathrm{SR} \cdot 87\right.$

VI. 6 Notenlijst

VII Konklusie

Literatuurlijst 
VI. 1

Korte historie van de wetgeving op het Auteursrecht met betrekking tot de Bouwkunst.

De gedachte dat de voortbrengselen van de kreatieve geest bescherma dienen te worden tegen gebruik of misbruik doar anderen, en dus bescherming behoeven, heeft maar langzaam vaste vorm aangenomen.

De eerste sporen ervan schijnen terug te vinden te zi in in de pritolleges die door vorsten en stadsbesturen aan bepalde schrijvers en graveurs werden verleend.

Een stap nat een meer algemene regeling was het decreet der "Provisionele Representanten" van het volk van Holland uit 1795, warbij speciale persoonlijke privileges werden afgeschaft omat $z i j$ in strijd waren met de toen aangenomen algemene grondbeginselen van beveiliging van het rechtmatig eigendom van elk individu. De oorsprong van deze privileges gaat terug tot ca. 1500. Drukkers vroegen en kregen van de overheld deze voorrechten met betrekking tot de uitgave van een bepald werk voor een bepalde periode. Niet de auteur maar de verspreider ontleende hieraan zekerheid.

Het decreet bleef van kracht tot 31 mei 1803 en werd later uitgebreid in 1808, wardoor het nadrukken en uitgeven van boeken werd geregeld alsmede de rechten met betrekking tot gegraveerde platen, portretten, landkaarten en topografische afbeeldingen.

Ti jdens de Franse overheersing warin de Franse auteursrechten van 1791 en 1793 rechtstreeks golden, werd deze wet buiten werking gesteld en eerst na herstel van de onafhankelijkheid trad de wet van 25 januari 1817 in werking warin de rechten werden geregeld met betrekking tot "het regt van kopij of van kopieeren door den druk "van de atureur".

Omdat er geen definitie werd gegeven van het begrip "kunstwerk" en slechts de "druk" als middel van vermeniguldiging a an de orde kwam, alle andere procedés onbesproken latende, voldeed de wet allerminst. Reeds in 1835 overwoog men wijziging, aie uiteindelijk eerst in 7881 uitmondale in een nieuwe wet "houdende bepalingen tot regeling van het auteursrecht". Deze wet regelde echter alleen het auteursrecht op "geschriften, plat-, kaart-" muziek- en toneelwerken, zoomede mondelingen voordrachten". De beeldende kunst kwam er niet in voor, iets wartegen in 1879 Jozef Israëls en andere Haagse kunstschilders in een adres an de Tweede Kamer hadden geprotesteerd. De regering was echter van mening dat deze kunstuitingen een andere benadering vergden, wartoe zij een apart wetsontwerp op 
19 februari 1884 indiende bij de Tweede Kamer. Op

3 december van dat jar volgt nog een herindiening, mat helaas vervalt het ontwerp als gevolg van een

Kamerontbinding .

Op 27 juli 1886 wordt het opnieuw anhangig gemaakt bij de Kamer, met een herindiening in oktober 1887 , maar behandeling bleef uit. Op 28 maart 1889 richt de Matschappij tot Bevordering der Bouwkunst en adres a an de Minister warbij zij aandringt op behandeling van het wetsontwerp uit 1887, mar dan met de uitbreiding van par. 1 art. I door niet alleen te spreken over tekeningen en modellen" mar tevens over "werken der Bouwkunst". Zonder resultaat. Men bleek zeer bevreesd dat een dergelijke bepaling verlammend zou werken op het matschappelijk leven.

Het geruchtmakende "Woerdense plagiaat"zie blz. 264, warbij de burgemeester van Woerden begeesterd door het raadhuis van Noordwijk (architekt Nic. Molenaar), dit in spiegelbeeld in zijn eigen gemeente liet neerzetten door zijn ambtenaren, bracht het auteursrecht op gebouwen een stapje nader.

Jhr. de stuers zag er aanlelding in om er in de kamerzitting van 08-12-1903 ruime andacht van de Minister voor te vragen. Deze Woerdense stadsbestuurder heette Schalij, hetgeen voor de stuers aanleiding was voor de opmerking: "sedertdien verander ik de ij in een $k$, want ik vind hem een grooten schalk".

zonder resultaat.

De Maatschappij tot Bevordering der Bouwkunst had bescherming van de bouwkunst in een adres aan de Koningin op 16-11-1904 wederom bepleit met een terugverwijzing naar een eerder adres aan de Minister (1889). Op 17 oktober 1910 werd de Maatschappij verzocht om opnieuw een adres te zenden an de Koningin terugwijzend natr dat van 1904 .

September 1904 - Arti et Amicitia zendt een adres an de Koningin om regeling van het auteursrecht te bepleiten, en nederlandse toetreding tot de Berner conventie. Deze Conventie was gesloten op 9 september 1886, aangevula in 1896. Nederland was met Turkije het enige land in Europa dat geen deel uitmakte van de conventie. Bij de herzieningskonferentie in 1910 te Berlijn is Nederland woor het eerst vertegenwoordigd door een delegatie onder leiding van mr. dr. Snijder van Wissekerke. In 1911 is de Nederlandse toetreding een feit.

op 9 februari 1912 wordt de wetswijziging op het Auteurscecht ingediend die in overeenstemming is met de Berner Conventie. Daarmee werd een bevredigend resultat bereikt, doch wijziging van de bouwkunstige wecken vielen niet onder de bepalingen. De reden datroor was: "in den regel primeert het praktisch, het nuttig, karakter boven het artistiek: de toepassing van dit artikel op deze werken 


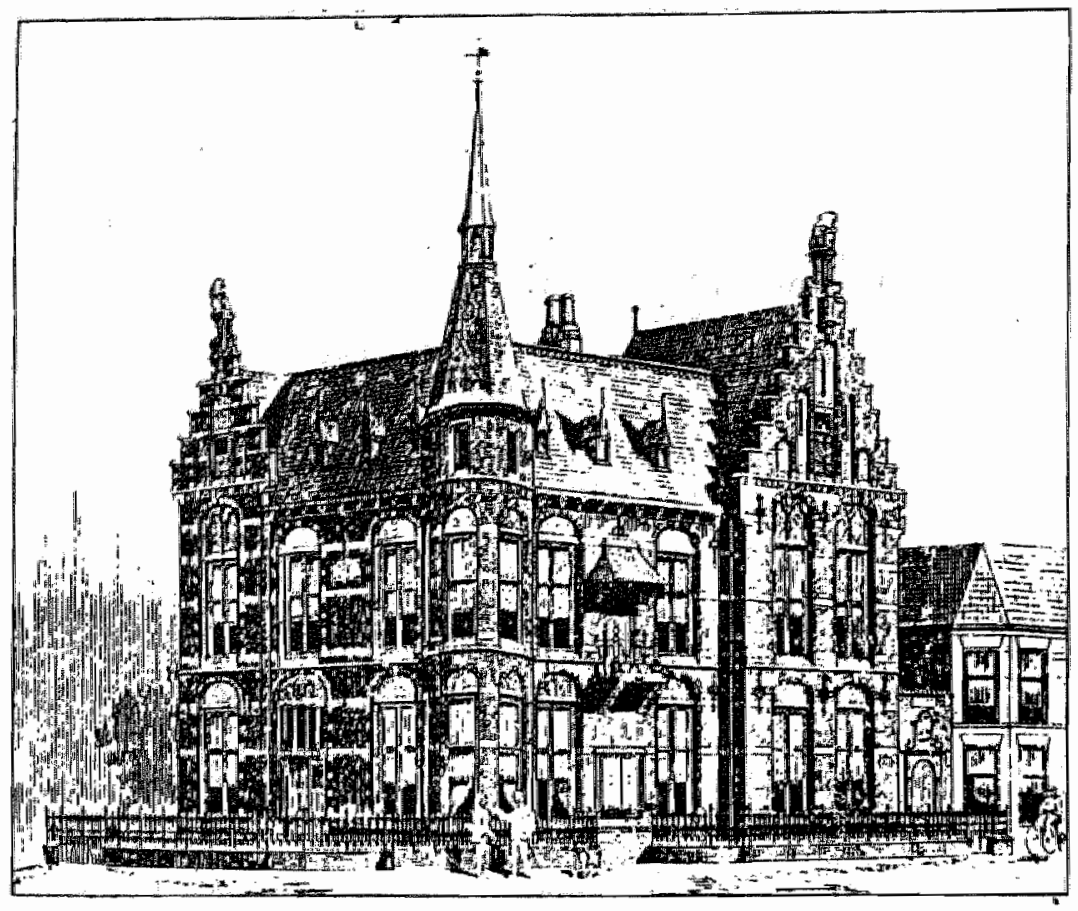

RAADHUIS TE NOORDWIK.

Arch. NiC. MOLENAAR.

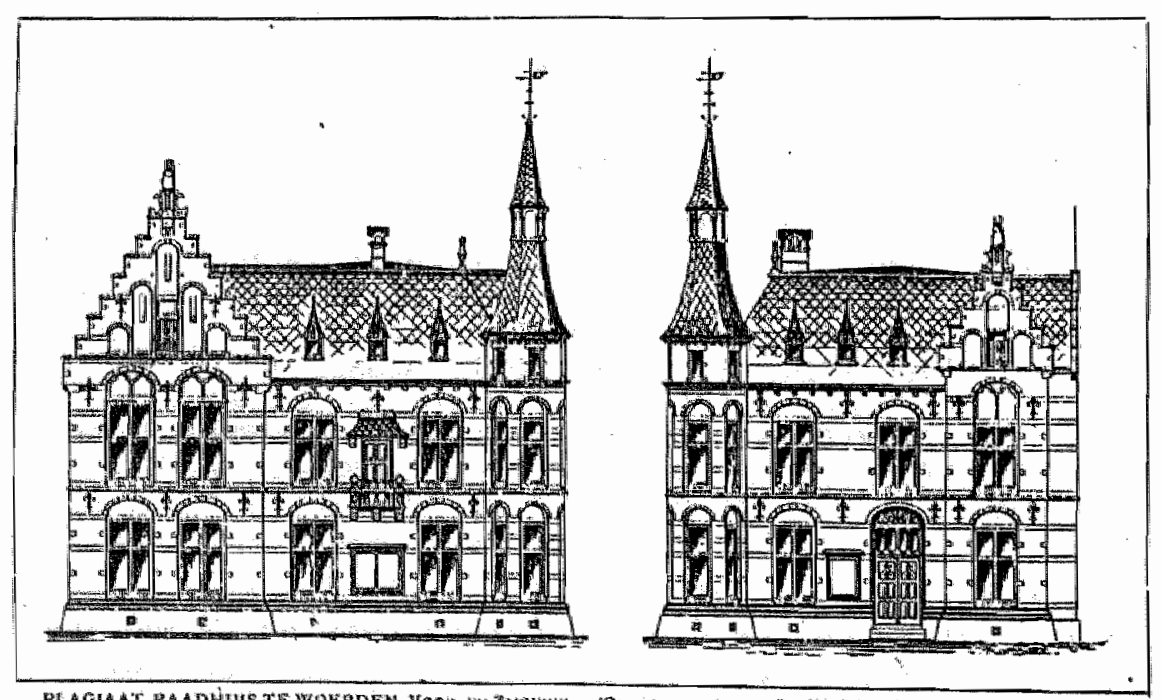

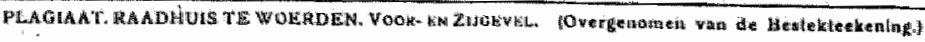

U1t: Bouwkundig Weekblad. 1912 


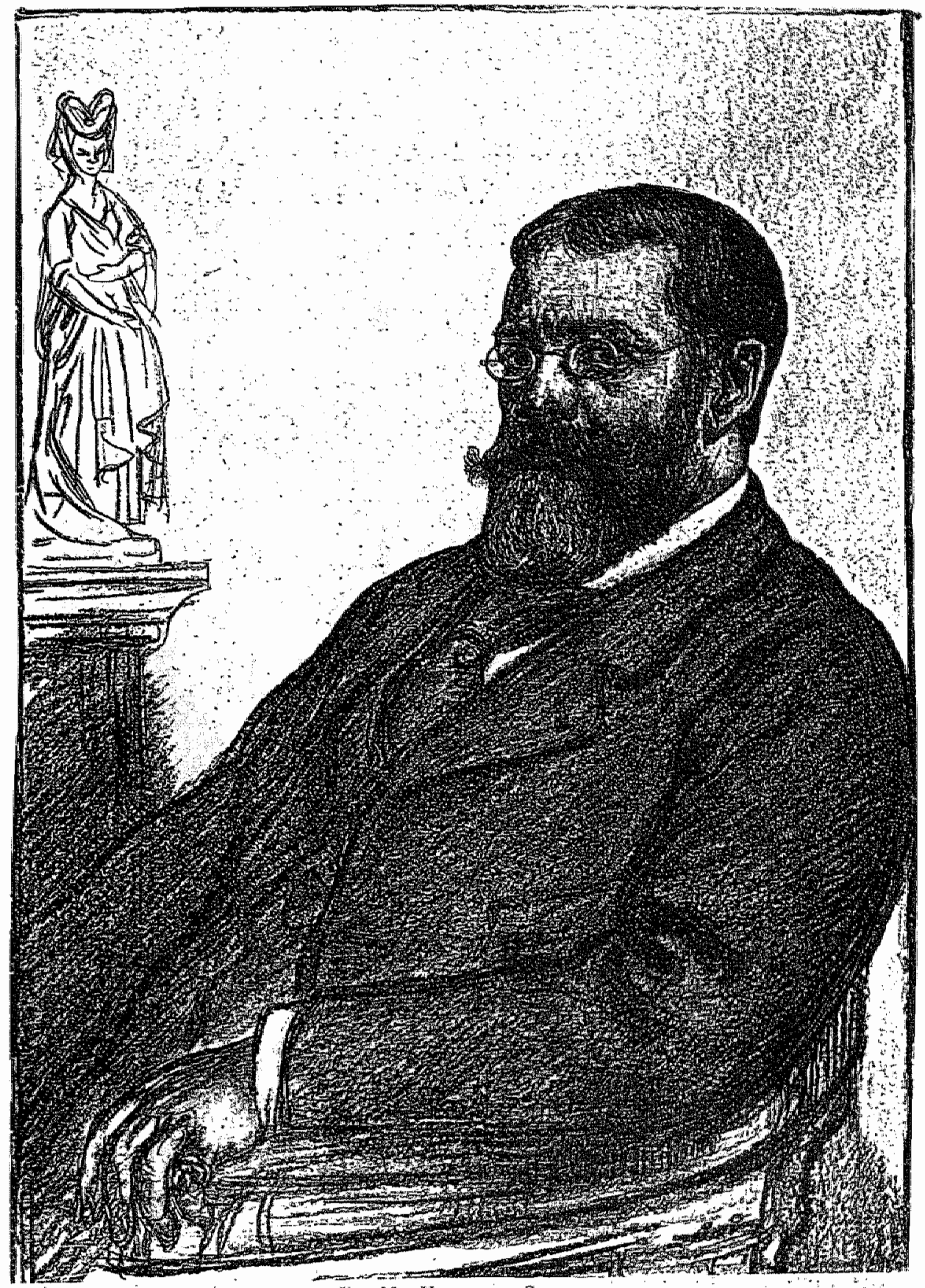

Jhr. Mr. WiCtOR DE STUERS, 


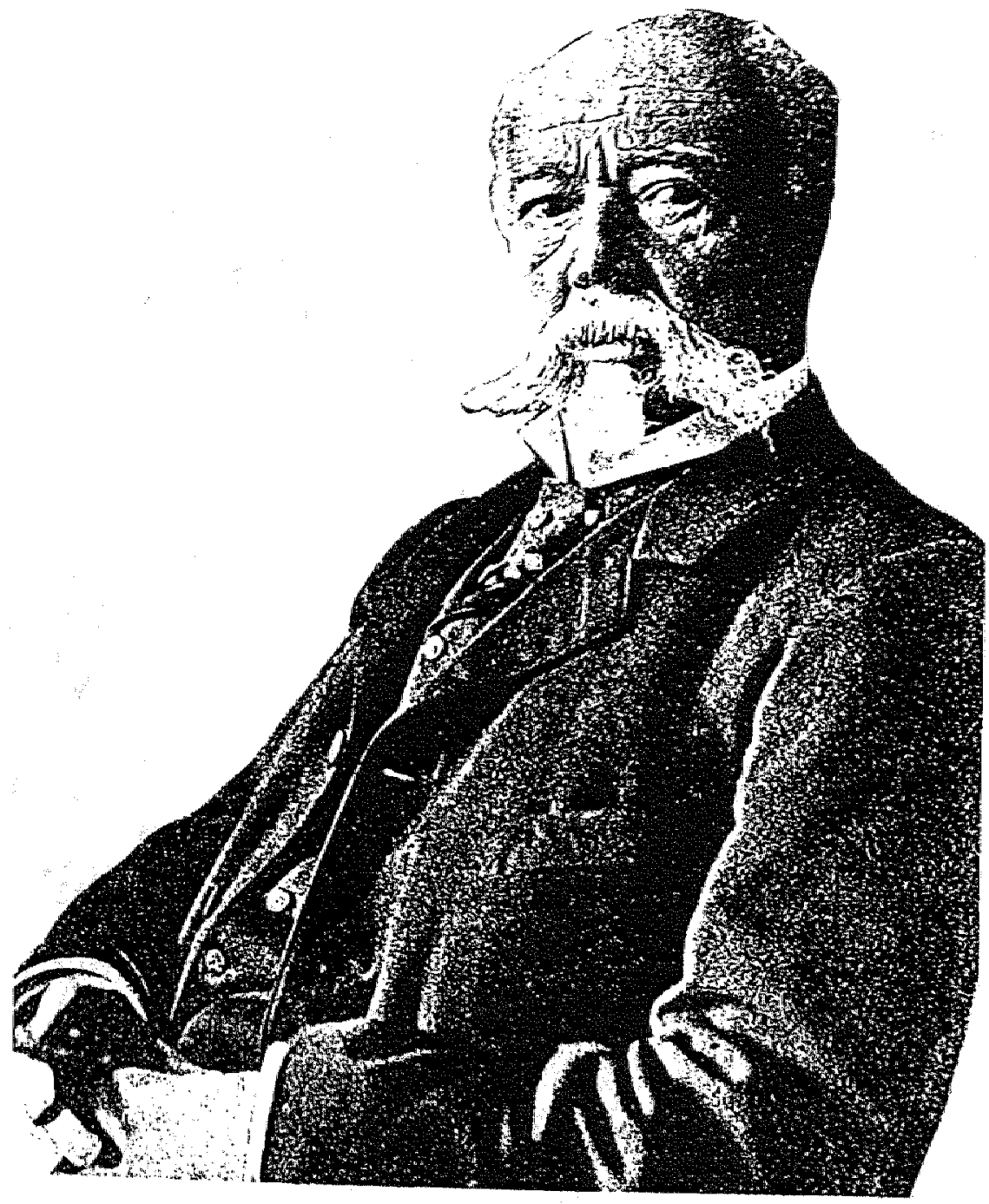

M. W. SCHALEY, Burgemeester van Woerden $\mathrm{ISS}_{3}-\mathrm{I}$-OS. 
zou in de practijk vaak tot onoverkomelijke moeilijkheden aanleiding geven" (Memorie van Toelichting 1912 ).

Op de internationale architektencongressen "te Brussel 1897 Parijs 1900, werden resoluties aangenomen woor de gelijkstelling van de bouwkunst met de andere beeldende kunsten. Madrid 1904, Londen 1906, Wenen 1908, wensten uibreiding tot de bouwwerken zelf. Men argumenteerde ala volgt:

1 "que les dessins d'architecture comprenant les dessins des façades extérieure et interieure, les plans, coupe et l'elevation, et les detalis décoratifs, constituent la première manifestation de la pensée de l'architecture et l'oeuvre d'architecture" :

2 "que 1'édifice n'est qu'une réproduction, sur le terrain, des dessins d"architecture".

Zonderland heett hierop in onze tijd nog ernstige kritiek (* 1 ). Hij stelt dat wij nog steeds opgescheept zitten met het feit dat deze Weense motie werd aangenomen. Hij wijst erop dat het in sub 2 gestelde verder gat dan uit de overeenkomst opdrachtgever-architekt logischerwijze voortvloeit, orndat het de opdrachtgever slechts door de architekt uit hoofde daarvan zou worden toegestaan het plan éenmaal te realiseren. Daartegenover kan men stellen dat het niet gaat or de stoffelijke vertaling van het papieren plan. maar om de geestelijke prestatie, al of niet gerealiseerd. In dat licht gezien is het tweede deel van de motie zeer konsekwent.

Pas bij de wetswijziging van 1931 werden ook veranderingen aan bouwwerken onder de wet gebracht en werd de bouwkunst geheel gelijk gesteld met de overige kunsten.

De wetswijziging van 1972 is niet van belang geweest voor bescherming van werken van bouwkunst voor fotografische verveel voudiging zonder voorafgaande toesteming (art. 18 AW, zie hoofdstuk IV.4.2).

VI. 2

De architekt en de Auteurswet 1912

In de totaliteit van de Auteurswet 1912 nemen de "werken der bouwkunst" een bescheiden plats in, maar niettemin een specifieke. Dit speciale karakter worat veroorzakt door de gebondenheid van deze kunstvorm aan materie en funktionaliteit, meer dan welke andere van de overige kunsten. Die gebondentheid heeft zoals wij zagen de bouwkunst lang verhinderd haar plaats in het auteursrecht in te nemen.

Een belangrijk facet van de Auteurswet is het in het algemeen veiliggtellen van de materielle belangen van de maker van een werk, direkt of indirekt. 
Van plagiat kan slechts sprake zijn wanneer het de strikte originaliteit van en bouwerk zou betreffen. Zeker nu. waa $x$ de atandaardisering van bouwprogramm's en ook van de architektonische detaillering hand over hand toeneemt en door overheid en ook opdrachtgevers dwingend aan de architekt wordt opgelegd, lijkt dat minder relevant. Deze leiden immers sowieso tot uniforme oplossingen in de planmatige en konstruktieve sfeer. De originaliteit van het ontwerp blijft derhalve veelal beperkt tot de groepering en kompositie van standara-eenheden die, aangezilen die van geval tot geval stedebouwkundig bepala zijn, niet gauw voor kopiêring vatbaar zal zijn.

Het belang van het auteursiecht voor de architekt is veeleer gelegen in het feit dat, hoewel dat niet primair het oogmerk van de wet is, er een bescherming tegen aantasting van het werk zelf aan kan worden ontleend via het persoonlijkheidsrecht van de maker (droit moral). Hoewel de Auteurswet in hat geheel natuurlijk ook de bouwkunst ten dienste stat zijn er bepalde facetten in opgenomen die door de matschappelijke invloeden wat van kleur veranderen in de tijd. Veelal hebben deze facetten daardoor in de loop der tijden tot diskussies aanleiding gegeven. Onderstaand wordt daarvan artikelsgewijs een overzicht gegeven.

\section{3}

De juridische definities van de Auteurswet 1912 met betrekking tot de bouwkunst

VI. 3. .

arard van het auteursrecht

- Art. 1, "het auteursrecht is het uitsluitend recht van de maker van een werk van letterkunde, wetenschap of kunst, of van diens rechtverkrijgenden, om dit openbaar te maken en te verveelvoudigen, behoudens de beperkingen bij de wet gesteld"

Het doel van het auteursrecht is derhalve primair gericht op bescherming van de rechten van de maker, niet op bescherming van het geestesprodukt zelf. Daarbij gaat het bij bouwkunst om drie hoofdelementen:

- verveelvoudiging (o.a. plagiat):

- openbaarmaking (in bijzondere gevallen het bouwen z6If, mar meestal met betrekking tot het verspreiden wan foto"s van bouw werken of modellen warop auteurstecht bestaat)

- aantasting (inbreuk op het gebouwde ontwerp).

De rechten met betrekking tot verveelvoudiging en openbarmaking zijn voor overdracht vatbar, geheel of gedeeltelijk, mits dit geschiedt door middel van een authentieke of onderhandse akte. Het recht op verweer tegen aantasting behoort onder het zogenaamde "droit moral" 
oftewel persoonlijkheidsrecht, en is ingevolge de Berner Conventie niet voar overdracht vatbaar. ook al zijn de auteurgrechten overgedragen, de toesteming voor ingrepen in het oorspronkelijk werk van de maker blijft veteist, mits hij in leven is, of aan de door hem bij uiterste wilsbeschikking of codicli a angewezene.

VI. 3.2

de maker van het werk

- Art. 4, wie is de maker? De wet baseert zich primair op wie op het werk als zodanig staat aangeduld. Een enkele mal ziet men inderdaad nog wel eens een naam van een architekt ergens op een gebouw, meestal in het buitenland, hetgeen hem als maker legitimeert, zie blz. 270. In art. 46 van de Algemene Regelen voor de honorering van de architekt en de verdere rechtsverhouding tussen opdrachtgever en architekt is dit recht dan ook duidelijk vastgelega in de overeenkomst opdrachtgever-architekt. Ten opzichte van derden zal de maker wel moeten bewijzen dat hij de maker is, wil hij zijn rechten geldend maken. De maker is in alle gevalien de geestelijke schepper, aus niet zij die de uitvoering verzorgen.

- Art. 5, regelt het auteurschap wanneer er sprake is van een samenstel van werken van kunst uit afzonderlijke werken van twee of meer personen. Wichers Hoeth grijpt voor een bouwkunstig voorbeeld terug naar Phidias als bouweester van het parthenon (*2), die geassisteerd werd door verschillende kunstenaars. Of hier sprake is van afzonderlijke werken die een integrerend deel vormen van het bouwwerk, een vereiste, lijkt diskutabel. Weliicht is het Erechtheion met de (dragende) kyriatiden een beter voorbeeld. zover teruggrijpen is echter niet nodig. In de huidige architektenpraktijk is immers het "ontwerpteam" een veel voorkomende vorm. Veelal zijn hier meerdere ontwerpende disciplines bij betrakken, soms zelfs uitvoerende. Wanneer men de technische disciplines van het ateurschap uitsluit, amat het "esthetisch element" daarin ontbreekt ( $* 3$ ) resteren nog de lnterieurarchitekt en soms de participerende kunstenaars. Art. 5 spreekt nast het auteursrecht van leder van deze participanten op hun deel van de schepping, ook nog van een maker als degene die met de "leiding en het toezicht bij de totstanabrenging van het gansche (ontwerp) werk" is belast geweest, of hij die de verschillende werken verzameld heeft.

Het komt echter thans ook wel eens voor dat het nilet de architekt is die met dit "verzamelwerk" is belast. Het algeheel makerschap kont dan toe an de verzamelaar, en de architekt heeft dan alleen rechten voor zijn beperkte, esthetische, inbreng. Of daarbij dan nog sprake is van een 

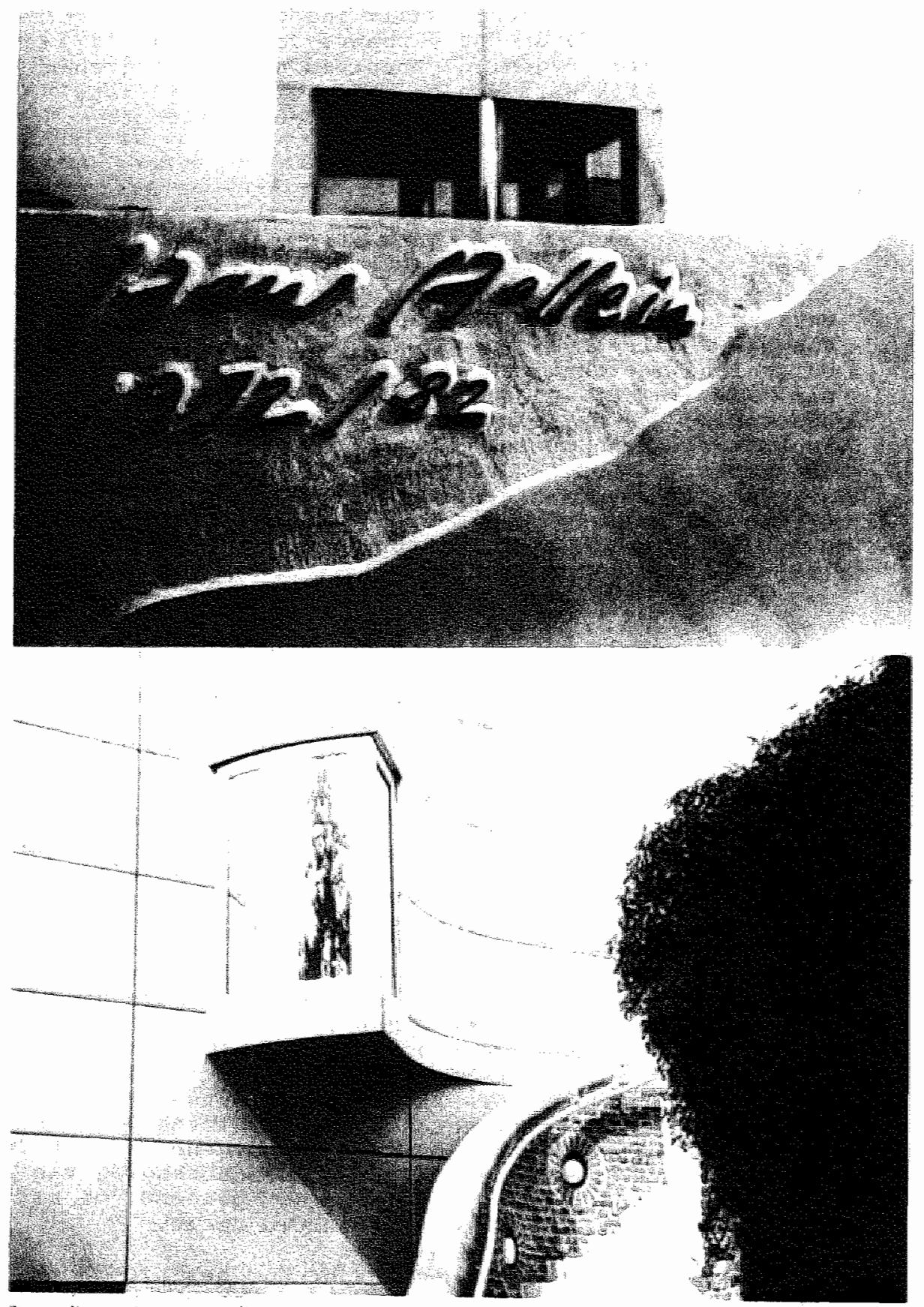

Een "gesigneerd" gebouw:

het museum te Monchen-Gladbach

van Hans Hollein (AR, dec. 1982) 
werk in de $z$ in van het auteurscecht is op zichzelf al de vraag, gezien de definitie als "een in warneembare vorm belichaamoe schepping" (*4).

Met het vervagen van de grenzen der disciplines die bij het ontwerp betrokken zijn zou de interpretatie van dit wetsartikel wel eens bijzonder moeilijk kunnen worden in het licht van de herkenbaratid van de prestatie. In de Mvi op de wet in 1912 wordt slechts verwezen naar de simpele situatie van het architektonisch ontwerp in samenhang met beeldende kunstenars.

- Art. 6. "indien een werk tot stand is gebracht nat het ontwerp van een ander en onder diens leiding en toezicht, wordt deze als de maker van dat werk a angemerkt".

Zowel Wichers Hoeth (*5) als Haardt (*6) zien hierin een regeling van het auteursrecht bij samenwerken van architekten op ongelijke voet (buiten dienstverband want dat valt onder de artikelen 3,7 en 8 ).

De konklusie lijkt gerechtvaardigd dat dit artikel in het geheel geen betrekking heeft op architekten, maar op andere beeldende kunstenaars, n.1. beeldhouwers. Het komt in die kringen veelvuldig voor dat de hoofdvorm wordt bepaald door de kunstenaar mat dat het feitelijk hakken door free lance steenhouwers gebeurt onder leiding van de kunstenaar. Hetzelfde doet zich voor bij het bronsgieten.

Bij architekten komen zulke situaties in het geheel niet voor, tenzij voor het uitwerken van een bestaand ontwerp een uitzendkracht zou worden ingeschakeld, dan wel een ontwerper van een collega-architekt zou worden geleend. Gezien de aard van het ontwerpwerk zal dat niet veel voorkomen, en kwam dat zeker niet voor ten tijde van de totstandkoming van de wet.

- Art. 7 en 8, ontwerpwerk in dienstverband kent, tenzij anders is overeengekomen, geen auteursrecht. Dat komt toe an de werkgever als natumrijke- of rechtspersoon. Niet als werkgever in de zin van het auteurstecht wordt aangemerkt hij die een tageplats verleent. Ontwerpaktiviteiten van stagiaires worden dus wél auteurstechteli jk bescherma wanneer daarbij geen sprake is van een arbeidsovereenkomst.

$V I .3 .3$

werken warop auteursrecht bestat

- Art. 10 lid 1 , onder de opsomming in dit artikel wan de werken letterkunde, wetenschap en kunst zijn voor de architekt van belang:

sub 6 - teken-, schilder-, bouw- en beelahowwerken. Iithografiëen, graveer-en andere plaatwerken: 
sub 8 - ontwerpen. schetsen en plastische werken, betrekkelijk tot de bouwkunde, de ararijkskunde etc.

De rangsehiking van de bouwwerken en ontwerpen onder het begrip kunst makt duidelijk dat daaraan ook een

kunstzinnige warde moet kunnen worden toegekend. Het zou dan ook komekwenter zijn geweest om in sub 8 van boukunst te speken in plat van bouwkunde. Rosenboom ziet hierin de arnwijzing dat de wetgever alle bouwerken, al of niet met artistieke kenmerken, onder de wet heeft willen brengen (* 7). Snijders is het daarmee geheel oneens (*8).

Deze kunswarde is juist een anleiding voor veel misverstanden en diskussies, vooral ook omdat de anwezigheid ervan de maker auteursrechten verschaft, terwijl de kunstwarde van het objekt zelf voor het auteursrecht niet van belang is. Of lets mool of lelijk is, de eathetiache warde, blijft buiten diskusisie. On uit deze impasse te geraken heeft men veelal zijn heil gezocht in het begrip originaliteit, de afwijking ten opzichte van wat gangbat is en als een persoonlijke uitdrukkingsvorm van de maker kan worden gezien (*9). De Beaufort voegt daaraan nog het element "nieuw" toe (* 10$)$ en stelt tevens het kunstzinnig element als bepalend, immers, andere werken van intellectuele arbeid vallen onder patenten en

octrooimogelijkheden. Het beperkende "nieuw" is goed bruikbaar in kombinatie met de uitsiuiting van het gangbare en geijkte; dat zal altija een herhaling zijn en dus niet nieuw of oorspronkelijk.

ook in de jurisprudentie heeft originaliteit en persoonlijke uitdrukking een rol gespeeld: de kleuterschool te Krabbendijke (* 1l) en de varkensmeststal Maarheeze (* 12). Het zal echter duidelijk zijn dat niet elk bouwwerk "automatisch" onder de auteurswet valt, de hiervoor genoemde kriteria zijn daarvoor bepalend.

De tekeningen en schetsen, maquettes en dergelijke var de architekt vallen onder de wetelijke bescherming, tenzij de architekt die rechter heeft overgedragen. Dat komt nogal eens voor. Vooral grote opdrachtgevers wensen te kunnen beschikken over plattegronden en doorsneden in verband met de exploitatie en het onderhoud van het bouwwerk. zolang darvan geen misbrulk wordt gemakt voor het plegen van ingrepen in de konceptie buiten de architekt om kan daar in cedelijkheid geen bezwar tegen worden gemakt.

VI. 3.4

het openbar maken en verveelvoudigen

- Art. 12 lid $\mathbb{1}$, onder de openbaarmaking van een werk van letterkunde, wetenschap of kunst wordt mede verstaan:

1 "de penbarmaking van eene verveelvoudiging van 
het geheel of een gedeelte van het werk"

2 "de verbreiding van het geheel of een gedeelte van een werk of van eene verveelvowiging daran, zoolang het niet in druk is verschenen

(vosropenbarmaking)" .

- Art. 13, onder verveelvoudiging van een werk van letterkunde, wetenschap of kunst wordt mede verstaan: "iedere geheele of gedeeltelijke bewerking of nabootsing in gewijzigde vorm, welke niet als nieuw oorspronkelijk werk moet worden aangemerkt".

Rosenboom ziet in de toevoeging "in gewijzigde vorm enz." een wettelijke uitbreiding van het begrip verveelvoudiging (* 13). Het gebouwde is daardoor een verveelvoudiging van het bouwplan zij het in andere vorm. Dit spoort met de definitie zoals die is vervat in de uitbreiding van de Berner Conventie d.d. 1908 (zie VI.1). Daarmee wordt de ontwerper beschermd, wiens plan zonder zijn voorkennis wordt uitgevoerd, omdat het zowel een openbaarmaking als een verveelvoudiging betreft. Openbaarmaking houdt in de eerste presentatie, verveelvoudiging alle keren daarna.

Beide wetsartikelen $z i j n$ bedoeld om plagiaat te bestrijden. Nu komt plagiaat betrekkelijk weinig voor. De cauge célebre van het woerdense raadhuis is al eerder gereleveerd. Samen met het geplagieerde bouwplan van selfridges in Londen en een nagebootste deur aan de Weesperzijde in Amsterdam heeft het bijgedragen aan de tatstandkoming van de bescherming via de Auteurswet van bouwkunstig werk. Een ander salliant geval werd à raison van f. $350,-$ in der minne geschikt (* 14).

Thans is plagiaat in de bouwkunst minder aktueel dan ooit. standaardisatie van bouwprogramma's en detailleringen dragen dartoe bij. Originaliteit is, zo al aanwezig, zo op het projekt toegesneden dat kopieren bijna onmogelijk is geworden.

De praktijkontwikkelingen in de woningbouw kurnen wel a anleiding zijn tot gchendingen van het auteurscecht op het stuk van verveelvoudiging. Het kont nl. vaak voor dat woningbouwplannen worden ontwikkeld door het uitvoerend bouwbedrije dat daarbilj een architekt in de arm neemt voor het ontwerp. Soms tracht de aannemer ook in andere gevallen hetzelfide ontwerp gebouwd te krijgen zonder medeweten wan de architekt. In 1985 liep daarover een kortgeding van Rb Almelo 18.9 .85 warbij de architekt stillegging wan de bouw vorderde (niet gepubliceerd). De architekt verloor ondat de rechter matschappelijke motieven zwarder liet wegen dan het auteursrecht (hoge onkosten bij gtilleggen van de bouw). Een schadevergoeding was niet gevorderd.

Het verdient derhalve aanbeveling om het auteurarecht van de architekt duidelijk te reserveren in de overeenkomst aannemer-architekt. 
- Art. 14, dit artikel verbiedt het verveelvoudigen door middel van fotogratie of film van bouwkunstige werken. Een bekend geval is het geschil rond de aulainterieurs van de $T H$ te Delft (* 15). Fotograferen en publiceren zonder voorkennis en toesteming van de architekt komt veel vook. Vooral reklamedrukwerk van bouwaterialen .d. Vertoont dit soort inbreuken nogal eens, meestal ontbreekt de nam van de auteur van dit gebouw. Architekten zijn daar zelf mede schuld aan. Er wordt zelden geprotesteerd, integendeel, men voelt zich vaak gevleid en lat zich deze publiciteit gaarne welgevallen, zeker als het werk al enige bekendheid geniet.

VI. 4

Overige bepalingen van de auteurswet

VI. 4.1

openbaarmaking en verveelvoudiging

De artikelen $15 \mathrm{t} / \mathrm{m} 23$ bevatten een serie beperkingen op het auteursrecht die slechts in zeer bijzondere gevallen voor de architekt van belang zijn, met uitzondering van de volgende artikelen:

IV. 4.2

beperkingen

- Art. 18, houdt een beperking in van het auteursrecht op fotografische openbaarmaking of verveelvoudiging "indien het werk daarbij niet de hoofdvoorstelling vormt en de ververlvoudiging door hare grootte of door de werkwijze, volgens welke zij vervaardigd is, een duidelijk verschil vertoont met het oorspronkelijke werk, en zich"wat bouwwerken betreft tot het uitwendige daarvan bepaalt"

Het uitwendige mag dus onder voorwarden, worden wervel voudigd, het inwendige niet.

- Art. 23, staat de eigenaar van een bouwwerk toe on het objekt zonder toesterming van de auteurscechthebbende, als tenminste niet anders is overengekomen, in een katalogus ten toon te stellen mits met het oogmerk het te verkopen.

Makelaarsadvertenties met foto's van het objekt $z i j n$ dechalve toegestaan.

$V I .4 .3$

het "droit moral" of persoonlijkheidsrecht

- Art. 25 , bevat de persoonlijkheidsrechten van de maker, t.w.: 
1. De maker van een werk heeft, zelfs nadat hij ijn auteursrecht heeft overgedragen, de volgende rechten:

a het recht $z$ ich te verzetten tegen de openbaarmaking van het werk onder een andere naam dan de zijne alsmede tegen het aanbrengen van enige wijziging in de benaming van het werk of in de anduiding van de maker, voor zover deze op of in het werk voorkomen, dan wel in verband daarmede $z i j n$ openbaar gemaakt;

$b$ het recht $z i c h$ te verzetten tegen elke andere wijziging in het werk, tenzij deze wijziging van zodanige aard is, dat het verzet zou zijn in strijd met de redelijkheid;

$c$ het recht $z$ ich te verzetten tegen elke misvorming, verminking of andere aantasting van het werk, welke nadeel zou kunnen toebrengen aan de eer of de naam van de maker of an zijn waarde in deze hoedanigheid.

2 De onder $a$, $b$ en $c$ genoemde rechten komen na het overlijden van de maker tot aan het vervallen van het ateursrecht toe aan de door de maker bij uiterste willsbeschikking of bij codicil aangewezene.

3 Van de rechten onder a en b genoemd kan afatand worden gedaan voor zover het wijzigingen in het werk of in de benaming daarvan betreft.

4 Heeft de maker van het werk het auteursrecht overgedragen dan blijft hij bevoegd in het werk zodanige wijzigingen aan te brengen als hem naar de regels van het matschappelijk verkeer te goeder trouw vrijstaan. Zolang het auteursrecht voortduurt komt gelijke bevoegdheid toe aan de door de maker bij uiterste wilsbeschikking of codicil a angewezene, als redelijkerwijs annemelijk is, dat ook de maker die wijzigingen zou hebben goedgekeurd" .

Dit artikel is van groot belang zowel voor de architekt als voor de kultuur. Het kan een rem vormen op het verloren gaan van belangrijke architektonische werken.

Het droit moral uit de Berner conventie is niet overdraagbaar. Zollang de maker in leven is, is zijn toestemming voor a antasting van het werk vereist, zelfs als hij zijn overige rechten heeft overgedragen. Op dit recht worden vele inbreuken gemakt, met opzet of te goeder trouw. Veel eigenaren van gebouwen denken dat zij het volledig beschikkingsrecht daarover bezitten en "de architekt toch immers is betadd". Bij verkoop van parden met architektonische waarde wordt het verzwegen, uit vrees dat de koper hierin een belemmering zal zien van zijn plannen. Soms negeert de nieuwe eigenaar het recht willens en wetens ondat hij liever met zijn "eigen" architekt werkt. Formeel kan de architekt zijn medewerking aan 
wijziging van zijn werk ontzeggen, max dat blijkt in de praktijk weinig effektief. Rechtsprekende instanties hebben doorgaans meer oog voor het algemeen belang dan voor het geeatelijk eigendom van de maker. Aantasting kan trouwens ook plaatsuinden als door a an- of bijboussels het karakter van het oorspronkelijk werk verloren gaat.

Niet alleen aantasting van het werk wordt in art. 25 geregeld, in feite is de naam en de wardigheid van de maker in 't geding. Jurisprudentie over art. 25 is er weinig. Het kleuterschooltje te Krabbedijke (*16). Dakkapelien Nieuwegein (* 17), herbouw pand (* 18). Dat is merkwardig genoeg omdat het artikel de beste garanties inhoudt voor handhaving van de rechten van de architekt. Wellicht speelt de angat om als "lastig" te worden aangemerkt daarbij een rol.

Zonderland sluit zich bij Snijders aan (*19) in zijn veroordeling van architekten die via art. 25 Aw trachten hun wensen te vervullen. Wat met "wensen" wordt bedoeld wordt in het midden gelaten mar is wel essentieel. De Auteurswet is er niet om opdrachtgevers aan architekten voor het leven, en daarna, te binden. Wel om originele produkten van de geest te doen respekteren. De huidige Gedragsregelen van het Architektenregister staan inbreuk op oude relaties met opdrachtgevers trouwens toe (wijziging 1985) wanneer het niet handelt om een reeds gegeven opdracht. Dat betekent dat het spanningsveld tussen de "oude" konceptie en de noodzakelijke aanpassing door de beide architekten in goed overleg moet worden geregeld, binnen de grenzen der redelijkheid. Om dit te bereiken zijn voldoende middelen voorhanden al of niet gebaseerd op de goede trouw.

VI. 4.4

handhaving van het auteurstecht-strafbepalingen

- Art. 26, wanneer een bouwwerk door twee of meer acchitekten is ontworpen en hun afzonderlijke inbreng niet is te identificeren kan, tenzij anders overeengekomen, de handhaving van het auteursrecht door ieder van hen geschieden.

- Art. 28 lid 1 , regelt de rechten van de maker bij wederrechtelijk gebruik van zijn produkt bij tentoonstellingen e.d. Het is goed erop te wijzen dat het tentoonstellen van ontwerpen en tekeningen een openbaarmaking $\mathrm{c} . \mathrm{g}$. verveelvoudiging is in de $z$ in van de wet, en derhalve door de maker moet worden toegestaan met door hem te bepalen voorwarden. 
- Art. 28 lid 4 , anti-plagiant artikel. De gerechtigde kan de rechter doen gelasten dat door de gedaagae dusdanige wijzigingen an het door hem gebouwde worden aangebracht dat de gelijkenis met het origineel wordt teniet gedaan.

Zuiver plagiat is in de bouwkunst een bijna onbekend verschijnsel zoals reeds eerder is gesteld, het is voor de architekt dan ook van weinig warde.

- Art. $31 \mathrm{t} / \mathrm{m} 34$, strafsancties. Nast de kans op civielrechtelijke procedures loopt degeen die inbreuk makt ook nog een kans op een strafrechtelijke vervolging. Sommige inbreuken worden als misdrijf gekwalificeerd, andere als overtredingt. De

boetebedragen belopen f.10.000, - tot f.25.000, , de gevangenisstraffen ten hoogste zes maanden.

VI. 4.5

duur van het auteursecht

- Art. 37 lid 1, het auteursrecht vervalt na verloop van 50 jaar na overlijden wan maker, te rekenen vanaf 1 januari van het jaar van overlijalen van de maker.

- Art. 37 lid 2, bij gemeenschappelijk auteursrecht geldt hetzelfde, de langstlevende maker is daarbij maatgevend.

Echter: de persoonlijkheidsrechten moeten bij codicil worden overgedragen aan rechtsopvolgers om te gelden tot aan de vervaltermijn van 50 jaar na de dood van de maker (art. 25 lid 2 AW).

VI. 5

Het auteursrecht en de Algemene Regelen voor de honorering van de architekt en de verdere rechtsverhouding tusisen. opdrachtgever en architekt (AR 71), c.q.SR 87 .

Wanneer de architektenopdracht plats vindt onder de bepalingen van de $A R$ is er nog sprake van een nadere stipulering van hetgeen in de Auteurswet is bepala.

- Art. 45 AR"71 1id 1, benadrukt art. 12 AW voor wat betreft de openbaarmaking en verveelvoudiging en breidt dit uit met het begrip "verwezenijuking". Sommige juristen zien in de realisatie van het bouwwerk een openbaarmaking (de Beaufort), anderen weer niet, zodat deze toewoeging een eind makt aan een mogelijke diskussie. 
- Art. 45 AR'71 lid 2a, houdt een beperking in van het auteurstecht voor de architekt wardoor het voor de opdrachtgever mogelijk wordt om een ontwerp te (doen) uitvoeren na vootijajge beëindiging van de overeenkomst opdrachtgever-architekt. Is dit het geval na wanpresteren van de architekt, art. 40 Iid 2 AR'71, dan is dit alleszins redelijk. Iets anders ligt het wanneer de architekt de opdracht tot direktievoeren neerlegt "zonder gegronde redenen" . Weliswar kan over het al of niet gegrond zijn van deze weigering via het AIB worden geprocedeerd, maar gezien de tijd die daarmee is gemoeid, is het annemelijk, dat de bouw dan al zo ver is voortgeschreden dat er redelijkerwijs geen weg terug meer is. In wezen sanctioneert art. 45 lid $2 \mathrm{~b} A R^{\prime} 71$ deze gang van zaken, al is kontrole over de uitwoering via art. 5 lid 3 AR gewarborgd en de honorering voor deze arbeid via art. 7 lid 3 AR. Het is echter volstrekt illusoir dat van een dergelijk "toezien" en de honorering iets terecht komt in de dan volledig verstoorde verhouding met de opdrachtgever. Wat bovendien te doen bij afwijking van het ontwerp? De gang naar het AIB Iijkt niet zinvol, bovendien is het niet uitgesloten dat het projekt in-aanbouw van eigenaar wisselt en daarmee ook de opdrachtgever. Dan staat alleen nog de gang naar de rechter open. Een weinig bevredigend artikel dat bovendien uitgaat van de veronderstelling dat "de" opdracht aan de architekt per definitie bok die van de direktievoering onvat. Dat is niet altijd het geval. Sommige opdrachten eindigen bij de a anbesteding of eerder.

De architekt doet er goed aan teneinde zijn auteursrechten te kunnen handhaven:

a de bestedingsstukken zo kompleet gereed te maken dat over zijn architektonisch koncept geen diskussies kunnen ontstaan;

b bij zijn onvolledige opdracht een desnoods symbolisch honorarium te bedingen dat hem legitimeert om bij de direktievaering door anderen op het werk te kunnen toezien dat zijn koncept wordt gevolgd.

Het onder a genoemde komt door aanbestedingshast nogal eens in het gedrang, terwijl bij de uitvoering, afhankelijk van externe omstandigheden en bedreigde budgetten, nogal eens vrijelijk geparafraseerd wordt op het plan wan de architekt. 
- Art. 45 lid $2 \mathrm{C} \mathrm{AR}^{\prime} 71$, hetzelfde geval als voren, echter nu met een warschijnlijk niet verstoorde relatie opdrachtgever-architekt (overmacht). Men moet annemen dat in dat geval beiden gediend zijn met een minnelijke schikking waaruit geen problemen zullen voortvloeien.

- Art. 46 AR'71, het aanbrengen van de naan van de maker op het werk konform art. 4 Aw en het recht om die bij verminking van het werk, daarvan te verwijderen.

Aan dit artikel is gekoppeld het recht om het in-en exterieur te fotograferen en te publiceren. Een recht dat niet door elke opdrachtgever zondermeer wordt aanvard, voor sommige werken omiat zij ofwel strategische-dan wel bedrijfstechnische aspekten kennen die de opdrachtgever niet graag in de publiciteit ziet. Veelal wordt in zulke gevallen dit recht in de opdrachtformulering terzijde gesteld, dan wel een nadere regeling getroffen. 
VI.6

NOTENLIJST

1 Cremers Zonderland

2 mr. L. Wichers Hoth

3 mr. H.L. de Beaufort

4 rar. L. Wichers Hoeth

5 mr. W. Wicherg Hoeth

6 prof.me.W.L. Haardt

7 mi. E.H.P. Rosenboom

8 F.W.G.J.Snijders van Wissenkerke

9 mr. L. Wichers Hoeth

$10 \mathrm{mr}$. H.L. de Beaufort

11 Rb. Middelburg

12 Hot Den Bosch

13 mr. E.H.P. Rosenboom

14 Het Hooge Dak

15 Rb. Rotterdam

16 Rb. Middelburg

$17 \mathrm{Rb}$. Utrecht

18 Rb. Middelburg

19 Cremers zonderland
- Bouwrecht/Auteursrecht VI, no. 1 bIz. 3

- BR 1967 - Het auteursrecht van de architekt

- Bouwkundig Weekblad 1912 blz. 598

- BR 1967 bIz. 596

- BR 1967 blz. 598

- BR 1976 blz. 123

- Botwkundig Weekblad 1925 blz. 375 -

Het auteursrecht van den architekt

- Het auteurscecht in Nederland 1913

- BR 1967 blz. 597

- Bouwkundig Weekblad 1912 - Het auteursrecht op werken der Bouwkunst

- 14-01-1970 NJ 1970-297

- 15-06-1965 NJ $1968-396$ BR 1969 blz. 106

- Bouwkundig Weekblad 1925 blz. 385 -

Het auteursicht van den architekt

- Bouwkundig Weekblad 1924 blz. 155

- 18-10-1966-NJ $1968 \mathrm{nr} .415$

- 14-01-1977

- 18-10-1977

- 14-02-1977

- Bouwrecht VI blz. 11 
KONKLUSIE

Terugziende op de thans bijna 150-jarige ontwikkeling van de architekt als vrije en onafhankelijke beroepsbeoefenaar kan men zich niet aan de indruk onttrekken dat deze door de tijden heen moeite heeft gehad om zijn positie in het matschappelijk en juridisch krachtenspel zelf te bepalen. $\mathrm{Hij}$ is veeleer een speelbal van de omstandigheden wartegen hij geen weerstand kan bieden en wartegen hij zich ook zelden teweerstelt.

Dat vindt zijn oorzaak in het ambivalente van zijn beroep: enerzijds de gedrevenheid als kunstenaar om te scheppen, anderzijds de volstrekte afhankelijkheid van een veelheid aan niet-beinvloedbare faktoren. Dat geldt niet alleen voor zijn beroep, ook voor zijn schepping-als-zodanig. Het spanningsveld tussen vorm, techniek, funktie en kosten, is enerzijds een uitalaging, anderzijds een noodlot. De vorm, de architektonische gedachte, zal valk in meer of mindere mate koncessies eisen van de overige bepalende faktoren. De bereidheid van de opdrachtgever tot het doen van deze koncessies hangt af van diens kulturele instelling. De een neemt enig ongerief of hogere kosten voor lief in ruil voor een specimen van architektuur, de ander is daartoe minder geneigd.

Deze tweeledigheid bepaalt ook het karakter van de architekt, sommigen zullen eerder dan anderen bereid zijn tot koncessies aan het architektonische uitgangspunt dan anderen. In kringen van het metier scoren in waardering doorgaans diegenen het hoogst die zich het minst toegeeflijk betonen ten aanzien van de belemmerende elementen in deze gebonden kunst.

Helaas komt doorgaans een dergelijke insteliling de nam van de architekten niet ten goede.

De kulturele wardering van de opdrachtgever blijkt voorts geen konstante: zij is konjunktuur-gevoelig. In tijden van recessie wordt de architekt eerder en harder angesproken op de niet-kulturele facetten van zijn opdracht.

De architekt is in zijn verschijningsvorm dus het evenbeeld van de architektonische problematiek. Het skala varieert van ontwerpend-ambachtsman tot de ara de materie-ontstegen fantasierijk-vormgever, dienar wan de principaal of de muze. Nog te weinig blijken opdrachtgevers zich bewust van het grote belang van een zorgvuldige architektenkeuze: immers men kiest zich een schepper van een leefomgeving, de vermaterialisering van de nog niet gekonkretiseerde gedachte, met alle aankleve van dien. 
Deze kernproblematiek blijkt van alle tijden. Jacob van Campen raakte er in de 17 e euw door in onmin met de vroede vaderen van de stad Amsterdam. Aldo van Eyck met zijn opdrachtgevers van het Burgerweeshuis in de tegenwoordige tija.

Het blijkt dat konfikten tusgen architekten en hun opdrachtgevers vijwel altijd voortkomen uit een tekortschieten van de architekt in de faktoren techniek en kosten die nu juist de architektuur bij uitstek tot gebonden kunst maken.

woch zijn het valk de meest bekritiseerde architektuurultingen die als kultuurdragers worden gezien. ook in dat opzicht past dus slechts een relativerend oordeel.

Een niet-onbelangrijk facet van het architektenkontrakt is het verschil in opvatting van de jurist enerzijds en de vormgever anderzijds. Het juridisch denken verloopt langs strakke lijnen en patronen die door de jurisprudentie in het gareel worden gehouden. Kleine afwijkingen in de interpretatie leiden tot grote opwinding en felle diskussies. Voor het architektonisch denken is dat hoogst verbazend. De goede architekt grijpt nooit naar geijkte oplosisingen, accepteert "patronen" hoogstens als onontkoombaar doch zal er op een of andere wijze zodanig vorm an geven dat een maximum a an eigenheid ontstaat. De konfrontatie van de beide denkwijzen openbaart zich in de valk herhalde diskussie over de uitsluiting van de esthetische warde als toetsingsnorm voor de architektenprestatie. Het is symptomatisch dat deze uitsluiting te vinden is in een van de oudste standaardkontrakten: de AR'22, en ook in alle opvolgers van deze regeling. De hiervoor geschetste variabiliteit van het aandeel van de esthetica in de architektemprestatie en de subjektiviteit in de toetsing nopen tot de uitsluiting van dit kriterium.

Het arbitraal beding in het architektenkontrakt is al zeer oud. Reeds sinds 1904 makt deze deel uit van de regelingen voor de rechtsverhouding opdrachtgever-architekt. Wellicht heeft de eerder geschetste esthetische beoordelingsproblematiek darbij toch nog enige invloed gehad.

Uit het onderzoek is komen vast te staan dat een goede beroepsopleiding essentieel is voor matschappelijke acceptatie. De ontwikkelingen in de dertiger jaren zijn darvoor het bewijs. Ook het omgekeerde is echter het geval. Een te zeer afwijken door de beroepsopleiding van de kern van het métier n.l. het bouwen als synthese tussen worm, techniek, funktie en kosten, heeft een werwoestend effekt op het imago van het beroep, had maatschappelijke acceptatie en in het verlengde darvan: op de interpretatie van de rechtspositie. Dat leert de gang van zaken rond 1970. De fatale neiging van architekten om hun eigen funktoneren steeds weer ter diskussie te stellen buiten de eigen kring doet het matschappelijk onbegrip nog verder 
De kontraktuele relatie tussen architekt en opdrachtgever heeft vrijwel geen wijziging ondergaan binnen de termijn van het onderzoek. Tot 1987 vigeren er Algemene Regelen in een gedaante die vrijwel identiek is a an die van 1932. slechts op ondergeschikte punten wijken de regelen af. Gezien de relatie tussen matschappelijke ontwikkelingen en de juridische begrenzingen in kontraktuele relaties daarvan, kan dit hoogst merkwaardig worden genoemd. Immers, de daartoe strekkende hoofdstukken uit dit proefschrift schetsen een beeld van kontinue matschappelijke verandering in status van en wardering voor de architekt. Een dergelijke afwijking van de voor wrijwel alle wettelijke en niet-wettelijke regelingen geldende "juridische cyclus", kan alleen worden verklaard uit het klaarblijkelijk feit dat bf massale ontwijking van de standaard-kontraktuele bepalingen door opdrachtgevers en/of architekten heeft platsgevonden, of de grenzen van de regeling zo ruim zijn gesteld dat binnen dat kader een heel skala van kontraktvorming kon plaatsvinden.

Dat laatste is zeker niet het geval, zodat de eerste veronderstelling resteert: beide kontrakten interpreteerden de regel al naargelang de situatie.

uiteindelijk leidde dat o.a. tot het verschijnsel deelopdrachten. Een gevolg van deze ontwikkeling zijn de ekonomische problemen van de huidige architektenstand. De koppeling van de rechtsverhouding en de honorering geraakte uit haar evenwicht.

Bij de volledige opdracht wordt veelal van de architekt een grotere prestatie verlangd dan door de honorering wordt gerechtvaardigd. Daarbij blijkt de reële omvang van deze te leveren prestatie vak pas op een tijdstip dat ver na de totstandkoming van het kontrakt 1 igt.

De deelopdracht dwingt voorts tot ontleding van dat wat een perfekte synthese dient te zijn.

Deze inperking van het architektenkontrakt ontneemt de beroepsbeoefenaar de voor zijn beroepservaring essentile terugkoppeling nat de praktijk van de ultvoering. Deze beperking in omvang van de opdracht heeft dan ook mede geleid tot een sterke inkrimping van de omvang van het gemiddelde architektenbureau in de latste decennia. De diskontinuiteiten in de bedrijfsvoering als gevolg van de ekonomische teruggang heeft daar uiteraard ook het nodige toe bijgedragen.

De buitenkantraktuele rechtspositie van de architekt kent binnen de onderzoeksperiode evenmin schokkende ontwikkelingen. Waar sprake is van een verbetering komt deze uitermate traag en arzelend tot stand. Een aantal facetten kan zulks verduidelijken:

onrechtmatige daad.

De ontwikkeling rond de onrechtmatige daad gat vrijwel 
geheel aan de architekt voorbij. Het denken over dit leerstuk ontwikkelt zich in juridische zin vanaf 1899 als vervolg op Scholten's dissertatile "Schadevergoeding buiten overeenkomst en onrechtmatige daad" rond de kernbegrippen onrechtmatigheid ( $w .0$. de zorgvuldigheidsnorm), causaliteit (verband tussen voorval en achade), schuld (verhouding Bchuld en cisiko), en schade (materieel/imaterieel). Deze ontwikkeling loopt derhalve in de tijd parallel a ontstalan van het fenomeen architekt, matr heeft op diens juridische positie geen enkele invloed.

Beroepsbescherming.

Het mag hoogst opmerkelijk heten dat er sinds Bruynzeel" s steiling 20 uit zijn dissertatie in 1900 betreffende de wenselijkheid van enigerlei titel- of beroepsbescherming voor de architekt, het 86 jaar heeft moeten duren aleer daarvan in Nederland sprake was. Deze kwam eerst tot stand nadat er van supra-nationale zijde druk werd uitgeoefend.

Gedurende deze gehele periode bleken politieke ontwikkelingen sterker dan een matschappelijke behoefte tot erkenning en bescherming van dragers van de architektonische kultuut.

Auteursrecht.

Zelfs de geestelijk eigendom van de architekt is tot de dertiger jaren vogelvrij geweest. Liep Nederland al niet voorop in zorg voor het geestelijk erfgoed (de Auteurswet kwam hier te lande eerst tot stand in 1912 , als een van de latate landen in Europa), de angst om door de kultuur in de vrije beschikking over het onroerend goed te worden beknot sloot tot 1931 wijzigingen aan bouwwerken uit van auteursrechtelijke bescherming.

Tot op de huidige dag heeft deze wettellike regeling, die naast bescherming van het geestelijk eigendom ook nog een niet onbelangrijke kultuur-konserverende werking heeft, nog steeds vrijwel alleen matschappelijke betekenis, omdat zij noopt tat overleg met de architekt. Juridisch wordt zij helaas nog steed sterk ondergewardeerd, ook door beropogenoten. Hiex is duidelijk sprake van een wisselwerking.

Het blijkt derhalve dat er in de onderzoeksperiode vijwel niet gesproken kan worden van een wisselwerking tussen de matachappelijke ontwikkeling van de architekt in het vrije beroep en de kontraktuele relatie tot zijn opdrachtgever, noch op grond van de standaardkontrakten noch op grond van buitenkontraktuele wettelijke regelingen. 
Geraadpleegde standaardwerken, de tijdschriftenliteratuur is vermeld in hoofdstuk I.1.2.

Cremers/Zonderland

Wijngaarden, prof. mr. M.A. van

Asser/Rutten III

Asser/van der Grinten II

Hofman/Abas

Werf, mr. H.G. van der

Wi jngaarden van/Zeben van

M.L. Andree Wiltens

Meijknecht, mr. P.A.M.

Schut, prof. mr. G.H.A.

Schut, prof. mr. G.H.A.

Praag, mr. ir. M.M.

Adriaansens, prof. mr. C.A.

Hartkamp, mr. A.S.

Hugenholtz/Heemskerk

Bloembergen, prof. mr. A.R.

Randag, mr. B.H.G.J.

Sanders, prof. mr. P.

Verkade/Spoor

Adriaansens c.s.

Bruynzeel, mr. J.P.

Winzer

Heideloff
Bouwrecht

Hoofistukken

Bouwrecht

Gouda Quint 1969

Verbintenissenrecht $T_{j}$. Willink 1979

De Rechtspersoon Tj. Willink 1980

Het Nederlandse

Verbintenissenrecht $\mathbb{P j}$. Willink 1977

Redelijkheid en

Billijkheid in het

Contractenrecht

Gouda Quint 1982

Compendium

Bijzondere

Overeenkomsten

Enige opnerkingen

over $1645 \mathrm{BW}$

Kennismaking met

het Burgerlijk

Procesrecht

Rechtshandeling ,

Overeenkomst en

Verbintenis

Onrechtmatige Daad

Bouwrecht

Eigen schuld van

de Architekt

Kluwer

dissertatie

utrecht

1982

1882

Tj. Willink 1980

Tj. Willink 1980

Tj. Willink 1981

Schel tema-

Holkema 1966

DUP

1986

Compendium $\mathrm{v} / \mathrm{h}$

Vermogenisrecht NBW Kluwer

Hoofdilinen van het

Nederlands Proces-

Recht.

VUGA

1982

Vertegenwoordiging

Jurisprudentie op

de $A R$

Tj. Willink 1981

Het nieuwe

Arbitragerecht

Auteursrecht

Prakt i jkboek

Onroerend Goed

De Rechtspositie

van de Architect

diss.

BNA

1986

Klluwer

1987

Riluwer

1985

Kluwer

1987

Die Deutache

Bruderschaften des

Mittelalters

Die Bauhltte des

Mittelalters in

Deutschland
Leiden

1900

Giessen

1859

Nurnberg 1844 
vilet, mej. M. van

Wal, ir. J.J. van der

$$
\text { Reyn, G. van }
$$

Hendrix, mr. A.J.M.

Creveld, mr. I. van

Cremers, dr. W.A.M.

Lennep, mr. D.E. van

Louvet, Albert

Klinkhamer, Jacob F.

Kruyt/Twi jnstra

Hendriks, prof. dr. ing.

Hendriks, prof. dr. ing.

Knapper en Mc Alley

BNA
Het Hoogheemraad-

schap van de Lekdi jk-bovendams

diss.

Utrecht $\quad 1961$

De Ekonomische

ontwikkelingen in

het Bouwbedrijf in

Nederland

Waltman 1940

Geschiedkundige

Beschrijuinge van

de Stad Rotterdam

Het Recht en de

Architect

Bouwheer en

Architect

Architecten- en

Aannemersrecht

Civielrechtelijke

Verantwoordel $i j k h e i d$

van Architecten in

Ingenieurs

1'Art d'Architecture

et la Profession

d'Archi tecte

Gedenkschrift van

de Kon. Akademie

Polytechnische

School te Delft

De interne

organisatie van

het architecten-

bureau in Ned.

De veranderende

Bouwopglave

Een keerpunt in de

produktie

De architect in

de jaren 80

(rapport)

Begintermen

Beroepsui toefening

(rapport)
1889

Waltman 1906

Parijs

ongedateerd

Bolle

Tj. Willink 1927

Van Mantgem 1926

Samson $\quad 1973$

Moussault 1984

DUP $\quad 1978$

1983

1985 
Verkorte Inhoud:

DE RECHTSPOSITIE VAN DE ARCHITEKT 1850 - 1985

"Een onderzoek naar de relatie tussen ontwikkelingen in de matschappelijke positie en de rechtspositie van de architekt .

Promator: prof, mr. C.A.Adriaansens.

Hoofdstuk I - Inleiding

In dit hoofdstuk komen aan de orde de uitgangspunten van

het onderzoek, zoals:

- de probleemstelling

- de onderzoeksmethodiek

- het tijdvak van onderzoek.

- de historische ontwikkelingen rond aannemer en architekt tot aan ca. 1850

- het rechtskarakter van de architektenopdracht.

De probleemstelling:

deze studie dient ertoe om na te gaan hoe de matschappelijke ontwikkeling van de architekt, in de gedaante van de zelfstandige beroepsbeoefenaar, zich heeft voltrokken en hoe dat juridisch is vertaald. Derhalve, of de regeling van de rechtspositie van de van de architekt, in zoverre al aanwezig, gelijke tred heeft gehouden met de matschappeIijke aspekten van zijn becoepsuitoefening.

Na 1850 ontstond gaandeweg de architekt zoals men die thans kent. Het is een langzame ontwikkeling die in hoofdzaak voortkwam uit de aannemerij, of één van de ambachten. Maar ook anderen, niet ambachtelijk geschoold, waagden zich wel aan het ontwerpen van gebouwen.

Als methode van onderzoek is gekozen voor een analyse van de bouwkundige- en juridische vakliteratuur ná 1850 . angevuld met bronnenstudie standaardwerken uit de onderzoeksperiode.

Als tijdwak van onderzoek is de periode tussen 1850 en 1985 genomen ondat juist in die periode de spanning tussen matschappelijke en juridische ontwikkelingen ontstond. Het tijdvak is opgesplitst in twee trajekten: 1850 - 1940 en 1946 - 1985. Dit vanwege het ontbreken van de normale rechtsorde gedurende de oorlogstijd en het grote verschil in matschappelijke en ekonomische omstandigheden tuasen de vóor- en na-oorlogise periode. 
Teneinde een goed beeld te krijgen van de matschappelijke situatie is in het eerste hoofdstuk tevens de ontwikkeling geschetst van de eerstbekende bouwaktiviteiten tot aan het begin van de feitelijke onderzoeksperiode.

In deze tijd ontstonden de eerste organisaties op het gebied van het bouwen, zoals de Bauhuetten en de Gilden en kwam het ook tot hun verval. De opkomst van de aannemerij in zijn thuidige hoedanigheid begint inmers, na de afschafing van de Gilden, ten tijde van de Bataafse Republiek. Deze omschakeling heeft grote gevalgen gehad voor de ordening van de uitvoering van bouwwerken.

Eerst rond 1850 ontstond een woor ons herkenbare aannemer, terwijl eigenlijk rond 1900 pas van een enigsins evenwichtige situatie kon worden gesproken. Ook de rechtspositie wan de aannemer makt in die tijd dus een ontwikkeling door. "Architekten"hebben daar een grote col in gespeeld.

Ienslotte wordt uiteengezet welke interpretaties en kwalifikaties er ontstonden rond het rechtskarakter van de overeenkomst tussen opdrachtgever en architekt. De verwarring dienaangaande sproot voort uit de onduidelijkheid die aanvankelijk het architektenberoep kenmerkte. Pas in de dertiger jacen is men redelijk eenstemmig in de kwalifikatie van "het verrichten van enkele diensten".

Hoofdstuk II

De ontwikkeling van de matschappelijke positie van architekt, aannemer en derden tussen 1850 en 1940 .

In dit hoofdstuk komen an de orde de matachappelijke problemen die kenmerkend zijn voor de drie partijen die deel uitmaken van de overeenkomsten tot het ontwikkelen van plannen voor, en uitvoeren van, bouwwerken.

De bescherming van de titel of het beroep van de architekt makt al ginds het einde van de 19 e euw een punt van diskusile uit in kringen van juristen. Daarbij hebben uiteraard de beroepsbeoefenaren zich al spoedig aangesloten. Tevergeets: in deze onderzoeksperiode komt er ondanks dat geen wettelijke regeling tot stand.

Voor het matschappelijk aanzien, en daarmee de rechtspositie, is de kwaliteit van de beroepsopleiding van zeer grote betekenis. ook die kende slechts een langzame ontwikkeling, ondanks, of liever, dankzij de inspanningen 
van velen. Vooral professor Eugen Gugel heeft een grote bijdrage geleverd aan de kwaliteitswerbetering van het beroep van de architekt, zoals die in de loop van de jaren dertig gestalte kreeg.

Het ontstar wan architekten-organisatie heeft eveneens bijgedragen aan matschappelijke erkenning. De aanvankelijke tweespalt tussen de Matschappij tot Bevordering der Bouwkunst enerzijas en de Bond van Nederlandse Architekten anderzijas heeft slechts kort geduurd: na een tiental jaren werden $z i j$ weer vereend en zijn dat gebleven.

De feitelijke tegenvoeter van de architekt, de alnnemer evalueerde in deze periode van een verdachte tegenvoeter tot een bonafide kontraktpartner. Ook daar droegen verbeterde opleidingen voor het bouwvak het hunne toe bij. ook hier zijn het mede de architekten geweest die de stoot dartoe hebben gegeven.

De derde partij in het bouwgebeuren, de opdrachtgever. bleef wat in de schaduw. De architekt bepalde in feite diens standpunt in de uitleg van het annemings-kontrakt. De enige zeer herkenbare opdrachtgever was de overheid: "Waterstaat". De diskussie over de rechtspositie van de aannemer ging dan ook voornamelijk tussen hen beiden. Niet zozeer belangrijk qua matschappelijke omvang dan wel. qua kultureel-architektonisch aspekt was de roomskatholieke kerk in deze periode. De acceptatie van thet roomskatholieke volksdeel als evenwardig an de overige godsdienstig georiënteerde bevolkingsgroepen, deed een hausse ontstaan in de sakrale architektuur die nog steeds hat stempel. drukt op het silhouet van stad en dorp. Pas veel later zou er zelts sprake zijn van een "eigen" rechtsverhouding voor kerkbouw-opdrachten aan architekten.

Hoofdstuk III

Ontwikkeling van de rechtspositie wan de architekt t. $0 . v$. de annemer, opdrachtgever en derden tussen 1850 en 1940.

Behandeld worden achtereenvolgens de kontraktuele en de buitenkontraktuele rechtspositie van de architekt. voorts wordt aandacht geschonken aan de relatie van de architekt, als vertegenwoordiger van de opdrachtgever, met de annemer in samenhang met diens rechtspositie.

Reeds vanaf 1884 deed $z i c h$ de behoefte gevoelen an vormen van standaardvoorwarden voor de kontraktuele relatie architekt - opdrachtgever. Veelal gebruikte men 
aanvankelijk honorariumtabellen zoals die in het buitenland werden gehanteerd. Het heeft tot 1904 geduurd eer er van een nederlandse "Tabel" sprake was.

Eerst zeer langzam is de juridische erkenning daarvan gemeengoed geworden. De moelichting bij deze tabel evalueerde uiteindelijk tot een afgeronde regeling van de rechtsverhouding opdrachtgever - architekt met de Algemene Regelen van 1922 .

De latere versies van deze Regelen zijn in hoofdzaak werfijningen die in essentie niet van haar voorganger verschillen. Vooral de AR 1932 bleek een vast uitgangspunt voor tientallen jaren.

Aan de diskussie over de juridische kwalifikatie van de architekten-opdracht, die zich vooral rond 1920 toespitste, wordt de nodige aandacht geschonken.

De vertegenwoordigingsbevoegdheid van de architekt heeft, hoe kan het ook anders war een goede regeling tot de twintiger jaren ontbreekt, vaak aanleiding gegeven tot strijdvragen. Tevens deden zich daarbij de eerste aariprakelijkheidsvragen voor met betrekking tot de architekt.

De buiten-kontraktuele rechtspositie van de architekt gaf in deze periode weinig aanleiding tot bijzondere aandacht. Er deden zich enkele gevallen voor van aansprakelijkheid uit onrechtmatige daad die echter meer op het terrein van de aannemer lagen dan van de architekt.

Voortgang op het gebied van titel- of beroepsbescherming werd, ondanks alle pogingen daartoe, niet gemakt.

Belangrijk zijn de" ontwikkelingen op het gebied van het Auteurscecht. In hoofdstuk VI wordt daaraan speciale aandacht geschonken.

Architekten hebben zich, uit hoofde van hun verantwoordelijkheid als spli in het bouwproces, zeer beijverd om de wankele rechtspositie van de aannemer ten tijde van het einde van de vorige euw, te verbeteren. Dat leidde in 1907 tot het instellen van de Raad van Arbitrage, warmee, alhoewel nog niet algemeen als zodanig erkend, toch een aanzet werd gegeven tot objektieve geschillenbeslechting.

In 1911 kwam een koncept-AAV tot stand door samenwerking van architekten, ingenieurs en aannemers die, althans voor de burgerbouw tot rechtvaardiger werkomstandigheden voor de a annemer leidde. 
Vanaf de twintiger jaren onstond het fenomeen

"eigenbouwer", de annemer die voor eigen rekening en

risiko voor de markt bouwt. Gezien de gevestigde

matschappelijke positie van de architekt ontsitonden

daardoor bouwkunstige konfliktsituaties die sommige architekten trachtten op te lossen door bijzondere kontraktuele konstrukties. De tijd bleek daarvoor echter nog niet rijp.

Hoofdstuk IV

De architekt in het matschappelijk krachtenspel 1945-1985

In de na-oorlogse situatie ontstond een ekonomische groei, die, aanvankelijk gereguleerd, allengs vrijer funktioneerde en een aanleiding vormde voor een onstuimige expansie van de bouwaktiviteiten. De kentering daarvan kwam in de jaren zeventig op gang en had voor de bouwwereld grote gevolgen. Eenzelfde cyclus makte ook de architekt en zijn bureau door.

Het algemeen ekonomisch herstel na 1946 en de konsekwenties. daarvan voor het bouwen, werden gekenmerkt door een sterke regulering van overheidswege. Men was bevreesd dat er na het inlopen van de achterstand een even grote werkloosheid zou ontstaan als viak voor de mweede wereldoorlog het geval was geweest. Bovendien bestond er een tekort aan materialen.

Aan deze taestand kwam in de jaren zestig langzaam een einde; de ekonomie ontwikkelde $z$ ich in snel tempo. Vooral de explosieve groei van de dienstensektor deed de architekt goed. Veel bureaus groeiden uit tot ware ondernemingen. Gezien echter de juist in die jaren ontluikende diskusisie rond het funktioneren van de architekt werd de vraag gesteld of hij wat dat betreft wel aan de verwachtingen beantwoordde.

De invloed van een wat overtrokken kritiek van de beroepsbeoefenars zelf op hun eigen rol in thet bouwproces, werkte verwarring bij de niet-ingewijden in de hand. Deze zelfkritiek kreeg bovendien nog een forse injektie uit de kringen van de architekten-opleidingen. ook de steeds terugkerende diskussie over de ontwerp-architektenwet van 1949 lat zien dat de matschappelijke positie van de architekt niet algemeen in positieve zin wordt ervaren. Toen het bouw-ekonomisch beeld in de loop van de zeventiger jaren verslechterde, betekende dat een desastreuze kentering in de matschappelijke positie van de architekt. 
Het leidde op den duur niet alleen tot een versmippering van het architektenbureau als organisatie, doch ook van de opdracht-zélf: de deeloparacht wordt gemeengoed.

De opsplitsing van de opdracht, die een synthese dient te uijn van vorm, funktie en konstruktie, houdt in dat in feite wordt teruggekeerd nat opdrachtsituaties uit de beginperiode van dit onderzoek.

Hoofdstuk W

De juridische implikaties van het verschuivend matschappelijk beeld.

In dit hoofdstuk wordt geanalyseerd welke verschillen er zijn te onderkennen in: de opeenvolgende standaardregelingen. Enige aandacht wordt geschonken aan de nieuwste regelling, hoewel deze ten tijde van dit onderzoek nog geen rechtsgeldigheid bezat.

Verder worden de belangrijkste juridische diskussiepunten belicht, alsmede de meest gebruikelijke vormen van geschillenbeslechting tusen opdrachtgever en architekt. Enige beschouwingen over praktijkontwikkelingen in de toekomst kompleteren dilt hoofdstuk.

Uitgaande van de Algemene Regelen van 1932, die ook vanaf 1946 aanvankelijk nog van kracht zijn, wordt een analyse gegeven per artikel van de opeenvolgende regelingen. De verschillen blijken slechts van ondergeschikte aard.

Reeds kort na de invoering van de AR 1964 is het werk aan een geheel nieuwe standaardregeling van start gegaan. De geest des tijds eiste een nieuwe juridische aanpak in relatie met de zich wijzigende matschappelijke omstandigheden van de architekt.

Pas in 1987, dug na de onderzoeksperiode, is de zogenaamde Standaardregeling Rechtsverhouding oparachtgever-Architekt 1987 " kortweg genaand de SR 87 , van kracht geworden voor de partikuliere opdrachtgever. Het Rijk en de grote woningbouwkopels zijn echter niet van zins zich te konformeren an de énzijdige wan kracht-verklaring van de BNA. De daaruit voortvloeiende onderhandelingen duren nog voort.

Aan de hand van de standardregelingen en de jurisprudentie wordt voorts ingegaan op de vertegenwoordigings-bevoegdheid van de architekt uit kontrakt in de verschillende fasen van de opdracht, dus van planontwikkeling tot en met de wituoring. 
De honorering van de architekt wordt bezlen op die punten die soms aanleiding vormen voor geschillen.

Wanprestatie met betrekking tot de architektenovereenkonst: is aan de orde bij overschrijding van bouwsomlimieten. Een analyse is verricht ten aanzien van de daarop betrekking hebbende jurisprudentie.

De ansprakelijkheid van de architekt en de daarbij behorende exoneratieproblematiek, alsmede de geschillenbeslechting makt deel uit van behandeling. Gezien de te verwachten ontwikkelingen, zowel in de bouwpraktijk als in de wetgeving vanwege het in antocht zijnde Nieuw Burgerlijk Wetboek, zijn aan beide onderwerpen beschouwingen gewijd.

Hoofdstuk VI

Auteursrecht en de Bouwkunst.

Het auteursrecht makt deel uit van de buiten-kontraktuele rechtspositie van de architekt. Hoewel reeds in 1912 de Auteurswet in Nederland van kracht werd, werd de bescherming van de geestelijke eigendom van de architekt eerst in 1931 afgerond, toen ook aantasting van reeds gemakt werk onder de wet werd begrepen.

De bouwkunst neemt in het Auteursrecht een bijzondere plaats in. Immers voor vrijwel alle overige kunstuitingen geldt dat de exploitatie van de geestelijke eigendom een grote rol speelt. Dat is bij de bouwkunst nauwelijks het geval.

Van veel grotere importantie is voor de bouwkunst het persoonlijkheidsrecht (droit moral). Aantasting of verminking van bouwwerken, of wat daartoe behoort, zonder enige voorkennis van de ontwerper, komt veelvuldig voor en doet ernstig afbreuk aan de architektonische warde van de gebouwde ongeving. Veelal komen dergelijke ingrepen op ondeskundige wijze tot stand. De geschiedenis van thet ateurgrecht leert, dat het bouwkundig oeuvre vooral tegen deze aantasting een moeizaam bevochten rechtsbescherming kent.

Aan de artikelen van de wet die voor de bouwkunst van belang $z i j n$ wordt speciale aandacht geschonken. 


\section{Konklusie}

Terugziende op de thans bijna 150-jarige ontwikkeling van de architekt als vrije- en onathankelijke beroepsbeoefenaar kan men zich niet aan de indruk onttrekken dat deze door de tijden heen moeite heeft gehad om zijn positie in het maatschappelijk en juridisch krachtenspel zélf te bepalen. Veeleer is hij een speelbal van de omstandigheden waartegen hij geen weerstand kan bieden en wartegen hij zich ook zelden teweerstelt.

Dat vindt $z i j n$ oorzaak in het ambivalente van het beroep: enerzijds de gedrevenheid als kunstenaar om te scheppen, anderzijas de afhankelijkheid van een veelheid aan nietbeinvloedbare faktoren.

De kulturele wardering van de opdrachtgever blijkt voorts geen konstante: zij is konjunktuur-gevoelig.

De kwaliteit van de beroepsopleiding blijkt van groot bellang voor de matschappelijke positie van de architekt. Rond 1930 werkt dit positief, rond 1970 is het omgekeerde het geval. Juist dan blijkt, dat een te zeer afwijken van de kern van het métier, n.1. het bouwen als synthese tussen vorm, techniek, funktie en kosten, een verwoestend effekt heeft op het imago van het beroep.

De kontraktuele relatie tussen opdrachtgever en architekt heeft in de onderzoeksperiode vrijwel geen wijziging ondergaan. Dat is een afwijking van de, voor regelingen in het algemeen geldende regel, dat $z i j$ regelmatig warden aangepast aan de zich wijzigende maatschappelijke omstandigheden, de zogenaamde "juridische cyclus".

Dit kan alleen worden verklaard uit het feit dat of een massale ontwijking door opdrachtgevers van de tandaardregels heeft plaatsgevonden, of de regels zo ruim zijn gesteld dat binnen dat kader een heel skalla van kontraktvorming kon plaatavinden.

De eindkonklusie van het onderzoek luidt, dat er in de onderzoeksperiode vrijwel niet gesproken kan worden van een wisselwerking tussen de matschappelijke ontwikkeling van de architekt in het vrije beroep en de kontraktuele relatie tot zijn opdrachtgever, noch op grond van de standaardkontrakten, noch op grond van buitenkontraktuele wettelijke regelingen. 
THE LEGAL STATUS OF THE ARCHITEKT $1850-1985$

"Research into the relation in developments between the social position and the legal status of the architekt".

Promoter: prof.mr. C.A.Adriaansens.

Chapter I - Introduction

In this chapter basic points in the area of research are raised such as:

- definition of the problem

- research methodology

- period of research

- historical developments concerning contractor and architect $c .1850$

- legal nature of the architect's contract.

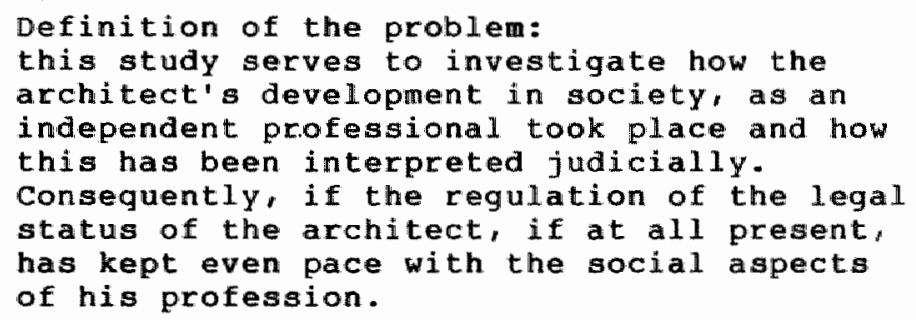

After 1850 the architect as we now know him gradually developed. It was a slow process, which found its origin mainly in the construction business or one of the crafts. But others also ventured into designing buildings.

As a method of research an analysis of architectural ard juridical specialist literature from 1850 onwards has been chosen, supplemented with original research of standard works of the period of research.

This research covers the period 1850 - 1985 because it was precisely in this period that tension arose between social. and juridical developments. This period has been divided into two parts: 1850 till 1940 and 1946 till 1985.

This is because of the lack of normal legal order during the war and the great difference with respect to social and economic conditions between the pre- and post war periods. In order to get a good idea of the social conditions, the first chapter also deals with the development of the firstknown building actiwities until the beginning of the period of research of the thesis. 
In this period the first organizations in the field of building were set up, such as the Bauhtiten and the Guilds and it was in this same period that their decilne set in. The development of the builaing construction in its present form begins after the Guilds were abolished, in the time of the Bataafse Republiek (1795 - 1806).

This change had great consequences for organizing the execution of building projects.

Not until 1850 ald a recognizable building contractor come into existence, whereas it was not until 1900 that a somewhat balanced situation arose. The legal position of the bulliding contractor experienced a development in this period.

"Architect" played an important role in this development.

Finally it is set forth what interpretations and qualifications aroge round the juridical nature of the contract between client and architect. The confusion on this subject resulted from the vagueness which initially characterized the profession of architect. It is not until the nineteen thirties that people are reasonable consistent in the juridical qualification of "carrying out of some services".

Chapter II

The development of the socilal position of architect, building contractor and third parties between 1850 - 1940 .

This chapter deals with the social problems characteristic of the three parties to the contract for the development of building plans and for the execution of buildings.

The protection of the title of the profession of the architect has been an issue since the turn of the century, in lawyers "circles.

of course the professional practitioners soon jolned the debate. Without avail: a legal arrangement is not achieved in this period of research.

For the social prestige and conseguently the legal position, the quality of professional training is of great importance. The latter, too, experienced a slow development, in spite of, or rather, thanks to the efforts of many. Eapecially professor Eugen Gugel has greatly contributed to the improvement of the quality of the profession of the architect, as it took shape in the course of the nineteen thities. 
The development of organizations of architects also contributed to social acknowledgement. The initial discord between the Matschappij tot Bevordering der Bouwkunst (Association for the Advancement of Architecture) on the one hand and the Bond van Nederlandse Architecten (Confederation of Architects) on the other lasted a short period only: after about ten years they were united again and have remained so ever since.

The actual antipode of the architect, the buliding contractor, evolved in this period from a doubtful antipode to a reliable contract party. The improved training in the building trade greatly contributed to this. However, it were the architects who gave the first impulse to this development.

The third party in the building-scene, the principal, remained very much in the background. The architect determined the latter's point of view, in interpreting the building contract. The only very recognizable principal was the State Government embodied by the Ministry responsible for hydraulic and civil engineering. The discussions about the legal status of the building contractor was chiefly conducted between these two parties. In this period the Roman Catholic Church's cultural architectural aspect was more important than its social relevance. The acceptance of Roman Catholics as equal to the other religious sections of the population, caused a boom in the sacral architecture which until this very day still leaves its mark on the skyline of town and village. Many years later it was even considered establishing a separate legal relationship for commissioning the building of churches to architects.

Chapter III

Devellopment of the legal position of the architect with respect to the building contractor, principal and third parties between 1850 and 1940 .

The contractual and non-contractual legal position of the architect are successively dealt with. Besides, attention is paid to the relation of the architect as representative of the principal with the building contractor in connection with the former's legal position.

As early as 1884 the necessity was felt for forms of standard conditions for contractual relation between architect and principal. At first schedules for fees were often used like those abroad. It was not until 1904 that a Dutch "Schedule" was introduced. 
Very slowly its juridical acknowledgement was generally accepted. The commentary accompanying this schedule eventually evolved to a complete cegulation of the legal relation between principal and architect with the Algemene Regelen (General Regulations) of 1922.

The later versions of these Regulations are mainly refinements, which in essence do not differ from their predecessors. Especially the AR 1932 appeared to be a firm basis for a few decades.

Adequate attention is paid to the discussion on juridical characterization of the architect"s contract, which culminated about 1920 .

The competence of representation of the architect has, since there 1 s no adequate regulation until the nineteen twenties, often given cause to disputes.

At the ame time the first limbility cases occur concerning the architect.

The non-contractual legal position of the architect gave little cause for special attention in this period. There were some cases of liability out of torts, which were, however, more in the domain of the building contractor than in that of the architect.

No progress in the area of title- or professional protection was made, in spite of every possible attempt.

Important are the developments in the field of copyright. In chapter IV special attention is paid to this subject.

Architects have, as responsible pivots in the building process, done their utmost to improve the insecure legal position of the contractor after the turn of the century. This led to the setting up of the Raad van Arbitrage (Council of Arbitration) in 1907, which although not generally accepted as such, nevertheless gave an impuls, to an objective conciliation of differences.

In 1911 a draft-AAV was drawn up as a result of the cooperation of architects, graduate engineers and building contractors, which led to more equitable conditions for the contractor.

In the nineteen twenties the phenomenon "eigenbouwer" came into being, the bullding contractor who builds for the market at his own risk. In the light of the established social position of the architect, building disputes arose which some architects tried to resolve by special contractual constructions. However, the time was not yet ripe for this. 
The architect in the social interplay of forces $1945-1985$

In the post-war situation an economic growth developed, which initially regulated, gradually functioned more freely and led to a turbulent expansion of building activities. The turning point came in the seventies and had great consequences for the building industry. The architect and his firm went through a similar cycle.

The general economic recovery after 1946 and its effect on the building industry were characterized by strong Government regulation. It was generally feared that after having caught up with the backlog, unemployment would be as high as just before the second world War again. In addition there was a shortage of building materials.

This situation gradually came to an end in the sixties, the economy developed at a rapid rate. Especially the explosive growth of the services industry benefited the architect. Many firms expanded into real companies. It was in these years that the architect's functioning was discussed, as the question was raised whether he came up to expectation.

The influence of a somewhat exaggerated criticism of their own role in the builaing process by architects themselves was the cause of confusion among non-experts. This selfcriticism also received a strong impuls from the architects' academies.

Also the continually recurring discussions on the Architects' Bill of 1949 shows that the social position of the architect is not generally experienced in a positive way.

When the economic situation of the building industry deteriorated in the course of the seventies, the social position of the architect deteriorated as well. Not only did this lead to a fragmentation of the architect"s firm as am organization, but also to a fragmentation of the commission itself: the fragmentation of commissions became common practice.

The splitting up of the commission, which ought to be a synthesis of form, function and construction, means a return to the situation which prevailed in the first period this research deals with. 
The judicial implications of the changing social picture

In this chapter an analysis is made of the differences in the successive standard regulations. Some attention is paid to the latest regulation, although it had not yet been implemented t the time of this research. Furthermore the most important judicial issues are discussed, as well as the most customary forms of arbitration between principal and architect. Some reflections about the practical developments in the future complete this chapter.

Taking into consideration the General Regulations (AR) of 1932, which have been in force from early 1946, an analysis is made of each article of the successive regulations. The differences appear to be of marginal $\mathbb{1}$ mportance.

Shortly after the introduction of the General Regulations (AR) of 1964, the work on the entirely new standard regulations had already begun. The spirit of the times required a new judicial approach in relation to the changing social position of the architect.

Not until 1987, so after the period of our research, did the so-called "Standard Regulation on the Legal Relations Principal - Architect 1987 " in short SR 87 take effect for the private principal. The Government and the big housing corporationg do not wish to comply with the unilaterally introduced Standard Regulations. Negotiations are still going on.

On the basis of the standard regulations and the relevant jurisprudence, attention is paid to the architect's competence of representation ensuing from the contract with regard to the various phases of the contract, so from plaming development up to and including the building.

The remuneration of the architect is examined, where it may give cauge for disputer.

Incompetent performance in relation to the architect's contract 1 raised when total building limits are exceeded. An analysis has been made with regard to the relevant Jurisprudence. The liability of the architect and the exoneration issue, as well as arbitration, are dealt with.

In view of the expected developments in the building trade a well as in legislation in connection with the introduction of the New Civil Law, both subjects have been discussed. 
Copyright and architecture.

Copyright is part of the non-contractual legal position of the architect. Although the copyright Act took effect as early as 1912, the protection of the spiritual possession of the architect was not completed before 1931 when infringement of the rights of any design of an architect became protected by 1 aw.

Architecture takes a special place in copyright. For almost all other arts the exploitation of spiritual possession plays a major role. This is hardly the case with Architecture.

of much greater importance to architecture are the personal rights (droit moral). The violation or mutilation of building designs or anything of the sort, frequently happens without any foreknowledge to the designer and derogates the architectural value from the surrounding buildings. Very often such changes are made incompetently. The history of copyright teaches us that the architectural oeuvre has acquired hard-won legal protection against such infringements.

To those articles of the law which are important to architecture special attention is given.

Chapter VII

Conclusion

Looking back at the almost 150 years of development of the architect as a free and independent professional, it must be concluded that the architect himself al ways had great difficulties to determine his position in the social and judicial interplay of forces. He is a mere plaything of circumstances which he cannot resist and consequently seldom does.

This is caused by the ambivalience of the profession: on the one hand the enthusiasm of the artist to create, on the other the dependence on numerous factors beyond his influence. The cultural appreciation of the principal appears not to be constant: it is sensitive to the economic situation. 
The quality of the professional training appears to be of great importance to the social position of the architect. About 1930 it has a positive effect, about 1970 the reverse proves to be the case. Then it appears that too great a divergence, namely building as a synthesis of form, technology, function and cost has a devastating effect on the image of the profession.

The contractual relations between principal and architect hardly underwent any change in the period of research. This is a deviation of the generally valid rule for regulations, namely that they are regularly adapted to the changing social circumstances, the so-called "judicial cycle". This can only be explained from the fact that either a massive evasion of standard regulations by principals took place, or the rules have been so freely enforced that within that framework whole range of contracts could be concl uded.

The final conclusion of this research is that in the period of research there is hardly any interaction between the social development of the architect as an independent professional and the contractual relation with his principal, neither on the grounds of the standard contracts, nor on the grounds of non-contractual legal regulations. 